\title{
Huisarts en diagnostisch centrum : toepassing van werkafspraken door huisartsen
}

Citation for published version (APA):

Beusmans, G. H. M. I. (1986). Huisarts en diagnostisch centrum : toepassing van werkafspraken door huisartsen. [, Maastricht University]. Gadet. https://doi.org/10.26481/dis.19860919gb

Document status and date:

Published: 01/01/1986

DOI:

10.26481/dis.19860919gb

Document Version:

Publisher's PDF, also known as Version of record

\section{Please check the document version of this publication:}

- A submitted manuscript is the version of the article upon submission and before peer-review. There can be important differences between the submitted version and the official published version of record.

People interested in the research are advised to contact the author for the final version of the publication, or visit the DOI to the publisher's website.

- The final author version and the galley proof are versions of the publication after peer review.

- The final published version features the final layout of the paper including the volume, issue and page numbers.

Link to publication

\footnotetext{
General rights rights.

- You may freely distribute the URL identifying the publication in the public portal. please follow below link for the End User Agreement:

www.umlib.nl/taverne-license

Take down policy

If you believe that this document breaches copyright please contact us at:

repository@maastrichtuniversity.nl

providing details and we will investigate your claim.
}

Copyright and moral rights for the publications made accessible in the public portal are retained by the authors and/or other copyright owners and it is a condition of accessing publications that users recognise and abide by the legal requirements associated with these

- Users may download and print one copy of any publication from the public portal for the purpose of private study or research.

- You may not further distribute the material or use it for any profit-making activity or commercial gain

If the publication is distributed under the terms of Article $25 \mathrm{fa}$ of the Dutch Copyright Act, indicated by the "Taverne" license above, 


\title{
HUISARTS EN DIAGNOSTISCH CENTRUM
}

\author{
Toepassing \\ van \\ Werkafspraken \\ door \\ Huisartsen
}

\begin{abstract}
PROEFSCHRIFT
ter verkrijging van de graad van doctor in de geneeskunde aan de Rijksuniversiteit Limburg te Maastricht, op gezag van de Rector Magnificus, Prof. Dr. F.I.M. Bonke, volgens het besluit van het College van Dekanen,
\end{abstract} in het openbaar te verdedigen op vrijdag, 19 september 1986 om 17.00 uur

door

George Beusmans

geboren te Noorbeek in 1944

1986

Gadet - Maastricht 
Ter nagedachtenis aan mijn vader

en als dank voor mijn moeder.

Promotor:

Prof. Dr. W. Brouwer

Referenten:

Prof. Dr. J.J.C.B. Bremer

Prof. Dr. R.A. de Melker

Prof. Dr. H. Philipsen

Prof. Dr. F. Sturmans

ISBN 90-70469-02-2

Manuscript: Mevr. T. Seegers.

Het verschijnen van dit proefschrift werd financieel mede mogelijk gemaakt door bijdragen van CIBA Farmaca, Merck, Sharpe \& Dohme-Chibret B.V., Schering Nederland B.V. en Smith, Kline \& French B.V.

(C) 1986 G. Beusmans, Maastricht.

Niets uit deze uitgave mag worden verveelvoudigd en /of openbaar gemaakt door middel van druk "fotocopie, microfilm of op welke wijze dan ook zonder voorafgaande schriftelijke toestemming van de uitgever. 
HUISARTS

EN

\section{DIAGNOSTISCH CENTRUM}

onderzoek naar de toepassing van werkafspraken door huisartsen ten aanzien van het gebruik van diagnostische faciliteiten. 


\section{Inhoudsopgave}

1.

1. 1 .

1.2

1. .3

$2 *$

$2 * 1$.

2.2 .

2.3 .

$3 *$

3.1.

3.1 .1 .

3.1 .2 .

3.2 .

$3.2 \cdot 1$.

3.2 .2 .

$3 \cdot 2 \cdot 3$.

3.2 .4 .

3.2 .5 .

4.

4.1.

4.2 .

4.3 .

$4 \cdot 3 \cdot 1$.

$4 \cdot 3 \cdot 1 \cdot 1$.

4.3.1.2.

4.3 .1 .3$.

$4.3 \cdot 2$.

$4 \cdot 3 \cdot 2 \cdot 1$.

$4 \cdot 3 \cdot 2 \cdot 2$.

$4 \cdot 3 \cdot 2 \cdot 3$.

4.4.

4.5.
INLEIDING

Pagina

Matschappelijke en beroepsmatige context 5

van het onderzoek

Het Experiment Diagnostisch Centrum Maastricht

Aanleiding tot het onderzoek

VAN PROBLEEM TOT VRAAGSTELLING

Probleem

Literaturverkenning

28

Vraagste $\mathbb{l}$ ing

INVENTARISERING

Totstandkoming van werkafspraken ten aanzien

van het gebruik van diagnostische faciliteiten

Werkafspraken vanuit het Diagnostisch Centrum

Werkafspraken in de literatuur

Factoren van invloed op de toepassing van

werkafspraken door huisartsen ten aanzien van

het gebruik van diagnostische faciliteiten

van een Diagnostisch Centrum

Inleiding

Verwijzen door huisartsen

Voorschrijfgedrag van (huis) artsen

Factoren specifiek voor de toepassing van

werkafspraken vanuit een Diagnostisch Centrum

Samenvatting en groepering van de factoren

\section{ONDERZOEKSOPZET}

Type onderzoek

Wijze van gegevensverzameling

Methoden van onderzoek

Het meten van de toepassing van de werkaf-

60

61

61

spraken

Keuze van de te meten werkafspraken

61

Scoring van de toepasing vam de werkafspraken

Perioden van gegevensverzameling

Meting van de beinvloedingsfactoren 79

Enquête

Diagnostisch Centrum samenwerken

83

de praktijk van de huisartsen

Beschrijving van de onderzoekspopulatie van

84

huisartsen

Meetniveau 
5 .

5.1 .

5.2 .

$5 \cdot 2 \cdot 1$.

5.2 .2 .

$5 \cdot 3$.

6.

6.1 .

6.2 .

6.2 .1

6.2 .2$.

$6 \cdot 3$.

6.4 .

6.5.

$6 \cdot 5 \cdot 1$.

$6 \cdot 5 \cdot 2$.

7.

7.1.

7.2 .

7.3.

8.

8.1

8. 2

9.
ONDERZOEKSRESULTATEN

Toepassing van de werkafspraken

Enquête

Inleiding

92

Enquête bevindingen

93

Interview

100

ANALYSE EN SAMENHANGEN VAN DE ONDERZOEKSRESULTATEN

Inlejding

107

Betrouwbaarheidsanalyse van de enquêtegege-

vens en samenhangen van de enquêtegegevens met de toepassing van de werkafspraken

Betrouwbaarheidsanalyse van de enquête-

107

gegevens

Samenhangen van de enquêtegegevens met de

115

toepassing van de werkafspraken

Samenhangen van de enquêtegegevens van huis-

artsen die gebruik maken van het Diagnostisch

Centrum met de enquêtegegevens van de refe-

rentiegroep van Nederlandse huisartsen

Analyse en samenhangen van de interviewgege-

vens met de toepassing van de werkafspraken

Analyse en samenhangen van de algemene gege-

vens over de hujsartsen en over de praktjjk

van de hujsartsen met de toepassing van de

werkafspraken

Samenhangen van de algemene gegevens over de

praktijk van de huisartsen met de toepassing van de werkafspraken

Samenhangen van de algemene gegevens over de

huisartsen met de toepassing van de werkafspraken

INDIVIDUELE FEEDBACK AAN DE HUISARTSEN OVER DE TOEPASS ING VAN DE WERKAFSPRAKEN

Inlej.ding

1.43

Meetgegevens

Enquểete- en interviewgegevens van de huis-

145

artsen over het geven van feedback

SAMENVATT ING EN AANBEVELINGEN

Samenvatting

156

Aanbevelingen

163

SUMMARY 
LITERATUUR

174

BIJLAGEN

184

DANKBETUIGING

189

CURRTCULUM VITAE 


\section{INLEIDING}

1.1. DE MAATSCHAPPELIJKE EN DE BEROEPSMATIGE CONTEXT VAN HET ONDERZOEK

In vele discussies het medisch handelen betreffende, wordt de laatste jaren ingegaan op het gebruik van werkafspraken in de geneeskunde en wordt de hantering hiervan bepleit. Werkafspraken zijn op vele terreinen van de geneeskunde toe te passen; ten a anzien van het anamnestisch handelen, het diagnostisch handelen, het therapeutisch handelen, de begeleiding door de arts en combinaties hiervan. Werkafspraken kunnen gelden voor één specifieke discipline binnen de gezondheidszorg, maar kunnen ook de samenwerking tussen meerdere groepen hulpverleners betreffen.

onder werkafspraken worden hier en verder in dit onderzoek verstaan, afspraken tussen huisarts(en) en specialist(en) over algemene of specifieke aangelegenheden betreffende diagnostiek en/of therapie, gericht op verbetering van de patientenzorg en/of van de samenwerking tussen huisarts(en) en specialist(en). op diverse platsen in de literatuur worden andere termen gebruikt die hetzelfde aangeven: beleidsafspraken, platiselijke protocollen en richtsnoeren.

Daarnaast kennen we de protocollen, zoals hier meestal over gesproken wordt. Onder deze protocollen worden verstaan expliciete, op wetenschappedijk onderzoek en/of langdurige kiniache ervaring gebaseerde beschrijvingen van de meest geeigenae te nemen stappen in de diagnostiek en/of therapie van de patient. In werkafspraken kan derhalve aan samenwerking meer vorn en inhoud gegeven worden. Vanuit het gezamenlijk overlieg met betrekking tot werkafspraken kunnen andere samenwerkingsvormen in gang gezet worden.

Het Central Bestur van de Landelijke Huisartsen Vereniging (L.H.V.) ziet samenwerking van hulsartsen met elkaar en met andere disciplines in de gezondheidszorg als een essentieel deel van de taken van de huisarts. Hiervan getuigen onder andere de rapporten "Hoe helpt de dokter?" van het Nederlands Huisartsen 
Genootschap (N.H.G., 1975), "Samenwerking, een inventarisatie" van de L.H.V. (L.H.V., 1982) en "Kenmerken van de huisarts" van het Universitair Huisartsen Instituut Utrecht (Van Es et al., 1983). Dit onderzoek heeft betrekking op de samenwerking van de huisarts met de specialist bij de totstandkoming van werkafspraken voor huisartsen ten aanzien van het gebruik van diagnostische faciliteiten van een Diagnostisch centrum.

Allereerst zullen we nader stilstaan bij de samenwerking van de huisarts en de specialist. Voor het begrip samenwerking bestat geen éénduidige omschrijving. Wel worden daarbij de volgende aspecten onderscheiden:

- met elkaar, met verenigde krachten werken;

- zich gezamenlijk doen gelden;

- gemeenschappelijk aan een zelfde taak arbeiden.

In deze studie zal van de latste omschrijving van samenwerking worden uitgegaan. Er is in deze sprake van een proces, een doel wordt nagestreefd en er bestaat de intentie om het proces met anderen als een geheel te doorlopen. Bij toepassing van deze omschrijving op de samenwerking van huisarts en specialist rijst onder andere de volgende vraag.

Welke beweegredenen liggen ten grondslag aan de intentie om als huisarts en specialist met elkaar samen te werken? Het is zinvol een ondergcheid te maken in:

a. Algemene beleidsmatige motieven vanuit de overheid;

b. Beweegredenen vanuit de beroepsgröep als geheel en van de individuele beroepsbeoefenaren in het bijzonder.

ad a. Algemene beleidsmatige motieven vanuit de overheid om de samenwerking huisartsen - specialisten te bevorderen.

Vanaf de zeventiger jaren wordt het overheidsbeleid gekenmerkt door een streven nar een versterking van de eerste lijn. De latste jaren wordt een gelijktijaige terugdringing van de tweede 
lijn hieraan gerelateerd.

In de Volksgezondheidsnota 1966 (Volksgezondheidsnota, 1966) wordt dit streven voor het eerst expliciet verwoord. Na de structuurnota Gezondheidszorg 1974 van de toenmalige staatssecretaris Hendriks wordt het beleid van de overheid expliciet in deze richting omgebogen.

In de Volksgezondheidsnota 1966 wordt reeds een pleidooi gehouden voor beheersing van de expanderende gezondheidszorgkosten: 'De volksgezonaheid heeft aringend behoefte aan het ontwikkelen van een doelmatig geintegreerd beleid, warbij op regionaal niveau de hoge kosten vergende voorzieningen doelmatig op elkaar afgestema worden en hun plaats krijgen binnen de gemeenschap met zo veel mogelijk behoud en inschakeling van de patienten in het gemeenschapsleven" "

De Structuurnota Gezondheidszorg 1974 (Structuurnota Gezondheidszorg, 1974) vertolkt de visie op een nieuwe structuur, die voor de gezondheidszorg noodzakelijk wordt geacht. Bovendien wordt nader aangegeven op welke wijzen er mogelijkheden tot verbetering van de gezonaheidszorg en het functioneren daarvan zijn. Als mogelijke oplossingen worden adryegeven een versterking van de eerste lijn en een gelijktijdige terugdringing van de tweede 1 ijn:

'Een verschuiving van het accent, dat nu te eenzijdig wordt gelegd op specialistische intramurale zorg, naar de extramurale zorg en nar de preventie, alsmede het creêren van geordende voorzieningen, op elkaar afgestema in geografisch beperkte gebieden en het planmatig verder ontwikkelen van het geheel der gezondheidszorg'.

Naast regionalisatie wordt eveneens echelonnering gezien als middel om te komen tot structurering van de gezondheidszorgvoorzieningen. Een echelon is een sector van de gezondheidszorg. met voorzieningen, die globaal dezelfde functionele kenmerken en gerichtheid vertonen. Het eerste echelon omvat de niet-gespecialiseerde, het tweede echelon de gespecialiseerde voorzieningen. De patient dient vrije toegang te hebben tot het eerste echelon, 
war de hulsarts de centrale plats inneemt. Het tweede echelon is alleen bereikbar door verwijzing vanuit het eerste.

Wil de hulsarts zijn centrale plaats kunnen vervullen, dan zal hij verbindingen moeten onderhouden enerzijds in het eerste echelon tussen de disciplines onderling (horizontaal communicatiekanal) en anderzijds in het tweede echelon met de specialisten (vertikaal communicatiekanaal).

In de structuurnota, basis voor het beleid in het daaropvolgend decennium, wordt met name aangegeven: "dat de communicatiekanalen tussen huisarts en specialist open en wederzijds dienen te zijn". Als voorbeeld wordt gegeven dat huisartsen gebruik moeten kunnen maken van sommige diensten in het tweede echelon en dat de specialisten bereid moeten zijn voor consultatie ook in de eerste lijn op te treden.

Vanuit dit beleid zijn als belangrijke wetten ontworpen:

- Wet Voorzieningen Gezondheidszorg, met regelingen ter bevordering van een doelmatig stelsel van voorzieningen voor gezondheidszorg.

- Wet Tarieven Gezondheidszorg, met regelingen met betrekking fot de tarieven voor de gezondheidszorg.

In 1980 verschijnt de Schets van de Eerstelijns Gezondheidszorg (E.L.G.Z.). In deze schets worden matregelen genoemd ter bevordering van de versterking van de eerste lijn. Als drie motieven voor de versterking van de eerste lijn worden jenoema:

- Het belang van zorg in de thuissituatie. De E.L.G.z. kan aansluiten op zelf- en mantelzorg.

- Het gewijzigd behoeftepatroon aan gezondheidszorg. Hoe langer hoe meer ziekten zijn chronisch van aard. Er is een toenemende vraag nar care nast cure. Een aantal ziekten wordt mede door riskant gedrag in gang gezet. Hierop dient vroegtijaig met preventie, vroege signalexing en gezondheidsvoorlichting en -opvoeding ingespeeld te worden.

- De tweedelijns gezondheidszorg vertoont een explosieve groei. 
Bij schaarse middelen dreigt interferentie met de E.L.G.Z. Het wordt noodzakelijk prioriteiten te stellen in de gezondheidszorg. Niet maximalisering, maar optimalisering dient uitgangspunt voor de gezondheidszorg te zijn.

Naast andere beleidsmatregelem ter versterking van de eerste 1ijn wordt in de Schets genoemd:

- beleid gericht op bevordering van samenwerking tussen de E.L.G.Z. en de andere gezondheidszorgsectoren, onder andere vergroting wan diagnostische magelijkheden in de E.L.G.Z. door middel van experimenten met diagnostische centra.

De Schets geeft verder de knelpunten aan, die een goed functioneren van de E.L.G.Z. in de weg staan. Knelpunten worden aangegeven op het gebied van de ondersteuning, de beleidsvoering en de uitvoering. Met name bij de knelpunten op het gebied van de uitvoering wordt angegeven, dat de taak van de E.L.G.Z. ae laatste jaren in toenemende mate is verzwaard. De behoefte aan zorg- en hulpverlening in de thuissituatie is toegenomen. Patienten worden in een vroeger stadium van hun reconvalescentieproces wit het ziekenhuis naar huis ontslagen. Daarnaast ontstaat ex een grote behoefte naar preventieve activiteiten. Het morbiditeitspatroon is eveneens indringend gewijzigd. Niet alleen zuiver somatische ziektebeelden worden aan het loket van de E.L.G.Z. gepresenteerd, maar in toenemende mate ook een scala van klachten en verschijnselen in de etiologie warvan psycho-sociale factoren een rol spelen. Adequate hulpverlening hiervoor vraagt intensieve zorg.

Daarnaast wordt als knelpunt in de uitvoering naar voren gebracht dat ex vaak onvoldoende communicatielijnen tussen de werkers in de E.L.G.Z. en de werkers in de andere echelons lopen. Als voorbeeld wordt met name gewezen op de vaak nog inadequaat verlopende samenwerking tussen huisarts en specialist. Enerzijds wordt hier gewezen op het in een aantal situaties ontbreken van gelijke patienten populaties (huisartsen werken vaak samen met specilisten van meerdere ziekenhuizen), anderzijds wordt de veronderstelling geuit, dat factoren als attitude, taakopvatting en beeldvor- 
ming over en weer tussen huisarts en specialist, hier ook vaak een rol spelen. Er is in een aantal gevallen sprake van een avergerende visie op de continuiteit van de hulpverlening voor, tijdens en na specialistische interventies.

ad b. Motieven vanuit de medische professie als geheel en van de individuele beroepsbeoefenaars in het bijzonder ter bevordering van de samenwerking huisarts - specialist.

Tegen het einde van de negentiende eeuw waren er nog vrijwel geen specialisten. In 1890 waren er 54 artsen in Nederland die zich zelf specialist noemden ( $3 \%$ van alle artsen). In de 10op van de twintigste eeuw is hun aantal sterk toegenomen. In 1910 was dit gestegen tot 462 en per 1 januari 1984 waren er 10336 specialisten tegenover 5736 huisartsen. Deze ontwikkeling stond niet op zich zelf; ze vloeide voort uit de explosieve ontwikkeling van kennis en kunde, welke ook de medische wetenschap in de twintigste eeuw doormakte. De geneeskunde ontwikkelde zich hoe langer hoe meer in de diepte, specialisatie werd steeds meer noodzake1ijk, resulterende in een toenemend aantal specialismen en deelspecialismen. Was in 1940 nog sprake van een 17 -tal specialismen, in 1985 is dit aantal gestegen tot 28. Naast de toename van de medische kennis en kunde, nam eveneens de medische consumptie toe. Het aantal aan de huisarts gepresenteerde ziekten en klachten is sinds 1945 ongeveer verdubbeld (Huygen 1977). Deze toename van zowel de kwantiteit als de ard van de gepresenteerde klachten ontstond mogelijk ten gevolge van het hoge verwachtingspatroon met betrekking tot de gezondheidszorg en een toename van 'welvaartsziekten' als gevolg van diverse matschappelijke ontwikkelingen (De Melker 1975).

De positie en functie van de huisarts ondergingen dientengevolge grote veranderingen. Kwam de patient anno 1920 nog vrijwel uitsluitend bij de huisarts, die slechts in specifieke gevallen de hulp van de specialist inriep, in 1985 is vrijwel eenieder wel eens onder behandeling van een specialist (geweest). De huisart- 
sen zijn in een toenemend aantal gevallen de hulp van de specialist gaan inroepen. In $1985 \mathrm{lag}$ het landelijk gemiddelde op circa 500 verwijskaarten per 1000 ziekenfondspatienten per jaar. De laatste jaren is dit getal gestabiliseerd en zelfs wordt enige teruggang geconstateerd.

Naast ontegenzeglijk grote voordelen brengt de toename van het aantal specialisten en van het aantal verwijzingen een aantal. risico's met zich mee, zoals:

- verdere toename van de historische scheiding tussen de ziekenhuiszorg en de thuiszorg;

- sterke daling van de directe contacten tussen huisarts en specialist in het ziekenhuis of bij patienten thuis;

- vermeerdering van het aantal 'onpersoonlijke' verwijzingen. Enerzijds worden vaak verwijskaarten gevraagd zonder consultatie van de huisarts. Ongeveer de helft van het totale aantal verwijzingen bestaat uit deze zogenaamde 'passieve' verwijzingen. De huisarts kan nauwelijks invloed op deze verwijzingen uitoefenen. Voor een groot deel betreffen dit "herhalkaarten" en 'E.H.B.O.-verwijzingen'. Anderzijds worden patienten vaak naar klinische afdelingen verwezen en niet naar individuele specialisten;

- vergroting van de kans op onzorgvuldigheid in de verwijzing en terugrapportage. Verwijsbrieven ontbreken vaak of zijn te moeilijk leesbaar. Ontslagbrieven komen vak erg laat en soms nooit;

- verschraling van de onderlinge persoonlijke communicatie over individuele hulpverlening. Vaak worden in deze bereikbaarheidsproblemen als argument naar voren gebracht;

- onvoldoende afstemming van de hulpverlening van huisarts en specialist en omgekeerd. Er is sprake van eigen zorgsystemen, warin men elkanders taal vaak helaas bijna niet meer verstaat.

- vermindering van de consultatie over en weer met beroep op ieders specifieke deskundigheid. 
De ervaring leert dat huisartsen en specialisten aan bovengenoemde $x$ isica"s matr ten dele ontsnappen. Dit ervaringsgegeven vormt een indicatie hoe groot de kloof kan worden, of mogelijk voor een deel reeds geworden is, tussen de huisartsgeneeskundigeen de specialistische hulpverlening.

Vanuit de beroepsgroepen van huisartsen en specialisten is er dan ook de laatste jaren een toenemende roep naar verbetering van de onderlinge samenwerking. In 1974 stelt van Mansvelt de vraag: 'zal de huisarts niet meer moeten worden ingeschakeld bij de ontwikkelingen, die in de geneeskunde in het ziekenhuis plaatsvinden'. Alleen bij een goede samenwerking van huisarts en specialist kan voor de patient een optimale geneeskundige zorg worden bereikt (Leerling 1979). Ook bij de specialisten groeit blijkbaar de belangstelling voor samenwerking met de huisarts, terwijl vroeger het afgrenzen van elkaars werkgebieden een dagelijkse gewoonte was (Van Es, 1985).

Daarnaast worden kritische kanttekeningen geplaatst bij deze samenwerking. Zo wordt gesteld dat 'afgezien van verandexingen in werkwijzen van huisarts en specialist men de vraag kan stellen wat de gevolgen zijn van een substitutie van de tweede- door de eerstelijns zorg. In ieder geval impliceert een verschuiving in taken een intensivering van de samenwerking huisarts - specialist en het ontwikkelen wan een gedifferentieerd stelsel van samenwerkingsvormen' (Everwijn en de Melker, 1985).

Ten aanzien van deze samenwerkingsvormen is het wenselijk samenwerkingsdoelen te bepalen. Voor de concrete hulpverlening zal de gewenste handelswijze als leidaraad kunnen functioneren.

Samenwerkingsdoelen tussen tweede- en eerstelijn kunnen algemeen bezien op een vijftal wijzen getypeerd worden (Greve, 1982):

- ontwikkelen van gezamenlijke basisfilosofie;

- gezamenlijk onderzoeken welke mogelijkheden van samenwerkingsvormen er zijn;

- verbetering van onderlinge communicatie; 
- oplossing van praktijkproblemen;

- inventarisering van knelpunten in de onderlinge samenwerking.

Bij het bepalen van de gewenste handelswijze bij het medisch handelen onderscheiat wulff (1980) drie soorten warden die als leidraad kunnen dienen:

- wat goed is voor de patient;

- wat goed is voor de gemeenschap;

- wat onze plicht is.

Bij de concrete hulpverlening aan individuele patienten is een zestal samenwerkingsvormen tussen huisarts en specialigt te onderscheiden (Jacobs e.a., 1983):

- diagnostische raadpleging;

- consultatie door huisarts van specialist;

- consultatieve verwijzing:

- verwijzing met overname van behandeling;

- verwijzing met gezamenlijke behandeling;

- consultatie van huisarts door specialist in het ziekenhuis.

Wil er verandering cq verbetering komen in de relatie huisartg specialist, in het bijzonder met betrekking tot het verwijzen, dan zal de huisarts zelf initiatieven moeten ontplooien, die gericht zijn op een versterking van het gevoel van eigenwaarde, op een open en directe communicatie met de specialist en op het komen tot regels (Nijhuis, 1981). Betere vormen van communicatie en samenwerking tussen huisarts en specialist zouden bevorderdi en gerealiseerd kunnen worden door, vanuit goede persoonlijke contacten, ontstane ideeën en plannen in realiteit om te zetten (Pop en Keijsers, 1985). Ook de specialist kan door de communicatie met de huisarts te verbeteren en door samen werkafspraken te maken, er zijnerzijds vanuit het ziekenhuis aan meewerken, de eerstelijn te versterken en de kwaliteit van de zorg te verbeteren (Heckman, 1974).

Het opstellen van werkafspraken zou kunnen inhouden het maken van afspraken over de taken en verantwoordelijkheden bij de behandeling van veel voorkomende aandoeningen, die zowel eerste- alo 
tweedelijns aspecten hebben (Beek e.a., 1984). Hierbij zullen huisartsen en specialisten bereid moeten zijn om, met erkenning van elkaars mogelijkheden, gezamenlijk tot werkafspraken te komen, die ook wederzijds kunnen worden getoetst. Deze samenwerking kan op platiselijk niveau beginnen tussen een specialist en enkele huisartsen (Caspari, 1985).

Volgeng anderen zal de samenwerking tussen huisarts en specialist veel verder kunmen gaan. Door Duursma (1981) wordt een model van samenwerking tussen huisarts en specialist voorgesteld, gebaseerd op de vorming van verzorgingseenheden in de polikliniek en de kiniek.

Op een antal plaatsen zijn bepaalde samenwerkingsvormen reeds in gang gezet en is hiex ervaring mee opgedaan. Zo vond een zeer intensieve vorm van samenwerking tussen huisarts en specialist plaats rond het ziekenhuis Bethesda in Hoggeveen. Deze samenwerking werd geëvalueerd en beschreven door onderzoekers van het Nederlands Huisartsen Instituut (N.H.I., 1982). Deze samenwerking was als volgt gestructureerd. Door de ziekenhuisdirectie was aan de gebruikmaking van laboratorium- en röntgenfaciliteiten de eis verbonden dat de huisartsen zich zouden organiseren. Iedere huisarts die van deze faciliteiten wilde profiteren, diende tot dit organisatorisch verband toe te treden. Onderhandelingen over gebruikscondities zouden dan met een delegatie van huisartsen gevoerd kunnen worden en afspraken zouden in principe de gehele groep binden. Door de huisartsen werd aan deze wens voldaan door oprichting van het "hulsartsenberaad" als equivalent van de mediache staf van het ziekenhuis. Het formeel overleg tussen huisartsen en specialisten vond plaats in het formeel overlegorgaan tussen dit huisartsenberaad en de medische staf. Met dit overleg werd beoogd de samenwerking en wisselwerking tussen eerste- en tweede lijn te bevorderen. Daarbij werd gestreefd naar duldelijkheid van ieders rol en verantwoordelijkheid en gewaakt voor rolvervaging. Huisartsen en specialisten in Hoogeveen probeerden aldus te komen tot een vorm van consultatieve geneeskunde, waarbij de huisarts in tamelijk vergaande mate verantwoordelijk bleef voor wat er, ook in de tweede lijn, met de patient 
gebeurde en de specialist bereid was zich in de eerste plats op te stellen als "consulent' voor de huisarts. Van de speciallist werd in feite gevraagd, dat hij, uiteraard met behoud van $z i j n$ professionele verantwoordelijkheid, waar mogelijk alleen die vragen beantwoordt, die de huisarts hem voorlegt waarbij hij probeert de patient zo snel mogelijk weer terug over te aragen aan de huisarts. De huisarts van zijn kant verplichtte zich om de specialist tot een dergelijke handelswijze in stat te stellen door het angeven van een duidelijke vraag en door een gerichte verwijzing. Na enige jaren werd evenwel de samenwerking in het overlegorgaan door de huisartsen opgeschort. De belangrijkste oorzaak hiervoor was te vinden in problemen rondom de taakafbakening tussen huisarts en specialist. Op vele terreinen claimden zowel huisarts als specialist de eerst verantwoordelijke te zijn, wiens beslissing uiteindelijk moest prevaleren.

ondat de specialisten in loondienst waren van het ziekenhuis hebben in de betreffende samenwerking, financiele problemen waarschijnlijk geen rol gespeeld. Eveneens was men over het algemeen gaarne bereid om de extra tijd, die samenwerken nu eenmal kost, te investeren (Swinkels en Dopheide, 1982).

In het gezondheidscentrum withuis te Venlo werd concrete ervaring met samenwerking opgedaan in een intensieve jarenlange samenwerking tussen huisartsen en internisten in de vorm van geregelde consultatie (Van der Grinten, 1981). In Mastricht werd als experiment een tweedaagse bijeenkomst tussen huisartsen en specialisten georganiseerd met het doel nieuwe wegen voor samenwerking te ontsluiten (Keijsers en de Koning Gans, 1983). Van deze vormen van samenwerking werd verslag gedaan. Ongetwijfeld zijn 'in stilte' op diverse platsen vele andere vormen van samenwerking in gang gezet. Er zal echter nog de nodige samenspraak tussen huisarts en specialist noodzakelijk zijn. Immers er bestaan op een aantal punten nog grote meningsverschilien wat betreft de onderlinge taakverdeling tussen huisartsen en specialisten. De rol die huisartisen en specialisten zichzelf en elkaar toekennen is verre van congruent (Beek e.a., 1985). 
Ter verbetering yan de samenwerking huisarts - specialist is onderzoek wenselijk. Dit onderzoek dient onder andere gericht te zijn op de beeldvorming bij huisartsen van de door de specialisten geleverde zorg en op de knelpunten in de samenwerking tussen huisarts en apeclalist (Kolkman en van der Voort, 1985). De veronderstelling is gewettigd, dat de knelpunten in deze met name liggen op het gebied van de informatie-uitwisseling en communicatie over patienten (Swinkels en Lodewick, 1985).

In de Schets van de eerstelijnsgezondheidszorg werd aan (experimenten met) diagnostische centra een rol bij de bevordering van de samenwerking huisarts - specialist toebedacht. Twee experimenten kregen gestalte. Eén in het ziekenhuis oudenrijn te Utrecht en één in het ziekenhuis sint Annadal te Mastricht. Bij de opening van het Experiment Diagnostisch Centrum Oudenrijn wera met nadruk gesteld, dat de betekenis van dit experiment niet is gelegen in het vergroten van de diagnostische mogelijkheden voor de huisarts, mar in het bevorderen van het samenspel tussen huisarts en specialist (De Melker, 1979).

Vanuit het Experiment Diagnostisch Centrum Maastricht (Pop en Kerkhof 1984) wera een aantal nieuwe samenwerkingsvormen tussen huisartsen en specialisten in gang gezet, zoals:

- uitbreiding van de diagnostische faciliteiten voor de huisarts, met onder andere endoscopieën en echografisch onderzoek

- gexamenlijk door huisarts en specialist maken van werkafspraken voor diagnostisch onderzoek door de huisarte

- mogelijkheid tot het consulteren van de specialist

- structurering overaracht gegevens/documentatie bij verwijzing huisarts - specialist

- gezamenlijke consensus bijeenkomsten met betrekking tot het diagnostisch en therapeutisch handelen van huisarts en speciaist

- informatieverstrekking aan huisarts en specialist via een informatie-bulletin

- gezamenlijk consult huisarts - patient - specialist in de huisartspraktijk. 
Samenvattend kan gesteld worden:

- van diverse kanten beseft men de noodzaak de samenwerking huisarts - specialist te verbeteren;

- op diverse plaatsen wordt dit uitgeprobeerd;

- een van deze plaatsen is het Experiment Diagnostisch Centrum te Maastricht.

\subsection{HET EXPERIMENT DIAGNOST ISCH CENTRUM TE MAASTRICHT (E.D.C.)}

In het jaar 1974 werd door de toemalige centrale Raad voor de Volksgezonaheid het rapport "Diagnostische Centra" gepubliceerd (Centrale Rad voor de Volksgezondheid: het rapport Diagnostisch Centrum, 1974). In dit rapport adviseerde de Raad met én of meer experimenten te exploreren in hoeverre en onder welke voorwarden diagnostische centra ondersteuning zouden kunnen bileden aan de huisartsgeneeskundige zorg.

Het toenmalige Ministerie van Volksgezondheid en Milieuhygiene reageerde positief op het advies van de Raad en vond twee ziekenhuizen - het ziekenhuis Oudenrijn te utrecht en het ziekenhuis Sint Annadal te Mastricht - bereid tot het uitvoeren van een Experiment Diagnostisch Centrum, zoals door de Raad aangegeven. Beide experimenten zouden vier jaar duren. Als uitgangspunt diende de volgende omschrijving van een Diagnostisch centrum:

'Een functionele integratie van diagnostighe voorzieningen van een ziekenhuis ten behoeve van huisartsen door middel van een organisatievorm, waardoor een betere samenwerking en taakverdeling tussen huisartsen en specialisten, een meer doeltreffend en efficiënt gebruik van de voorzieningen, alsmede een verbetering van kwaliteit en dienstverlening van de huisartsenzorg gerealiseerd kan worden' (Centrale Raad voor de Volksgezondheid: het rapport Diagnostisch Centrum, 1974).

Bij de anwijzing van het ziekenhuis sint Annadal te Mastricht heeft onder andere een rol gespeeld, dat: 
- Sint Annadal als het enige ziekenhuis in Masitricht een rayon $\operatorname{van} 150.000$ inwoners verzorgt.

- Het Medisch Regional Centrum (M.R.C.) toen reeds geruime tija functioneerde als regional overlegorgaan op het terrein van de gezondhelasorg.

- De faculteit der geneeskunde van de Rijksuniversiteit Limburg met had aandacht voor de relatie eerste- tweedelijn geacht werd te kunnen bijdragen zowel an de uitvoering als de evaluatie van het experiment.

Door het Ministerie werd het wenselijk geacht het M.R.C. in te schakelen als intermediair orgaan tussen practiserende huisartsen, ziekenhuis Sint Annadal en de Faculteit de Geneeskunde. De door het M.R.C. Ingestelde beleidsgroep Experiment Diagnostisch Centrum kwam in 1978 met een ramplan "Experiment Diagnostisch Centrum Maastricht' (E.D.C.M.). Als doelstellingen van het E.D.C.M. werden hierin aangegeven:

- "Nagaan in welke mate en op welke wijze door huisartsen gebruik wordt gemakt van laboratorium-, röntgen- en andere faciliteiten in het ziekenhuis Sint Annadal.

- Nagaan in hoeverre een meer doeltreffend en doelmatig gebruik is te realiseren van:

* de thans ter beschikking staande diagnostische faciliteiten

- de nog ter beschikking te stellen diagnostische faciliteiten.

- Nagaan in hoeverre en onder welke voorwarden introductie van het consultatieprincipe realiseerbaar en doelmatig te noemen i.s."

Het ramplan verkireeg de insteming van het departement van Volksgezondheid en Milieuhygiene, het ziekenhuis Sint Annadal en de huisartsen van de platselijke Huisartsenvereniging Maastricht en Onstreken. In 1979 kon het E.D.C.M. beginnen voor de vastgestelde looptijd van vier jaar.

Schematisch weergegeven vertoonde de organisatiestructuur van het E.C.D.M. het navolgende beeld (zie schema 1.1.). 
SCHEMA 1.1.

Organisatiestructuur Experiment

Diagnogtisch

Centrum Mastricht. De betrokken instanties en hun onderlinge relaties.*

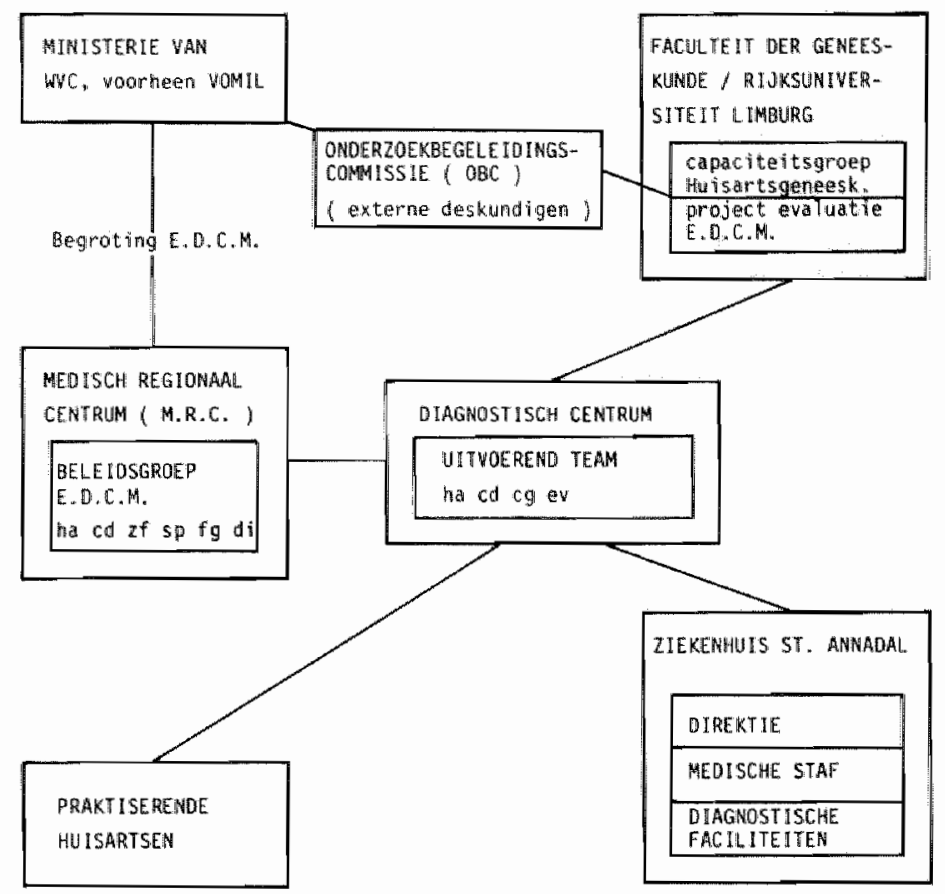

TOELICHT ING GEORUIKTE_AFKORTIMGEN :

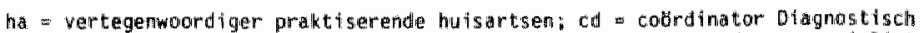

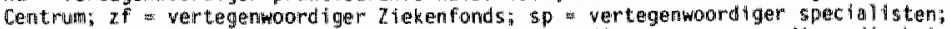

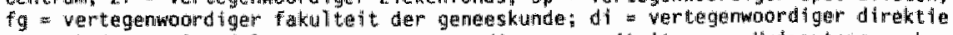

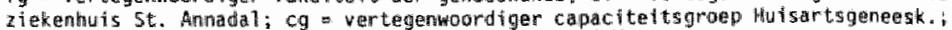
ew = vertegenwoomdiger projektgroep
}

* Overgenomen uit het rapport "Diagnostisch Centrum Masstricht Eindrapportage" (1983).

Alle huisartsen van Mastricht en naste ongeving konden participeren aan het Diagnostisch Centrum. Het aantal huisartsen-participanten bedroeg bij de start van het E.D.C.M. in 1979, 67, werkzaam in 57 praktijken. Daarvan waren 43 huisartsen werkzaam in de stad Maastricht. In figuur 1.1 . is weergegeven de situering van de huisartsenpraktijken in Maastricht en omgeving. 

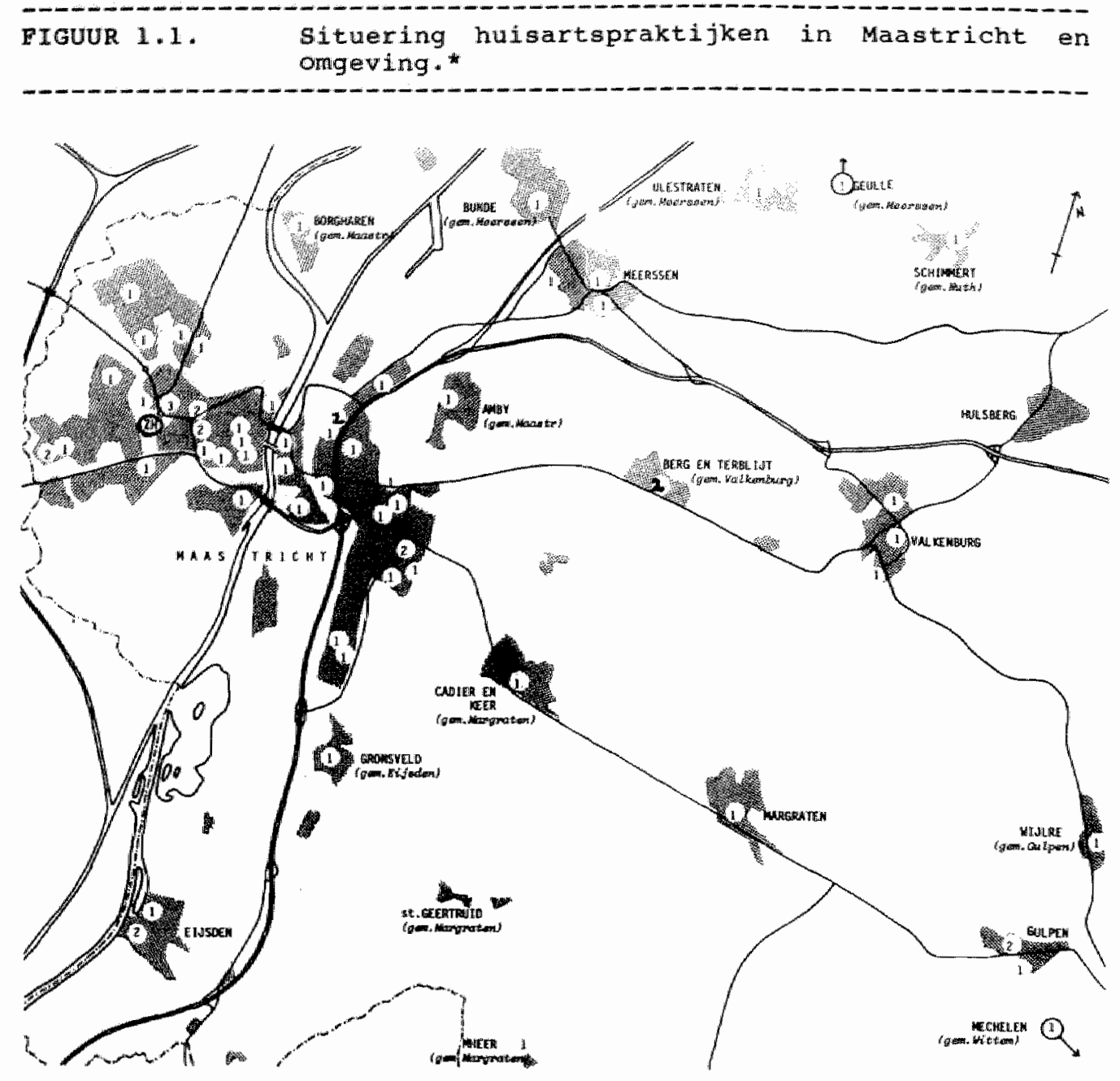

Toelfchting bij de plattegrond:

peil 1atum : 1-1-1983

$\mathrm{ZH}=\mathrm{z}$ lekenhuis St. Annadal (E.D.C.)

1 =huisarts-solist

2 =gezondheidscentrum of associatie met 2 huisartsen

3 =gezondheidscentrum met 3 huisartsen

- Overgenomen uit het rapport "Diagnostisch Centrum Maastricht Eindrapportage" (1983). 
Zoals aangegeven was een belangrijke doelstelling bij de opzet van het Diagnostisch Centrum: nagaan in hoeverre een meer doeltreffend en doelmatig gebruik is te realiseren var de in het ziekenhuis beschikbare diagnostische voorzieningen voor de huisarts. Irrelevante aanvragen dienden zoveel mogelijk voorkomen te worden. De vraag kwam naar voren op welke wijze bovengenoemde doelstelling in de praktijk gebracht en bereikt zou kunnen worden. Immers het was geen sinecure vast te stellen op welke indicaties aanvragen al dan niet zinvol waren. In de praktijk betekende dit immers, dat de onderzoeksaanvragen tegen de achtergrond van de indicaties op hun relevantie beoordeeld moesten worden. Er werd besloten voor bepaalde onderzoeksaanvraagcategorieën werkafspraken te hanteren waarin aangegeven zou worden voor welke indicaties de onderzoeksaanvragen zinvol waren.

Werkafspraken voor diagnostische onderzoekaanvragen.

In de looptijd van het E.D.C.M. werden zo werkafspraken voor een achttal onderzoeksaanvraagcategorieën ingevoerd (zie schema 1.2$.$) .$

SCHEMA 1.2 .

Overzicht van onderzoeksaanvraagcategorieën voor werkafspraken, welke in de looptijd van het E.D.C.M. werden ingevoerd.

A. Radiodiagnostische onderwerpen:

- onderzoek van de thorax

- onderzoek van de maagduodenumregio

- onderzoek van de lumbosacrale wervelkolom

- mamografie

B. Onderwerpen ten aanzien van klinisch-chemische diagnostiek

- leverfunctie-onderzoek

- schildklierfunctie-onderzoek

C. Electrocardiografie (ECG)

D. Endoscopisch onderzoek van het mag-darmkanaal.

Als criteria voor de keuze van de onderzoeksanvraagcategorieän golden met name: 
- het belang van het diagnostisch onderzoek voor het huisartsgeneeskundig handelen;

- de frequentie van vookomen van de aanvragen voor dit onderzoek:

- de mogelijkheid om het diagnostisch handelen voor een bepaald onderzoek te verbeteren.

De acht werkafspraken werden telkenmale volgens eenzelfde proceaure samengesteld. Stelselmatig werden een vijftal fasen doorlopen. Samengevat was deze samenstellingsprocedure als volgt:

- fase 1: registratie, inventarisatie en analyse van alle aanvraagformulieren van gekozen diagnostisch onderzoek gedurende drie maanden;

- fase 2: presentatie van gebruikspatroon aan huisartsen:

- fase 3: opstelling van werkafspraak op basis van wetenschappelijke inzichten en eisen uit de praktijk vanuit gezamenlijk overleg tussen huisartsen, specialiten en deskundigen;

- Fase 4: presentatie werkafspraak in het informatiebulletin Diagnostisch Centrum met mogelijkheid tot comnentaar en kritiek;

- Ease 5: herhaling van driemaandse registratie, inventarisatie en analyse van alle aanvraagformulieren met als doel zo nodige bijstelling werkafspraak.

Eén van de activitejten van het E.D.C.M. was dus het "het gezamenlijk door hulsarts en specialist maken van werkafspraken voor diagnostisch onderzoek door de huisarts'. De behoefte aan evaluatie van deze vorm van samenwerking tussen huisarts en specialist was de aanlelding tot dit onderzoek. In de navolgende paragraaf zal dit nader uiteengezet worden. 


\subsection{AANLEIDING TOT HET ONDERZOEK}

De intensiteit van het gebruik van het Diagnostisch Centrum door de huisartsen toont een grote variatie. Naast huisartsen, die vrijwel geen onderzoek aanvragen, zijn er die meerdere aanvragen per dag verrichten. Het totaal aantal aanvragen voor alle huisartsen liet over de periode van het E.D.C.M. een geleidelijke toename zien van uiteindelijk 15 o (zie figuur 1.2.).

FIGUUR 1.2 .

Aantal onderzoeksaanvragen door huisartsen bij het Diagnostisch Centrum over de jaren 19791982 .

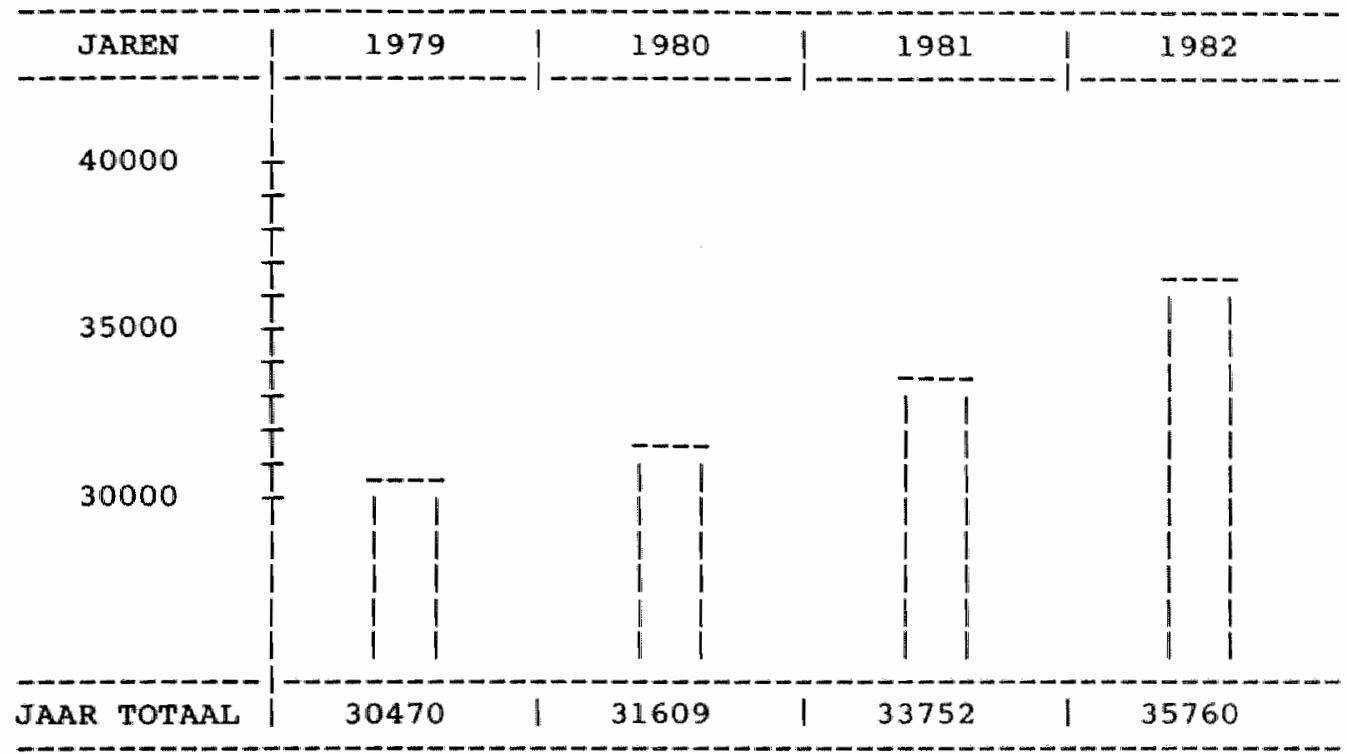

Nadere bestudering van bovenstaande in fase 5 genoemde registratie, inventarisatie en analyse voor alle acht de werkafspraken bracht naar voren, dat er ook met betrekking tot de toepassing van de werkafspraken grote verschillen bestaan tussen de huisartsen onderling. Een aantal huisartsen handelt slechts zelden in overeensteming met de werkafspraken. Daartegenover staan hulsartsen die vrijwel steeds overeenkomstig de werkafspraken onderzoek laten verrichten. Hier tussenin bevinden zich diverse varianten: 
huisartsen die de werkafspraken nu eens wel dan weer niet toepassen en ook in deze een niet altijd constant toepassingspatroon vertonen. Eveneens $z i j n$ er huisartsen, die de ene werkafspraak wel consequent toepassen, de andere darentegen niet.

De geconstateerde diversiteit in de toepassing van in gezamenlijk overleg tussen huisarts en specialist gemakte werkafspraken vormde de aanzet tot het onderhavige onderzoek. Stapsgewijs is deze arazet als volgt weer te geven:

- Diagnostisch Centra kunnen mogelijk ondersteuning bieden aan de huisartsgeneeskundige zorg.

- Twee experimenten met Diagnostische Centra zijn in gang gezet.

- Als een van de hoofddoelstellingen van het E.D.C.M. is gekozen voor "nagaan in hoeverre met een Diagnostisch Centrum een meer doeltreffend en doelmatig gebruik is te realiseren van de thans ter beschikking staande diagnostische faciliteiten".

- Als middel om dit te bewerkstelligen is voor werkafspraken betreffende diagnostische onderzoeken op het E.D.C.M. gekozen.

- De werkafspraken zijn geintroduceerd maar blijken in beperkte mate te worden toegepast.

- Ter verbetering van de toepassing van de werkafspraken is inzicht nodig in de factoren, welke het gebruik en de toepassing van werkafaspraken voor diagnostische onderzoeken beinvloeden. op basis van onderzoeksresultaten betreffende deze factoren kunnen strategleën worden ontwikkeld ter bevordering van deze toepassing, warmee een meer doeltreffend en doelmatig gebruik van diagnostiache facliteiten door de huisartsen bewerkstelligd kan worden. Een en ander ter ondersteuning van de huisartsgeneeskundige zorg.

In het navolgende hoofdstuk zullen de in deze aanzet aangegeven problemen worden uitgewerkt tot een onderzoeksvraagstelling. 


\section{VAN PROBLEEM TOT VRAAGSTELLING}

\subsection{PROBLEEM}

Om te komen tot een meer doeltreffend en doelmatig gebruik van de middels het E.D.C.M. ter beschikking staande diagnostische faciliteiten, is inzicht vereist in de factoren welke het gebruik daarvan beĩnvloeden.

\section{- doeltreffend gebruik van diagnostische voorzieningen}

Doeltreffend wil zeggen dat het specifieke doel, zoals dat met iedere diagnostische voorziening beoogd wordt, inderdaad wordt bereikt. Uitgebreide diagnostische faciliteiten zijn sinds kort binnen het bereik van de huisarts gekomen. Adequat gebruik en juiste interpretatie verruimen de diagnostische mogelijkheden voor de huisarts en zijn patient. Bij ondoeltreffend gebruik kan het tegenovergestelde het geval zijn. Enkele voorbeelden kunnen dit illustreren. Röntgen-onderzoek geeft bij de diagnostiek van het ulcus duodeni wel, darentegen bij een ulcus ventriculi diagnostiek geen voldoende uitsluitsel. Immers een ulcus duodeni is vrijwel altija goedaardig, een ulcus ventriculi daarentegen gaat vaker gepaard aan een maagcarcinoom.

In tegenstelling tot angina pectoris kunnen bepaalde hartritmeafwijkingen met behulp van E.C.G.-onderzoek met vrij grote zekerheid gediagnostiseerd worden. Tussen de angina pectoris aanvallen door zijn op het ECG meestal geen afwijkende bevindingen aanwezig. Geen ECG afwijking betekenent derhalve niet: geen angina pectoris.

Is een verhoogde bezinking in het algemeen vaak een aanwijzing voor een pathologisch proces, bij ouderen is dit daarentegen vaak een normale bevinding.

Het is ongetwijfeld zo, dat huisartsen in het algemeen in staat zijn de latste ontwikkelingen in diagnostiek adequaat in hun diagnostisch handelen te integreren. Daartegenover kan worden 
gesteld dat de diagnostische mogelijkheden zodanige ontwikkelingen te zien geven, dat extra informatie bij de hantering ervan wenselijk en zinvol is. Dit geldt niet alleen voor de technische ontwikkelingen van de diagnostische voorzieningen zelf, maa evenzeer voor de epidemiologische factoren, welke ten grondslag liggen an doeltreffend diagnostisch handelen van de huisarts. Als specifieke informatie in deze valt te noemen die betreffende de prevalentie warin sommige ziekten in bepaalde (sub)populaties voorkomen, de sensitiviteit en de specificiteit van diverse diagnostische testen afzonderlijk en van kleine of grotere testbatterijen gezamenlijk (Sturmans en Van Arkel, 1982). De klinisch epidemioloog houdt zich immers onder andere bezig met de betrouwbaarheid van diagnostische methoden en met het effect van diagnostische handelingen. Als voorbeeld: veel normaalwaarden stammen uit onderzoeken bij (poli)klinische patientenpopulaties. De prevalentie van bepalde ziekten is hier anders dan in de huisartspraktijkpopulatie. Daarenboven wordt meestal als normaalwaarde gehanteerd het gemiddelde + en - twee mal de standaarddeviatie. Bij hantering van dit criterium toont de Gauss curve dat bij ieder onderzoek reeds $5 \%$ van de onderzoeksbevindingen per definitie alls abnormal wordt geclassificeerd. Indien men meerdere bepalingen bij één patient laat verrichten, wordt zo op theoretische gronden de kans dat bij deze patient minstens één bepaling ten onrechte als afwijkend wordt geclassificeerd steeds groter. zo blijkt dit theoretisch getal bij 12 bepalingen (wordt in vele laboratoria als standara gezamenlijk bepald) reeds 17 to bedragen.

Op grond van de technische ontwikkelingen van de diagnostische voorzieningen, alsmede de epidemiologische kennis over diagnostische onderzoeken, lijkt het wenselijk om vanuit het oogpunt van doeltreffendheld werkafspraken voor diagnostische onderzoeken door de huisartsen in gezamenlijk overleg tussen huisarts, klinicus en epidemioloog op te stellen. 
- Doelmatig gebruik van diagnostische voorzieningen

Onder doelmatig gebruik wordt verstaan in overeenstemming met het doel warvoor iedere diagnostische voortiening beschikbar is. met andere woorden, voorkoming van oneigenlijk gebruik van de diagnostische voorzieningen.

Een aantal redenen voor het streven nar een meer doelmatig gebruik van diagnostische voorzieningen zijn:

* Grote interdokter variatie. Het quantitatieve gebruik van diagnostische faciliteiten door huisartsen vertoont reeds sinds jaren een grote interdokter-variatie (De Haan, 1974). Ook de gegevens van de diagnostische centra Oudenrijn en Maastricht bevestigen dit. Dit geldt voor alle diagnostische voorzieningen, zowel voor eenvoudig laboratorium-onderzoek als voor meer geavanceerde diagmostiek.

- Patientgebonden argumenten. Patienten worden vaak na eerst door de huisarts diagnostisch behandeld te zijn, voor verder onderzoek en therapie naar de specialist verwezen. Vanuit de patient bezien is het uitermate wenselijk, dat de diagnostische onderzoeken, welke door de huisarts werden verricht, doelmatig waren, zodat geen onnodige diagnostische onderzoeken verricht behoeven te worden.

- Financiele redenen. Sommige diagnostische voorzieningen zijn erg duur. Dit heeft zowel betrekking op laboratorium-onderzoek (RAST-test, HLA-27 bepaling, enz.) als op röntgen-onderzoek (IVP, colon inloop, enz.) en endoscopieën. De laatste jaren wordt het ziekenhuis en de specialist door de overheid geconfronteerd met budgettaire matregelen. De vraag is gerechtiga hoe lang diagnostische faciliteiten voor de huisarts ongebudgetteerd zullen blijven. Zeker nu meer geavanceerde en daardoor vaak duurdere diagnostische onderzoeken binnen de reikwijate van de huisarts komen, ligt het in de lijn der verwachtingen, dat in toenemende mate met kritische blik naar het diagnostisch 
handelen wan de huisarts gekeken zal gaan worden. Alleen een doelmatig gebruik van de diagnostische voorzieningen zal de kritiek, welke zich uitspreekt voor beperking van duurdere diagnostische faciliteiten voor de huisarts op grond van ondoelmatig gebruik ervan, kumnen weerleggen en de financiers motiveren deze faciliteiten aan de huisarts ter beschikking te blijven stellen. Door voorkoming van onnodige overlappingen worden diagnostische voorzieningen doelmatig gebruikt. Evenals de patient zijn de financiers van de gezondheidszorg uitermate gebaat bij een optimale afstemming op elkaar van het diagnostisch handelen van huisarts en specialist.

Zoals eerder aangegeven werd door het Diagnostisch Centrum Maastricht ervoor gekozen om onder andere met werkafspraken voor diagnostische onderzoekaanvragen een meer doeltreffend- en doelmatig gebruik ervan te bevorderen. In de navolgende paragraaf zal de informatie uit de literatur met betrekking tot het gebruik van diagnostische faciliteiten en de toepassing van werkafspraken daarbij worden weergegeven.

2.2. LITERATUURVERKENNING MET BETREKKING TOT HET GEBRUIK VAN DIAGNOSTISCHE FACILITEITEN EN DE TOEPASSING VAN WERKAFSPRAKEN VOOR DIAGNOSTISCHE ONDERZOEKEN DOOR (HUIS)ARTSEN.

Nederlandse onderzoeken, gericht op de toepassing van werkafspraken voor diagnostische onderzoeken door de huisarts, hebben wij niet gevonden. Wel zijn er literatuurgegevens handelend over het gebruik door huisartsen van diagnostische ziekenhuis-voorzieningen (visies/meningen).

In de Verenigde staten en Engeland zijn onderzoeken verricht naar factoren, welke het gebruik van diagnostische faciliteiten door (huis)artsen beinvloeden. Daarbij is van belang te vermelden dat de onderzoeken uit de Verenigde staten vaak niet alleen de huisarts regarderen, maar ook andere medische beroepsbeoefenaars, die evenals de huisarts, hun praktijk buiten het ziekenhuis uitoefenen, zoals algemeen internisten, kinderartsen e.d. 
Diagnostische faciliteiten voor de huisarts in het ziekenhuis kunnen de kwaliteit van de diagnostiek en de hulpverlening van de huisarts verbeteren. Eveneens kan van hieruit het samenspel tussen huisarts en specialist bevorderd worden (de Melker, 1980). Diagnostische mogelijkheden zijn in veel opzichten onmisbaar voor de huisarts en het belang ervan wordt - juist door de huisarts onderschat. In zijn eigen praktijk constateerde puylaert (1978) wel degelijk een daling van het aantal verwijzingen en ziekenhuisopnamen door het gebruik van diagnostische faciliteiten. Evenwel, verruiming van diagnostische faciliteiten voor huisartsen brengt niet zonder meer een verlaging van verwijscijfers met zich mee (Dopheide en van der zee, 1980). Een dergelijke substitutie van gezondheidszorgvoorzieningen kon evenmin worden bevestigd in de evaluatie van het experiment Diagnostisch Centrum Oudenrijn. Vanuit dit experiment wordt nader onderzoek, met als vraagstelling of door huisartsen meer gericht diagnostisch onderzoek aangevraagd kan worden door gebruik van een Diagnostisch Centrum, wenselijk geacht (Peters, 1982). Continuering van Diagnostische Centra wordt bepleit op grond van de constatering, dat in het ziekenhuis oudenrijn, in vergelijking met een referentiegroep van ziekenhuizen, in de sector van de nevenverrichtingen een duidelijke verschuiving is opgetreden van klinisch naar niet-klinisch handelen (Demmers e.a., 1984). Systematische registratie van het gebruik van diagnostische faciliteiten, initiatieven ter stimulering van overleg en het maken van werkafspraken vanuit Diagnostische centra wordt op basis van de evaluatiegegevens van het experiment Diagnostisch Centrum Maastricht eveneens. aanbevolen (Fop en Kerkhof, 1984).

De Melker en Van Soeren pleiten voor het hanteren van scherpe criteria ten aanzien van het gebruik van diagnostische faciliteiten door de huisarts (De Melker, 1980; Van Soeren, 1979). Alleen op deze wijze zouden de bezwaren, klevend aan het overhevelen van diagnostische procedures uit de specialistische geneeskunde naar huisartsen, kunnen worden ondervangen. De huisarts dient er zich bewust van te zijn, dat veel onderzoek uitsluitend dient om de 
elgen onzekerheld van de art: weg te nemen (Sisson, 1976). Dat het gebruik van röntgenologische onderzoekingen door de huisarts verantwoord is toont het onderzoek van Patterson (1974), gegeven diens conclusie dat de hulsarts tot redelijke indicatiestelling voor aanvaag daarvan in stalt is gebleken. Bij de door huisartsen aangevraagde röntgenologische onderzoekingen werd een groter aantal afwijkingen gevonden dan blj de door andere artsen aangevraagde onderzoekingen.

Ten aanzien van het gebruik van diagnostische faciliteiten door de huisarts zijn de volgende voor- en nadelen te noemen. Als voordelen: kwaliteitsverbetering van de zorgverlening door de huisarts, doordat de huisarts met meer zekerheid en meer verantwoord zijn eigen beleid kan bepalen en bovendien zonodig de patient gerlchter kan verwijzen. De belasting voor de patient kan dardoox duidelijk minder zijn. Als potentiele nadelen: ondeskundig en mogelijk overbodig gebruik met als gevolg onnodige belasting van patient en diagnost (de Melker, 1980).

Freeborn e.a. (1972) vermelden, dat artsen met een leidende rol in een groepspraktijk meer gebruik maken van diagnostische voorzieningen dan hun collega's. Artsen in een groepspraktijk maken bovendien als groep meer gebruik van diagnostische faciliteiten dan afzonderlijk werkende artsen. Artsen, die vanuit hun werksituaties dezelfde patienten behandelen, handelen bij de hulpverlening meer in overeenstemming met de normen van de beroepsgroep. dan hun collega's die afzonderlijk werken (sang-o Rhee, 1980). ook de opleiding, dat wil zeggen die aan een 'public school" of an een 'private school', blijkt van invloed: artsen opgeleid aan eer. 'private school' maken meer gebruik van de diagnostische voorzieningen (Eisenberg, 1981). Dit geldt eveneens voor artsen die opgeleid zijn in een academische setting, in tegenstelling tot hun 'perifeer' opgeleide collega"s (Pineault, 1977). Naast het instituut war men is opgeleid, wordt in de verenigde staten ook de regio war de opleiding heeft plaatsgevonden van invloed bevonden (Rose e.a., 1972). Artsen, werkend vanuit een meer wetenschappelijk georienteerde setting, blijken zich wat betreft 
hun aanvraagpatroon minder te laten beinvioeden door situaties van alagnostische onzekerheid. De in vergelijking met hen in "normale" hulpverleningssituaties lager scotende collega"s vragen in hulpverleningssituaties met diagnostische onzekerheid meer diagnostische onderzoeken aan.

Het antal jaren praktijkuitoefening beinvloedt eveneens het gebruik van diagnostische faciliteiten. Hoe hoger het a atal jaren praktijkervaring, des te lager het gebruik van diagnostische voorzieningen (Eisenberg, 1981).

Het zelf in de praktijk ter beschikking hebben van diagnostische faciliteiten levert en hoger gebrulk op, dan wanneer men zich hiervoor tot een instituut moet wenden (Chilas en Hunter, 1972). Een toename van de afstand tot de diagnostische voorziening vermindert het gebruik (Rose en Abel-Smith, 1972). Tenslotte spelen financiele overwegingen een rol, in geval aanvragen van diagnostische onderzoeken financieel worden gehororeerd (Schroeder en showstack, 1978).

Bij orientatie in de literatuur over de beinvioedingsmethoden voor het veranderen van het medisch handelen van artsen worden global drie beinvloedingsmethoden onderscheiden (Fowkes en Roberts 1984):

- hantering van richtijuen

- evaluatie van het practisch handelen

- feedback.

\section{a) gebruikmaking richtlijnen.}

Introductie van richtlijnen ten aanzien van het preoperatief laten maken van röntgenologische thorax-foto's door de vereniging voor radiologen in Engeland, leidde tot een duldelijke verlaging van het gebruik van deze diagnostische faciliteit door gpecialiaten (Fowkes en Roberts, 1984). Ook het gebruik van laboratoriumonderzoek en het voorschrijven van antibiotica bij de behandeling van patienten met pharyngitis, daalden door de introductie van richtlijnen in een eerstelijns gezondheidscentrum in de Verenigde 
Staten (Grimm e.a. "1975). Evenzeer nam het verrichten van overbodige onderzoeken bij patienten met acute medische problematiek af in een ziekenhuis in Engeland door het hanteren van werkafspraken (Young, 1980).

b) evaluatie practisch handelen.

Analyse van het handelen van de arts aan de hand van zijn verslaglegging, alsmede vergelijking van de handelswijze met richtlijnen leiden tot duidelijke verbetering in de behandeling van ziektebeelden als acute pneumenie, urineweg infecties, myocard infarct, gastroenteritis bij kinderen, maagbloedingen, acute blindedarm ontsteking en cholecystitus/cholelithiasis (Sanzaro e.a., 1978).

Eveneens werd verbetering geconstateerd in het gebruik van laboratoriumtesten door artsen in opleiding bij regelmatige beoordeling van de verslaglegging van de behandeling van patient door ervaren artsen (Martin e.a., 1980).

\section{c) feedback.}

Fowkes en Roberts (1984) vermelden, dat het geven van feedback aan (huis)artsen leidt tot wisselende resultaten in 'klinische gedragingen'. Zo vonden Brown en Uhl (1970) wel enige verbetering in voorachrijfgedrag en vermindering van chirurgische complicaties door het geven van feedback. Achong e.a. (1977) en Jones e.a. (1977) konden dit evenwel nauwelijks bevestigen bij hun studies nat het gebruik van antibiotica in de kliniek. Inhoudelijke informatieve feedback daarentegen gaf wel duidelijke verbetering te zien voor het gebruik van schildkliertesten (Rhyne e.a., 1979) en in de diagnostiek van buikpijn (Dombal e.a. 1974). Deze feedback diende wel gecontinueerd te worden om te voorkomen dat vroegere gedragingen weer werden gevolgd. Het alleen mar geven van informatie en het bijwonen van conferenties brachten nauwelijks enige verandering van het medisch handelen van specialisten teweeg (Wiliamson e.a., 1967 en Eisenberg e.a., 1977). Pogingen 
om het overmatig gebruik van laboratoriumonderzoek te verminderen met behulp van een nascholingsprogramma voor huisartsen ressorteerden weinig effect. Daarentegen gaf individuele feedback aan een groep internisten over de kosten van angevraagd onderzoek, (bij vergelijking van collega's onderling) zo'n 30 g verlaging te zien van het gebruik van deze diagnostische voorzieningen. Het meest uitgesproken was deze verlaging bij de zogenaande "duurste" artsen (Schroeder e.a., 1978).

Samenvattend zijn vanuit deze literatuuroriëntatie als mogelijke relevante factoren voor het gebruik van diagnostische faciliteiten door (huis)artsen naar voren te brengen:

- de positie van de arts in een groepspraktijk:

- het werken in een groepspraktijk;

- het werken met een gezamenlijk patientenbestand;

- het opleidingsinstituut;

- de aard van de specialisatie (academisch of 'perifeer');

- het werken vanuit een wetenschappelijke background:

- het aantal jaren praktijkuitoefening;

- het al dan niet beschikken over eigen diagnostische faciliteiten;

- de afstand van de praktijk tot de diagnostische voorziening;

- financiele overwegingen.

Ten aanzien van de kans van beinvloedingsmethoden voor het veranderen van het medisch handelen van (huis)artsen lijken methoden als hantering van richtijinen en evaluatie van het practisch handelen een groter effect te weeg te brengen dan nascholingsactiviteiten met feedback over de toepassing van werkafspraken.

In de navolgende paragraaf wordt de vraagsteliling van het onderhavige onderzoek nader uitgewerkt.

\subsection{VRAAGSTELLING}

Zoals vermeld (zie paragraaf 1.3. Aanleiding tot het onderzoek) werden bij de toepassing van de werkafspraken van het Diagnos- 
tisch Centrum grote verschilien vastgesteld tussen de huisartsen. Indien deze verschillen zouden blijven bestaan, zou het minder goed mogelijk zijn het effect van de hantering van werkafspraken te evalueren, ervan uitgaande, dat de toepasising van de werkafspraken meer doeltreffend en doelmatig gebruik van deze diagnostische voorzieningen betekent.

In de allereerste fase van het opzetten van dit onderzoek kwam dan ook de vraag naar voren of het niet mogelijk zou zijn door middel van bepaalde interventies de toepassing van de werkafspraken te bevorderen.

Als interventiemogelijkheid werd gedacht aan het geven van individuele feedback aan de hulsartsen over hun toepassing van de werkafspraken. Het onderzoek zou dan duidelijk maken in hoeverre de toepassing van de werkafspraken verandert door beinvloeding van de huisarts via individuele feedback ten aanzien van zijn toepassing van de werkafspraken.

Uit een dergelijk onderzoek zouden evenwel geen conclusies over de effecten van de gegeven feedback getrokken kunnen worden, omdat naast de individuele feedback andere factoren de toepassing van de werkafspraken door de huisartsen konden beinvloeden. Dit bezwar zou grotendeels te elimineren zijn door de huisartsen in te delen in twee groepen. Hierbij zou dan aan de ene groep wel en aan de andere groep geen individuele feedback gegeven worden. Deze opzet was echter minder wenselijk, ondat reeds door meerdere hujsartsen te kennen was gegeven individuele feedback op prijs te stellen. Individuele feedback aan slechts een deel van de huisartsen zou door een aantal hunner als benadeling ervaren kunnen worden. Daarenboven zou er door de "kleinschaligheid" van de regio (waarneemgroepen) mogelijk toch een te grote uitwisseling van informatie platsvinden tussen de huisartsen onderling, wardoor hun gedrag via deze "indirecte" feedback beInvloed zou kunnen worden.

Naast deze motieven was er een ander argument om het onderzoek allereerst te richten op de toepassing van de werkafspraken door huisartsen, zonder beinvloeding door welke interventie dan ook. 
Een onderzoek naar de toepassing van de werkafspraken zonder interventie te plegen zou informatie kunnen aandragen over soort en gewicht van factoren, die de toepassing van de werkafspraken beinvloeden in, hetzij belemmerend, hetzij bevorderend opzicht. Wordt de toepassing van de werkafspraak met name bepaald door de inhoud van de werkafspraken zelf, of zijn in deze vooral factoren, welke betrekking hebben op opvolggedrag in algemene zin, van belang? onder opvolggedrag hier te verstaan de mate warin gegeven voorschriften en adviezen worden opgevolgd. In hoeverre spelen factoren van de persoon van de huisarts een rol en in welke mate beinvloeden praktijkgebonden factoren het handelen van de huisarts ten aanzien van de toepassing van werkafspraken? Welke rol speelt in deze de appreciatie van het piagnostisch Centrum door de huisartsen? Kan de toepasbaarheid van de werkafspraken vergroot worden door verandering van de procedure van de totstandkoming van de werkafspraak of door andere introductie ervan? Welke vorm van evaluatie is het meest adequaat? Hoe waarderen de huisartsen feedback ten amzien van hun toepassing van de werkafspraken? Dienen de werkafspraken van tijd tot tijd bijgesteld te worden?

Op deze en vele andere vragen met betrekking tot de toepassing van de werkafspraken is in de literatuur nog geen antwoord te vinden. Desalniettemin wordt vanuit diverse invalshoeken de hantering van werkafspraken en protocollen in de geneeskunde bepleit (Van der Heijden, 1983). Met name röntgenfaciliteiten lijken daarvoor bij uitstek geschikt (Kasteleijn, 1983). Werkafspraken en protocollen zijn op vele terreinen van de geneeskunde toe te passen, zoals ten aanzien van het anamnestisch handelen, het diagnostisch handelen, het therapeutisch handelen, de begeleiding door de arts en combinaties hiervan. De werkafspraken, zoals geintroduceerd vanuit het Diagnostisch Centrum, betreffen het diagnostisch handelen van de huisarts. Vandaar dat van bovengenoemde gebileden het diagnostisch handelen van de huisarts, wat de toepassing van de werkafspraken betreft, als onderzoeksobject is gekozen. 
Het wijwel ontbreken van onderzoeksgegevens in de literatuur over de toepassing van welk soort werkafspraken dan ook, bevestigde de motivatie tot dit onderzoek. Als uiteindelijke vraagstelling woor het onderzoek werd gekozen:

\footnotetext{
'Welke factoren zijn van invloed op de toepassing door huisartsen van werkafspraken betreffende hun gebruik van diagnostische faciliteiten van een Diagnostisch Centrum?'
}

\section{Samenvatting:}

- Eer van de doelstelingen van het E.D.C.M. was een meer doeltreffend en doelmatig gebruik van de thans ter beschikking staande diagnostische faciliteiten te realiseren.

- Met werkafspraken voor diagnostisch onderzoek trachtte het E.D.C.M. dit doeltreffend en doelmatig gebruik te bevorderen.

- Registratie-gegevens van het diagnostisch centrum tonen, dat er grote verschilien bestaan tussen de huisartsen onderling met betrekking tot de toepassing van deze werkafspraken.

- Het vrijwel ontbreken van onderzoeksgegevens in de literatuur betreffende de toepassing van werkafspraken op dit gebied van het huisartsgeneeskundig handelen, motiveerde mede tot het doen van onderzoek naar de toepassing van werkafspraken door huisartsen. De vraagstelling van het onderzoek is: 'Welke factoren zijn van invloed op de toepassing door huisartsen van werkafspraken betreffende hun gebruik van diagnostische faciliteiten van een Diagnostisch Centrum?'.

In het navolgende hoofdstuk zal worden beschreven op welke wijze de vragsteling is geoperationaliseerd. 
3. INVENTARISERING VAN INFORMATIE MET BETREKKING TOT DE TOTSTANDKOMING VAN WERKAFSPRAKEN EN TEN AANZIEN VAN FACTOREN VAN INVLOED OP DE TOEPASSING VAN WERKAFSPRAKEN.

\subsection{DE TOTSTANDKOMING VAN WERKAESPRAKEN}

Het E.D.C.M. had gekozen voor het gebruik van werkafspraken ter bevordering van een meer doeltreffend en doelmatig gebruik van de diagnostische voorzieningen. Ten behoeve daarvan zijn de werkafspraken volgens een vaste pracedure opgesteld en gebruikt (zie paragraaf 3.1.1.). De door het E.D.C.M. gehanteerde procedure wordt vervolgens aan de hand van literatuurgegevens getoetst (zie paragraaf 3.1 .2$.$) .$

3.1.1. De totstandkoming van werkafspraken vanuit het Diagnostisch Centrum

Het Diagnostisch Centrum Maastricht heeft bij het opstellen van werkafspraken een gefaseerde werkwijze gevolgd. Een vijf-fasig model is gehanteerd:

Vanuit overleg tussen huisartsen en specialisten is allereerst het onderwerp gekozen, warvoor een werkafspraak opgesteld zou gaan worden. Vervolgens zijn de navolgende vijf fasen successievelijk doorlopen:

Eerste fase: gedurende een periode van drie maanden is de handelwijze van de huisartsen voor de onderzoeksaanvagen, warop de op te stellen werkafspraak betrekking dienden te gaan hebben, geregistreerd en geanalyseerd. Dit was mogelijk, doordat het Diagnostisch Centrum een aanvraagformulier hanteert, waarop de huisarts bij iedere onderzoeksaanvraag de nodige gegevens dient te noteren (zie bijlage I). Verwerking en analyse van deze gegevens door de projectgroep Evaluatie E.D.C.M. verschafte de mogelijkheid de handelwijze van de huisarten met betrekking tot het onderwerp van de op te stellen werkafspraak zichtbaar te maken. 
Tweede fage: De geanalyseerde handelwijze is via het Informatie bulletin van het Diagnostisch Centrum ter kennis gebracht van alle participerende huisartsen. Hierop aansluitend is een bijeenkomst georganiseerd (klinische agora) ter voorbereiding van de op te stellen werkafspraak. Op deze klinische agora zijn uitgenodigd: alle betrokken huisartsen, de betrokken specialisten en epidemiologen. zo zijn voor de werkafspraak voor schildklierfuncties de internist/endocrinoloog uitgenodigd en voor de werkafsprak röntgenonderzoek lumbosacrale wervelkolom de chirurg/orthopaed, de neuroloog en de rheumatoloog. Bovendien zijn de specialisten uitgenodigd die als diagnost bij de uitvoering van de betreffende aanvragen voor diagnostische onderzoeken betrokken zijn, bijvoorbeeld voor de werkafspraak schildklierfunctie de klinisch-chemicus en voor de werkafspraak röntgenonderzoek lumbosacrale wervelkolom de radio-diagnost. In een consensus-bijeenkomst is de geanalyseerde handelwijze besproken en is de gewenste handelwijze naar voren gebracht, daarbij aansluitend op de mogelijkheden in de praktijk. Relevante gegevens uit de literatuur zijn hierbij als extra informatie aangereikt. Van belang zijnde epidemiologische standpunten zijn bovendien naar voren gebracht.

Derde fase: Door het Diagnostisch Centrum is in aansluiting aan deze consensus-bijeenkomst een concept van de werkafspraak opgesteld. Vervolgens is dit ter kennis gebracht van de huisartsen en de betrokken specialisten ter commentaar en kritiek. Zonodig werd naar aanleiding hiervan een nieuwe bijeenkomst georganiseerd.

Vierde fase: Na verwerking van de kritiek en het commentaar is de "definitieve' werkafspraak geformuleerd en aan de huisartsen aangeboden ter schriftelijke accoordverklaring.

vijfde fase: Na verloop van tijd zijn, zonder aankondiging vooraf, de op de werkafspraak betrekking hebbende aanvraagformulieren gedurende drie maanden opnieuw geregistreerd, geanalyseerd, beschreven en teruggekoppeld naar huisartsen en specialisten. 
In bovenstaande procedure zijn met name de volgende zaken van belang. Het is noodzakelijk gebleken, dat de huisartsen van meet af an intensief bij de opstelling van de werkafspraken betrokken worden. Hiermee dient mede an de eigen verantwoordelijkheid van de huisartsen met betrekking tot de toepassing van de werkafspraken gestalte gegeven te worden. Dit geldt zowel voor de keuze van het onderwerp, waarvoor een werkafspraak opgesteld zal gaan worden, als voor de inhoud van de werkafspraak. Bij het vaststellen van de gewenste handelwijze en bij de evaluatie daarvan zulien huisartsgeneeskundige argumenten een cruciale rol dienen te spelen bij de beoordeling van de zinvolheid en de wenselijkheid van het medisch handelen van de huisartsen. Het is van belang dat specialistische deskundigheid, epidemiologische gegevens en richtlijnen uit de literatuur daarin een complementaire rol vervullen.

Ter illustratie de samenvatting het verslag van de bespreking, zoals die heeft platsgevonden op de klinische agora over de opstelling van de werkafspraak van E.C.G.-aanvragen (Informatiebulletin Diagnostisch Centrum 1981).

\section{BESPREKING:}

" Wat eigenlijk opvalt bij deze evaluatie is het verschil tussen het scala van diagnosen warbij de huisartsen een ECG aanvragen enerzijas en het door cardiologen aangegeven indicatiegebied.

De oorzaak hiervan moet liggen:

- In een niet altijd volledige kennis van zaken bij de huisarts ten aanzien van datgene wat een ECG in rust in fysiologische en patho-fysiologische $z$ in a an informatie te bieden heeft.

- Daarop aansluitend: bij welke werkhypothesen in diagnostische zin steun is te verwachten van een ECG in rust, en bij welke niet.

ofwel, geredeneerd vanuit de positie van de huisarts in zijn dagelijks functioneren: "deze patient heeft (misschien) een hartziekte of een ziekte warbij het hart (mogelijk) ook te lijden heeft. Heb ik nast mijn anamnese en onderzoek nog andere diagnostische hulpmiddelen nodig bij het komen tot een werkhypothese of brengt me dat alleen maar op zijpaden of op een dwaalspoor?"

Bijvoorbeeld: De anamnese van een plotseling ontstane of plotseling verergerende A.P. kan zo typisch zijn, dat het laten maken van een ECG door de huisarts via 
het Diagnostisch Centrum op zijn zachtst uitgedrukt. tijaverilies betekent.

OE: "Deze man mankeert niets, maar hij is bang dat hij wat aan zijn hart heeft; ik zal ter geruststelling een ECG laten maken.

Als je ex op grond van anamnese en onderzoek bij deze patient zeker van bent dat er cardial niets aan de hand is, kan een ECG in je beleid passen: wanneer het ECG niet alleen de patient, mar ook jezelf gerust moet stellen, begeef je je op glad ijs.

Samenvattend: De diagnostische waarde van het ECG in rust ligt. in het vastleggen van:

- ritme- en geleidingsstoornissen van het hart

- hypertrofie van boezems en kamers

- beschadiging van kamerspierweefsel.

Een ECG in rust is onbetrouwbaar voor de diagnostiek van coronair lijden bij:

- het ontbreken van blijvende hartspierbeschadigingen

- ECG-registratie buiten een angineuze aanval.

In de definitieve werkafspraak resulteerde deze bespreking onder andere in de navolgende zinvolle indicaties voor ECGaanvragen:

* Bij pijn op de borst: Alleen documentatie van bestamae nartspierbeschadiging; ST-T afwijkingen tijdens pijnaanval.

* Ter geruststelling van de patient, als hulpmiddel achter de hand, alleen als de huisarts ervan overtuigd is, dat de klachten van de patient niet berusten op een hartaandoening.

3.1.2. De totstandkoming van werkafspraken in de literatuur.

De in de vorige paragrafe beschreven, door het E.D.C.M. ontworpen, procedure voor de totstandkoming van werkafspraken is door ons aan de hand van literatuurgegevens getoetst.

Het wordt van primair belang geacht, dat het idee om met werkafspraken te gaan werken geintroduceerd wordt vanuit een erkend en gerespecteerd instituut (American College of Physicians, 1978). Evenzeer is het wenselijk dat de toe te passen richtlijnen door de werkers in de praktijk relevant worden bevonden. Wat dit betreft blijken er opmerkelijke overeenkomsten tussen huisartaen en specialisten te bestaan (wagner e.a., 1976).

Uit onderzoeken (Fowkes en Roberts, 1984; Nelson, 1976) resulteren globale aanwijzingen over de stappen die genomen dienen te 
worden bij het opstellen van werkafspraken. Daarbij worden drie fasen onderscheiden:

Eerste fase: Waarneming en zo mogelijk registratie van het feitelijk handelen van de arts.

De wijzen waarop de gegevens verzameld kumnen worden, verschillen. Zo wordt bijvoorbeeld enerzijds melding gemakt van het verstrekken van mondelinge ad hoc informatie door de participanten over hun eigen handelen in de consensus-bijeenkomst en anderzijds van geavanceerde verslaglegging met behulp van een computer in de huisartsenpraktijk (Barnett e.a., 1978).

Tweede fase: Vergelijking van het feitelijk handelen met de gewenste handelswijze.

Bij het vaststellen van de te volgen nieuwe werkwijzen dienen aspecten als doeltreffendheid, veiligheid, haalbaarheid, kosten en mogelijk andere factoren te worden betrokken. Op grond hiervan kan aangegeven worden welke veranderingen in het feitelijke gedrag wenselijk zijn. Opnieuw dient dan deze gewenste handelswijze op de zojuist genoemde factoren bezien te worden. Indien de afspraken geaccordeerd worden, kan overgegaan worden tot de derde fase.

Derde fase: Introductie van werkafspraken in het dagelijks handelen van de arts.

De genoemde drie fasen dienen als een circulair proces gezien te worden (zie figuur 3.1.). Het is van groot belang na te gaan of de genoemde veranderingen ook inderdaad worden gerealiseerd. zo niet, dan is het van belang te evalueren waarom dit proces niet heeft plaats gevonden (Nelson, 1976). 


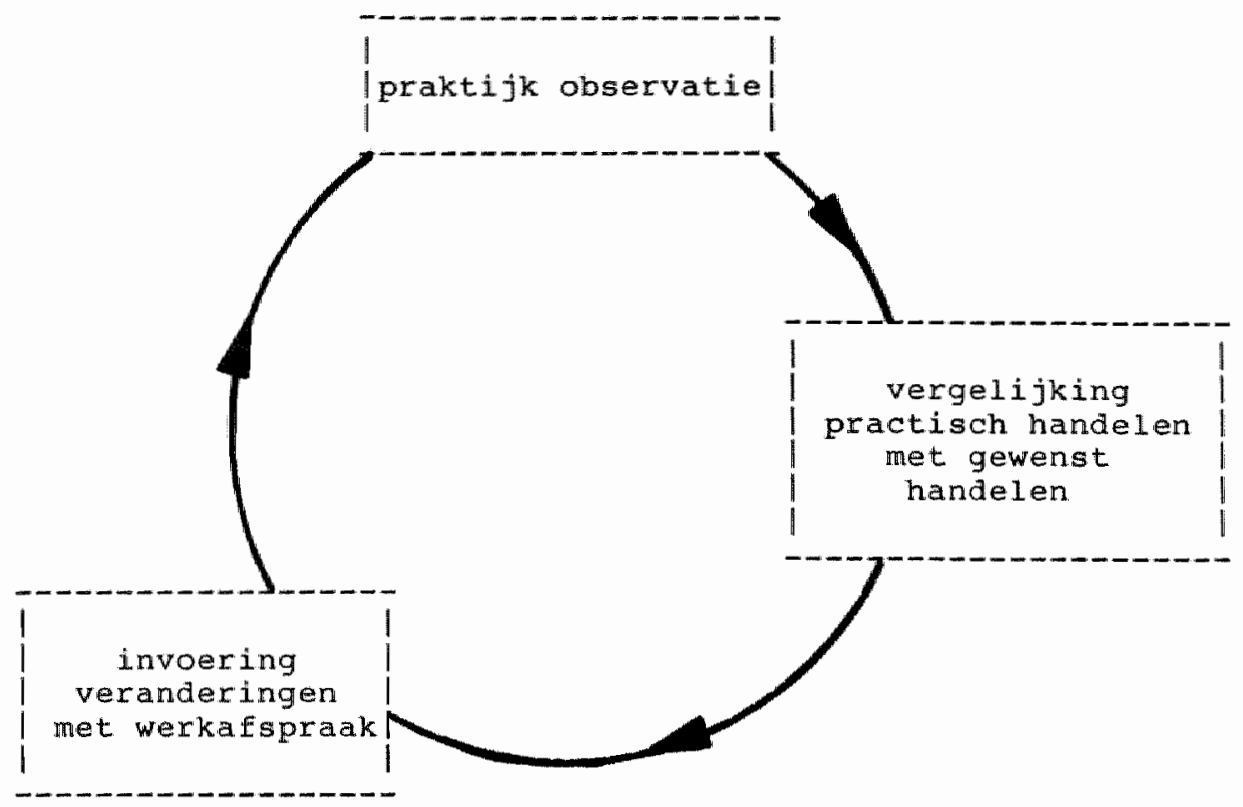

Afgezien van bovengenoemde in de literatuur vermelde aanbevelingen blijven vele vragen met betrekking tot het gebruik van werkafspraken voor diagnostische onderzoeken onbeantwoord. Het betreffen met name vragen aangaande de in de tweede fase angegeven vergelijking van het feitelijk handelen van de huisartsen met de gewenste handelwijze, zoals:

a. Welke werkafspraken maken de meeste kans op toepassing?

b. Hoe moet de werkafspraak feitelijk in de praktijk opgesteld worden?

a. Hoe te handelen indien voldoende richtlijnen voor werkafspraken ontbreken?

ad a. Welke werkafspraken maken de meeste kans op toepassing?

Voorop dient gesteld te worden dat het te verkiezen is de elsen niet te hoog te stellen. Als voorbeeld: idealiter zouden urine- 
weginfecties bij vrouwen door de huisarts behandeld dienen te worden op geleide van urinekweek en antiblogram. In de praktijk zou dit evenwel betekenen, dat er hierdoor een aantal dagen gewacht dient te worden. Dit is voor patient en huisarts in het merendeel der gevallen onaanvaardbaar. Mogelijk is dit de verklaring voor het feit dat Brook en Apple (1973) constateren dat 'academische' protocollen voor patienten met urineweginfecties. hypertensie en ulcus pepticum slechts in een laag percentage worden nagekomen.

Sanzaro (1974) beklemtoont, dat een werkafspraak beter kan worden opgesteld met het oog op wat maximaal haalbaar is, dan met het oog op wat idealiter wenselijk is. Men zou kunnen uitgaan van de door veel artsen toegepaste handelwijze. Deze aanpak geeft inderdaad reeds aanleiding tot duidelijke veranderingen in het handelen van de arts (Mintz e.a., 1976). Andere onderzoekers (Fernow, e.a., 1978) brengen evenwel naar voren dat deze aanpak remmend kan werken. Een aantal artsen zal altijd wel redenen kunnen aangeven, waarom bij hun patient juist van de "gemiddelde handelwijze" afgeweken dient te worden.

Moet bovendien ook het nut dat de patient heeft van het medisch handelen niet van doorslaggevende betekenis zijn bij de bepaling van de gewenste handelswijze?

Evenzozeer is het van belang te bezien welke normen en waarden bij het hulpverleningsgedrag van huisartsen door de beroepsgroep zelf van belang worden geacht. Jacobs e.a. (1983) onderscheiden in deze drie normen:

- een huisarts dient zoveel mogelijk te voorkomen, dat hij een relevante lichamelijke aandoening over het hoofd ziet:

- een huisarts dient zoveel mogelijk te voorkomen, dat de patient onnodige lichamelijke, intrapsychische, relationele of sociale schade wordt toegebracht:

- een huisarts dient zoveel mogelijk te voorkomen, dat hij psycho-sociale factoren die relevant zijn voor de hulpverlening over het hoofd ziet. 
ad b. Hoe moet de werkafspraak feltelijk in de praktijk opgebouwd worden?

Welke richtiljnen dienen te worden aangehouden bij de op- en vatstelling van werkafgpraken? wie dient naast de huisarts bij de samenstelling van de werkafspraak betrokken te worden?

Welke bronnen zijn geschikt on als richtsnoer te dienen bij het vaststellen van de gewenste handelwijze van de huisarts? Gegevens van klinische trials zijn feitelijk minder geschikt hiervoor, omdat er hierbij steeds wordt uitgegaan van een geselecteerde patientenpopulatie. Gerandomiseerd onderzoek in de huisartsenpraktijk ontbreekt vaak. Hieraan bestaat een toenemende behoefte blj de verdere ontwikkeling van de huisartsgeneeskunde. Duidelijke richtijinen voor het diagnostisch handelen van de huisarts ontbreken voor het merendeel der aiagnostjsche onderzoeken. In de effectiviteit met betrekking tot de toepasing van een diagnostische werkafspraak zijn vier dimensies te onderscheiden (Roberts, 1983): Diagnostische effectiviteit, management effectiviteit, effectiviteit ten aanzien van het eindresultaat voor de individuele patient en populatie effectiviteit.

Beoordeling van het diagnostisch handelen op deze dimensies lijkt aangewezen. Idealiter zou wóór het maken van diagnostische werkafspraken daartoe informatie verzameld dienen te worden over:

- prevalentie van bepaalde ziekten in bepalde (sub)populaties;

- de sensitiviteit en de specificiteit van diverse testen afzonderlijk:

- de sensitiviteit en de specificiteit van kleinere of grotere testbatterijen gezamenlijk (Sturmans en van Arkel, 1982).

ook andere argumenten zullen bij het opstellen van werkafspraken voor de huisarts gewogen dienen te worden.

In de gezondheidszorg is de drempel tot de eerste lijn laag. Vele lichamelijke verschijnselen, inclusief die welke voortvloeien uit gevoelens van onbehagen, onvrede of overbelasting, worden aan het loket van de huisarts gepresenteerd. Verdient ook hier een diag nostische handelwijze van uitsluitingsdiagnostiek met sensitieve 
methoden, die betrouwbaar negatieve resultaten naar voren brengen, de voorkeur (Dunning, 1984)? Leidt dit niet tot een defensieve geneeskunde, warvan het de vraag is of de patient bij de huisarts hier het meest mee gebaat is? Immers veel en onnodig onderzoek zal hiervan het gevolg kunnen zijn.

ad c. Hoe te handelen indien voldoende richtlijnen voor werkafspraken ontbreken?

In geval van gebrek aan richtijinen worden consensusbijeenkomsten als een mogelijkheid genoend (Caspari, 1983). Het belangrijkste verschil met aangereikte richtijnen vanuit de literatuur en/of standaardwerken en/of officiele rapporten is, dat bij de consensus bijeenkomst alle aanwezigen hun bijarage kunnen leveren bij het opstellen van de werkafspraken en dat de conclusies door al de betrokkenen worden onderschreven.

3.2. FACTOREN VAN INVLOED OP DE TOEPASSING VAN WERKAFSPRAKEN DOOR HUISARTSEN TEN AANZIEN VAN HET GEBRUIK VAN DIAGNOSTISCHE EACILITEITEN VAN EEN DIAGNOSTISCH CENTRUM

\section{2 .1 . Inleiding}

In de literatulurverkenning met betrekking tot het gebruik van diagnostische faciliteiten en de toepassing van werkafrpraken voor diagnostische onderzoeken in paragraaf 2.2 . in reeds een aantal factoren naar voren gebracht.

Aangezien uit deze literatuurverkenning weinig informatie over toepassingspatronen van werkafspraken, het medisch handelen van huisartsen betreffende, naar voren kwam, was verdere oriëntatie over andere toepassingspatronen, het medisch handelen van huisartsen betreffend en factoren, welke hierop van invloed zijn, wenselijk. 
Vanuit een drietal invalshoeken zijn factoren geinventariseerd:

- Het verwijzen van de huisarts naar de specialist (zie paragraaf $3.2 \cdot 2 \cdot)$.

- Het voorschrijfgedrag van (huis)artsen (zie paragraaf 3.2.3.).

- Factoren specifiek voor de toepassing van werkafspraken vanuit een Diagnostisch Centrum, voor een deel aansluitend op gegevens uit de compliance literatuur en en theoretisch model uit de beleidsleer (zie paragraaf 3.2 .4$.$) .$

In paragraaf 3.2 .5 . zijn de als relevant beoordeelde factoren samengevat en in een negental categorieün gegroepeerd.

\subsubsection{Het verwijzen door huisartsen.}

Het is te verwachten, dat er tussen de factoren welke het verwijzen van de huisartsen beInvloeden en de factoren welke van invloed zijn op de toepassing van werkafspraken door huisartsen ten aanzien van het gebruik van diagnostische voorzieningen, grote overeenkomsten bestaan.

Bij de factoren van invloed op het verwijzen door de huisartsen wordt onderscheid gemaakt in structurele factoren en factoren betreffende de persoon van de huisarts en zijn relatie met de mpecialist (Dopheide, 1982).

Als structurele factoren te noemen:

- praktijkaruk (aantal patientencontacten per uur);

- praktijkgrootte;

- leeftijdsverdeling praktijk;

- urbanisatiegraad praktijk;

- regio waar praktijk gevestigd is;

- afstand praktijk tot dichtstbijzijnde ziekenhuis;

- artal ziekenhuisbedden per 1000 inwoners.

Naar de varlabelen betreffende de persoon van de huisarts en zijn relatie met de specialist is nauwelijks systematisch onderzoek verricht. Wel zijn in de loop der jaren door diverse onderzoekers 
incidenteel factoren naar voren gebracht. 'onzekerheidstolerantie' wordt door de Melker (1979) als een kenmerk gezien, dat de verwijzingen mede bepalt. Zowel Dopheide en Van der tee (1980) als Jacobs e.a. (1983) vinden a anwijzingen voor samenhangen tussen de taakopvatting van de huisartsen en zijn mate van verwijzen. Ook Van Zutfen (1984) vermeldt, dat het door hem aangetoonde verband tussen taakopvatting en gespreksvoering een aanwijzing inhoudt, dat de attitude een var de drijvende krachten is voor het gedrag van de huisarts. In een later onderzoek bevestigt Dopheide (1982) de vermoede samenhang tussen verwijscijfer en taakopvatting. Hij stelt de vraag in hoeverre nader onderzoek naar de rol aie de patient zelf speelt in de patientenstroom tussen eerste- en tweede lijn wenselijk is. Dit zou betekenen, dat er naast de structurele variabelen en de variabelen betreffende de persoon van de huisarts en diens relatie met de specialist ook nog een categorie patientgebonden variabelen dient te worden opgenomen. Rop e.a. (1979) verklaren de grote individuele verschillen tussen een achttal huisartsen, werkend vanuit eenzelfde praktijksituatie, voor een deel vanuit de praktijk- en privésituatie van de huisartsen, zoals groei of juist afname van zijn praktijkgrootte, stresssituaties in praktijk of in gezin. Huygen en de Melker (1973) geven als verklaring voor het door hen, in hun eigen duo-praktijk, destijds gevonden lage verwijscijfer en hoog gebruik van diagnostische faciliteiten hun grote aandacht voor psycho-sociale problematiek, waardoor zijeen indicatie voor een verwijzing naar een specialist zeer kritisch bezien. ook Raupp (1971) vond reeds een negatieve samenhang van het verwijspercentage met het gebruik van laboratorium, therapeutische instrumenten en controle methoden. Ruhe (1967) constateerde destijas een samenhang tussen het hoge verwijscijfer en het niet hanteren van een kaartsysteem.

Samenvattend worden als relevante factoren betreffende het verwijzen door huisartsen onderscheiden:

- praktijkaruk (aantal patientencontacten per uur);

- praktijkgrootte; 
- Leeftijasverdeling praktijk:

- urbanisatiegraad praktijk;

- regio war praktijk gevestigd is;

- afstand praktijk tot dichtsbijzijnde ziekenhuis;

- aantal ziekenhuisbedden per 1000 inwoners;

- de houding van de huisarts ten aanzien van te nemen risico;

- de taakopvatting van de huisarts;

- de praktijk- en privé ormstandigheden van huisarts ;

- de aandacht voor psycho-sociale problematiek:

- het gebruik van laboratorium, therapeutische instrumenten en controlemethoden:

- het gebruik van een kaartsysteem.

\subsubsection{Het voorschrijfgedrag van (huis)artsen}

Bij de toepasing Van werkafspraken door hulsartsen spelen gedragsmatige factoren vermoedelijk ook een grote rol. Bij de oriëntatie over andere toepassingspatronen, het medisch handelen van huisartsen betreffende en gedragsmatige factoren, welke hierop van invloed zijn, is een literatuurstudie gedaan over het voorschrijfgedrag van (huis)artsen.

Onder voorschrijfgedrag verstaan we de mate, warin de (huis)arts medicamenten voorschrijft en de keuze van de medicamenten die hij voorschrijet.

De factoren, welke van invloed zijn op het voorschrijfgedrag van (huis)artsen, zijn in drie soorten te onderscheiden (Meyboom et a1. , 1984):

- externe factoren:

- patient gebonden factoren:

- (huis) arts gebonden factoren.

Samenvattend worden in de literatuur de navolgende factoren (voor het merendeel incidenteel) naar voren gebracht:

- ad externe factoren:

- voorlichting en informatie (Benzodiazepines, 1973); 
- maatschappijstructuur (Marinker, 1973);

- naam en faam van de farmaceutische industrie (Becker et al." 1972):

- farmaceutische reclame (Böttiger, 1973 en Lamberts, 1975).

- ad patient gebonden factoren (Mulier, 1972):

- opleidingsniveau;

- inkomensniveau:

- ziektekosten verzekeringsvorm patient;

- geslacht van de patient;

- leeftijd van de patient (Goedhard, 1980);

- verwachtingspatronen van de patient (Van der Hart, 1978).

- ad huisarts gebonden factoren:

- de mate waarin hulpverlening vanuit integrale benadering patient (Joyce, 1970):

- angang met de patient (Joyce, 1970);

- attitude aspecten ten opzichte van de matschappij als geheel en de professie in het bijzonder (Muller et a1.., 1971);

- beroepssatisfactie (Melville, 1980);

- opleidingsinstituut (Joyce, 1970);

- houding arts tegenover nascholing (Wolff, 1974);

- intercollegiale toetsing (wolff, 1974);

- wijze van samenwerken en al dan niet geisoleerd werken (Miller, 1973):

- jaren praktijk ervaring (Wolff, 1974);

- tijdsaruk van consult (Muller, 1972 en Bremer, 1983);

- praktijk grootte (Dunnel en Cartwright, 1972);

- plats van vestiging (Wolff, 1974):

- apotheekhoudend of niet (Muller, 1972).

In schema 3.1. zijn alle factoren, zoals zij vanuit de literatuurstudie naar voren komen, bij de toepassing van diagnostische faciliteiten (2.2.), bij het verwijzen door hulsartsen (3.2.2.) en bij het voorschrijfgedrag van (huis)artsen (3.2.3.), schematisch gegroepeerd. 


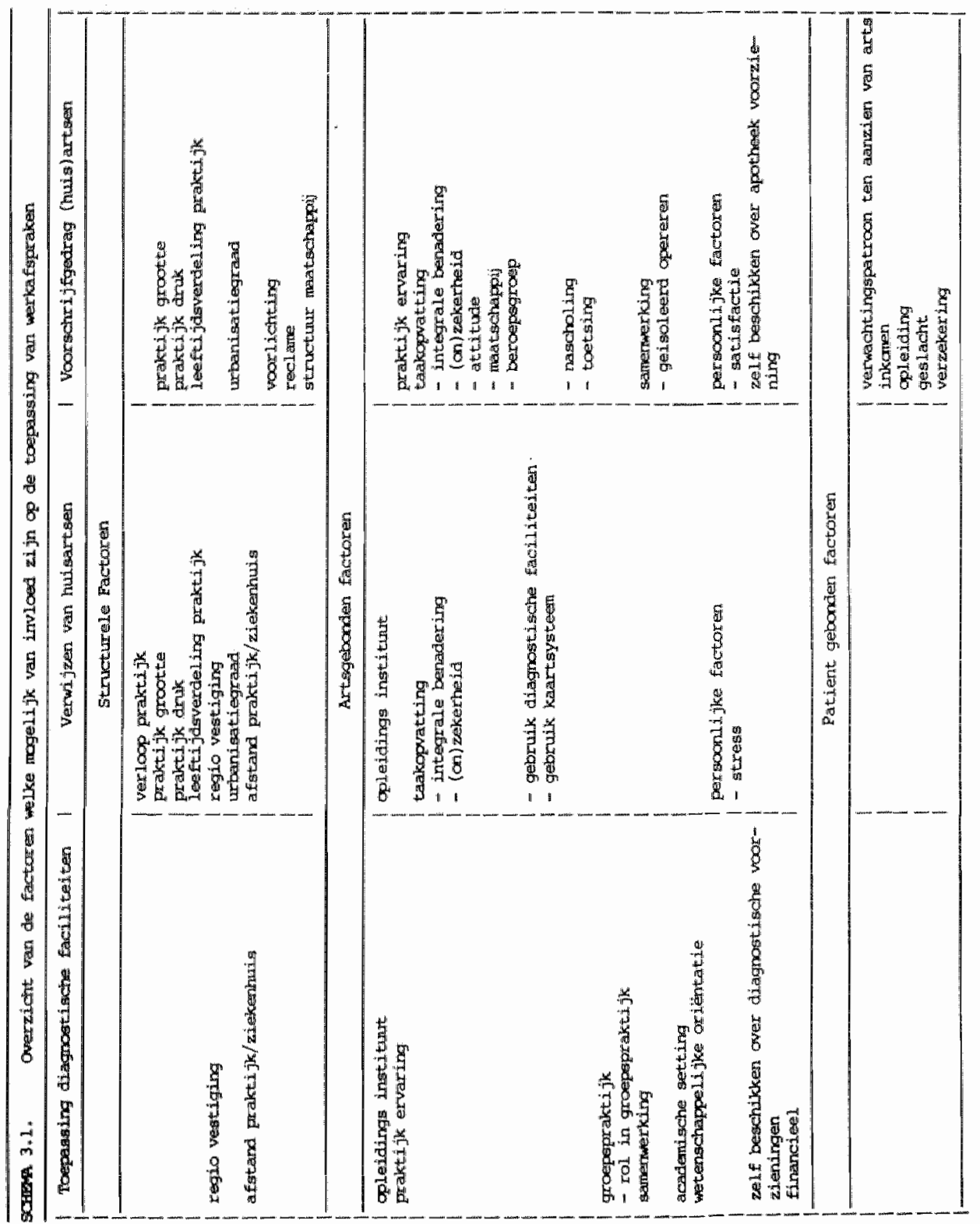


3.2.4. Factoren specifiek woor de toepassing van werkafspraken varuit een Diagnostisch Centrum

Door het ontbreken van een specifiek theoretisch model bij de inventarisatie van de factoren van invloed op de toepassing van werkafspraken is ten aanzien van de toepassing van werkafspraken door huisartsen vanuit een Diagnostisch Centrum een analogie getrokken met de compliance van de patient. Onder die compliance worat verstaan de mate warin door de patient de door de arts gegeven voorschriften en adviezen worden opgevolgd. In analogie daamee kan het opvolggedrag van huisartsen ten anzien van werkafspraken worden omschreven als de mate watin door de huisartsen de door het Diagnostisch Centrum gegeven voorschriften en afspraken worden opgevolgd. De werkafspraken kunnen gezien worden als een beleidsplan om tot oplossing van het gestelde probleem te komen: een meer doeltreffend en doelmatig gebruik van diagnostische voorzieningen te realiseren.

De in de beleidsleer onderscheiden elementen van beleidsvoering zijn mogelijk te vertalen naar de beleidsvoering ten aanzien van de toepassing van de werkafspraken. De elementen van de beleidsvoering kunnen ideaal-typisch in fasen als volgt omschreven worden:

- beleidsoverdracht

- beleidformulering

* beleidfeducatie

- beleidfacceptatie

- beleidfoepassing

- beleidsinterpretatie

- beleidscontrole.

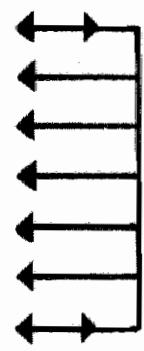

De beleidsoverdracht heeft betrekking op het voorstel van het Diagnostisch Centrum een meer doeltreffend en doelmatig gebruik van diagnostische voorzieningen te realiseren door werkafspraken te hanteren (appreciatie doelstellingen Diagnostisch Centrum). De overdracht kan pas echt begrijpelijk zijn, wanneer deze onderbouwd wordt met de overweglingen, die hieraan ten grondslag $\mathbf{l i g}-$ gen. Deze overwegingen dienen voort te vloeien uit de evaluatie, 
warmee de huisartsen zich geidentificeerd hebben (appreciatie coördinatie en evaluatie door het Diagnostisch Centrum). De beleidsformulering is een noodzakelijke communicatievoorwarde on tot effectieve overdracht te komen. Eerst nadat expliciet is nagegaan of de overdracht en de formulering duidelijk zijn en de partijen zich ermee kunnen verenigen, volgen de beleidseducatie (apprecilatie protocollen en werkafspraken algemeen) en de beleidsacceptatie (accordatie werkafspraken inhoudelijk). In deze fase dienen met name normatieve componenten meer gewicht te krijgen dan de cognitieve.

Pas als het beleid geheel geaccepteerd is, kan men werkelijk toekomen aan de toepassing ervan in de praktijk (signalering bevorderende of belemmerende factoren). Hiermee kan de eigen verantwoordelijkheid van de huisartsen extra gewicht krijgen omdat zij desgewenst ideeën kunnen aandragen, om te komen tot een aangepaste beleidsinterpretatie an de gestelde doelen te bereiken. Tenslotte resteert de beleidscontrole op de juistheid van het gekozen beleid en op de wijze warop het beleid wordt uitgevoerd. Vanit deze laatste fase kan teruggekoppeld worden naar elk van de voorgaande Easen.

Voor de duidelijkheid is het zinvol nogmaals te beklemtonen dat de huisartsen primair verantwoordelijk zijn voor de toepassing van de werkafspraken. Het Diagnostisch Centrum is primair verantwoordelijk voor het scheppen van voldoende voorwaarden om tot een adequate communicatie te komen.

Vanuit intensief gevoerd overleg, mede gebaseerd op bovenstaande gegevens, met leden van het uitvoerend team van het Diagnostisch Centrum, alsmede met een aantal huisartsen, die van het Diagnostisch centrum gebruik maken, kwamen de navolgende factoren, mogelijk specifiek voor de toepassing van werkafspraken vanuit een Diagnostisch Centrum, naar voren:

- De wardering van het Diagnostisch Centrum door de huisartsen als een erkend en gerespecteerd instituut; geapprecieerd zowel in doelstellingen als in organisatorische opzet en uitvoering. een en ander blijkens wardering voor de centraal coördinerende rol van het Diagnostisch Centrum voor alle diagnostische aan- 
vragen en voor de zinvolheid van gegevensvermelding op het aanvraagformulier.

- De behoefte van de huisartsen om vanuit hun taakopvatting te werken met protocollen en werkafspraken. Welke redenen liggen an het al dan niet gewenst vinden van de hantering van de werkafspraken ten grondslag: taakafbakening huisartsgeneeskunde? Steun in samenwerking? Basis voor overleg met en consultatie van de specialist? Afsteming hulpverlening specialist en huisarts? structurering, toetsing eigen handelen en nascholing? Juridische zekerstelling?

- De erkenning door de huisartsen van de centrale functie van het Diagnostisch Centrum bij de hantering van de werkafspraken. vinden de huisartsen de wijze warop vanuit het Diagnostisch Centrum de werkafspraken werden opgesteld het meest geschikt? onderschrijving behoefte aan concrete werkafspraken? Appreciatie van de opstellingsprocedure van de werkafspraken? Accordatie van de werkafspraken inhoudelijk huisartsgeneeskundig?

- De beinvloeding van de toepassing van de werkafspraken in het dagelijks handelen door factoren als de uitgebreidheid van de werkafspraak en het rendement van de werkafspraak.

Samenvattend worden de navolgende factoren als mogelijk specifiek voor de toepassing van werkafspraken vanuit een Diagnostisch Centrum naar voren gebracht:

- De appreciatie van de doelstellingen van net Diagnostisch Centrum.

- De appreciatie van de organisatorische opzet en uitwoering van het Diagnostisch Centrum.

- De behoefte van de huisartsen aan protocollen en werkafspraken in het algemeen.

- De appreciatie van de opstellingsprocedure van de werkafspraken.

- De behoefte aan concrete werkafspraken.

- De accordatie van de werkafspraken inhoudelijk.

- De uitgebreidheid van de werkafspraken.

- Het rendement van de werkafspraken voor het practisch handelen. 


\subsubsection{Samenvatting en groepering van de factoren}

De wele in de voorgande paragrafen lparagraaf $2.2 ., 3.2 .2 .$, 3.2.3. en 3.2.4.) genoemde factoren zijn, voor een deel aansluitend op bovenstaand theoretisch model uit de beleidsleer te ordenen in negen categorieën:

- Eactoren betrekking hebbend op de appreciatie van de doelstellingen van het Diagnostisch Centrum (categorie I).

- appreciatie van de doelstellingen zelf.

- appreciatie van de wijze warop de realisatie van de doelstellingen wordt nagestreefd.

- mate warin door de huisartsen werd geloofd in de realisatie van de uiteindelijk nagestreefde effecten: meer doeltreffend en doelmatig gebruik van de ter beschikking staande diagnostische faciliteiten *

- Factoren betrekking hebbend op de appreciatie van de organisatorische opzet van het Diagnostisch Centrum (categorie II).

- wardering voor de centrale coördinerende rol van het Diagnostisch Centrum voor alle diagnostische aanvragen.

- erkenning van de zin van de gegevensverzameling.

- acceptatie van de wijze warop de gegevens werden verzameld.

- Factoren met betrekking tot de taakopvatting van de huisartsen over het gebruik van protocollen en werkafspraken in het algemeen in de huisartsgeneeskunde (categorie III).

- erkenning van de zin van het werken met protocollen en werkafspraken in de hulsartsgeneeskunde

- onderschrijving van een aantal redenen welke ten grondslag zouden kunnen liggen aan het al dan niet gewenst vinden van de hantering van protocollen en werkafspraken, onderscheiden in: 
* taakafbakening huisartsgeneeskunde;

* steun in samenwerking;

* basis voor overleg en consultatie specialist;

* afsteming hulpverlening specialist en huisarts:

* structurering nascholing;

* toetsing eigen handelen;

* zekerheid ten opzichte van patient;

* plaatsbepaling huisartsgeneeskunde tegenover overheid en financiers.

- Factoren betreffende de algemene opstellingsprocedure van de werkafspraken (categorie IV).

- wardering van de eigen betrokkkenheid bij de vaststelling van het gebied waarover de werkafspraken gaan.

- wardering voor de inspraak in de opstelling van de werkafspraken.

- Factoren, betrekking hebbend op de hantering van de werkafspraken vanuit en door het Diagnostisch Centrum (categorie V).

- wardering van de introductie van werkafspraken vanuit het Diagmostisch Centrum.

- waardering van de wijze waarop informatie over het gebruik van de werkafspraken wordt verstrekt.

- Factoren betrekking hebbend op de samenstelling van concrete werkafspraken (categorie VI).

- behoefte aan concrete werkafspraak.

- inhoudelijke huisartsgeneeskundige accordatie van de werkafspraak.

- Factoren betrekking hebbend op de uiteindelijke toepassing van de werkafspraken in de dagelijkse praktijk (categorle VII).

- bevorderende of belemmerende factoren bij de uiteindelijke toepassing van de werkafspraken: 
* uitgebreidheid werkafspraak:

* praktijkdruk;

* verwachtingspatroon van de patient;

* rendement van de werkafspraak;

* gebrek aan feedback;

* haalbaarheid van de voorgestelde werkwijzen.

- ervaren dat de werkafspraak een doeltreffender en doelmatiger gebruik van diagnostische faciliteiten ten gevolge heeft.

- al dan niet zelf beschikken over de diagnostische voorziening.

- Factoren betreffende persoonsgebonden kenmerken van de huisarts (categorie VIII).

- aantal jaren praktijkervaring.

- al dan niet samenwerken met andere huisartsen.

- betrokkenheld bij wetenschappelijk onderwijs en/of onderzoek.

- verwijspercentages in het algemeen.

- verwijspercentage naar de specifieke specialismen, waarop de werkafspraken betrekking hebben.

- de quantitatieve gebruikmaking van de diagnostische voorzieningen.

- Factoren betrekking hebbend op structurele kenmerken van de huleartspraktijk (categorie IX).

- praktijkgrootte.

- werken met afspraakspreekuur.

- gebruikmaking van een kaartsysteem.

- afstand van praktijk tot ziekenhuis.

- urbanisatiegraad.

In figuur 3.2. zijn bovenstaande negen categorieën schematisch gerangachikt weergegeven.

Op de wijze warop de factoren zijn gemeten wordt in de volgende paragrafen nader ingegaan. 
FIGUUR 3.2.

Schematisch overzicht van negen categorieên van factoren in relatie tot opzet Diagnostisch Centrum en de hantering van werkafspraken.

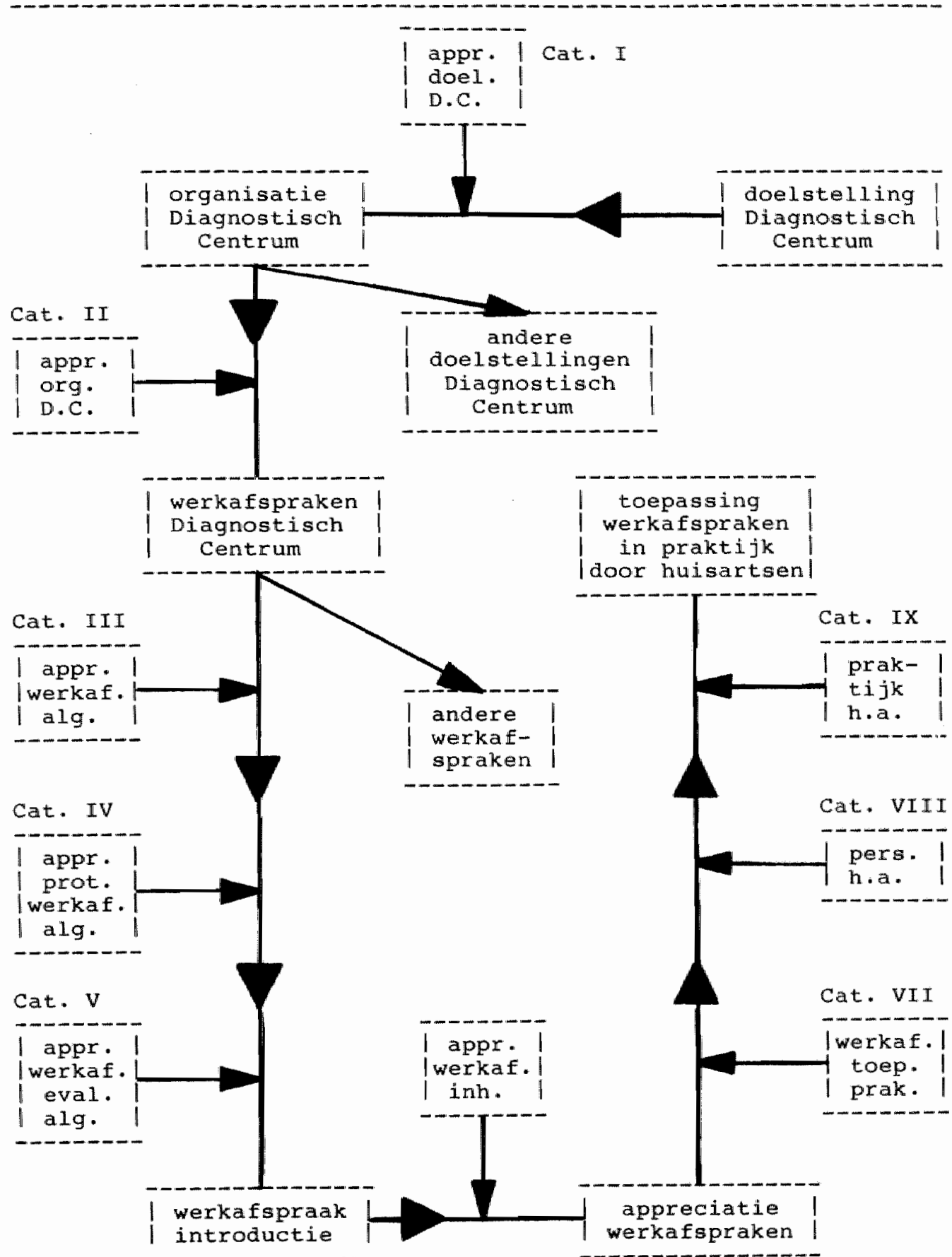




\section{ONDERZOEKSOPZET}

\subsection{TYPE ONDERZOEK}

Zoals vermeld bracht orientatie in de literatuur naar voren, dat er over de toepassing door huisartsen van werkafspraken voor diagnostische onderzoeken noch empirische noch theoretische modellen bestaan. Op grond hiervan dient het onderzoek dan ook een explorerend en beschrijvend karakter te dragen, zowel ten aanzien van het gebruik en de toepassing van werkafspraken als met betrekking tot de factoren, welke hier mogelijk op van invloed zouden kunnen zijn. Tengevolge hiervan is het onderzoek breed opgezet en zijn veel factoren in de exploratie betrokken. De vraagstelling is feitelijk: "Welk wan de ingeschatte factoren en variabelen $z i j n$ van invloed op de toepassing door huisartsen van werkafspraken betreffende het gebruik van diagnostische faciliteiten?"'

Bij de verdere bewerking is nagegaan of er factoren gegroepeerd kunnen worden. Vervolgens is geanalyseerd welke factoren de huisartsen onderscheiden wat betreft de toepassing van de werkafspraken, een en ander met het oog op mogelijkheden ter hypothese vorming voor nader toetsend onderzoek.

De onderzoeksopzet wordt schematisch weergegeven in figuur 4.1 . 
gebruik van

diagnostische

faciliteiten

door huisarts

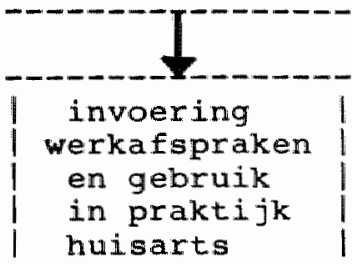

1

$\mid$ toepas - |

I sing

|werkaf-

spraak |

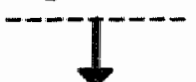

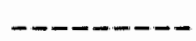

| enquêtel | refer. I

h.a. I
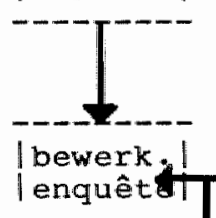
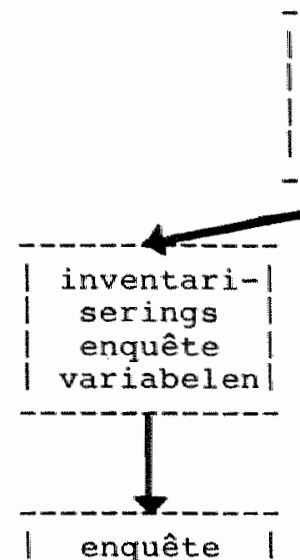

huisartsen

D.C.
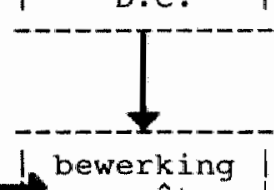

toepas-

sing

werkaf-|

spraak

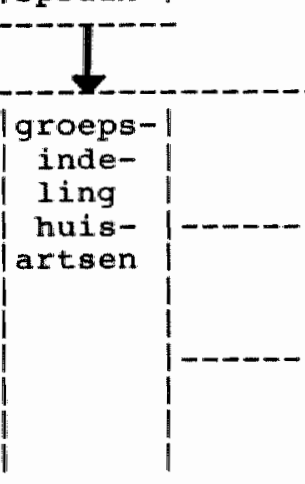

factoren van invloed

op toep. huisartsen

werkafspraken voor

diagnostisch onderzoek I

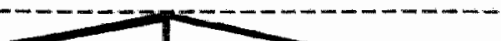

$\left|\begin{array}{c}\text { structu- } \\ \text { rering } \\ \text { interview }\end{array}\right|$

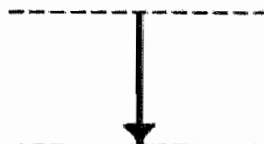

interview

huisartser D. C.

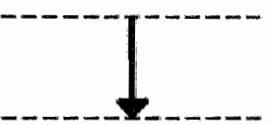

bewerking interview

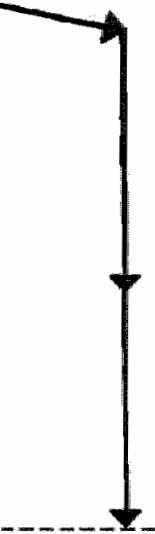

algemene gegevens D.C. 


\subsection{WIJZE VAN GEGEVENSVEZAMELING}

- De toepassing van de werkafspraken.

Door het Diagnostisch Centrum is een aanvragformulier ontworpen voor alle aanvragen voor diagnostische onderzoeken. Het aanvraagformulier bevat een speciale ruimte voor het verstrekken van gegevens door huisartsen (zie bijlage I).

De huisartsen wordt gevraagd hierop te vermelden, welke de belangrijkste problemen of klachten van de patient zijn, welke onderzoeksbevindingen zij vaststellen, welke diagnosen zij (indien magelijk) stelien, of er andere actuele diagnosen zijn, welke medicatie de patient gebruikt, welke indruk zij hebben van de ernst van het probleem, hoe vak de patient voor deze klacht hen raadpleegde en tenslotte welke de reden is voor de aanvraag van het diagnostisch onderzoek.

Voor elke diagnostische onderoeksaanvraag wordt een aanvraagformulier ingevuld. Analyse van deze aanvraagformulieren stelde ons in staat na te gaan of de huisartsen de werkafspraak al dan niet toepasten. Van toepassing van een werkafspraak is sprake wanneer de huisarts handelt in overeenstemming met de in de werkafspraak gegeven richtlijnen. op de wijze warop de aanvraagformulieren zijn beoordeeld en het toepassingspercentage van de huisartsen is bepaald, wordt in paragraaf 4.3 .1 .2 . nader ingegaan.

- Factoren welke de toepassing van de werkafspraken beinvloeden.

De factoren welke mogelijk van invloed zijn op de toepassing van de werkafspraken zijn allereerst geinventariseerd (paragraaf 3.2.). De gegevensverzameling betreffende deze factoren is op drie wijzen geschied, namelijk door midiel van:

- een schriftelijke enquête (paragraaf 4.3.2.1.);

- een daaropvolgend interview (paragraaf 4.3.2.2.);

- inventarisatie van gegevens over de huisartsen en over de praktijk van de huisartsen (paragraaf 4.3.2.3.). 
Daarnaast is een deel van de enquête, die werd voorgelegd aan de huisartsen die samenwerken met het Diagnostisch Centrum, eveneens ter referentie ter invulling aangeboden an een referentiegroep van Nederlandse huisartsen (paragraaf 4.3.2.1.).

Los van de onderzoeksopzet is gedurende het tijdsbestek van het onderzoek aan de huisartsen, die gebruik maken van het Diagnostisch centrum, feed back verstrekt met betrekking tot hun individuele toepassing van de werkafspraken. De gegevens hieromtrent worden in hoofdstuk 7 naar voren gebracht.

\subsection{METHODEN VAN ONDERZOEK.}

\subsubsection{Het meten van de toepassing van de werkafspraken.}

4.3.1.1. De keuze van de te meten werkfspraken.

In de eerste fase van het onderzoek was het plan van elke werkafspraakcategorie één werkafspraak nader te onderzoeken:

- één radiodiagnostisch onderzoek;

- één onderzoek ten aanzien van klinisch-chemische diagnostiek;

- ECG-aanvragen;

- één endoscopisch onderzoek van het maag-darmkanaal.

Het onderzoek beoogt na te gaan welke factoren van invloed zijn op de toepassing van de werkafspraken. Bij nadere uitwerking van het onderzoek bleek het wenselijk eveneens te bestuderen of ex in de werkafspraken zelf mogeljk factoren gelegen zijn, die mede bepalend zijn voor de mate warin de huisartsen de werkafspraak toepassen.

Staan de huisartsen echt achter de in de werkafspraak overeengekomen onderzoeksindicaties of $z i j n ~ z i j$ in de praktijk van het dagelijks handelen toch een andere mening toegedaan? Dit betekende, dat ex meer in de "diepte' naar iedere werkafspraak gekeken diende te worden. 
Had de huibarto behoefte aan een werkafspraak op dit gebied? zou de hulsarts op grond van zij̉n praktische ervaring één of meerdere van de zinvol geachte onderzoeksindicaties willen schrappen of veranderen? Leidt in de ogen van de huisarts het gebruik van de werkafspraak tot een meer doeltreffend en doelmatig gebruik van deze diagnostische voorzieningen? Draagt het hanteren van de werkafspraak ertoe bij, dat minder patienten met problematiek op het gebled van de werkafspraak naar de specialist worden verwezen? Indien de patient alsnog wordt verwezen, wordt de patient dan varuit een meer gerichte vraagstelling naar de specialist verwezen?

Vragen dienaangaande moesten in de enquête verwerkt worden. Het was onmogelijk dit voor vier werkafspraken in één enquete te realiseren zonder het risico te lopen, dat hierdoor de invulling van de enquête door de uitgebreidheid in ernstige mate geschaad zou worden.

Op grond van deze argumenten werd gekozen voor bestudering van twee werkafspraken. Om alsnog binnen de vier werkafsprakcategorieën enigszins te variëren werd gekozen voor één werkafspraak voor onderzoek ten aanzien van klinisch-chemische diagnostiek, te weten leverfunctietests en voor de werkafspraak voor EcG-aanvragen.

- De werkafspraak voor ECG-aanvragen is gekozen omdat hierin zeer systematisch melding wordt gemakt van een zevental indicaties, waarbij een ECG-onderzoek zinvol wordt bevonden (schema 4.1.). Door de systematische opzet van de werkafspraak is het goed mogelijk deze inhoudelijk te evalueren. 
SCHEMA 4.1 .

Werkafspraak ECG-aanvragen .

Zinvolle indicaties voor dit onderzoek:

Bevindingen:

a. bij hartkloppingen, hartbonzen, e.d.:

b. bij ritmestoornissen:

c. bij wegrakingen, duizeligaanvalien of fracturen bij oudere patienten:

a. bij geruis aan het hart (ook bij het kind):

e. bij hypertensie:

f. bij pijn op de borst:

\section{Vragen:}

ritme- of geleidingsstoornis? préexcitatie?

contrôle effect therapie ritme- of geleidingsstoornis?

boezem en/of kamerhypertrofie geleidingsstoornis?

effect op het hart? contrôle effect therapie

alleen documentatie van bestaande hartspierbeschadiging: ST-T-afwijkingen tijdens pijnaanval?

g. Als hulpmiddel, ter geruststelling van de patient, alleen als huisarts ervan overtuigd is, dat de klachten van de patient niet berusten op een hartaandoening.

- Van de werkafspraken voor klinisch-chemische onderzoeken is uiteindelijk aan de werkafspraak voor aanvragen van leverfunctietests de voorkeur gegeven boven de werkafspraak voor schildklierfunctietests on de navolgende redenen. Op de eerste plats worden veel meer leverfunctietests aangevraagd dan schilaklierfunctietests. Daarenboven is de werkafspraak voor schildklierfunctietestaanvragen eenvoudig. De werkafspraak voor het aanvragen van schildklierfunctietests bevat namelijk als hoofdadvies zowel bij verdenking op hypothyreoidie als op hyperthyreoidie te beginnen met een T4-bepaling. Waarschijniljk mede hierdoor is de spreiding in de mate van toepassing onder de huisartsen niet zo groot.

De werkafspraak voor het aanvragen van leverfunctietests is daarentegen complexer en bevat een groot aantal richtijinen: richtlijnen inzake de meest in aanmerking komende combinaties van tests bij icterische patienten, niet-icterigche patienten met een vergrote lever, patienten met vage klachten, met verdenking van alcoholmisbruik, met voor hepatitis suspecte ver- 
schijnselen: verder richtlijnen inzake de meest in aamerking komende combinatie van tests ter controle van een mild verlopende hepatitis en richtlijnen bij verdenking, respectievelijk controle van mononucleosis infectiosa.

De afsraken over onderzoeksaanvragen zijn gekoppeld aan het klinische beeld (zie schema 4.2.).

ook bij deze werkafspraak is het door de systematische opbouw goed mogelijk de toepassing van de werkafspraak te evalueren. Dit gaf in de keuze de doorslag.

SCHEMA 4.2 . Werkafspraak aanvragen leverfunctietests.

Indicaties voor onderzoeksaanvragen.

Klinisch beeld:

a. de patient met een icterus e.c.i.:

b. niet icterische patienten met een vergrate lever:

c. patienten met vage en algemene klachten:

d. verdenking op alcoholabusus:

e. hepatitisbeeld:

f. contrôle mila verlopende hepatitis

9. mononucleosis infectiosa:

\section{Test:}

bilirubine (totaal - direct) alkalische fosfatase (alk. fos.), $\gamma-$ GTP, SGOT, SGPX

alk. fos., $\gamma$-GTP, SGOT, SGPT

alk. fos., $\gamma$-GTP, SGPT

alk. Fos., $y$-GTP, SGOT, SGPT

bilirubine (totaal - direct)

alk. fos. "Y-GTP" SGOT,

SGPT, HBs-antigeen

- bij volwassenen

- bij kinderen indien verdacht voor hepatitis

Iedere 14 dagen: SGOT, SGPT, $\gamma$-GTP (indien aanvankelijk verhoogd), HBs-antigeen (indien aanvankelijk verhoogd)

aantal leucocyten en differentiatie paul/Bunnell (bij) negatieve uitkomst en duidelijke verdenking te herhalen na 1 , eventuee 1 weken) oriënterend leveronderzoek: $r$-GTP. Eventueel te herhalen na 2 à 3 weken SGPT en 2 a 3 maanden. 
De overige werkafspraken zijn niet betrokken in de ondergoeksultwerking om de navolgende redenen:

- Bij de beoordeling van de toepassing van de werkafspraak voor röntgenonderzoek van de lumbosacralewervelkolom was er een te groot verschil tussen de twee beoordelaars, die aan de hand van de aanvraagformulieren het al dan niet toepassen van de werkafspraak door de huisartsen bepaliden. In slechts 22 van 32 beoordeelde aanvraagformulieren was er overeenstenming tussen beide beoordelaars.

- De beoordeling van de toepassing van de werkafspraak voor aanvragen voor röntgenonderzoek van de thorax werd in sterke mate beinvloed door het veelvuldig gebruik van de aanvraagind catie 'uitsluiting maligniteit' .

- Hetzelfde gold ten opzichte van de beoordeling van de toepassing van de werkafspraak voor marmografisch röntgenonderzoek.

- De werkafspraak voor röntgenonderzoek van maag-duodenum viel af, omdat daaromtrent een anoer onderzoek in gang was gezet.

- De werkafspraak voor endoscopisch onderzoek van het maag-darmkanaal was ten tijde van de start van dit onderzoek nog niet geintroduceerd.

De invoering van de werkafspraak voor ECG-aanvragen gebeurde in het december 1981 nummer van het Informatiebulietin van het Diagnostisch Centrum. Voor aanvragen van leverfunctietests geschiedae dit op gelijke wijze in april 1982. Beide werkafspraken kwamen tot stand volgens de eerder aangegeven samengtellingsprocedure (zie pag. $37 \mathrm{e.v.}$ ).

4.3.1.2. Beoordeling van de toepassing van de werkafspraken.

Zoals vermeld, wordt door de huisartsen voor leder dilanostisch onderzoek een aanvraagformulier ingevuld. 
Aan de hand van de invuling van bepaalde onderdelen van het aanvraagformuliex (zie schema 4.3.) kon worden nagegaan of de huisartsen de werkafspraken al dan niet toepasten. Indien aanvraagformulieren niet of inadequaat waren ingevuld, was de beoordeling van de toepassing van de werkafspraken niet magelijk.

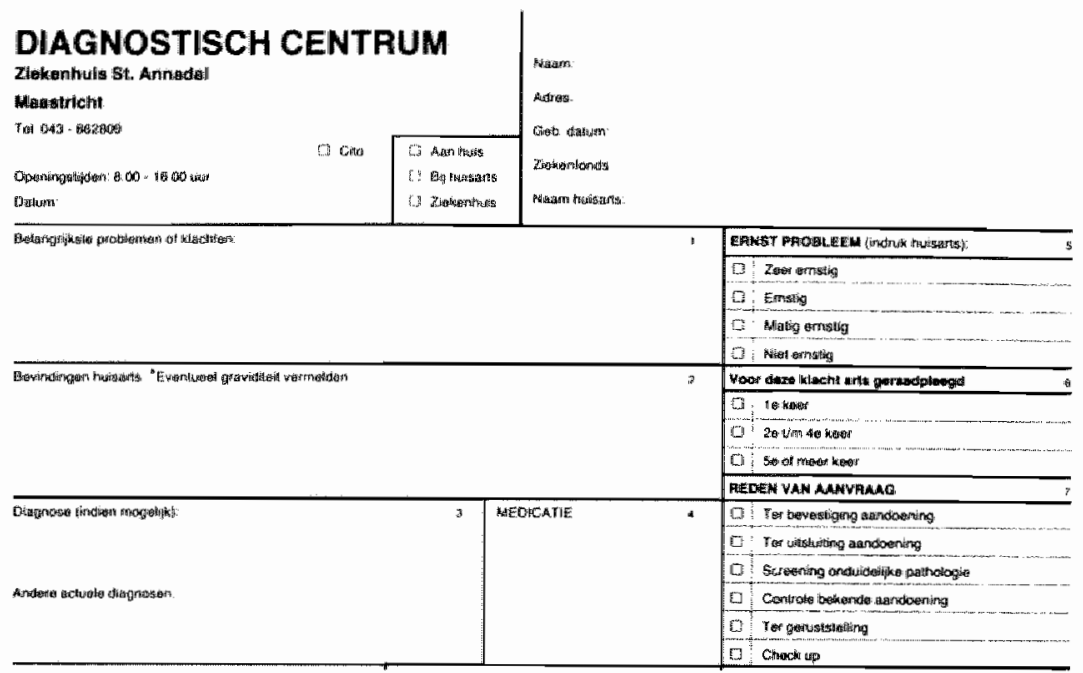

To dienden bij de aanvragen voor ECG-onderzoek ofwel de aangegeven problemen en klachten van de patient (zinvolle indicaties voor dit onderzoek $a, c$ en $f$, zie schema 4.1.), ofwel de weergegeven bevindingen van de huisarts (zinvolle indicaties voor dit onderzoek $b$ en $d, 4.1$.$) , ofwel de geconstateerde diagnose (zin-$ volle indicaties voor dit onderzoek b en c, 4.1.), ofwel de reden van aanvraag 'ter geruststelling' (zinvolle indicaties voor dit onderzoek $\mathrm{g}, 4.1$.$) op het aanvraagformulier overeen te stemmen$ met de indicaties in de werkafspraak.

Bij de aanvragen voor leverfunctietests diende dit op gelijke 
wijze te geschieden voor de aangegeven problemen of klachten van de patient (afspraken voor onderzoeksamnragen $c$ en $d$, zie schema 4.2.), voor de weergegeven bevindingen van de huisarts (afspraken voor onderzoeksaanvragen $a$ en $b, 4.2$.$) en voor de geconstateerde$ diagnose (afspraken voor onderzoeksaanvragen e, en g, 4.2.). Aldus was het mogelijk iedere diagnostische onderzoeksaanvraag van de huisartsen op de toepassing van de werkafspraken te beoordelen. Bij de beoordeling van de toepassing van de werkafspraken voor ECG-aanvragen was het antwoord steeds: of in overeensteming of in strijd met de werkafspraak.

Bij de beoordeling van de toepassing van de werkafspraak voor aanvragen van leverfunctietests kwam het echter voor, dat er minder laboratoriumtests werden aangevraagd dan in de werkafspraak aangegeven. Indien deze aanvragen overigens wel in overeensteming met de werkafspraak waren, werden zij als in overeensteming met de werkafspraak beoordeeld. Aanvragen met te veel aangevraagde laboratoriumtests zijn steeds als in strijd met de werkafspraak beschouwd.

Van deze beoordeling is verder nog nagegaan of er sprake was van beoordelingsvariatie tussen verschillende beoordelaars. Daartoe zijn de beoordelingen van twee beoordelaars met elkaar vergeleken. Voor de twee, voor dit onderzoek gekozen werkafspraken, bleek er sprake te zijn van een vrijwel identiek beoordelingspatroon (zie tabel 4.1.). Als beoordelaars functioneerden twee afgestudeerde basisartsen.

TABEL 4.1 .

Inter - beoordelaars betrouwbaarheidsanalyse met betrekking tot beoordeling diagnostische aanvragen op toepassing van de werkafspraken.

\begin{tabular}{|c|c|c|}
\hline $\mathrm{ECG}$ & $\begin{array}{l}\text { beoordelaars } \\
\text { aantal beoordeelde huisartsen } \\
\text { totaal aantal aanvragen } \\
\text { overeensteming tussen beoordelaars }\end{array}$ & $\begin{array}{r}2 \\
3 \\
13 \\
12\end{array}$ \\
\hline Leverfunctietesten & $\begin{array}{l}\text { beoordelaars } \\
\text { aantal beoordeelde huisartsen } \\
\text { totaal aantal aanvragen } \\
\text { overeensteming tussen beoordelaars }\end{array}$ & $\begin{array}{r}2 \\
33 \\
33 \\
32\end{array}$ \\
\hline
\end{tabular}


De beoordeling heeft plaatsgevonden voor elke huisarts afzonderlijk, zowel voor de ECG- als voor de leverfunctietestsaanvagen. Voor iedere mand is het percentage toepassing in overeensteming met de werkafspraken bepaald voor de ECG- en voor de leverfunctietests-adnvragen afzonderlijk, alsmede voor de aanvragen van ECG-onderzoek en leverfunctietests gezamenlijk (zie tabel 4.2.).

TABEL 4 . 2 .

Huisarts ............... Maand ........

ECG-aanvragen

Aanvragen lever-

functietests

Totaal aanvragen
A

B

C $x: 8$

$Y$ 웅

$\mathrm{Z} 8$

4.3.1.3. De perioden warover de toepassing van de werkafspraken is gerneten en de toepassingsscore is bepaald.

- Periode warover de toepassing van de werkafspraken is gemeten.

De onderzoeksaanvragen van de huisartsen zijn door het Diagnostisch Centrum maandelijks van elke huisarts afzonderlijk verzameld. Hierdoor was het mogelijk de aanvragen van de huisartsen maandelijks te beoordelen.

In totaal zijn negen maanden, verspreid over vier periaden gemeten:

- eerste periode: augustus 1981;

- tweede periode: mart, april en mei 1983;

- derde periode: september, oktober, november 1982;

- vierde periode: december 1982, januari 1983. 
De keuze van de bovengenoemde perioden was geen toevallige, maar is tot stand gekomen op grond van de navolgende factoren en argumenten. De schijnbare chronologische tegenstrijaigheid tussen de tweede en de derde en vierde periode zal eveneens daardoor verklaard worden.

* ad eerste periode: augustus 1981 .

Het was zinvol een meting te verrichten vóbafgaand aan het invoeren van de werkafspraken. Op die wijze leek het mogelijk vast te stellen in welke mate er verschillen zouden zijn in de toepassing van de werkafspraken vóór en ná het invoeren daarvan. Zoals vermeld is de werkafspraak voor ECG-aanvragen in december 1981 ingevoerd.

De werkafspraak voor aanvragen leverfunctietests is in april 1982 ingevoerd. Van de periode hieraan vóórafgaand waren alleen de onderzoeksanvragen van de maand augustus 1981 bij het Diagnostisch Centrum voor nadere beoordeling beschikbaar.

* ad tweede periode: maart, april en mei 1983.

De invoering van de werkafspraak voor ECG-aanvragen geschiedde in december 1981. Voor aanvragen voor leverfunctietests gebeurde dit in april 1982. Mede in verband met mogelijke gewenningsfactoren leek het zinvol eerst na verloop van enige maanden de toepassing van deze werkafspraken te meten. In de oorspronkelijke onderzoeksopzet was opgenomen, dat gedurende een periode van drie manden, te weten mart, april en mei 1983, de aanvragen van de huisartsen beoordeeld zouden worden.

* ad derde periode: september, oktober en november 1982.

De navolgende gebeurtenissen gaven aanleiding deze derde periode te meten. Zoals verneld (pagina 34) gingen in de allereerste orienterende fase van het onderzoek de gedachten uit naar een onderzoek over het effect van het geven wan individuele feedback an de huisartsen met betrekking tot hun toepassing van de werkafspraken. Het was de bedoeling dit te doen voor de huisartsen uit de hele regio Mastricht. Directe individuele feed- 
back an slechts een deel van de huisartsen zou beschouwd kunnen worden als een vorm van bevoordeling, terwijl indirecte feedback niet kon worden uitgesloten. Zoals beschreven zou het vanuit deze opzet niet verantwoord zljn, conclusies te verbinden aan de uitkomsten van dit onderzoek ten anzien van de effecten van de gegeven feedback. Door de beleidsgroep van het Experiment Diagnostisch Centrum werd het idee van de individuele feedback evenwel positief ontvangen. In het kader van de evaluatie van het Experiment Diagnostisch Centrum vond $z i j$ het uitermate zinvol individuele feedback beproefd te hebben. Omdat het Experiment Diagnostisch Centrum in januari 1983 zou expireren, diende deze individuele feedback dan wel voor eind 1982 plaats te vinden. Op grond daarvan werd besloten over de maanden oktober, november en december 1982 an de huisartsen individuele feedback te verstrekken. De individuele feed back is gegeven voor aanvragen voor röntgenfoto"s van de lumbosacrale wervelkolom, voor aanvragen ECG en voor aanvragen van leverfunctietests.

Het was warschifnlijk, dat door deze individuele feedback aan de huisartsen de toepassing van 'onze' werkafspraken voor aanvragen ECG- en leverfunctietests beinvloed zou worden. Het was mogelijk, dat de huisartsen door de feedback de werkafspraken ofwel meer, ofwel minder zouden gaan toepassen. ook was het niet uitgesloten, dat de verschillen tussen de huisartsen in de toepassing van de werkafspraken zouden toenemen, dan wel zouden verminderen. Op grond hiervan besloten we eveneens een drie mandse periode te beoordelen voorafgaand aan het geven van de individuele feedback. De eerste feedback werd eind november 1982 over de mand oktober 1982 aan de huisartsen verstrekt. De drie maanden september, oktober en november 1982 zijn derhalve niet of nauwelijks door de feedback-verstrekking beinvloed.

* ad vierde periode: december 1982, januari 1983.

In het kader van de individuele feedback zijn de maanden december 1982 en januari 1983 eveneens afzonderlijk beoordeeld. 
- de keuze van de hoeveelheid onderzoeksanvragen.

Van de mogelijkheid aanvragen voor ECG en leverfunctietests bij het Diagnostisch Centrum te doen werd door de huisartsen in quantitatief sterk wisselende mate gebruik gemakt. op grond hiervan diende een keuze gemakt te worden omtrent de hoeveelheid onderzoeksaanvragen welke door één huisarts minimal aangevraaga diende te zijn, zodat zijn mate van toepassing statistisch verantwoord bepaald kon worden.

Bij de berekening van de percentages aanvragen in overeenstemming met de werkafspraken is het aantal aanvragen van belang. Indien een huisarts in een bepaalde periode $n$ aanvragen heeft gedaan, warvan er $\mathrm{k}$ in overeensteming zijn met de werkafspraken, dan is een schatting van het percentage aanvragen in overeenstemming met de werkafspraken $(k / n) \times 100$. Belangrijk is echter na te gaan hoe nauwkeurig zo'n percentage is. Een 958 (conservatief) betrouwbaarheidsinterval voor het onbekende percentage $p$ wordt gegeven door de formule (Noether, 1976):

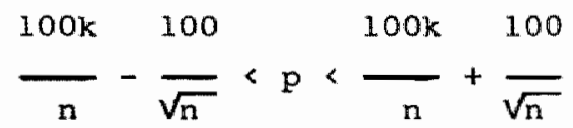

Uit deze formule blijkt dat de nauwkeurigheld ongekeerd evenredig is met de wortel van het aantal aanvragen in een bepaalde periode. Hoe meer aanvragen er zijn gedaan, des te groter de nauwkeurigheid. De vraag die volgde was dan ook: welke minimale hoeveelheid aanvragen kan statistisch verantwoord als criterium gelden? Hoe hoger de hoeveelheid aanvragen als selectiecriterium, des te kleiner vanzelfsprekend de geselecteerde groep huisartsen.

Het gevar dreigde hier, dat het criterium "hoeveelheid aanvragen" een te groot stempel zou drukken op de keuze van de uiteindelijk te selecteren groep huisartsen. Het doel van het onderzoek is echter na te gaan of er factoren zijn die verklaren, waarom huisartsen de werkafspraken al dan niet toepassen. Het gat hierbij dus om groepen huisartsen, bij wie de toepassingspercentages van de werkafspraken redelijk ver uit elkaar liggen. 
Op grond van deze overwegingen hebben wij het daarom verantwoord gevonder het criterium > 50 aanvragen te hanteren en niet het statistisch betere criterium, 100 aanvragen.

Bij gebruikmaking van het criterium > 50 aanvragen wordt de nauwkeurigheid van de berekende percentages in het ongunstigste geval gelijk aan circa $14 \%$ (met een betrouwbarheid "van 95\%). Dit betekent dat bij de indeling van de huisartsen in groepen wat hun toepassingspercentage betreft, de groepen meer dan 14 procent uit elkar dienen te ingen.

- Perioden waarover de toepassingsscores van de huisartsen zijn bepaald.

Zoals beschreven zijn over vier perioden de onderzoeksaanvragen van de huisartsen gemeten, op het toepassen van de werkafspraken: * eerste periode: augustus 1981 ;

* tweede periode: maart, april en mei 1983:

* derde periode: september, oktober en november 1982;

* vierde periode: december 1982 en januari 1983.

Over welke meetperiode werd nu uiteindelijk bepaald in welke mate de huisartsen de werkafspraken toepasten? In de onderzoeksopzet werd in eerste instantie uitgegaan van de driemaandse meetperiode maart, april en mei 1983. Uit de statistische bewerking van de hoeveelheid aanvragen voor alle met het Diagnostisch Centrum samenwerkene huisartsen, van wie het toepassingsperentage is bepald, van alle negen maanden voor de vier meetperioden, valt af te leiden dat de hoeveelheid aanvagen van de huisartsen over de drie manden mart, april en mei 1983, gezamenlijk gemiddeld 33 aanvragen bedraagt (zie tabel 4.3.). Voor de driemandse meetperiode september, oktober en november 1982 bedraagt dit 31 . 


\begin{tabular}{|c|c|c|c|c|c|c|c|c|c|}
\hline \multicolumn{2}{|l|}{ TABEL 4} & $\begin{array}{l}\text { Besch } \\
\text { aanvi } \\
\text { tests }\end{array}$ & $\begin{array}{l}\text { i jue } \\
\text { gen } \\
\text { onder }\end{array}$ & $\begin{array}{l}\text { de } \\
\text { voor } \\
\text { oek }\end{array}$ & $\begin{array}{l}\text { atist } \\
\text { CG-on } \\
\text { n } 74\end{array}$ & $\begin{array}{l}\text { exzoe } \\
\text { isat }\end{array}$ & $\begin{array}{l}\mathrm{a} \\
\text { sen. }\end{array}$ & $\begin{array}{r}\text { hoe } \\
\text { lever }\end{array}$ & $\begin{array}{l}\text { eelheid } \\
\text { anctie- }\end{array}$ \\
\hline & aug. & $\begin{array}{l}\text { sep. } \\
182\end{array}$ & $\begin{array}{l}\text { okt. } \\
182\end{array}$ & $\begin{array}{l}\text { nov. } \\
82\end{array}$ & $\begin{array}{l}\text { deo. } \\
\text { '82 }\end{array}$ & jan. & $\begin{array}{l}\text { mrt. } \\
\cdot 83\end{array}$ & $\begin{array}{l}\text { apr. } \\
183\end{array}$ & $\begin{array}{l}\text { mei } \\
183\end{array}$ \\
\hline emidaelde & 9 & 11 & 10 & 10 & 10 & 9 & 13 & 10 & 10 \\
\hline $\begin{array}{l}\text { Mediaan } \\
\text { Standaard }\end{array}$ & 6 & 8 & 9 & 8 & 8 & 8 & 13 & 9 & 10 \\
\hline afwijking & 9 & 9 & 8 & 9 & 10 & 6 & 10 & 8 & 8 \\
\hline Minimum & 0 & 0 & 0 & 0 & 0 & 0 & 0 & 0 & 0 \\
\hline aximum & 32 & 43 & 31 & 45 & 64 & 20 & 38 & 33 & 38 \\
\hline
\end{tabular}

Bij de vaststelling van de keuze van de hoeveelheid onderzoeksaanvragen werd beargumenteerd, dat we bij het bepalen van de toepassingsscore dienden uit te gaan van meer dan 50 aanvragen. op grond hiervan bevatte een driemandse periode derhalve gemiddeld te weinig onderzoeksaanvagen.

Elders werd beschreven dat de toepassing van de werkafspraken in de oorspronkelijk geplande periode maart, april en mei 1983, mogelijk beinvloed is door de individuele feedback. Toch besloten we van deze periode in eerste instantie uit te gaan, omdat deze periade vrijwel direct vooraf ging aan het tijdstip van het houden van de enquête (juni 1983). Op deze wijze was er een zo groot mogelijke relatie tussen het bepalen van de toepasingsscore en de verzameling van de enquête-gegevens met betrekking tot de variabelen hierop van invloed.

Uitgaande van de driemaandse periode mart, april en meil 1983, kwam de vraag naar voren of het verantwoord zou zijn de aanvragen van de maanden september 1982 tot en met januari 1983 mee te tellen bij het bepalen van het percentage toepassing in overeensteming met de werkafspraken van de huisartsen. Indien dit mogelijk zou zijn, zou het gemiddeld antal aanvagen per huisarts over de totale meetperiode (acht manden) ongeveer 83 bedragen. Hierdoor zou de nauwkeurigheid van de percentages gemiddeld stijgen van (circa) $17 \%$ nar (circa) 11 ${ }^{\circ}$, hetgeen een goede verbetering zou zijn (zie tabel 4.4.). 
TABEL 4.4

Nauwkeurigheid toepassingspercentages voor de perioden maart $1983 \mathrm{t} / \mathrm{m}$ mei 1983 en september $1982 \mathrm{t} / \mathrm{m}$ mel 1983 (met een betrouwbarheid van 958)

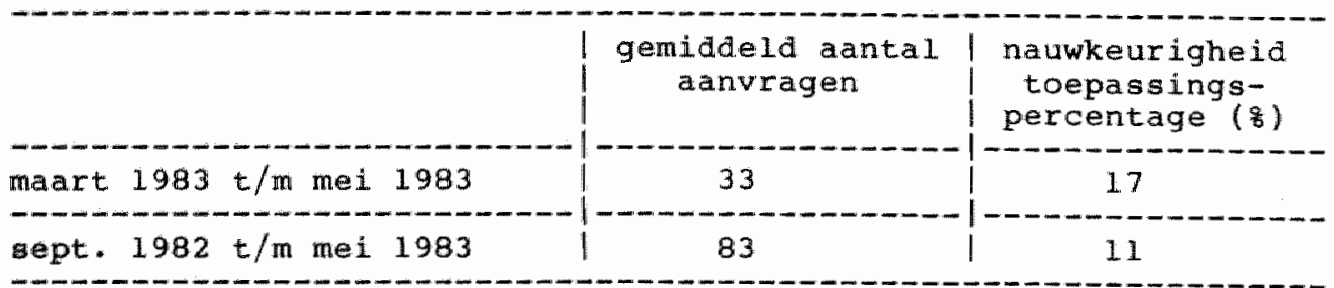

Deze uitbreiding van de meetperiode van matet tot en met mei 1983 naar september 1982 tot en met mei 1983 zou geoorloofd zijn, indien zou blijken dat er vrijwel geen verschil bestaat, wat betreft de 'plaatstoekenning' van de huisartsen ten opzichte van het gemiddelde in procentuele toepassingsscores tussen de meetperioden maart, april, mei 1983 en de hele meetperiode september 1982 tot en met mei 1983 .

onder plaatstoekenning wordt hier verstaan, de plaats die een huisarts inneemt ten opzichte van het gemidalde (of de mediaan) van de toepassingsscores. De vraag was nu in hoeverre de huisartsen die beneden c.q. boven het gemiddelde (of de mediaan) scoorden in de periode maart, april en mei 1983 dezelfden zijn, die dit scoorden in de meetperiode september 1982 tot en met mei 1983 .

Voor welke van alle 74 huisartsen kon deze vergelijking verantwoord gemakt worden? van een aantal huisartsen was de aanvragenhoeveelheid zo gering (in een aantal gevallen zelfs 0 ) dat voor hen geen statistisch verantwoorde procentuele toepassingsscores berekend konden worden. Daarom werd door ons de navolgende keuze gemaakt: alleen voor die huisartsen, die zowel over de driemaandse periode maart, april, mei 1983 als over de driemaandse periode september, oktober, november 1982, voor ledere periode meer dan 16 onderzoeksaanvragen hadden gedaan, zou deze vergelijking gemaakt worden.

op grond van dit criterium bleven er 50 van de 74 huisartsen over. Hieronder waren 42 huisartsen van de 56 huisartsen, die ook de enquete hadden ingevuld. 
Voor leder van deze 50 huisartsen werd voor elke van de onder meetperiode genoemde manden de procentuele toepassingsscore voor de werkafspraken voor ECG-aanvragen en voor aanvragen voor leverfunctietesten bepaald. Tabel 4.5. toont de statistische bewerking van de toepassingspercentages van de werkafspraken voor deze 50 huisartsen.

TABEL $4: 5$.

Toepassingspercentages van de werkafspraken voor ECG-aanvragen en voor aanvragen leverfunctietesten gezamenlijk van 50 "geselecteerde" huisartsen

\begin{tabular}{lrrrrrrrr} 
& sep. & okt. & nov. & dec. & jan. & mrt. & apr. me \\
& 82 & 182 & 182 & 182 & 183 & 183 & 183 & 83 \\
\hline gemiddelde & 39 & 36 & 52 & 60 & 65 & 71 & 72 & 68 \\
mediaan & 37 & 29 & 50 & 54 & 70 & 78 & 78 & 73 \\
standaard & & & & & & & & \\
afwijking & 22 & 27 & 31 & 28 & 28 & 22 & 22 & 26 \\
minimum & 0 & 0 & 0 & 0 & 0 & 0 & 16 & 0 \\
maximum & 89 & 100 & 100 & 100 & 100 & 100 & 100 & 100
\end{tabular}

Uit deze tabel komt naar voren dat het toepassingspercentage na de aanvankelijk forse stijging over de maanden november, december en januari, daarna vrijwel constant blijft.

Het onderzoek is met name gericht op de relaties tussen de toepassing van de werkafspraken en andere variabelen, welke in de enquete en het interview gemeten werden. Daarom was het gewenst de verdere statistische bewerkingen uit te voeren voor de 42 huisartsen van bovengenoemde 50 huisartsen, door wie de enquéte is ingevuld.

Tabel 4.6. toont de statistische bewerking van de toepassingspercentages over de periode mart 1983 tot en met mei 1983 en september 1982 tot en met mei 1983 voor de 42 bovengenoemde huisartsen. 


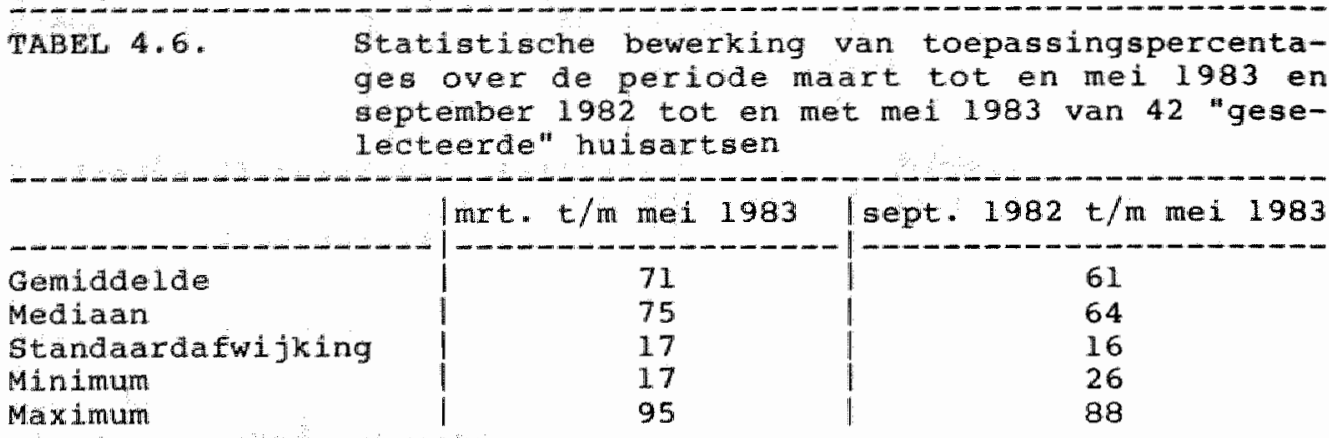

De gemiddelde toepassingspercentages van deze 42 geselecteerde huisartsen vertonen vrijwel geen verschil met de gemiddelde toepassingspercentages van bovengenoemde 50 huisartsen (zie tabel 4.7.).

TABEL 4.7 .

Statistische bewerking van toepassingspercentages over de periode maart tat en mei 1983 en september 1982 tot en met mei 1983 van 50 "'geselecteerde" huisartsen

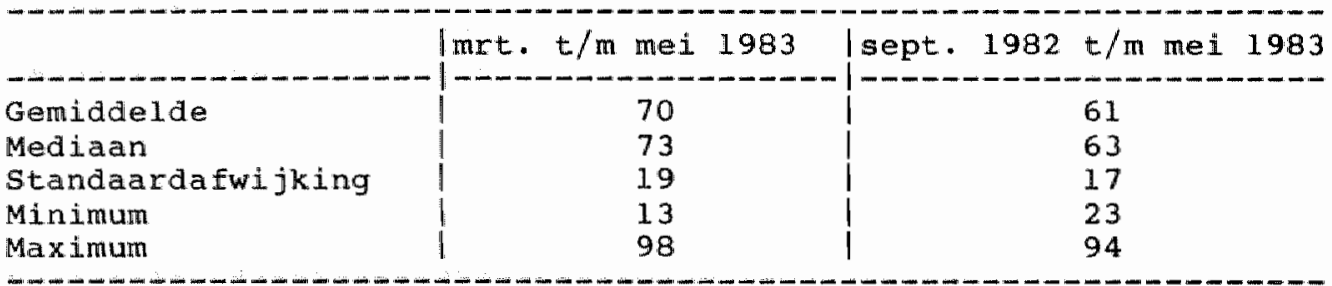

Vervolgens zijn de toepassingspercentages over de periode maart tot en met mei 1983 vergeleken met de toepassingspercentages over de periode september 1982 tot en met mei 1983 voor ieder van bovengenoemde 42 huisartsen afzonderlijk (zie figuur 4.2.). 
FIGUUR 4.2 .

Vergelijking toepassingspercentages over de periodes mart tot en met mei 1983 en september 1982 tot en met mei 1983, voor iedere huisarts. afzonderlijk van 42 geselecteerde huisartsen

september 1982 tot en met mei 1983

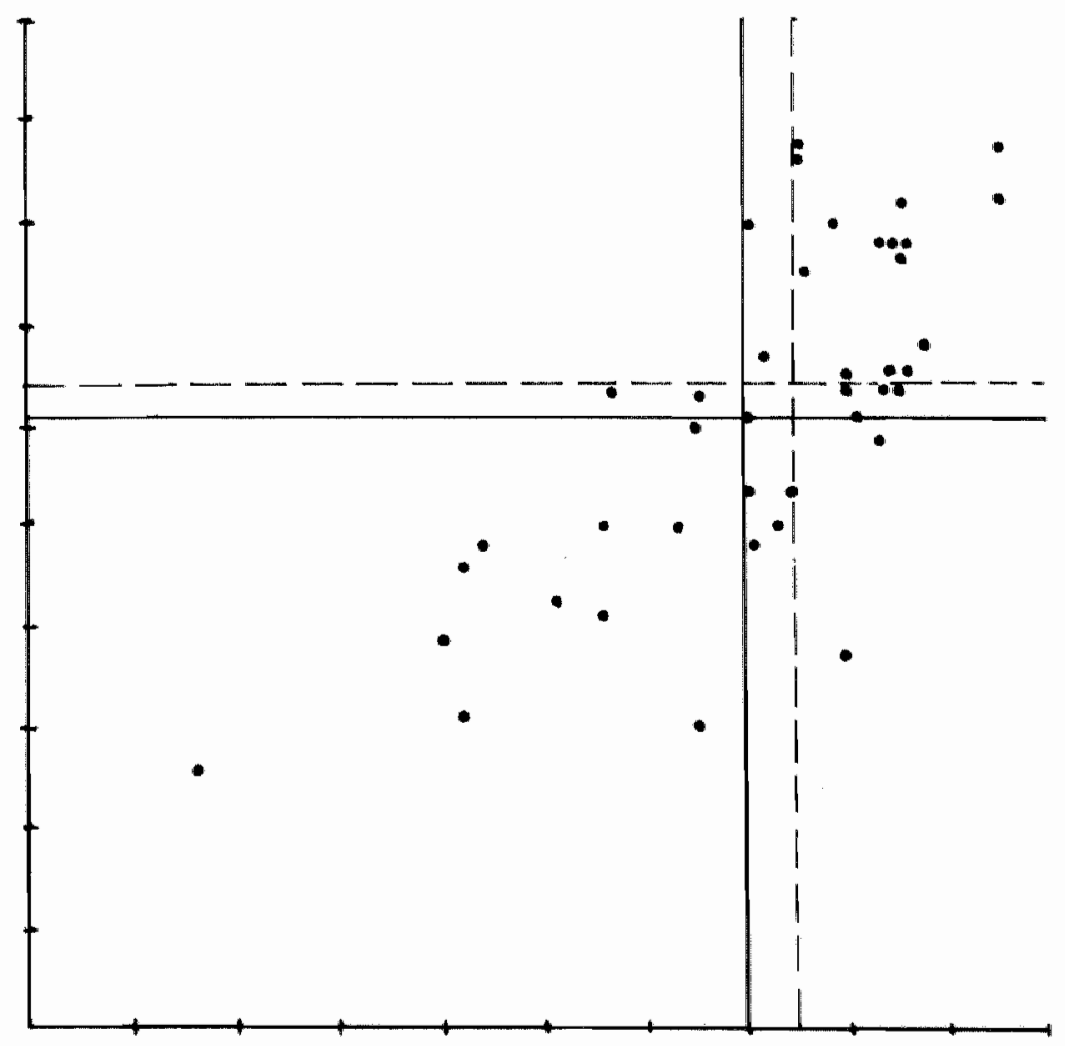

maart tot en met mei 1983

$\longrightarrow$ het gemiddelde van de goedscore

- - - = de mediaan van de goedscore

Zoals vermeld was het van belang na te gaan of er vrijwel geen verschil bestaat, wat betreft de "plaatstoekenning" van de huisartsen ten opzichte van het gemiddelde (of de mediaan) in procentuele toepassingsscores tussen de meetperioden maart, april, mei 1983 en de hele meetperiode september 1982 tot en met mei 1983. Onder plaatstoekenning wordt verstaan, de plaats die een huisarts inneemt ten opzichte van het gemiddelde (of de mediaan) van de 
toepassingsscores. Iedere huisarts kan uiteraard boven of onder het gemiddelde (de mediaan) scoren. De vraag was nu in hoeverre de huisartsen die beneden $c . q$. boven het gemidelde (de mediaan) scoorden in de periode maart, april en meil 1983 en de huisartsen die dit scoorden in de meetperiode september 1982 tot en met mei 1983, dezelfae zijn.

Nemen wij in figuur 4.2. het gemiddelde toepassingspercentage als scheidslijn, dan blijken er in deze zes huisartsen met een laag toepassingspercentage terecht te komen in de groep huisartsen met een hoog toepassingspercentage of omgekeerd. Vanuit het mediaantoepaasingspercentage bezien zijn dit er vijf. In deze zijn de grensposities niet meegerekend.

Eveneens zijn de correlaties berekend voor de toepassingspercentages over de verschiliende meetperioden (zie tabel 4.8.).

TABEL 4.8 .

Correlaties toepassingsscores in verschillende meetperioden, voor 42 geselecteerde huisartsen

\begin{tabular}{|c|c|c|}
\hline PERIODE & AANTAL HUISARTSEN & CORRELATIES \\
\hline september $82-$ mei 83 & & \\
\hline t.o.v. maart $83-$ mei 83 & 42 & 0.78 \\
\hline $\begin{array}{l}82 \text { t.o.v. maart } 83-\text { mei } \\
83\end{array}$ & 42 & 0,49 \\
\hline $\begin{array}{l}\text { september } 82-\text { november } \\
82 \text { t. } 0 . v . \text { september } 82 \\
- \text { mej } 83\end{array}$ & 42 & 0,86 \\
\hline
\end{tabular}

Hieruit blijkt de sterke samenhang tussen de meetperioden september 1982 tot en met mei 1983 en maart 1983 tot en met mei 1983 . voor een deel wordt deze sterke samenhang verklaard doordat de meetperioden voor een deel elkaar overlappen.

Howel de correlatie tussen de meetprioden september 1982 november 1982 en maart 1983 - mei 1983 van beperkte grootte $(0,49)$ is, hebben we het, gezien de hoge correlaties tussen de andere perioden $(0,78$ en 0,86$)$, verantwoord geacht, de toepassing van de werkafspraken te beoordelen over de meetperiode van de maanden september 1982 tot en met mei 1983 . 
4.3.2. Het meten van de factoren van invloed op de toepassing van de werkafspraken

4.3.2.1. De enquete

- De enquete onder alle met het Diagnostisch Centrum samenwerkende huisartsen.

In de definitieve vormgeving is de enquête als volgt onderverdeeld (zie schema 4.4.).

SCHEMA 4.4 .

Globale indeling van de enquete onder huisartsen van Maastricht en omgeving die gebruik maken van het Diagnostisch Centrum.

De toepassing van werkafspraken betreffende diagnostilsche onderzoeken, aangevraagd door huisartsen

I. Mate van appreciatie van het Diagnostisch Centrum door de huisartsen.

A. Appreciatie doelstellingen Diagnostisch Centrum

B. Appreciatie organisatorische opzet Diagnostisch Centrum met betrekking tot praktische werkwijze en communicatie met huisartsen

II. Appreciatie door de huisartsen van protocollen en van werkafspraken i.h.a.

A. Appreciatie van protocollen

B. Appreciatie van werkafspraken

III. Appreciatie door de huisartsen van de werkafspraken vanuit het Diagnostisch Centrum i.h.a.

IV. Appreciatie door de huisartsen van een tweetal werkafspraken vanuit het Diagnostisch Centrum.

te weten:

A. Aanvragen ECG

B. Aanvragen leverfunctietests

V. Kenmerken van de huisarts.

VI. Kenmerken van de praktijk.

VII. Commentaar en aanvullingen ten aanzien van enquête en Diagnostisch Centrum. 
De geinventariseerde factoren zijn grotendeels in de enquete opgenomen. Vanwege het explorerend karakter van het onderzoek zijn de vragen van de enquête deels open en deels gesloten. Een aantal vragen is in eenduidige ja/nee beantwoordingsvorm gesteld. Bijvoorbeeld: Heeft u gebruik gemaakt van de georganiseerde mogelijkheid tot consultatie binnen het Diagnostisch Centrum? ja/nee. Een aantal vragen zijn varuit de ja/nee vorm gestela met daarbij de mogelijkheld tot toelichting. via een toegevoegde open vraag. Daarnaas zijn er veel vragen warin nar een mening van de huisartsen wordt gevraagd, bijvoorbeeld: vindt $u$ vanuit onderstaande redenen het bestaan, respectievelijk de toepassing van de werkafspraken gewenst respectievelijk ongewenst? Naast de mogelijkheid "gewenst" of "ongewenst" in te vullen is ook de mogelijkheid aangereikt om 'geen oordeel' in te vullen. Bij andere vragen is vaak de invulling met 'niet van toepassing' als mage1ijkheid aangeboden. Tenslotte betreffen een aantal vragen appreclatie aspecten. Bijvoorbeeld: Het gebruik van de aanvraagformulieren door het Diagnostisch Centrum hield in dat er gekeken zou worden naar uw diagnostisch handelen. Hoe ervaart u deze controle? Bij vragen als deze is de huisarts beantwoording gevraagd op de volgende vijfpuntsschal:

'positief ++ + + + - - negatief'.

Alvorens de enquête in definitieve vorm werd aangeboden aan de huisartsen is ze in conceptvorm aan een aantal huisartsen ter invuling aangereikt. Deze huisartsen is gevraagd vanuit de navolgende aanachtspunten het invulien van de enquête te evalueren:

- invulling enquête als zodanig;

- welke vragen niet zinvol?

- welke vragen overbodig?

- welke vragen onduidelijk?

- welke belangrijke vragen vergeten?

- bil welke vragen gaven de gebruikte antwoordcategorieên geen adequate antwoordmogelijkheid? 
- in hovevere is de vragenlijst te lang en zo ja welke vragen zouden geschrapt moeten worden?

- eventuele andere opmerkingen.

Hun kritische kanttekeningen zijn in de definitieve versie van de enquête verwerkt. Het probleem van de mogelijk te grote uitgebreidheid van de enquête hebben we trachten op te vangen door in de ambiedingsbrief de nuisartsen hierop te wijzen en hen aan te raden de enquête in een aantal fasen in te vulien.

De enquête is uiteindelijk vanuit het Diagnostisch Centrun aan alle van het Diagnostisch Centrum gebruik makende huisartsen ter invuliing a angeboden (zie bijlage II).

- De enquête onder een referentiegroep van Nederlandse huisartsen $(n=40)$.

In de enquête hebben een aantal vragen betrekking op de geselecteerde werkafspraken voor aanvragen ECG en aanvragen voor leverfunctietests. Met name gaat het daarbij on de vraag in hoeverre de huisartsen deze werkafspraken inhoudelijk huisartsgeneeskundig accorderen. Als referentiekader voor deze huisartsgeneeskundige beoordeling van de werkafspraken door de met het Diagnostisch Centrum samenwerkende huisartsen, zijn de betreffende vragen van de enquête, eveneens voorgelegd aam 40 huisartsen verspreid over Nederland. Het betreft in deze met name dat gedeelte van de enquête dat handelt over de accordering van de werkafspraken inhoudelijk, huisartsgeneeskundig bezien (deel IV van de enquête). Om enige indruk te krijgen hoe de referentiegroep van huisartsen staat ten opzichte van het gebruik van protocollen en werkafspraken in het algemeen is hun ook verzocht deel II van de enquête in te vuilen. De enquête onder de referentiegroep van huisartsen omvatte derhalve alleen de delen II en IV uit de enquête onder de huisartsen die gebruik maken van het Diagnostisch centrum.

Ter verwerving van de referentiegroep van huisartsen zijn 7 
Nederlandse Universitaire Huisartsinstituten benaderd. Door deze werden 40 namen van huisartsen, betrokken als huisartsopleider bij de beroepsopleiding tot huisarts, aangereikt. Er dient opgemerkt te worden dat deze referentiegroep van huisartsen zeer zeker niet als representatief beschouwd mag worden voor de Nederlandse huisartsenpopulatie. Door hun betrokkenheid bij de beroepsopleidingen op de diverse Universitaire Huisartsinstituten zullen de huisartsen van deze referentiegroep vermoedelijk kritischex het huisartsenvak uitoefenen dan de gewone huisarts. Aan deze 40 huisartsen is de enquête ter invulling toegezonden. Van 31 huisartsen is de enquête ingevuld terugontvangen.

4.3.2.2. Het interview onder alle huisartsen, die met het Diagnostisch Centrum samenwerken.

De verwachting was, dat door het gebruik van de open vragen met de enquete veel informatie over de de toepassing van werkafspraken beïnvioedende factoren verzameld zou kunnen worden. Met de enquête zou het evenwel niet mogelijk zijn antwoord te verkrijgen op de vraag, warom de huisarts in concrete situaties de werkafspraken niet had toegepast. Informatie hieromtrent achtten wij evenwel van groot belang. Die zou echter alleen verkregen kunnen worden door de huisartsen de onderzoeksaanvraagformulieren, warbij zij een werkafspraak niet hadden toegepast, te presenteren en daaraan een interview te verbinden. Op grond daarvan besloten we de huisartsen alsnog te interviewen. Dit interview zou dan tevens een soort 'sleepnetfunctie' kunnen vervulien ten opzichte van de enquête, een sleepnetfunctie in de zin van: zijn er nog factoren ten aanzien van de toepassing van de werkafspraken, welke de toepasing beinvloeden en naar welke in de enquete niet werd gevraagd of warover de huisarts in de enquête geen informatie had kunnen geven?

De interviews zijn aoor ëẻn interviewer afgenomen. Aan iedere huisarts werden tijdens het interview een drie- tot vijftal aanvraagformulieren voorgelegd, warin hij de werkafspraken niet had toegepast. Het interview droeg een gedeeltelijk gestructu- 
reerd karakter, in die zin dat er in ieder interview kort ingegaan is op de navolgende vijf onderwerpen:

- redenen om de werkafspraken in de aangegeven situaties niet toe te passen;

- de werkafspraken in het algemeen;

- de invulling van de aanvraagformulieren:

- de verkregen of gewenste feedback;

- de functie en de positie van het Diagnostisch Centrum.

Over het doel en de opzet van het interview was iedere huisarts enige tijd te voren schriftelijk op de hoogte gebracht (zie bijlage III).

4.3.2.3. Algemene gegevens over de huisartsen en hun praktijk.

Bij de factoren van invloed op de toepassing werd één categorie factoren onderscheiden als kenmerken van de praktijk van de huisartsen en één categorie als kenmerken van de huisartsen zelf. Naast de gegevens van de enquête (deel $V$ en VI van de enquête) stonden over deze categorieën bij het Diagnostisch Centrum de volgende gegevens ter beschikking:

- plaats praktijk cq urbanisatiegraad;

- grootte van de ziekenfondspraktijk;

- totale aantal aanvragen per huisarts bij het Diagnostisch Centrum:

- aantal aanvragen voor ECG's;

- aantal aanvragen voor Leverfunctietests;

- aantal verwijzingen naar specialisten poor ziekenfondsvexzekerden:

- aantal verwijzingen naar de cardiologie-afdeling voor ziekenfondsverzekerden;

- aantal verwijzingen naar afdeling interne geneeskunde voor zieken fondsverzekerden.

Aan de huisartsen, die samenwerken met het Diagnostisch Centrum, is door de werkgroep E.D.C.M. schriftelijk de vraag voorgelegd of 
zij er bezwaar tegen hadden, dat in het kader van evaluatieactiiteiten algemene gegevens over de huisartsen zouden worden gebruikt. Door alle huisartsen is dit schriftelijk verzoek met een schriftelijke geen bezwaar verklaring beantwoord. Dankzij deze medewerking waren voor dit evaluatieonderzoek de bovenstaand genoemde gegevens beschikbaar.

Deze gegevens zijn vrijwel alle op groepsniveau gemeten. Als groepsniveau is de indeling van de huisartsen in groepen gebruikt, zoals zij werden ingedeeld wat betreft toepassingspercentage van de werkafspraken.

Op grond hiervan worden deze meetresultaten niet in hoofdstuk 5. bij de onderzoeksresultaten, mar in paragraaf 6.4. onder "Samenhangen gegevens over de toepassing van de werkafspraken met algemene gegevens over de huisarts en zijn praktijk", naar voren gebracht.

\subsection{POPULATIE.}

- De onderzoekaanvragen van 74 met het Diagnostisch Centrum samenwerkende huisartsen zijn op toepassing van de werkafspraken beoordeeld. Elders wordt het getal 67 genoemd. Dit verschil van 7 is als volgt te verklaren. Twee huisartsen namen de praktijk over van een andere huisarts, waardoor de huisartsen van deze praktijken $2 \mathrm{x}$ werden geteld. Drie huisartsen participeerden a an het Dignostisch Centrum als assistent van een huisarts. Eên huisarts was huisarts in opleiding en één huisarts van buiten de regio makt gebruik van het Diagnostisch Centrum. Er waren geen argumenten om deze zeven (huis)artsen niet in het onderzoek te betrekken.

Van alle 74 huisartsen zijn de onderzoeksaanvragen voor ECG- en leverfunctietests over de bij de meetperiode aangegeven maanden In het onderzoek betrokken.

- De enquête is toegezonden aan de 67 huisartsen met een, op het tijdstip van het verwerken van de enquête, vast samenwerkingsverband met het Diagnostisch Centrum. 
- Het interview is gehouden met de 56 huisartsen door wie de enquête is ingevuld.

Bij de diverse bewerkingen en analyses van het onderzoeksmateriaal is er meermalen sprake van een getalsmatige andere huisartspopulatie. In tabel 4.9. Wordt angegeven welke huisartsen tot de verschillende huisartspopulaties behoren en waar zij in het onderzoek naar voren komen.

TABEL 4.9. $\begin{aligned} & \text { Overzicht van de huisartspopulaties in het } \\ & \text { onderzoek }\end{aligned}$

\begin{tabular}{|c|c|c|}
\hline $\begin{array}{l}\text { Aantal } \\
\text { Huis- } \\
\text { artsen }\end{array}$ & $\begin{array}{l}\text { Beschrijuing } \\
\text { Huisartspopulaties }\end{array}$ & Pagina \\
\hline 74 & $\begin{array}{l}\text { Met het Diagnostisch Centrum samenwerkende } \\
\text { huisartsen, van wie het toepassingspercen- } \\
\text { tage is bepaald }\end{array}$ & $\begin{array}{l}73,74 \\
84,88\end{array}$ \\
\hline 67 & $\begin{array}{l}\text { Met het DC samenwerkende huisartsen aan wie } \\
\text { de enquete is toegezonden }\end{array}$ & $\begin{array}{ll}19, & 84 \\
92, & 158\end{array}$ \\
\hline 56 & $\begin{array}{l}\text { Van bowenstaande } 67 \text { huisartsen, de huisartsen } \\
\text { die de enquete invulden }\end{array}$ & $\begin{array}{l}74,88,89, \\
92,93,100 \\
101,109, \\
110,114, \\
132,147 \\
158\end{array}$ \\
\hline 50 & $\begin{array}{l}\text { Van bovenstaande } 74 \text { huisartsen, diegenen met } \\
\Rightarrow 16 \text { onderzoeksaanvragen voor de periode } \\
\text { maart-april-mei } 1983 \text { en sept.-okt. -nov. } 1982\end{array}$ & $74-76$ \\
\hline 42 & $\begin{array}{l}\text { Van bovenstaande } 50 \text { huisartsen, diegenen die } \\
\text { tevens de enquête hebben ingevuld }\end{array}$ & $74-78$ \\
\hline 4 & $\begin{array}{l}\text { Van bovenstaande } 56 \text { huisartsen, die de enquê- } \\
\text { te hebben ingevuld, diegenen met }>50 \\
\text { onderzoeksaanvragen over de periode sept. } \\
1982 \text { tot en met mei } 1983\end{array}$ & $\begin{array}{l}89,90 \\
135, \quad 157\end{array}$ \\
\hline 13 & $\begin{array}{l}\text { Van bovenstaande } 44 \text { huisartsen, de huisartsen } \\
\text { met een hoog toepassingspercentage }\end{array}$ & $\begin{array}{l}90,91 \\
115,132\end{array}$ \\
\hline 16 & $\begin{array}{l}\text { Van bovenstaande } 44 \text { huisartsen, de huisartsen } \\
\text { met een matig toepassingspercentage }\end{array}$ & $\begin{array}{l}90,91 \\
115\end{array}$ \\
\hline 15 & $\begin{array}{l}\text { Van bovenstaande } 44 \text { huisartsen, de huisartsen } \\
\text { met een laag toepassingspercentage }\end{array}$ & $\begin{array}{l}90,91 \\
115,132\end{array}$ \\
\hline 40 & $\begin{array}{l}\text { Referentiegroep van huisartsen, die de } \\
\text { enquete ontvingen }\end{array}$ & $\begin{array}{l}81,82,110 \\
126,158\end{array}$ \\
\hline 31 & $\begin{array}{l}\text { Van bovenstaande } 40 \text { huisartsen, de huisartsen } \\
\text { die de enquete invulden }\end{array}$ & 82,126 \\
\hline 7 & $\begin{array}{l}\text { Met het DC samenwerkende huisartsen met wie } \\
\text { een interview is gehouden en die tevens de } \\
\text { enquête invulden }\end{array}$ & 101,132 \\
\hline
\end{tabular}



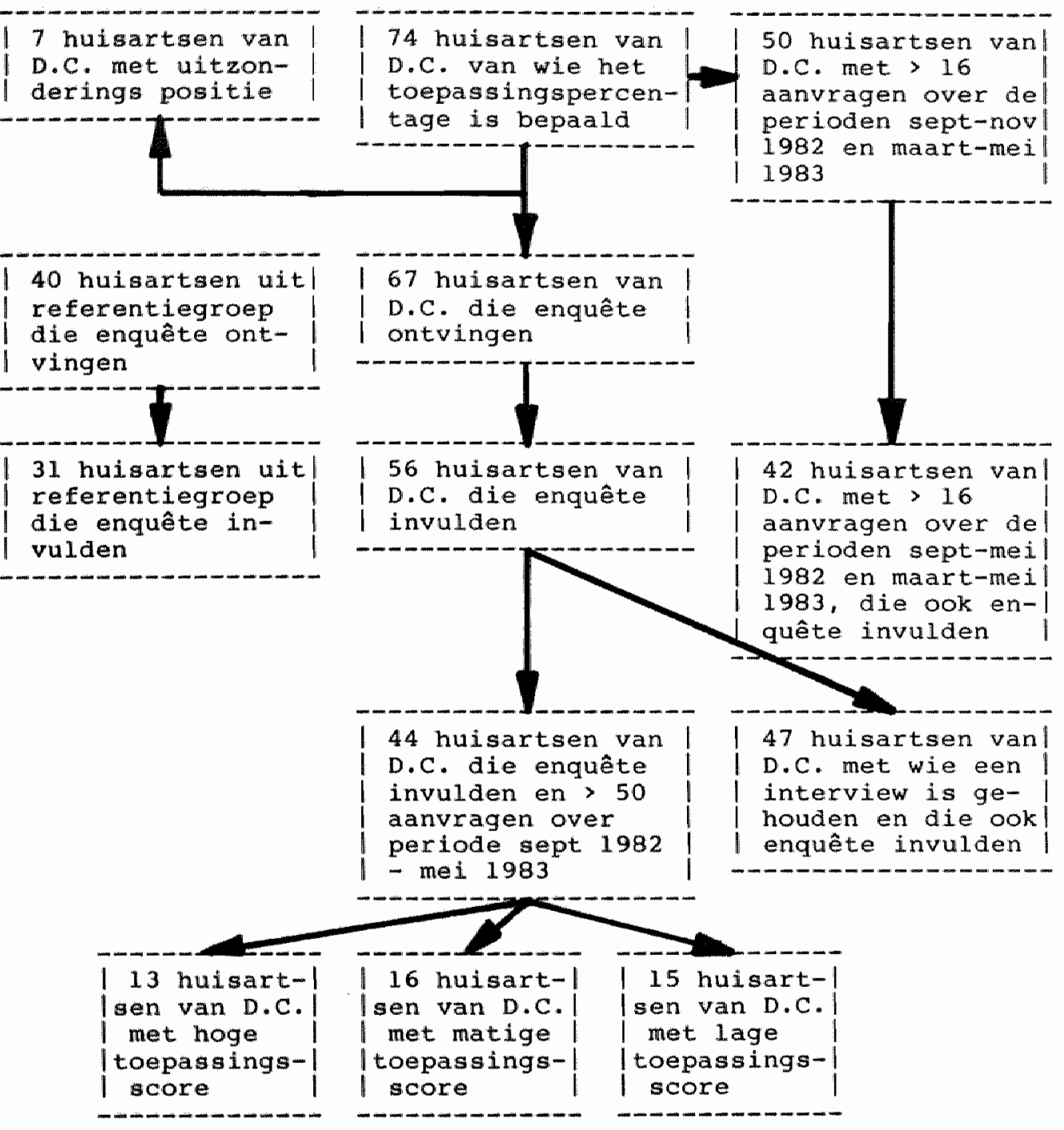


\subsection{HET MEETNIVEAU.}

De gegevens over de toepassing van de werkafspraken zijn gemeten op individueel niveau, evenals het merendeel van de variabelen van invloed op deze toepassing.

Alle variabelen betreffende de huisartsen en de praktijk van de huisartsen zijn, met uitzondering van plats praktijk cq urbanisatiegraad, op groepsniveau geanalyseerd, dat wil zeggen de gemiddelden van de groepen, warin huisartsen worden ingedeeld op basis van hun toepassingsscore van de werkafspraken.

Bij de verdere bewerkingen en analyses van de onderzoeksgegevens zijn twee niveaus te onderscheiden. Enerzijds analyses betreffende alle huisartsen die de enquête invulden gezamenlijk en anderzijds analyses betreffende de huisartsengroepen afzonderlijk, onderverdeeld op basis van hun toepassingsscore van de werkafspraken. De enquête- en de interviewgegevens zijn op beide niveaus bewerkt en geanalyseerd. De algemene gegevens over de huisartsen en de praktijk van de huisartsen zijn alleen verder geanalyseerd op samenhangen binmen bovengenoemde onderscheiden groepen van de huisartsen. 


\section{BESCHRIJVING EN BEWERKING VAN HET ONDERZOEKSMATERIAAL}

5.1. TOEPASSINGSCORES VAN DE WERKAFSPRAKEN EN GROEPSINDELING VAN DE HUISARTSEN.

In deze paragraaf worden de gegevens betreffende de toepassingsscores van de huisartsen gepresenteerd en wordt getoond in welke groepen de huisartsen uiteindelijk zijn onderverdeeld aan de hana van hun toepassingsscores.

De onderzoeksaanvragen van de huisartsen over de maanden september 1982 tot en met mei 1983 werden geanalyseerd naar toepassingsscore.

De analyse van het aantal aanvragen van alle 74 huisartsen, met hantering van de criteria: aantal aanvragen $>25,250,>75$ en > 100 wordt in tabel 5.1 . getoond.

\begin{tabular}{l|l} 
TABEL 5.1. Verdeling van de huisartsen naar aantal aanvra- \\
gen over de maanden september $1982 \mathrm{t} / \mathrm{m}$ mei 1983.
\end{tabular}

De vraagstelling van het onderzoek is na te gaan of er factoren zijn, die verklaren warom huisartsen de werkafspraken al dan niet toepassen. Het gat derhalve met name om de groep huisartsen met redelijk hoge percentages toepassing in overeenstemming met de werkafspraken tegenover de groep huisartsen met tamelijk lage toepassingspercentages.

Hoe de huisartsen mu in te delen in een groep met een hoge toepassingscore en een groep met een lage toepassingsscore? Als extra criterium geldt hierbij dat de huisartsen van deze groepen 
wat betreft hun toepassingsscore tenminste 14 wit elkat dienen te liggen, om zo min mogelijk vermenging van de groepen te krijgen (zie pagina 72 ).

Tabel 5.2. toont de verdere statistische bewerking van het aantal aanvragen met hantering van het criterium: aantal aanvragen $>50$.

TABEL 5.2 .

Statistische bewerking van het aantal aanvragen van de huisartsen bij hantering van het criterium: aantal aanvragen > 50 .

\begin{tabular}{l|c|}
\hline N = aantal huisartsen & 53 \\
\hline Gemiddeld & 106 \\
Mediaan & 98 \\
Standaarddeviatie & 44 \\
Minimum & 51 \\
Maximum & 224 \\
\hline
\end{tabular}

Van de in bovenstaande analyse geselecteerde 53 huisartsen, werd door 44 huisartsen de enquête ingevuld. Dit betekent bijna $80 z$ van de 56 huisartsen door wie de enquête ingevuld werd.

Tabel 5.3. toont de percentages toepassing in overeenstemming met de werkafspraken van de 4.4 geenquêteerde huisartsen met > 50 aanvragen over de 8 maanden: september 1982 tot en met mei 1983 gezamenlijk.

TABEL 5.3

Toepassingspercentage voor de aanvragen over de maanden september $1982 \mathrm{t} / \mathrm{m}$ mel 1983 van de 44 geselecteerde huisartsen.

\begin{tabular}{l|l}
\hline Mantal huisartsen & 44 \\
\hline Gemiddeld & 57 \\
Mediaan & 59 \\
Standaardafwijking & 19 \\
minimum & 11 \\
maximum & 88
\end{tabular}


In de individuele toepassingspercentages van deze 44 hulisartsen zijn, global bezien, een drietal huisartsgroepen te onderscheiden:

- huisartsen met een relatief hoog percentage toepassing in overeensteming met de werkafspraken: toepasingspercentage > $70 \%$

- huisartsen met een tamelijk laag toepassingspercentage: toepassingspercentage < 50\%

- huisartsen met een toepassingspercentage rondom het gemiddelde toepassingspercentage: toepassingspercentage circa $60 \%$.

Vanuit de vraagsteliing van het onderzoek gat het met name om de vergelijking van de groep huisartsen met een hoog toepasingspercentage tegenover de groep huisartsen met een laag toepassingspercentage.

Bij de keuze voor de indeling, op basis van hun toepassingspercentage, van de 44, op een aantal van > 50 aanvragen geselecteerde, huisartsen, zijn een aantal indelingscriteria overwogen. zoals opgemerkt, diende bij de uiteindelijke indeling rekening gehouden te worden met de nauwkeurigheid van de berekende percentages. Deze bedraagt, zoals eerder aangetoond, bij gebruikmaking van het criterium hoeveelheid aanvragen > 50, in het ongunstigste geval zo'n 148 (met een betrouwbaarheid van 95\%).

Bij het gebruik van het indelingscriterium huisartsen met het gemiddeld toepassingspercentage + 2 standaarddeviatie tegenover huisartsen met het gemiddeld toepassingspercentage - $\frac{1}{2}$ standaarddeviatie worden de huisartsen ruimschoots conform deze 148 nawwkeurigheidsintervalsgrens ingedeeld. Bezien we de groep van 44 geselecteerde huisartsen aan de hand van dit criterium, dan wordt de groepsindeling als volgt:

- 15 huisartsen met toepassingspercentage < gemiddeld - $b_{2}$ standaarddeviatie percentage: toepassingspercentage $<57,2$ $b_{2}(18,7)=<47,8$

- 13 huisartsen met toepassingspercentage, gemiddeld $+\frac{1}{2}$ standaarddeviatie percentage: toepassingspercentage $>57.2+$ $18,7)=>66,6$ 
- 16 huisartsen als middengroep: toepassingspercentage tussen 47,8 en 66,6 .

De groepen huisartsen met hoge toepassingspercentages, respectievelijk lage toepassingspercentages liggen 1 standaarddeviatie uit elkaar, hetgeen neerkomt op ongeveer 198. Dit betekent dat in verband met de nauwkeurigheid van de percentages, de kans dat de huisartsen met hoge toepassingsscores in de groep huisartsen met lage toepassingsscores kumnen komen en ongekeerd, kleiner dan 5 o is .

Tabel 5.4. laat de statistische bewerking zien van de toepassingspercentages voor de drie onderscheiden groepen huisartsen.

TABEL 5.4

Toepassingspercentages van de drie naar percentages goedscore onderscheiden groepen huisartsen.

\begin{tabular}{l|c|c|c} 
groep huisartsen & $\begin{array}{c}\text { huisartsen } \\
\text { met laag }\end{array}$ & $\begin{array}{c}\text { huisartsen } \\
\text { met matig }\end{array}$ & $\begin{array}{c}\text { huisartsen } \\
\text { met hoog } \\
\text { percentage }\end{array}$ \\
percentage & $\begin{array}{c}\text { percentage } \\
\text { goedscore }\end{array}$ & goedscore & goedscore \\
\hline N $=$ aantal huisartsen & 15 & 16 & 13 \\
\hline Gemiddelde & 36 & 60 & 79 \\
Mediaan & 38 & 60 & 78 \\
Standaarddeviatie & 11 & 50 & 6 \\
Minimum & 11 & 66 & 88
\end{tabular}

De toepassingspercentages van elke huisarts afzonderlijk, ingedeeld in een van de drie groepen, worden in tabel 5.5. getoond. 


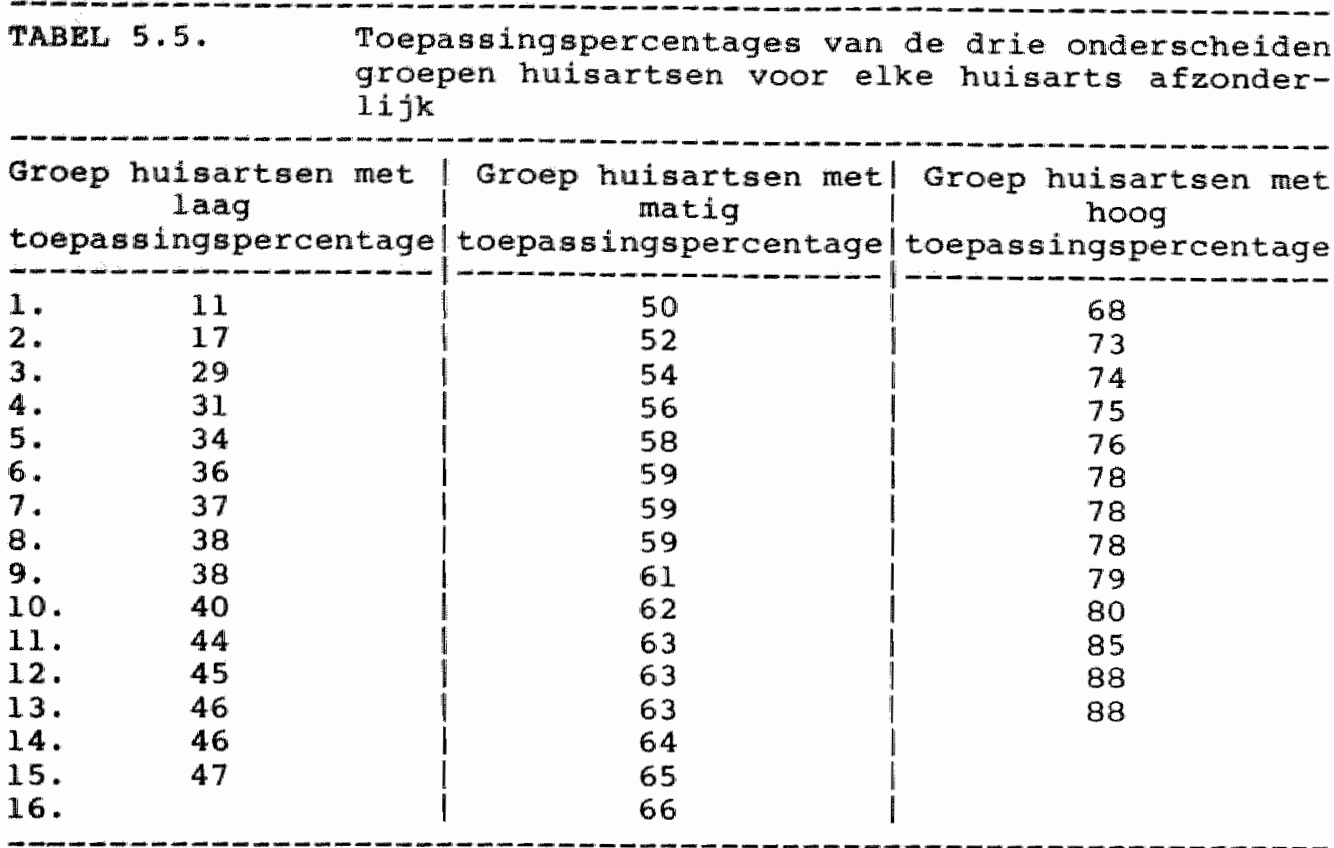

Vanuit deze groepsindeling van de huisartsen zijn vervolgens de enquête- en interviewgegevens geanalyseerd om te bezien of en zo ja, welke factoren discrimineren tussen bovengenoemde groepen huisartsen. De groepen huisartsen zullen we van nu af aan benoemen als:

a. huisartsen met hoog toepassingspercentage;

b. hulsartsen met matig toepassingspercentage;

c. huisartsen met laag toepassingspercentage.

\subsection{DE ENQUETE.}

\section{2 .1 . Inleiding.}

Medio 1983 werd de enquête vanuit het Diagnostisch Centrum aan de 67 huisartsen, die toegang tot het Diagnostisch Centrum hebben, a angeboden. Aan de in eerste instantie niet reagerende huisartsen is vanuit het Diagnostisch Centrum éénmal telefonisch verzocht de enquete alsnog in te vullen. Uiteindelijk is van 56 huisartsen de enquête ingevula terugontvangen. 
Door deze respons (56 van de 67 huisartsen) is in de enquêtegegevens de mening weergegeven van ruim 808 van de met het Diagnostisch Centrum samenwerkende huisartsen. In de in deze paragraaf gebruikte tabellen wordt steeds uitgegaan van deze 56 huisartsen $(=1008)$.

$\mathbb{T} i j d e n s$ het telefonisch verzoek de enquête alsnog in te vullen zijn door een antal huisartsen de beweegredenen nar voren gebracht, waarom zij de enquête niet hadden ingevuld en/of aok niet zouden invullen.

Twee huisartsen gaven als reden aan nooit gebruik te maken van het Diagnostisch Centrum.

Eén huisarts stond op het punt met zijn praktijk op te houden. Twee huisartsen zeiden de enquête niet ontvangen te hebben en ook geen verdere interesse te hebben.

Drie oudere huisartsen gaven te kennen niet aan dit soort nieuwigheden mee te willen doen.

Van de resterende drie huisartsen, die de enquête niet invulden, was één de onderzoeker zelf en van twee huisartsen zijn de motieven onbekend gebleven.

Alle gegevens van de enquête zijn beschikbaar en op te vragen aan de onderzoeker.

De gegevens van de enquête afkomstig van de referentiegroep van Nederlandse huisartsen zullen in paragraaf 6.3. naar voren worden gebracht.

5.2.2. Enquete bevindingen bij alle met het Diagrostigch Centrum samenwerkende huisartsen.

In deze paragraaf zullen de enquête bevindingen worden weergegeven van alle met het Dlagnostisch Centrum samenwerkende hulsartsen en wel aan de hand van de globale indeling van de enquête (zie schema 4.4. op pagina 79). 


\section{MATE VAN APPRECIATIE VAN HET DIAGNOSTISCH CENTRUM.}

Voorafgand aan de vragen over de appreciatie van de Diagnostisch Centrum-doelstellingen begon de enquête met de vraag nar de mening betreffende de ontwikkelingen, die de huisartsen de laatste tien tot twintig jaar in toenemende mate in stat hebben gesteld gebruik te maken van diagnostische faciliteiten, zoals uitgebreid laboratoriumonderzoek, röntgenonderzoek, EcG-onderzoek, enzovoorts. Alle hulsartsen geven aan hier zeer positief (circa 908) of positief (circa 108) tegenover te staan.

\section{- Centrale coörainatie van alle diagnostische aanvragen.}

Ongeveer $85 \%$ van de huisartsen vindt dat de centrale coördinatie van alle diagnostische aanvragen zowel voor henzelf als ook voor de patient alleen maar voordelen heeft. De overige 15 meent, dat hier zowel voor- als nadelen aan verbonden zijn.

- Beoordeling doeltreffend gebruik van diagnostische faciliteiten.

Het gebruik van de aanvraagformulieren en de daaruit voortvioeiende "controle" wordt slechts door én huisarts als negatief ervaren. Enkele huisartsen staan hier ambivalent tegenover.

Door bijna $90 \%$ van de huisartsen wordt deze controle als "zeer positief" gewardeerd.

Bijna $85^{\circ}$ van de huisartsen bevestigt, dat door deze "controle" een meer doeltreffend en meer doelmatig gebruik van de diagnostische faciliteiten, inderdaad wordt bewerktstelligd.

ongeveer $80 \%$ vindt, dat het Diagnostisch Centrum ertoe heeft bijgedragen, dat zij de patienten langer "in eigen hand" kunnen houden.

Door ruim 858 van de huisartsen wordt aangegeven, dat het Diagnostisch Centrum ertoe heeft bijgedragen, dat zij nu meer inzicht hebben in het gebruik van diagnostisch onderzoek dan vroeger. 
- Uitbreiding diagnostische faciliteiten van het Diagnostisch Centrum.

Uitbreiding van de bestaande diagnostische faciliteiten met een aantal voor de huisarts nieuwe diagnostische voorzieningen vindt het merendeel der huisartsen zinvol. Dit geldt voor meer dan $70 \%$ van hen, met name voor allergie-testen, audio metrisch onderzoek en inspannings-ECG. In iets mindere mate gaat dit op voor longfunctie-onderzoek.

- Toe te voegen Diagnostisch Centrum-doelstellingen.

Ten aanzien van aan het Diagnostisch Centrum toe te voegen doelstellingen werden een aantal voorstellen gedaan. De voorstellen zijn in een viertal categorieën in te delen (het aantal voorstellende huisartsen is tussen haakjes vermeld):

- versterking van de eerste 1ijn (12);

- verbetering van de communicatie eerste- en tweede ijn (7);

- vermindering van de verwijzingen naar de tweede lijn (3);

- bezuiniging in de gezonaheidszorg (2).

- Organisatorische opzet Diagnostisch Centrum.

Van de huisartsen vindt het merendeel (bijna 70\%), dat geen zaken in de organisatorische opzet van het Diagnostisch Centrum veranderd behoeven te worden. $20 \%$ geeft kritische bemerkingen. Deze variëren van verbetering van de faciliteiten van het Diagnostisch Centrum in het algemeen tot het vergroten van de contactmogelijkheden met de specialist.

Van de patienten zelf verneemt vrijwel geen huisarts enige kritiek op het organisatorisch functioneren van het Diagnostisch Centrum. 
II. APERECIATIE DOOR HUISARTSEN VAN PROTOCOLLEN EN WERKAFSPRAKEN IN HET ALGEMEEN.

药

- Appreciatie van protocolien.

Naast het toetsen van het eigen handelen (circa 808), alsmede de taakonschrijving van het huisartsgeneeskundig handelen, (75:) worden protocollen door bijna $80 \%$ van de huisartsen gewenst gevonder in relatie tot overleg met en consultatie van de specialist. Financiele motieven (circa 40\%) spelen een beduidend geringere rol. Hetzelfde geldt ten aanzien van juridische factoren (30\%).

- Appreciatie van werkafspraken.

Bij de beoordeling van de wenselijkheid van werkafspraken scoort de werkafstemming van de eerste- en tweede lijn het hoogst (bijna 90\%).

ook de mogelijkheid het eigen handelen te toetsen (ruim 80:) wordt, evenals bij de protocollen, frequent als gewenst motief naar voren gebracht.

III. APPRECIATIE DOOR DE HUISARTS VAN WERKAESPRAKEN VANUIT HET DIAGNOSTISCH CENTRUM IN HET ALGEMEEN.

- Opstellingsprocedure van de werkafspraken.

Ongeveer $30 \%$ van de huisartsen is met de opstellingsprocedure in zijn geheel niet zo gelukkig. Met bepaalde fasen van de opstellingsprocedure is $20 \%$ niet zo gelukkig.

Meer dan $90 \%$ vindt het zinvol, dat de werkafspraken zowel richtlijnen bevatten met betrekking tot de gegevensvermelding op het aanvraagformulier, alsook richtlijnen met betrekking tot zinvolle indicaties voor de onderzoeken.

De accoordverklaring werd gemiddeld door 508 van de huisartsen ingevuld. Bijna 258 van de huisartsen vindt het ondertekenen van de accoordverklaring zinloos. 
Ruim $70 \%$ is van mening, dat het Diagnostisch Centrum bij uit tek in staat is zowel huisartsen als specialisten bij de toepassing van werkafspraken te betrekken. Slechts ëen huisarts stat hier negatief tegenover.

Nog positiever wordt het Diagnostisch Centrum beoordeeld in zijn rol om zorg te aragen voor goede evaluatie van de toepassing van werkafspraken. Meer dan $45 \%$ van de huisartsen beoordeelt dit als zeer positief en bijna $40 \%$ als positief.

IV. APPRECIATIE DOOR DE HUISARTSEN VAN EEN TWEETAL WERKAFSPRAKEN VANUIT HET DIAGNOSTISCH CENTRUM.

Ruim 85\% van de huisartsen vindt zowel de werkafspraak voor ECGaanvragen als voor aanvragen leverfunctietests gewenst.

\section{- Werkafspraak voor aanvragen ECG.}

Voor de ECG-aanvragen werden een zevental zinvolle ináicaties genoemd. Op de vraag of de huisartsen op grond van hun practische exvaringen een of meerdere van deze indicaties zouden willen schrappen of veranderen, antwoordt ongeveer $80 \%$ ontkennend. Wel zouden negen huisartsen nog andere indicaties voor ECG-aanvragen willen toevoegen.

Voor ruim 708 van de huisartsen heeft de ECG-werkafspraak ertoe bijgedragen, dat zij een meer doelmatig gebruik maken van deze diagnostische voorziening bij hun practisch handelen. Ongeveer 508 geeft aan, dat de ECG-werkafspraak ertoe heeft geleid, dat hun verwijzingen naar de cardioloog zijn afgenomen. Voor vier huisartsen zijn deze verwijzingen daarentegen toegenomen. Circa 758 van de huisartsen geeft aan, dat de verwijzingen nar de cardioloog vanuit meer gerichte vraagstellingen platavinden.

\section{- Werkafspraak voor aanvragen leverfunctietests.}

Voor de aanvragen voor leverfunctietests werden de aanvraagindicaties gekoppeld aan een zevental klinische beelden. Ruim $80 \%$ van de huisartsen zou op grond van hun practische ervaring geen van 
deze koppelingen veranderd willen zien. Bijna 858 geeft aan, dat deze werkafspraak heeft geleid tot een meer doelmatig gebruik van deze diagnostische voorziening. Ruim $70 \%$ van de huisartsen vindt. dat ze door deze werkafspraak minder patienten met problematiek op het gebied van leverpathologie naar de specialist verwijzen. Indien zij op dit gebied patienten naar de specialist verwijzen, gebeurt dit volgens bijna $90 \%$ vanuit meer gerichte vraagstellingen.

V. KENMERKEN VAN DE HUISARTS.

- Jaren praktijkervaring.

De eerste vraag in deze betrof het antal jaren huisartservaring van de huisartsen. Zie tabel 5.6 .

\begin{tabular}{lc} 
TABEL 5.6. & Jaren ervaring als huisarts $(8)$ \\
$0-5$ jaar & 25 \\
$6-10$ jaar & 27 \\
$11-20$ jaar & 29 \\
niet ingevuld & 2 \\
\hline totaal & 101 \\
\hline
\end{tabular}

Uit deze tabel. komt naar voren dat meer dan de helft van de huisartsen minder dan tien jaar de huisartspraktijk uitoefent.

\section{- Wijze van samenwerken met andere huisartsen.}

In tabel 5.7 wordt weergegeven op welke wijze de huisartsen al dan niet vanuit een samenwerkingsverband hun praktijk uitoefenen. 
TABEL 5.7

wijzen van samenwerken met andere huisartsen (\%)

geen/incidentele samenwerking 4

in warneemgroep als solist

45

in associatie

in gezondheidscentrum

in associatie in gezondheidscentrum

assistent in gezondheidscentrum

niet ingevula

overige

21

13

4

2

2

11

totaal

102

Bovenstaande tabel toont aan dat minder dan 508 van de huisartsen als solist werkzaam is.

" Betrokkenheid bij onderwijs en research van de Medische Faculteit.

Bijna 70\% van de huisartsen is op de een of andere wijze betrokken bij onderwijsactiviteiten. Dit varieert van continue gestructureerde participatie tot incidentele bijdragen.

Bij research projecten van de medische faculteit is ruim 40 san de huisartsen op enigerlei wijze betrokken.

\section{KENMERKEN VAN DE PRAKTIJK.}

\section{- Praktijkgrootte.}

In de enquete is een zeer ruime indeling voor de praktijkgrootte gehanteerd. Zie tabel 5.8.

\begin{tabular}{lc} 
TABEL 5.8. & $\begin{array}{c}\text { Praktijkgrootte van huisartsen die samenwerken } \\
\text { met het Diagnostisch Centrum ( } 8 \text { ). }\end{array}$ \\
$1500-3000$ & 73 \\
$3000-$ & 16 \\
niet ingevuld & 4 \\
\hline totaal & 100
\end{tabular}




\section{- Hantering kaartsysteem.}

Alle huisartsen op éen na geven aan, een of ander kaartsysteem te hanteren. In ongeveer 60\% betreft dit het kaartsysteem van het Nederlands Huisarts Genootschap. In de overige situaties is door de huigartsen aangegeven, dat zij, of een eigen kaartsysteem, of een problem oriented medical record systeem, of een kaartsysteem van de industrie gebruiken.

\section{- Hantering afspraakspreekuur.}

Door ongeveer $85 \%$ van de huisartsen is aangegeven, dat $z i j$ voornamelijk met een afspraakspreekuur werken.

5.3. HET INTERVHEW ONDER DE HUISARTSEN DIE SAMENWERKEN MET HET DIAGNOSTISCH CENTRUM.

Zoals reeds beschreven nemen de gegevens uit de enquête een centrale plates in bij de gegevensverzameling over factoren van invloed op de toepassing van de werkafspraken. Met het interview is aanvuliende informatie verzameld, met name over factoren welke in het dagelijks practisch handelen hadden geleid tot het niet nakomen van de werkafspraken. Indien bij de eerste interviews specifieke factoren regelmatig aan bod zouden komen, zou naar deze factoren in de hieropvolgende interviews bij de overige huisartsen expliciet gevraagd worden.

De interviews werden door een en dezelfde persoon uitgevoerd. Vanuit het Diagnostisch centrum is in april 1984 het interview bij de huisartsen aangekondigd met een begeleidend schrijven (zie bijlage III). Dit geschiedde alleen bij de 56 huisartsen, door welke de enquête was ingevuld, gegeven de bedoeling van het interview om aanvullende informatie van de huisartsen op de enquête te verkrijgen. 
Het interview is uitelndelijk bij 47 van de 56 huisartsen. die de enquete invulden, afgenomer.

Drie huisartsen gaven te kennen geen tija voor het interview te hebben.

Twee huisartsen hadden inmiddels de huisartspraktijk verlaten.

Eén huisarts was niet bekend met het bestaan van werkafspraken.

Eén huisarts deed vrijwel geen aanvagen bij het Diagnostisch Centrum.

Door twee huisartsen tenslotte werden geen redenen naar voren gebracht on niet aan het interview deel te nemen.

- REDENEN OM DE WERKAFSPRAKEN IN DE AANGEGEVEN SITUATIE NEET TOE TE PASSEN.

In total werden 162 redenen door de huisartsen naar voren gebracht. De redenen zijn onderverdeeld in een vijftal categorieën:

- redenen het Diagnostisch Centrum betreffende;

- redenen het medisch handelen betreffende;

- patientgebonden redenen;

- artsgebonden redenen:

- redenen "derden" betreffend.

Tabel 5.9. laat de procentuele onderverdeling zien binnen deze vijf categorieën van de naar voren gebrachte redenen.

TABEL 5.9 .

Categorisering van de door de huisartsen nar voren gebrachte redenen om in concrete situaties de werkafspraken niet toe te passen ( 8$)$. Total. 162 redenen.

\begin{tabular}{l|l|l|} 
redenen het Diagnastisch Centrum betreffende & 18 \\
\hline redenen het medisch handelen betreffende & 12 \\
\hline patientgebonden redenen & 20 \\
\hline artsgebonden redenen & & 46 \\
\hline redenen "derden" betreffend &
\end{tabular}


Door diverse artsen werden meerdere redenen naar voren gebracht. onderstaand zijn binnen deze 5 categorieèn verdere onderverdelingen weergegeven.

* Redenen het Diagnostisch Centrum betreffende.

Een aantal huisartsen plaatst kanttekeningen bij het functioneren van het Diagnostisch Centrum en hierdoor zijn voor hen redenen (18\%) aanwezig om de werkafspraken niet toe te passen.

Als redenen werden naar voren gebracht:

- het ontbreken van specifieke werkafspraken (88);

- niet alle pathologie is in een werkafspraak te vangen (78);

- de werkafspraken zijn te complex om in de praktijk te hanteren $(3 ;)$.

Bij het ontbreken van specifieke werkafspraken worden als voorbeelden genoemd:

- werkafspraak voor check up;

- werkafspraak voor controle chronische ziekten;

- werkafspraak voor controle medicamenten gebruik.

* Redenen het medische handelen betreffende.

De ervaring dat de werkafspraken als belemmering voor hun medisch handelen worden ondervonden, wordt door de huisartsen slechts in een beperkt antal gevalien a angegeven (12\%). De aangegeven redenen in deze zijn te onderscheiden naar:

- bij patient die je voor het eerst ziet of lang niet gezien hebt, vraag je meer onderzoek aan ;

- in de tekst noem je enkel de hoofaklacht, daar buiten vraag je meer aan :

- bij ernstige, met name complexe pathologie (bv. bij carcinoom of systeemziekte) vraag je meer aan. 
Duidelijk wordt naar voren gebracht, dat de huisartsen vanuit hun inschatting van een klacht, vaak redenen aanwezig achten om meer onderzoek aan te vragen dan in de werkafspraken wordt geadviseerd.

\section{* Patientgebonden redenen.}

De patienten kunnen in een aantal situaties een zekere druk witoefenen op de huisartsen om bepallde medische handelingen te doen. Dit blijkt overigens slechts in een tamelijk gering aantal situaties door de huisartsen te worden naar voren gebracht (20\%). De aangegeven redenen zijn in een tweetal categorieën te verdelen:

- aanvragen zuiver en alleen op aandrang van patient ter geruststelling $(158)$;

- aanvraagformulier wordt onvolledig ingevuld, omdat privacy van patient bedreigd wordt $(58)$.

Als voorbeelden van de bedreiging van de privacy worden genoemd: alcoholgebruik en geslachtsziekten.

Geruststelling van de patient wordt door sommige artsen ook bewust gehanteerd als motief om onderzoek aan te vragen buiten het kader van de werkafspraak.

\section{* Artsgebonden redenen.}

De ondervraagde huisartsen vinden, dat in ongeveer de helft der gevallen ( $46 \%$ ) eigenschappen van henzelf een rol spelen bij hun niet toepassen van de werkafspraken.

- werkafspraak vergeten (9\%);

- slordig invullen van de aanvraagformulieren (9\%);

- tijdsaruk (148);

- door onvolledig invullen van het tekstdeel fout gescoord (8\%);

- routinematig (als vanouds) aanviagen (6\%). 
De tijdsdruk wordt vaak geweten aan de spreekuurarukte. Aanvraagformulieren worden slecht ingevuld of naderhand pas ingevuld. Ook wordt aangegeven, dat zij in een aantal gevalien door de assistente worden ingevuld. Ten aanzien van het onvolledig invullen wordt door een aantal artsen de vraag gesteld of dit niet voortkomt uit het ontbreken van de juiste motivatie.

* Redenen "derden" betreffend.

slechts in een zeer gering aantal situaties worden "derden." arngegeven als redenen om de werkafspreken niet toe te passen (4), namelijk vanwege:

- werkafspraak met anderen;

- aanvragen voor onderzoek op verzoek van anderen (bv. internist, fysiotherapeut, keurend arts, enz....).

Bij de werkafsprak met anderen worden zowel genoemd andere instanties, zoals bijvoorbeeld het Consultatie Bureau voor Alcohol en Drugs (CAD), alsook andere artsen, zoals geassocieerde collegae of specialisten.

- DE WERKAFSPRAKEN VANUIT HET DIAGNOSTISCH CENTRUM IN HET ALGEMEEN.

Uit het interview komt naar voren, dat ruim 70 s van de huisartsen positief stat ten opzichte van de hantering van werkafspraken vanuit het Diagnostisch Centrum.

Naast positieve opmerkingen worden door een aantal van de geinterviewde huisartsen de volgende kritische kanttekeningen geplatat:

- Werkafspraken zijn alleen te zien als richtiijn. Er is enige angat voor te protocollair geneeskundig handelen.

- Werkafspraken zijn toch te zeor samengesteld vanuit specialistisch en te weinig vanuit huisartsgeneeskundig denken. 
- Toepassing van de werkafspraken zal dreigen te verwateren. als er geen feedback wordt verstrekt.

- De werkafspraken zijn voor een deel te ingewikkeld of te complex.

- DE INVULLING VAN DE AANVRAAGFORMULIEREN.

Door een antal huisartsen worden de navolgende kritische bemerkingen geplaatst bij de invulling van de aanvraagformulieren:

- Goede invulling van het tekstdeel kost (te) veel tija. Daardoor raakt dit vaak in de knel door de spreekuurdrukte.

- Tot invuliing van het tekstdeel alleen dan gemotiveerd, als de huisarts verwacht, dat over de onderzoekaanvaag consultatie zal volgen.

- Het rendement van de invulling van het tekstdeel is niet zo hoog alswel zou kunnen bij meer consequente evaluatie van de aanvragen van de huisartsen door het Diagnostisch Centrum.

\section{- DE GEGEVEN OF GEWENSTE FEEDBACK.}

Omdat het geven van de feedback feitelijk buiten het onderzoekskader valt, is er bij de presentatie van de enquêtegegevens voor gekozen de informatie hieromtrent naar voren te brengen in Hoofdstuk 7. Dit zal ook platsvinden voor de informatie over de gegeven of de gewenste feedback, zoals die uit de interviews nat voren kwam.

\section{- PLAATS EN FUNCTIE VAN HET DIAGNOSTISCH CENTRUM.}

Vrijwel alle geinterviewde huisartsen stan positief ( \pm 208 ) tot zeer positief $( \pm 758)$ tegenover het Diagnostisch Centrum.

Door een aantal huisartsen worden hieromtrent opmerkingen gemakt. Hierin komt met name naar voren dat met behulp van Diagnostische centra de huisartsgeneeskunde in stat is zichzelf te versterken, wardoor de huisartsen in meer situaties de patienten kunnen helpen zonder een beroep te moeten doen op andere hulpverleners. Dit geldt vooral voor het zuiver somatisch huisartsgeneeskundig handelen. 
Samenvattend kan gesteld worden, dat met de interwiews voor een deel de alreeds in de enquête naar voren gebrachte redenen worden bevestigd. Daarenboven komen uit de interviews de navolgende zaken naar voren:

- Bij de door de huisartsen naar voren gebrachte redenen warom zij in concrete situaties de werkafspraken niet toepassen, spelen artsgebonden factoren de grootste rol (circa 46z).

- Het merendeel van de huisartsen kent aan het Diagnostisch Centrum een essentiele plaats toe bij het hanteren van werkafspraken. De werkafspraken dienen niet te dwingend noch te ingewikkeld te zijn.

- Om de invulling van de aanvraagformulieren te bevorderen dienen deze verbeterd en vereenvoudigd te worden.

- Het Diagnostisch Centrum als institunt wordt uitermate positief gewardeerd. Continuering, alsmede uitbreiding is wenselijk en wordt als onmisbaar gezien in het kader van de verdere uitbouwing van de huisartsgeneeskunde. 


\section{ANALYSE EN SAMENHANGEN VAN DE ONDERZOEKSRESULTATEN}

\subsection{INLEIDING.}

Bij type onderzoek (paragraaf 4.1.) is beschreven dat het onderzoek door zijn explorerend karakter vrij breed van opzet is. In eerste instantie zijn dan ook veel variabelen in de opzet betrokken. Dit had ten gevolge, dat met name de enquête erg uitgebreid was. Allereerst zullen we bij de bewerking en analyse van de enquêtegegevens bezien of het mogelijk is variabelen in de enquête te groeperen en door deze sommatie van variabelen nieuwe variabelen samen te stellen. In paragraaf 6.2. zal hier nader op worden ingegaan. Vervolgens worden de enquêtegegevens op samenhangen met de toepassing van de werkafspraken door de hulsartsen geanalyseerd. Als referentiekader voor de huisartsgeneeskundige beoordeling van de werkafspraken, zullen de enquêtegegevens van de referentiegroep van Nederlandse huisartsen eveneens hierbij geanalyseerd worden.

In paragraaf 6.3 worden de gegegevens van de interviews geanalyseerd op samenhangen met de toepassing van de werkafspraken door. de huisartsen.

In paragraaf 6.4 vindt dit plaats voor de algemene gegevens over de huisartsen en hun praktijk in relatie tot de toepassing van de werkafspraken.

6.2. BETROUWBAARHEIDSANALYSE VAN DE ENQUETEGEGEVENS EN DE SAMENHANGEN VAN DE ENQUETEGEGEVENS MET DE TOEPASSING VAN DE WERKAFSPRAKEN .

\subsubsection{Betrouwbaarheidsanalyse van de enquetegegevens.}

De hele enquête was in een zevental dellen verdeeld (zie schema 4.4 pagina 79). De variabelen wit deel $V$ en deel VI betreffen de kenmerken van de huisarts en zijn praktijk. Betrouwbaarheidsanalyses op de wijze zoals in het navolgende wordt beschreven zijn voor deze delen $v$ en VI niet van toepassing. Dit geldt eveneens 
voor deel VII van de enquête, omat hierin alleen commentaar en opmerkingen naar voren zijn gebracht. Voor de betrouwbarheidsanalyses resteerden de eerste 4 delen van de enquête. In verband met de verdere statistische analyse werden de vier navolgende bewerkingen van de enquêtegegevens uitgevoerd:

1. Alle variabelen warover informatie werd ingewonnen door middel van open vragen (zoals beschreven in paragraaf 4.3.2.1.) werden geẻlimineerd.

2. De resterende variabelen werden geanalyseerd op eenduidigheid bij de beantwoording. Een aantal vragen werd op grond van dit criterium geêlimineerd (bijvoorbeeld de vraag: Ervaart u in uw praktisch handelen nog andere factoren als stimulerend, respectievelijk als remmend, bij de toepassing van de EcG-werkafspraak?).

3. De overblijvende variabelen werden uniform gecodeerd volgens de regel. dat een hoog codecijfer staat voor positieve waardering van de enquêtevraag en en laag voor negatieve waardering.

4. De beantwoordingscode van alle variabelen werd tenslotte gestandaardiseerd, zodat de beantwoordingen onderling vergelijkbaar werden. Daartoe werd van iedere beantwoordingscode het gemiddelde yan deze vraggbeantwoording afgetrokken en werd deze uitkomst vervolgens gedeeld door de corresponderende standaarddeviatie (zie ook Ghiselli, Campbell, Zedeck, 1981).

Van de oorspronkelijk in deel I tot en met deel IV van de enquête opgenomen 163 variabelen, werden er 51 geëlimineerd op grond van het open karakter van de vraagstelling. Van zeven vragen was de beantwoordingsvorm niet eenduidig. Er resteerden uiteindelijk 105 variabelen.

De delen I, II en IV van de enquête waren onderverdeeld in tweeen. Bij de verdere analyse is dit eveneens gedaan met deel III. Een onderdeel van deel II betreft de variabelen ten aanzien van de opstellingsprocedure van de werkafspraken en de appreciatie van de werkafspraken vanuit een Diagnostisch Centrum. Het andere onderdeel heeft betrekking op de variabelen over de feedback. 
Derhalve waren er 8 onderdelen voor de verdere analyse, die we als volgt benoemden:

1: appreciatie doelstellingen Diagnostisch centrum (appr. doelst. DC) : 17 variabelen;

2: appreciatie organisatorische opzet Diagnostisch Centrum (appr. arg. DC): 13 variabelen;

3: appreciatie protocollen in het algemeen (appr. prot. alg.): 8 variabelen;

4: appreciatie werkafspraken in het algemeen (appr. werkaf. alg.): 7 variabelen;

5: appreciatie werkafspraken vanuit het Diagnostisch Centrum (appr. werkaf. DC): 12 variabelen;

6: feedback: 6 variabelen;

7: accordatie werkafspraak ECG (accor. werkaf. ECG): 21 variabelen:

8: accordatie werkafspraak leverfunctietests (acc.werk.leverf.): 21 variabelen.

op ieder van deze acht onderdelen werd een betrouwbaarheidsanalyse uitgevoerd (Hull et al., 1981). De betrouwbaarheidsanalyse had onder andere tot doel om te onderzoeken, of de gebruikte vragen per deelcategorie tezamen een homogene vragenlijst vormden. Indien dit bevestigd zou worden, was het verantwoord verder te werken met een reductie van de oorspronkelijke 105 variabelen tot bovenstaand aangegeven 8 onderdelen. Als criterium om deze homogeniteit of interne consistentie van de vragenlijst te bepalen is gekozen voor het criterium, dat bekend is onder de nam cronbach's Alpha (Cronbach, 1951): Algemeen worden als warden voor de beoordeling van de hoogte van deze coëficienten gehanteexa:

$$
\begin{aligned}
& \alpha<.50 \text { slecht } \\
& .50<\alpha<.60 \text { zwak } \\
& .60<\alpha<.70 \text { matig } \\
& .70<\alpha<.80 \text { redelijk } \\
& .80<\alpha<.90 \text { goed } \\
& .90<\alpha \quad \text { uitstekend }
\end{aligned}
$$

Deze coëfficient is tevens een ondergrens voor de betrouwbaarheid van de vragenlijst (Lord en Novick, 1968).

Allereerst is de betrouwbaarheldsanalyse uitgevoerd voor alle 5.6 huisartsen, van wie de enquête werd terug ontvangen (zie tabel 6.1.). 
TABEL 6.1 .

Samenvatting van de betrouwbaarheidsanalyses met behulp van Cronbach" Alpha met betrekking tot 8 onderdelen van de enquête.

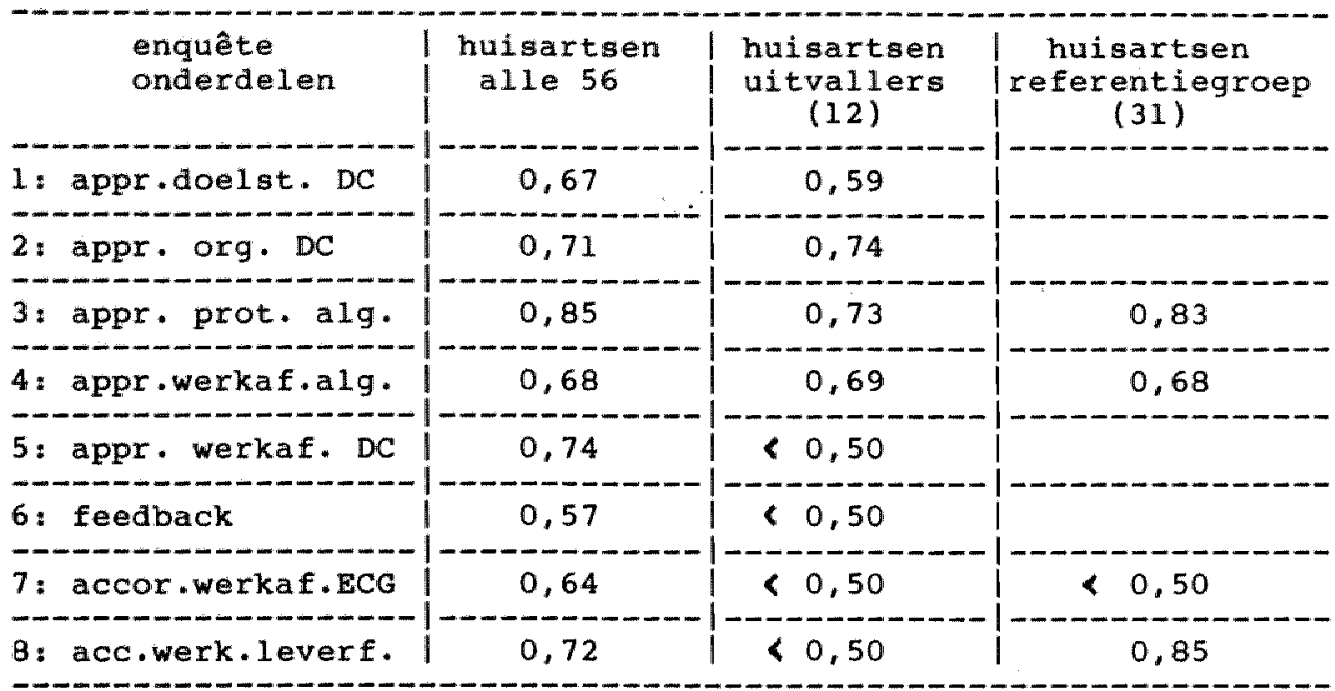

Deze analyse laat zien dat de enquête, zoals deze is ingevuld door de 56 huisartsen, op bijna alle onderdelen matig tot goed betrouwbaar is. De beantwoording van het onderdeel $6^{*}$ (feedback) scoort het laagst met een alpha van 0,57 .

De betrouwbaarheidsanalyse werd op gelijke wijze uitgevoerd (zie eveneens tabel 6.1.) voor de twalf "uitvallende" huisartsen, voor wie het toepassingspercentage niet werd berekend op grond van hun geringe aantal onderzoeksaanvragen (zie paragraaf 5.1.). Het was mogelijk, dat juist door deze "uitvaliers" de enquête minder betrouwbaar was ingevuld, omdat er verschillende redenen konden zijn voor hun geringe aantal onderzoeksaanvragen.

Bij de groep van "uitvallende" huisartsen is de Cronbach"s Alpha over het algemeen inderdaad laag. Dit geldt in het bijzonder voor de onderdelen 5 tot en met 8 van de enquête $(<0,50)$.

Tenslotte is de betrouwbaarheidsanalyse gedaan voor de beantwoording van onderdelen van de enquête door de referentiegroep van Nederlandse huisartsen (zie eveneens tabel 6.1.).

Van de door de referentiegroep van Nederlandse huisartsen beantwoorde enquêtegedeelten is de Cronbach's Alpha alleen voor deel 7 1 aag.

- De hier en verder in deze paragraaf gebruikte aanduidingen verwijzen naar de indeling van de enquête op pagina 109. 
Op grond van de gegevens van de betrouwbarheidsanalyses is besloten verder te werken met reductie van de oorspronkelijke 105 tot bovengenoemde 8 variabelen. Daartoe is een somscore van variabelen toegepast voor de variabelen van de oorspronkelijke subdelen van de enquête en voor de nieuwe subdelen 5 en 6 . Hierdoor werden een achttal nieuwe somvariabelen gevorma: 1 tot en met 8 . Wel dient hierbij opgemerkt te worden, dat het vormen van rechtstreekse somscores problemen opleverde in verband met ontbrekende waarden. Immers door een aantal huisartsen werden sommige enquêtevragen niet of niet adequat beantwoord. Om dit probleem te ondervangen werd een gewogen somscore toegepast volgens de regel, dat per huisarts de som van de gegeven antwoorden alsnog werd gedeeld door het antal geldige antwoorden. Alvorens over te gaan tot het vergelijken van de groepen huisartsen met betrekking tat deze nieuwe somvariabelen werden de nieuwe somvariabelen gestandaardiseerd. Hierdoor werden de diverse somvariabelen met elkaar vergelijkbaar.

De variabelen van de delen $V$ en VI van de enquête zijn, zoals aangegeven op pagina 107, in eerste instantie buiten beschouwing gelaten. Het betreft vragen uit deel $V$ van de enquete over kenmerken van de huisarts en deel VI van de enguete betreffende kenmerken van de praktijk van de huisarts. Dit zijn.met name achtergrondgegevens over de huisarts en zijn praktijk. Ter onderseheiding van de hierboven genoemde somvariabelen zullen we hierbij spreken van achtergrondvariabelen.

Het betreft de navolgende acht achtergrondvariabelen:

- jaren praktijkervaring als huisarts;

- wijze van samenwerking met andere huisartsen:

- betrokkenheid bij onderwijs van de Medische Faculteit;

- betrokkenheid bij een van de research projecten van de Medische Faculteit;

- praktijkgrootte;

- hantering kaartsysteem;

- soort kaartsysteem;

- hantering afspraakspreekuur. 
Een tweetal van deze acht achtergrondvariabelen werd geelimineerd. Allereerst de variabele betreffende de betrokkenheid bij een van de research projecten van de faculteit. De beantwoording van deze vraag verschafte geen extra informatie ten opzichte van de vraagbeantwoording over de betrokkenheid bij onderwijs van de Medische Faculteit. Vervolgens de variabele met betrekking tot het hebben van een kaartsysteem. Door iedere huisarts werd deze vraag met ja beantwoord en derhalve hield deze vraag geen extra informatie in.

Door ons werd nog één achtergrondvariabele toegevoegd. Deze heeft betrekking op de localisatie van de praktijk van de huisarts. In feite gat het om de afstand van de praktijk tot het Diagnostisch Centrum. De localisaties van de huisartspraktijken werden door ons daartoe onderverdeeld in drie categorieën:

- huisartspraktijken in Maastricht gelocaliseerd in de directe omgeving van het Diagnostisch Centrum;

- overige Localisaties van huisartspraktijken in Mastricht:

- huisartspraktijken gesitueerd in plaatsen rondom Maastricht.

Deze variabele werd onder de naam 'regio' toegevoegd.

De achtergrondvariabelen $z i j n$ door ons allereerst gecodeerd. Als leidraad in deze fungeerde onze veronderstelling over de wijze, warop de diverse factoren invloed zouden uitoefenen op de toepassing van de werkafspraken.

positieve beinvloeding is door ons getalsmatig hoog gecodeerd, negatieve interactie werd laag gecodeerd.

voor de 7 achtergrondvariabelen zijn wij, mede aan de hand van de reeds eerdex vermelde literatuurgegevens, uitgegaan van de navolgende veronderstellingen:

9: Ervaring als huisarts.

Pas gevestigde huisartsen zijn, in vergelijking met reeds langer gevestigde hulsartsen, meer geneigd werkafspraken toe te passen, aangezien zij nog niet zo lang geleden opgeleid zijn tot huisarts, onder andere opgeleid in de nieuwe tendenzen, zoals protocollen en werkafspraken. 
10: Wijze van samenwerking.

Huisartsen, die dagelijks intensief samenwerken met collega"s of andere hulpverleners, zullen positiever staan ten opzichte van werkafspraken, waarin samenwerking met specialisten naar voren komt, dan meer afzonderlijk werkende huisartsen.

11: Betrokkenheid bij onderwijs van de Medische Faculteit. De toepassing wan werkafspraken en protocollen wordt met name ook bewerksteligd varuit de hulsartsinstituten van de Medische Faculteiten. Vanuit hun participatie aan onderwijs zullen huisartsen hiertoe gestimuleerd worden.

12: Praktijkgrootte.

Huisartsen met kleinere praktijken zullen vermoedelijk minder praktijkdruk in tija ervaren en aardoor over meer tija beschikken om werkafspraken systematisch toe te passen dan huisartsen met grotere praktijken.

13: Soort kaartsysteem.

Het werken met uitgebreide kaartsystemen zal waarschijnlijk voortvloeien uit de behoefte on systematisch te werken. De toepassing van werkafspraken zal hierop goed kunnnen aansluiten. Huisartsen, die uitgebreide kaartsystemen gebruiken, zullen naar verwachting de werkafspraken meer systematisch toepassen dan huisartsen met gewone kaartsystemen.

14: Afspraakspreekuur.

Huisartsen, die werken met afspraakspreekuur, zullen vermoedelijk minder praktijkdruk ervaren dan huisartsen, die geen afspraakspreekuur hanteren (volle wachtkamers) en daardoor meer in staat zijn werkafspraken systematisch toe te passen.

15: Regio.

Huisartsen met een praktijk in de nabijheid van het Diagnogtisch Centrum zullen vermoedelijk intensiever gebruik maken van het Diagnostisch Centrum dan "meer perifere" huisartsen en zullen daardoor mogelijk ook intensiever betrokken zijn op het Diagnostisch Centrum, zo ook op de toepassing van werkafspraken van het Diagnostisch Centrum.

De benoeming en codering van de zeven achtergrondwariabelen geschiedde als onderstaand aangegeven. Tevens vermeld de gegevens van de enquête zoals zij is ingevuld door 56 huisartsen, die samenwerken met het Diagnostisch Centrum. 


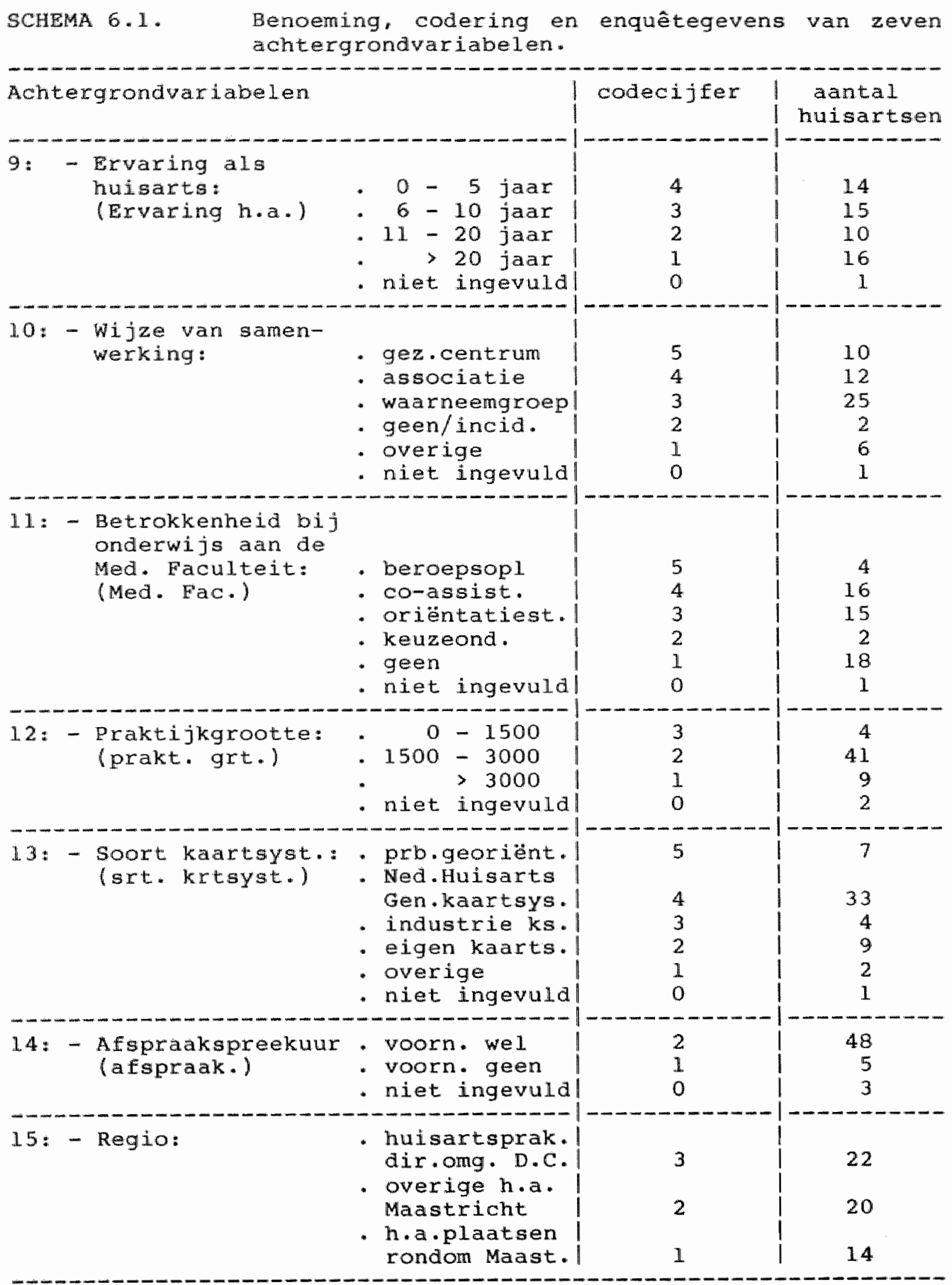


Uiteindelijk ressorteerden uit de enquete 15 variabelen ter werdere analyse op samenhangen met de toepassing van de werkatspraken door de huisartsen, namelijk: acht somvariabelen en zever achtergrondwariabelen.

6.2.2. Samenhangen van de enquetegegevens met de toepassing uan de werkafspraken.

Zoals vermeld in paragraaf 5.1.3. werden de huisartsen ingedeeld in drie groepen:

- huisartsen met een hoge toepassingsscore (13).

- huisartsen met een matige toepassingsscore (16).

- huisartsen met een lage toepassingsscore (15).

De vergelijking tussen de groepen huisartsen is voor de somvariabelen weergegeven in tabel 6.2. en voor de achtergrondvariabelen in tabel 6.3. Eveneens zijn in deze tabellen de overschrijdingskansen tussen de groepen huisartsen weergegeven. Voor de vergelijking van de somscores van de diverse variabelen voor de drie groepen huisartsen gebruiken we de Kruskal-Wallis-toets. Dit is een verdelingsvrije toets, die gebruikt wordt om na te gaan of de groepen alle hetzelfde gemiddelde hebben (zie Noether, 1976). Als we ons beperken tot een vergelijking van de groepen met een hoge en een lage toepassingsscore, is de Mann-Whitney-toets relevant. Deze toets wordt in een twee steekproeven situatie op gelijke wijze gebruikt als de Kruskal-Wallis-toets.

Bij de beoordeling van de overschrijdingskansen is door ons het significantieniveau van 10 gehanteerd. Dit is ons inziens acceptabel gezien het explorerend karakter van dit onderzoek. 


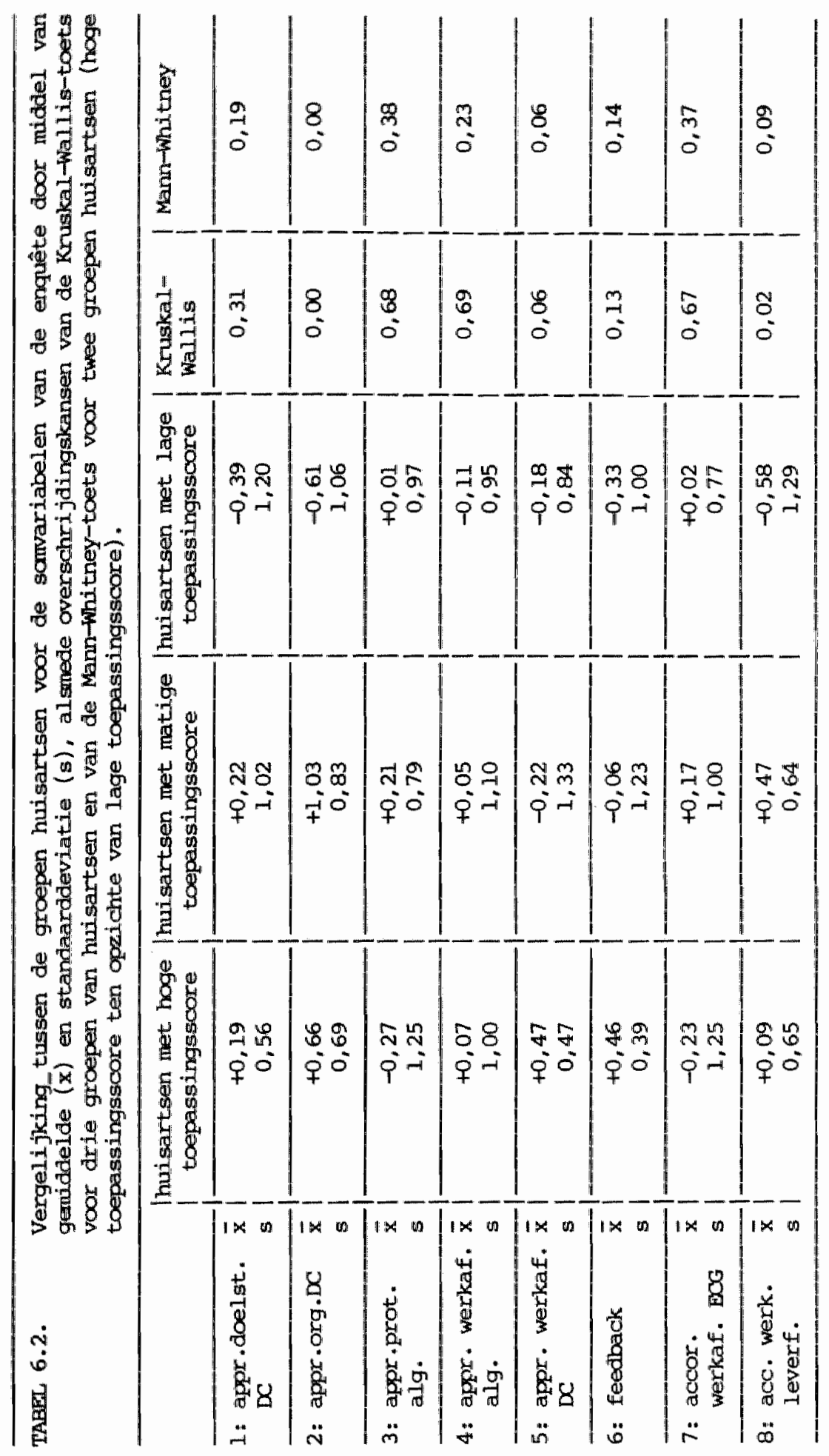




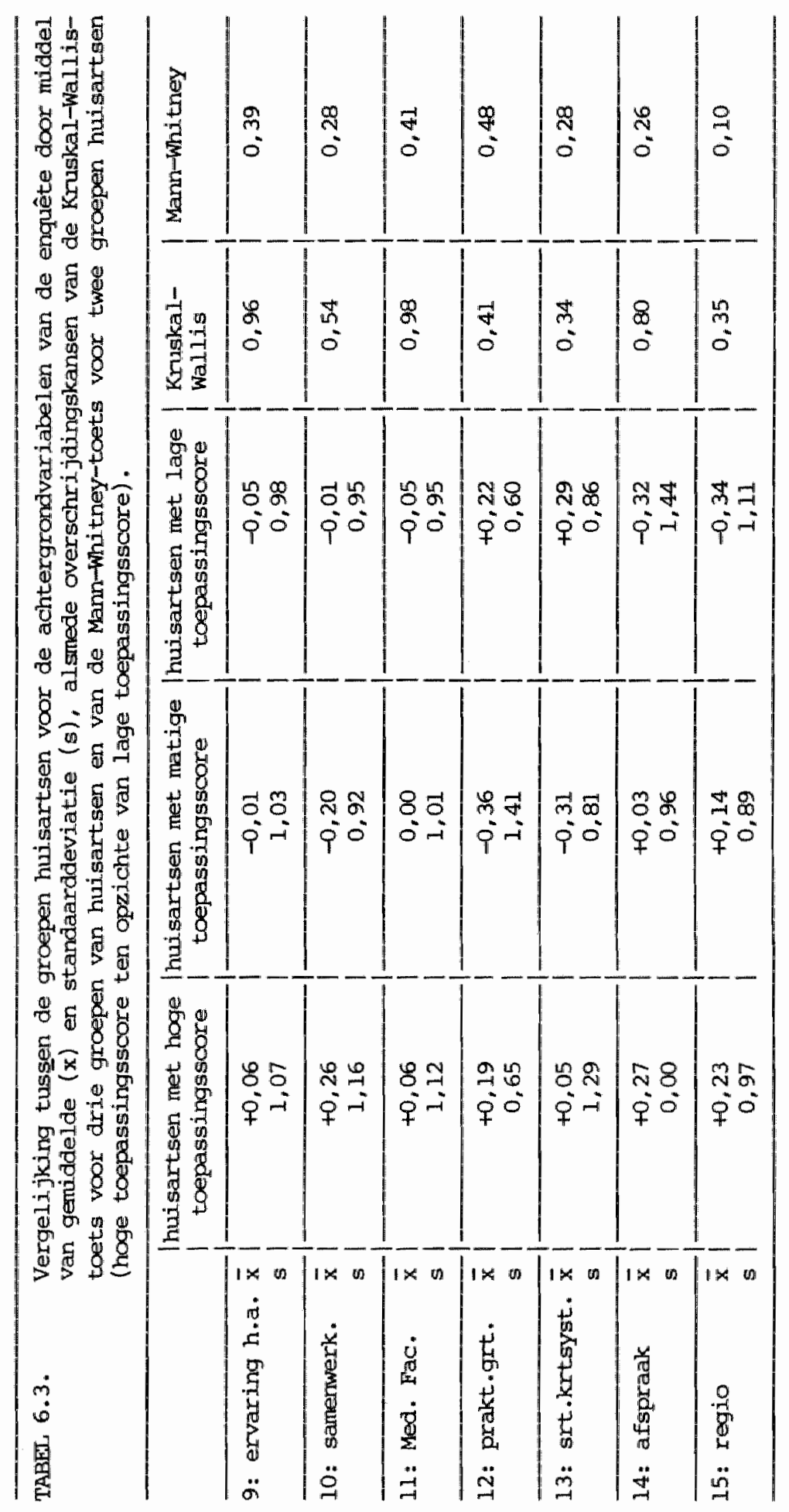


Vanuit de toegepaste codering van de enquete lhoog codecijfer stat voor positieve wardering van het in de enquêtevraag gestelde cq. de toepassing van werkafspraken en laag codecijfer voor negatieve wardering) was het te verwachten, dat de huisartsen met een hoge toepassingsscore van de werkafspraken in deze vergelijking een plusscore zouden behalen, daarentegen de huisartsen met een lage toepassingsscore van de werkafspraken een minscore. Idealiter zouden de huisartsen met een matige toepassingsscore hier tussenin dienen te scoren.

Tabel 6.2. laat zien dat bij de vergelijking voor de somvariabelen de huisartsen met een hoge toepasingsscore inderdaad positief scoren, met uitzondering van de variabele 3 (appreciatie van protocollen in het algemeen) en variabele 7 (accordatie werkafspraak ECG). Voor de huisartsen met een lage toepassingsscore geldt het tegenovergestelde.

Bij de achtergrondvariabelen (zie tabel 6.3.) gaat dit niet op voor de huisartsen met een lage toepasingsscore voor de variabelen 12 (praktijkgrootte) en 13 (soort kaartsysteem).

Opvallend is voor de groepen huisartsen met een lage en een hoge toepassingsscore, dat een appreciatie van werkafspraken in het algemeen blijkbaar niet gepaard gat aan een appreciatie van protocollen in het algemeen. Mogelijk is een verklaring hiervoor, dat door de hulsartsen met een hoge toepassingsscore protocollen als te vergaande richtlijnen worden gezien om ze ook daadwerkelijk toe te passen. Bij de huisartsen met een lage toepassingsscore is hier wellicht sprake van een discrepantie tussen wense$11 j k h e i d$ en werkelijkheid. Eveneens valt op het verschil tussen de groepen huisartsen met een lage en een hoge toepassingsscore ten aanzien van de variabelen over de accordatie van de werkafspraken voor ECG en leverfunctietests. Bij de toepassing van de werkafspraak voor ECG wordt door de groep huisartsen met een hoge toepassingsscore blijkbaar een aantal belemmerende factoren ervaren. Mogelijk is door hen deze werkafspraak ook minder toegepast, doch is dit deels gecamoufleerd door het groter antal onderzoeksaanvragen voor leverfunctietests (bij de scoring van het toepassingspercentage zijn de onderzoeksaanvragen voor ECG en leverfunctietests gezamenlijk beoordeeld). 
De scores van de groep huisartsen met een matige toepassingsscore laten daarentegen een veel sterker wisselend beeld zien ( eveneens tabel 6.2. en tabel 6.3.). Bij de vergelijking voor de somvariabelen scoren zij overwegend positief, met uitzondering van de somvariabelen 5 (appr. werkaf. DC) en 6 (feedback). Bij de vergelijking van de achtergrondvariabelen scoren zij overwegend negatief, met uitzondering van de variabelen 14 (afspraak) en 15 (regio). Blijkbaar bestaat binnen deze groep huisartsen met een matige toepassingsscore een grote divergentie. Enerzijds zijn zij vergelijkbaar met de groep huisartsen met een hoge toepassingsscore (somvariabelen), anderzijds sluiten zij meer an bij de groep huisartsen met een lage toepassingsscore lachtergrondvariabelen). De hieraan ten grondslag liggende redenen zijn ons niet duidelijk. Mogelijk hebben we hier te maken met enigszins ambivalent ingestelde huisartsen. Voor een deel sluiten zij aan bij nieuwe ontwikkelingen in de huisartsgeneeskunde, voor een ander deel zijn zij mogelijk meer behoudend van aard. Ook zou een discrepantie tussen wenselijkheid en werkelijkheid hier wellicht ten grondslag aan kunnen liggen, gezien de lage scores voor de variabelen 5, 6, 10, 12 en 13 (werkelijkheid) en de hoge scores voor de variabelen $1,2,3,4,7$ en 8 (wenselijkheid).

Aan de hand van de overschrijdingskansen (zie tabel 6.2 en 6.3.) van de Kruskal-Wallis-toets bleek dat de gemiddelden van de drie groepen huisartsen significant verschillend waren (op log niveau) voor de variabelen 2,5 en 8 .

Op grond van de overschrijdingskansen voor de twee groepen huisartsen met een hoog en een laag toepassingspercentage (Mann-Whitney-toets) bleken de gemiddelden van de variabelen 2 , 5 , 8 en 15 significant (op 10\% niveau) verschillend te zijn ( $z i$ e eveneens tabel 6.2 . en 6.3.).

On te analyseren welke variabelen de groepen huisartsen het beste onderscheiden, werden hierna discriminantanalyses uitgevoerd tussen de groepen huisartsen aan de hand van de acht somvariabe- 
len en de zeven achtergrondvariabelen. Deze multi-variate statistische techniek biedt de mogelijkheid om verschillen tussen groepen te bestudecen aan de hand van een aantal waarnemingen op diverse variabelen van een steekproef uit deze groepen (Klecka, 1980). Men onderscheidt vaak twee verschillende doelen van discriminantanalyse: interpretatie en classificatie. Bij interpretatie gat het erom inzicht te krijgen in de aard van verschillen tussen groepen. Bij classificatie gaat het veeleer om op basis van metingen op bepaalde variabelen correct (toekomstige) groepsindelingsclassificatie te kunnen voorspelien.

In ons onderzoek wilden we nagaan, welke factoren (variabelen) van invloed zijn op het al dan niet toepassen van werkafspraken. In het vorige hebben we reeds de huisartsen verdeeld in huisartsen met een hoge, matige en lage toepassingsscore. De eerste discriminantanalyse werd uitgevoerd voor de drie groepen huisartsen en alle variabelen.

Omdat het in dit onderzoek met name ging om de vraag in hoeverre de huisartsen met een hoge en een lage toepassingsscore van de werkafspraken van elkaar verschillen, werd eveneens een discriminantanalyse uitgevoerd voor deze twee groepen huisartsen en alle variabelen.

Om te bepalen in hoeverre de discriminantanalyses succesvol zijn geweest. zijn deze analyses geevalueerd met de zogenaamde classi-

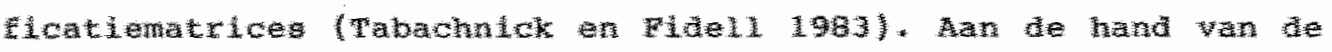

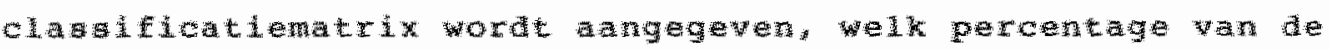

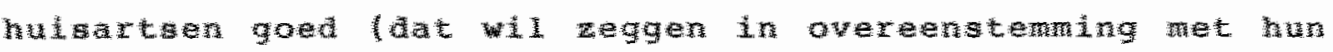

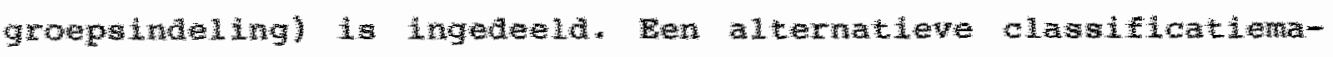

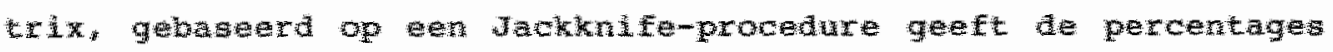

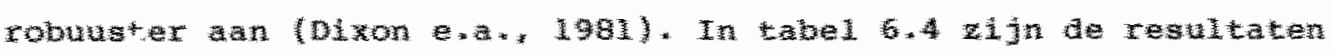

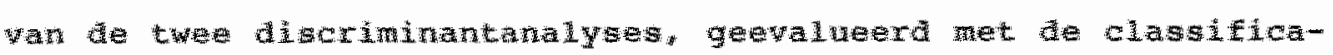

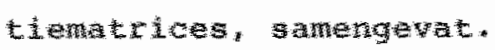


TABEL 6.4.

Classificatie matrix en Jackknife classificatie matrix voor de discriminantanalyses

discriminantanalyse $\mid$\begin{tabular}{c|c|} 
groep & classificatie | Jackknife \\
matrix:* & clasifica- \\
tie:
\end{tabular}

alle variabelen voor

3 groepen huisartsen

alle variabelen voor

2 groepen huisartsen

\begin{tabular}{|l|l|l|} 
laag & 77 & 46 \\
matig & 75 & 38 \\
hoog & 62 & 23 \\
totaal & 71 & 36 \\
\hline laag & 85 & 69 \\
hoog & 92 & 54 \\
total & 89 & 62
\end{tabular}

* percentages goed geclassificeerd

Op grond van de percentages uit de (gewone) classificatiematrix blijkt, dat de drie groepen huisartsen redelijk tot goed zijn te onderscheiden. Op grond van de percentages uit de Jackknife classificatiematrix is dit beeld somberder.

De scheiding van de hulsartsen met een lage en de huisartsen met een hoge toepassingsscore is evenwel goed te maken. De percentages goed geclassificeerd bedragen respectievelijk 85 en 928 en de Jackknife percentages 698 en 548 .

In bovenstaande discriminantanalyses hebben we gebruik gemaakt van alle variabelen.

Van belang is om na te gaan in hoeverre de groepen huisartsen te onderscheiden $\mathrm{zijn}$, indien slechts een beperkt aantal varlabelen gebruikt worden. Om een reductie te bereiken van het aantal gebruikte variabelen hebben we gebruik gemaakt van een zogenaamde stapsgewijze discriminantanalyse. Dat wil zeggen, de variabelen worden successievelijk opgenomen in de discriminantvergelijking op basis van een statistisch criterium. Als criterium is gebruikt de waarde van een F-toetsingsgrootheid (Dixon, 1981). Deze toetsingsgrootheid kan de waarde 0 tot oneindig hebben. De onderzoeker heeft daarbij zelf de keuze, welke waarde hij de toetsingsgrootheid minimal laat hebben, om de variabele al dan niet toe te voegen in de discriminantvergelijking. Door ons werd gebruikt de criteriumwarde 1 . In de eerste stap van de discriminantanalyse wordt die variabele gekozen, die in de discriminantvergelij- 
king het beste voldoet aan het criterium. Vervolgens wordt in de tweede tap uit de overige variabelen, die variabele geselecteerd, die in combinatie met de variabele uit de eerste stap het beste voldoet an het criterium, enz. (zie ook Klecka, 1980). De analyse wordt beeindigd, indien niet meer aan het criterium wordt voldaan. De uit de discriminantanalyse naar voren gekomen volgorde van de variabelen is een prioriteitsrangorde op basis van het criterium en moet dus niet worden opgevat als zijnde een rangorde van belangrijkheid van de diverse variabelen.

Om te bepalen in welke mate de nar voren gekomen variabelen bljdragen aan de bepaling van de scores op de discriminantfunctie, zijn door ons voor deze variabelen de discriminantgewichten (gestandaardiseerde coëfficiënten) bepaald. In de praktijk komt dit erop neer, dat men kijkt naar de absolute warden van het discriminantgewicht. Hoe groter de absolute waarde, hoe groter de invloed van de variabele.

In tabel 6.5 . zijn de resultaten weergegeven van de stapsgewijze discriminantanalyse, waarbij de twee groepen huisartsen met een hoge en lage toepassingsscore, met als controlegroep de groep huisartsen met een matige toepassingsscore, zijn gebruikt en de hierbij behorende discriminantgewichten.

TABEL 6.5 .

Discriminantanalyse, met als criterium F-toetsingsgrootheid 1 , voor alle variabelen van de 2 groepen huisartsen met een hoge en een lage toepassingsscore (met de groep huisartsen met een matige toepassingsscore als controlegroep) en de bijbehorende discriminantgewichten.

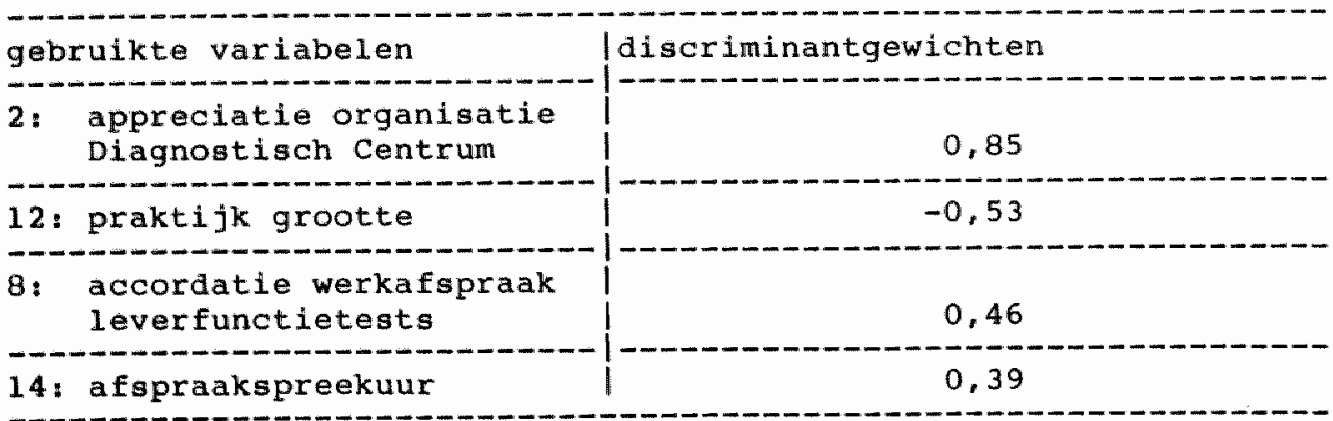


Tabel 6.5. toont, dat de somvariabele 2 het grootste discriminantgewicht bezit. Een positieve appreciatie van de organisatie van het Diagnostisch Centrum gat gepaard met een hoge toepassingsscore. Dit geldt eveneens, zij het in mindere mate, voor de accordatie van de werkafspraak voor leverfunctietests en het hanteren van een afspraakspreekuur. Ten aanzien van de praktijkgrootte blijkt, at zowel de groep huisartsen met een hoge als de groep met een lage toepassingsscore een kleinere praktijkgrootte hebben ten opzichte van de groep huisartsen met een matige toepassingsscore (zie ook tabellen 6.2. en 6.3.).

In tabel 6.6. zijn de gegevens samengevat van de discriminantanalyses voor alle variabelen van de 3 groepen huisartsen en de hierbij bepaalde discriminantgewichten.

TABEL 6.6 .

Discriminantanalyse, met als criterium F-toetsingsgrootheid 1 , voor alle variabelen van de 3 groepen huisartsen met een hoge, matige en lage toepassingsscore en de bijbehorende discriminantgewichten.

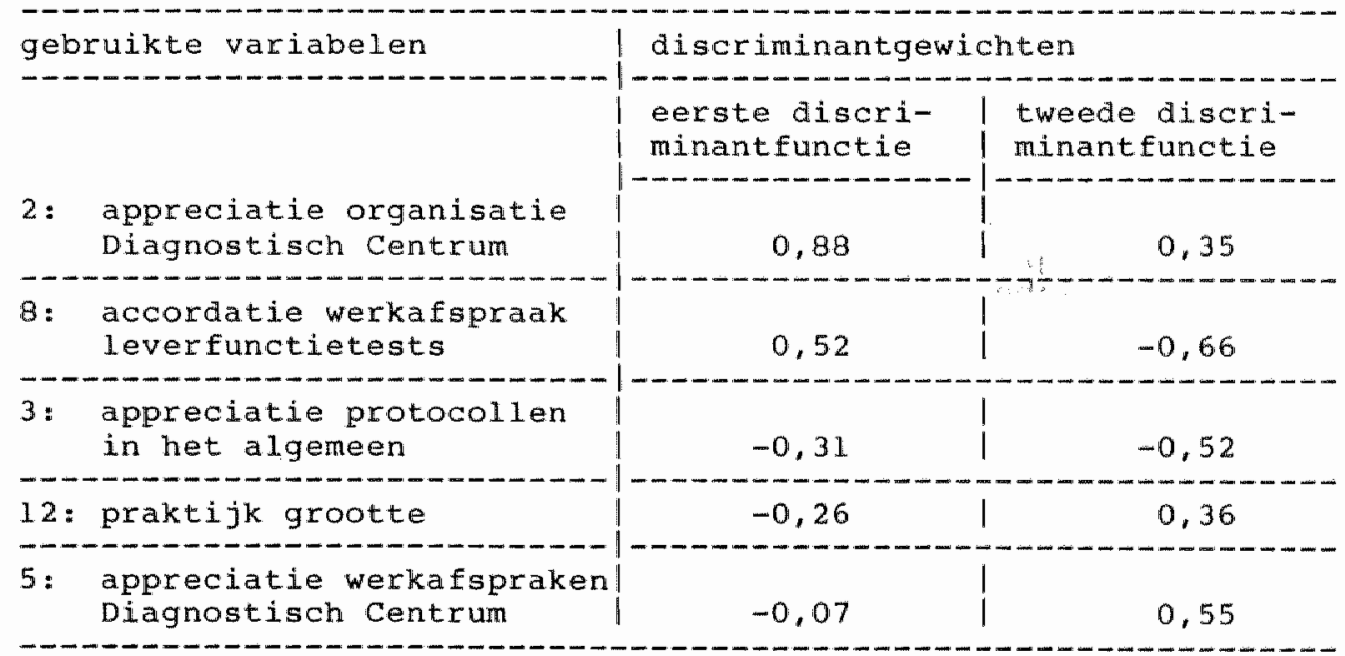

De somvariabele 2 blijkt ook in deze discriminantanalyse het grootste discriminantgewicht te bezitten. Evenals in de discrimimantanalyse voor de 2 groepen huisartsen in tabe1 6.5. bezitten ook nu de somvariabele 8 en de achtergrondvariabele 12 een groot 
discriminantgewicht. Eveneens heeft somvariabele 3 (apprec. prot. i.h.a.) een groot discriminantgewicht. Een hoge toepassingsscore gat gepaard met een negatieve appreciatie van protocollen in het algemeen. zo aok tenslotte somvariabele 5 . Een positieve appreciatie van de totstandkoming van de werkafspraken vanuit het Diagnostisch Centrum gaat gepaard met een hoge toepassingsscore (zie ook tabelien 6.2. en 6.3.).

Vervolgens is door ons nagegaan in welke mate de huisartsen in de groepen zijn in te delen met gebruikmaking van de uit deze discriminantanalyses (zie tabel 6.5. en 6.6.), naar voren komende variabelen. Daartoe zijn door ons van deze discriminantanalyses de classificatie matrix en de Jackknife classisficatie bepald (zie tabe1 6.7.$)$.

TABEL 6.7 .

Classificatiematrices van de discriminantanalyses met als criterium F"-toetsingsgrootheid 1 en bijbehorende gebruikte variabelen

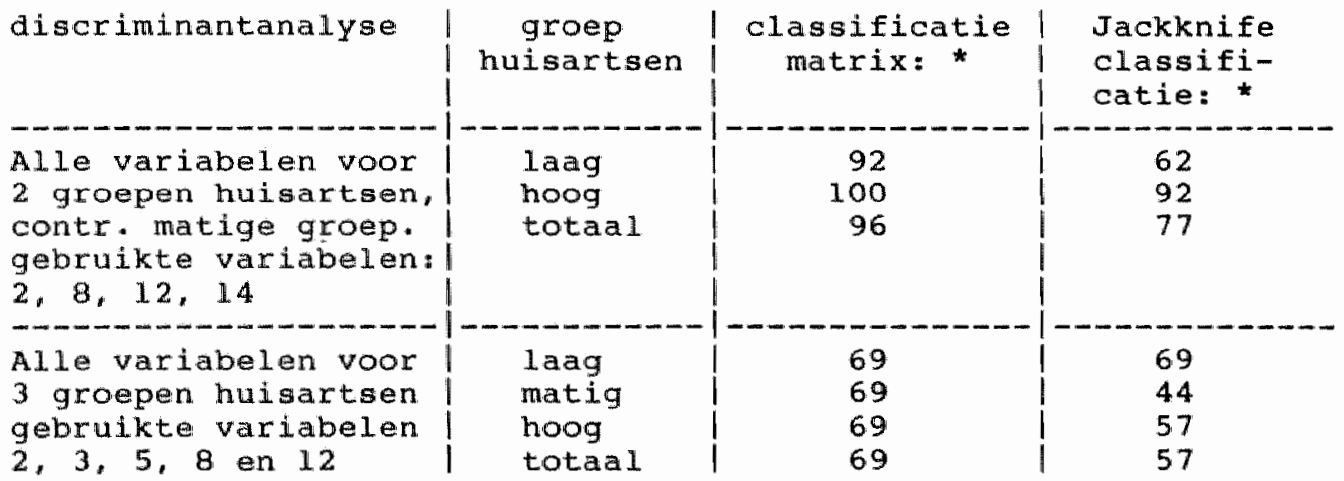

* percentages goed geclassificeerd

Op grond van de percentages uit de classificatiematrices blijkt, dat de 2 groepen huisartsen met een hoog en een laag toepassingspercentage, goed tot zeer goed zijn te onderscheiden.

Uit de classificatiematrices van de discriminantanalyses voor alle variabelen van de 3 groepen huisartsen blijkt, dat de 3 
groepen huisartsen minder goed zijn te onderscheiden. Dit geldt met name voor de groep huisartsen met matige toepassingsscore (448). Dit was ook te verwachten op grond van het reeds gecon stateerde wisselend beeld bij de vergelijking van de variabelen (zie tabel 6.2. en 6.3.).

Van de twee stapsgewijze discriminantanalyses geeft de analyse tussen de twee groepen huisartsen, waarbij de matige groep gebruikt wordt als contrôle-groep ons voor het onderzoek de meest relevante informatie.

Bij alle discriminantanalyses kwam variabele 2 als meest de groepen huisartsen onderscheidende variabele naar voren. Mogelijk oefent deze overheersende positie van variabele 2 een al te grote invloed uit op de overige variabelen. Andere variabelen komen hierdoor mogelijk minder goed nat voren. Dit argument geldt eveneens, maar in mindere mate, voor de somvariabele 8 .

Op grond daarvan was het zinvol de stapsgewijze discriminantanalyses eveneens uit te voeren met uitsluiting van successievelijk variabele 2 en variabele 2 en 8 gezamenlijk.

Uit deze beide analyses kwam nu de variabele 6 (feedback) als meest onderscheidende variabele naar voren.

Samenvattend zijn de navolgende variabelen, in volgorde van discriminerend vermogen, in staat de groepen huisartsen met een hoge en een lage toepassingsscore, mede in relatie tot de groep huisartsen met een matige toepassingsscore, goed te onderscheiden.

Somvariabelen:

2: Positieve appreciatie organisatie Diagnostisch Centrum gat gepaard met een hoge toepassingsscore.

8: Accordatie van de werkafspraak voor leverfunctietests gaat gepaard met een hoge toepassingsscore.

6: Positieve appreciatie van feedback gaat gepaard met een hoge toepassingsscore.

Achtergrondvariabelen:

12: Praktijkgrootte. Zowel de groep huisartsen met een hoge als de groep huisartsen met een lage toepassingsscore hebben in 
vergelijking met de groep huisartsen met een matige toepassingsscore een kleine praktijkgrootte.

14: Het hanteren van een afsprakspreekuur gat gepaard met een. hoge toepassingsscore.

Bij de onderscheiding van de 3 groepen huisartsen blijken, naast de reeds genoemde variabelen 2,8 en 12 , met name de somvariabelen 3 (apprec. prot. i.h.a.) en 5 (apprec. werkat. D.C.) van belang. Een hoge toepassingsscore gat gepaard met een negatieve appreciatie van protocollen in het algemeen en met een positieve appreciatie van de totstandkoming van de werkafspraken vanuit het Diagnostisch Centrum.

In hoofdstuk 8, onder "Samenvattingen en aanbevelingen" zal naar voren gebracht worden, welke ambevelingen aan voorgenoemde analyses verbonden kunnen worden.

\subsection{SAMENHANGEN ENQUETEGEGEVENS VAN HUISARTSEN DIE GEBRUIK MAKEN VAN HET DIAGNOSTISCH CENTRUM EN DE ENQUETEGEGEVENS VAN DE REFERENTIEGROEP VAN NEDERLANDSE HUISARTSEN.}

\section{- Inleiding.}

Als "representant" van de 'andere' Nederlandse huisartsen werden, zoals aangegeven in paragraaf 4.3 .2 .1 . een veertigtal huisartsen benaderd, verspreid over het land. Deze huisartsen waren allen betrokken bij de beroepsopleiding voor huisartsen. Aan hen werden de vragen uit de enquête, betrekking hebbend op de inhoud van de werkafspraken (deel IV A en IV B) voorgelegd. On eveneens een indruk te verkrijgen van de mening van deze huisartsen ten aanzien van het gebruik van protocollen en werkafspraken in het algemeen, werd an hen ook dat gedeelte van de enquete, dat hilerover handelde ter beantwoording voorgelegd (delen II A en II B).

In totaal werd van 31 van de 40 benaderde huisartsen de enquête ingevuld terugontvangen. Onderstaand zullen deze gegevens worden 
weergegeven en geanalyseerd op samenhangen met de enquêtegegevens van de huisartsen, die gebruik maken van het Diagnostisch centrum.

\section{- Bewerkingen en analyse.}

Reeds eerder werd beschreven, dat de betrouwbarheid van de invulling van de enquête door de referentiegroep van huisartsen redelijk tot goed was voor onderdeel II $A$, II $B$ en IV $B$, maar laag voor IV A (zie tabel 6.1.).

Om na te gaan of de gemiddelden van de vier variabelen al dan niet verschillend $z i j n$ voor de vier groepen huisartsen (de groepen huisartsen met een hoge, matige, lage toepassingsscore en de referentiegroep van huisartsen), werd eveneens gebruik gemakt van de Kruskal-Wallis toets. In tabel 6.7. zijn de overschrijdingskansen gegeven.

\begin{tabular}{l|c} 
TABEL 6.7. & $\begin{array}{l}\text { Overschrijdingskansen volgens } \\
\text { tussen referentiegroep van huisartsen en de drie } \\
\text { groepen huisartsen voor vier somvariabelen. }\end{array}$ \\
\hline Somvariabelen & Overschrijdingskans \\
\hline 3: (protocollen) & 0,78 \\
4: (werkafspraken) & 0,88 \\
7: (ECG) & 0,00 \\
8: (leverfunctietesten) & 0,00
\end{tabular}

Bij de beantwoording van de vragen van de somwariabelen 7 en 8 zijn significante verschilien tussen de vier groepen huisartsen te constateren. Dit geldt niet voor de beantwoording van de vragen van de somvariabelen 3 en 4 .

Eveneeens is getoetst of de gemiddelden van de variabelen $3,4,7$ en 8 van de afzonderlijke drie groepen huisartsen van het Diagnostisch Centrum, verschilden van de gemiddelden van deze variabelen van de referentiegroep van huisartsen. Hiervoor gebruikten we wederom de Mann-Whitney toets (zie tabel 6.8.). 


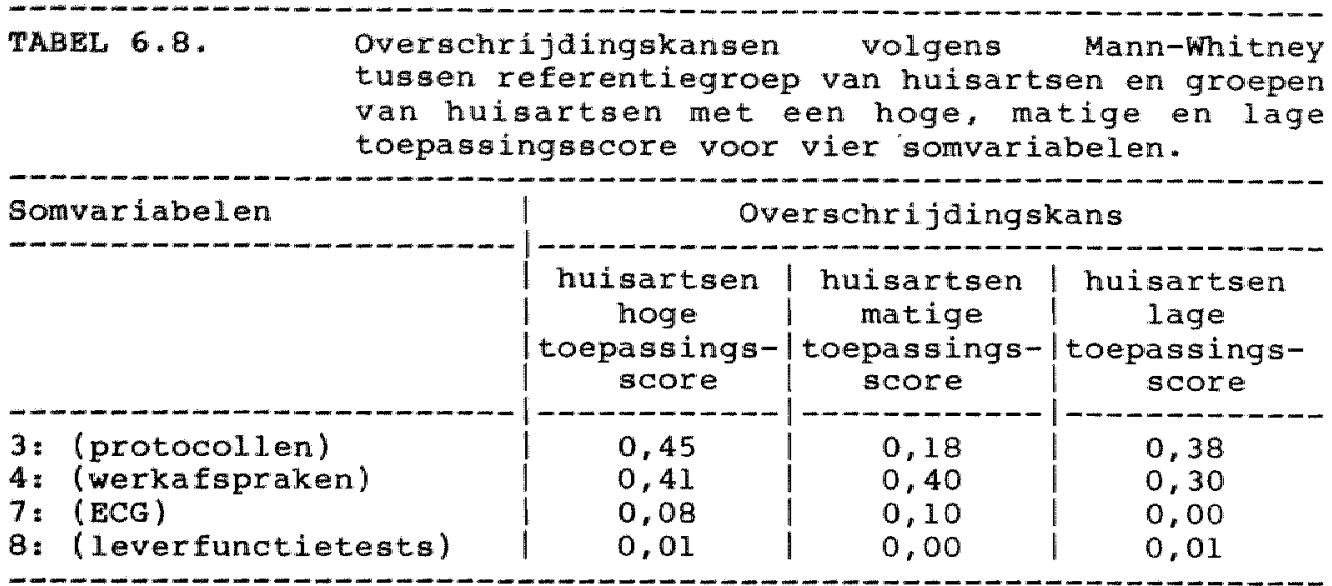

Uit deze toetsen komt naar voren, dat tussen de referentiegroep van huisartsen en de drie groepen huisartsen van het Diagnostisch Centrum, weinig verschillen zijn te constateren met betrekking tot de appreciatie van protocollen en werkafspraken in het algemeen (variabelen 3 en 4 ). Wel zijn significante verschillen warneembar ( op 10\% niveau) voor de variabelen 7 en 8 . Hierop wordt in de volgende paragraaf ingegaan.

\section{- Exploratie van de verschillen.}

Waarin verschillen de met het Diagnostisch Centrum samenwerkende huisartsen van de referentiegroep van huisartsen met betrekking tot de comvariabelen 7 en 8 ? Nadere exploratie van de enquêtegegevens brengt het navolgende naar voren.

De huisartsen van het Diagnostisch Centrum en de referentiegroep van huisartsen hebben in vrijwel gelijke mate behoefte aan een werkafspraak voor ECG-aanvragen. Het al dan niet gewenst vinden van een werkafspraak woor leverfunctietests toont evenwel grote verschilien. Bijna $90 \%$ van de huisartsen van het Diagnostisch Centrum vindt deze werkafspraak gewenst tegenover ruim $50 \%$ van de huisartsen van de referentiegroep.

Het niet gewenst zijn van de werkafspraak voor leverfunctietests wordt door de betreffende 12 huisartsen uit de referentiegroep van huisartsen toegelicht. 
Hierin wordt met name aangegeven, dat door werkafspraken op dit gebied inperking van de diagnostische mogelijkheden voor de huisarts kan plaatsvinden. Werken met een werkafspraak op dit onderzoekgebied kan eveneens het gevar inhouden, dat de eigen verantwoordelijkheid en autonomie van handelen van de huisarts wordt aangetast; duidelijk wordt door meerdere huisartsen uit de referentiegroep het risico van overheersing door de specialist tot uitarukking gebracht.

In de enquete wordt vervolgens ingegaan op de onderzoeksindicaties voor beide werkafspaken.

Allereerst de werkafspraak voor aanvragen ECG. De verschilien tussen de huisartsengroepen zijn niet groot en bedragen slechts bij twee onderzoeksindicaties meer dan 15\%. Dit geldt bij de vraag naar eventueel elimineren van de onderzoeksindicati.e voor aanvragen ECG bij: "vastgesteld geruis aan het hart look bij het kind): boezem- en/of kamerhypertrofie? Geleidingstoornis?"

Slechts $10 \%$ van de Diagnostisch Centrum huisartsen antwoorden hierop bevestigend tegenover ruim 30 o van de huisartsen uit de referentiegroep. In het merendeel van de toelichtingen door de huisartsen uit de referentiegroep wordt angegeven, dat een souffle bij een kind toch steeds verder specialistisch onderzoek vergt. Hier is derhalve sprake van een andere interpretatie van dit onderdeel van de werkafspraak door de huisartsen uit de referentiegroep ten gevolge van onduidelijke formulering in de werkafspraak. Deze onderzoeksindicatie betreft namelijk in hoofdzak het beleid bij een souffle aan het hart bij volwasenen (door geen van de huisartsen van het Diagnostisch centrum wordt de souffle bij het kind als tegenargument naar voren gebracht). Eveneens is het verschil meer dan $15 \%$ voor de EcG-aanvraag indjcatie: "ECG bij hypertensie: effect op het hart? Controle effect therapie". Bijna $30 \%$ van de huisartsen uit de referentiegroep stelt voor deze werkafspraak te schrappen tegenover slechts $10 \%$ van de huisartsen van het Diagnostisch Centrum. Door de hujsartsen wit de referentiegroep worden een aantal situaties naar voren gebracht, warbij volgens hen de betekenjs van een ECG bjj deze 
undicatie van geringe warde is. Daartegenover stat, dat in enkele toelichtingen van andere hulisartsen uit de referentiegroep deze indicatie juist als uiterst wardevol wordt onderschreven. ook bij de laatste vraag of de huisartsen nog andere indicaties voor ECG-aanvragen willen toevoegen is er weinig verschil: ongeveer 12 van de huisartsen van het Diagnostisch Centrum antwoordt hierop bevestigend, tegenover bijna $20 \%$ van de huisartsen uit de referentiegroep. De in de toelichting naar voren gebrachte indicaties zijn vrijwel gelijkluidend.

Samenvattend kon vastgesteld worden dat de exploratie van de verschillen tussen de huisartsen die samenwerken met het Diagnostisch centrum en de huisartsen uit de referentiegroep bij de beantwoording van deel IV A van de enquête toont dat deze verschillen enerzijds voor een groot deel verklaard kunnen worden uit een andere interpretatie van één onderzoekindicatie voor ECG-aanvragen (souffle), anderzijds door een niet in gelijke mate onderschreven behoefte aan een andere onderzoeksindicatie (ECG bij hypertensie-controle).

Op grond van de geconstateerde verschillen in gewenstheid van een werkafspraak voor leverfunctietests, waren ook grotere verschillen te verwachten bij de beoordeling van de diverse onderdelen van de werkafspraak voor leverfunctietesten.

Indien we hetzelfde criterium (meer dan $15 \%$ verschil bij de beantwoording) hanteren $z i j n$ er inderdaad op bijna alle onderdelen van de werkafspraak voor leverfunctletests dergelijke verschilen. De enige uitzondering geldt voor het onderdeel van de gewenstheid van een werkafspraak voor leverfunctietests (alkalische fosfatase, GTP en SGPT) bij patiënten met vage en algemene klachten .

De verschilien bij de overige onderdelen varieren van 20 tot $40 \%$. Vrijwel alle opmerkingen betreffen de wens on onderdelen van de werkafspraak te veranderen dan wel om bepalde leverfunctietests weg te laten (bv. Y-GTP, omdat deze test nogal duur is) of andere leverfunctietests toe te voegen (bv. LHD, bilirubine, enz.). 
Grote verschillen worden eveneens geconstateerd in de door de huisartsen aangegeven wenselijkheid on onderdelen aan de werkafspraak voor leverfunctietests toe te voegen. Deze wenselijkheid wordt door bijna $30 \%$ van de huisartsen van de referentiegroep onderschreven, tegenover slechts door 5 f van de huisartsen die samenwerken met het Diagnostisch Centrum.

Meer uitgebreide concrete toelichting van bovengenoemde geconstateerde verschillen ten aanzien van de wenselijkheid om te veranderen, alsmede ten aanzien van de wenselijkheid om onderdelen toe te voegen, zou in deze context te ver voeren. De geconstateerde verschillen werden aan drie specialisten op het gebied van leverfunctietests, waarvan twee niet verbonden an het Diagnostisch Centrum, ter beoordeling voorgelegd.

Hun conclusie was eensluidend: de door de huisartsen van de referentiegroep naar voren gebrachte opmerkingen zijn voor het overgrote deel inadequat. Het mag dan ook waarschijnlijk geacht worden, dat van de invoering en toepasssing van de werkafspraak voor leverfunctietests een zodanig leereffect is uitgegaan dat op grond hiervan de verschilien verklaard zouden kunnen worden. In dit verband dient vermeld te worden, dat vanuit het Diagnostisch Centrum tegelijk met de invoering van de werkafspraak in het Informatiebulletin uitgebreide toelichting verschaft werd over de problematiek op het gebied van deze werkafspraak.

6. 4. DE ANALYSE EN DE SAMENHANGEN VAN DE INTERVIEWGEGEVENS MET DE TOEPASSING VAN DE WERKAFSPRAKEN.

Het belangrijkste doel van de interviews was te exploreren, warom de huisartsen bij concreet aangegeven aanvragen voor diagnostisch onderzoek de werkafspraken niet hadden toegepast.

Het was niet zeker, dat met de interviews de drie groepen van huisartsen ten opzichte van elkaar te onderscheiden zouden zijn. Door ons werd verondersteld dat, indien er verschilien te constateren zouden zijn, deze dan toch in de eerste plats zouden bestaan tussen die groepen huisartsen, die het meest van elkaar verschilden in de toepassing van de werkafspraken, nameljjk de 
huisartsen met eer hoge toepassingsscore en de huisartsen met een lage toepassingsscore.

Wij hebben darom alleen de interviews van huisartsen met een hoge en huisartsen met een lage toepassingscore geanalyseerd op samenhangen tussen de scores en interviewgegevens. Zoals eerder onder meetresultaten vermeld, werden 47 van de 56 hujsartsen die de enquête hebber ingevuld, geinterviewd. Hieronder 12 van de 13 hulisartsen met een hoge toepassingsscore en 13 van de 15 huisartsen met een lage toepassingsscore.

- DE REDENEN OM IN CONCRETE SITUATIES DE WERKAFSPRAKEN NTET TOE TE PASSEN

Door liedere huisarts werden een aantal redenen naar voren gebracht om in concrete situaties de werkafspraken niet toe te passen (zie bijlage IV).

Het a antal nat voren gebrachte redenen verschilde per huisarts, enerzijds doordat aan iedere huisarts een variërend aantal (drietot vifftal) anvraagformulieren werd getoond, warin hij de werkafspraak niet had toegepast, anderzijds omdat er door de huisartsen bij.j sommige anvragen meerdere redenen werden genoemd om in deze concrete situatie de werkafspraak niet toe te passen.

Door ons werd geanalyseerd of het mogelijk was de twee groepen huisartsen successievelijk de huisartsen met een hoge toepasgingsscore en de huisartsen met een lage toepassingsscore, ten opzichte van elkaar te onderscheiden. Daartoe werden de naar voren gebrachte redenen gecategoriseerd in een vijftal groepen:

- redenen betreffende het Diagnostisch Centrum

- redenen betrefende het medisch handelen

- patiëntgebonden redenen

- artsgebonden factoren

- redenen "derden" betreffende.

In tabel 6.10. worden de door de huisartsen met een hoge en de huisartsen met een lage toepassingsscore naar voren gebrachte redenen schematisch weergegeven. 
TABEL 6.10 .

In interview bij twee groepen huisartsen naar voren gebrachte redenen om werkafspraken bij concrete onderzoeksaanvragen niet toe te passen.

Redenen

Redenen betr. het Diagnostisch Centrum

onbekendheid met werkafspraken

- ontbreken feedback

- teveel werkafspraken

- ontbreken werkafspraken "check-up"

Redenen betr. het medisch handelen

- multiple pathologie

- patiënt die je niet vaak ziet

- vage klachten

- ernstige pathologie

- bepalde ziektebeelden

- controle

Patiëntgebonden redenen

- đruk patiënt

- privacy patient

- geruststelling patiënt

Artsgebonden redenen

- werkafspraak slechts rïchtlijn

- vergeten

- slordig

- routine

- tijasdruk

Redenen "derden" betreffend

- druk van builtenaf

- werkafspraak met anderen

huisartsen | huisartsen met hoge I met lage toep.score | toep.score toep. score $\mid$ toep.
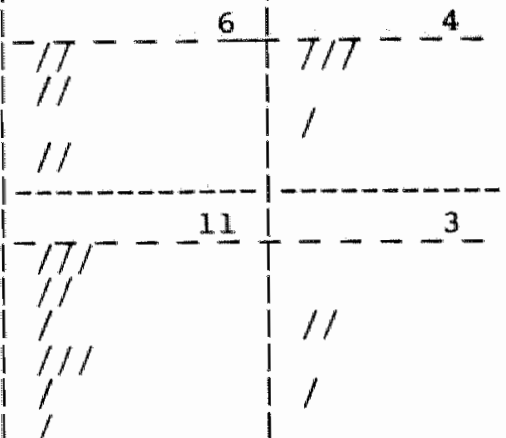

Door de huisartsen met een hoge toepassingsscore werd elf mal als argument voor hun niet toepassen van de werkafspraken, redenen vanuit het medisch handelen genoemd, tegenover slechts drie mal door de huisartsen met een lage toepassingsscore. Artsgebonden redenen darentegen werden vaker door de huisartsen met een lage toepassingsscore naar voren gebracht (22), dan door de huisarten uit de hoge toepassingsscoregroep (16).

De analyse laat geen andere samenhangen zien tussen de twee groepen van huisartsen. 


\section{- DE WRRKAPSPRAKEN IN HET ALGEMERN}

B1jna alle geinterviewde hutsartsen ervaren de werkafspraken als positief. Door een aantal huisartsen werd beklemtoond, dat het inderdaad noodzakelijk is om met werkafspraken te werk te gaan. In de aanvullende opmerkingen gaven vijf huisartsen met een lage toepasingsscore aan, de werkafspraken slechts als een richtlijn te willen zien. Een aantal huisartsen met een hoge toepassingsscore gaf aan, dat ze de werkafspraken nog vaak opnleuw bekijken om ze op die manier te kunnen onthouden. Bij dit onderdeel van het interview konden geen duidelijke samenhangen aangetoond worden bij de twee groepen van huisartsen.

\section{- DE INVULLING VAN DE AANVRAAGFORMULIEREN}

Met betrekking tot de invulling van de anvraagformulieren lieten de huisartsen een $v \mathbb{1} i j$ uniform antwoordpatroon te zien. Vrijwel alle huisartsen gaven aan, het nu gehanteerde aanvraagformulier wel bruikbaar te vinden. Andere informatie hieromtrent werd spontaan niet naar voren gebracht.

\section{- DE GEGEVEN OF GEWENSTE FEEDBACK}

De feedback werd door vrijwel alle hujsartsen als redelijk positief ervaren. De hulsartsen met een lage toepassingsscore gaven vaker aan behoefte te hebben aan meer gerichte feedback (niet alleen procentuele getallen). Ook bij dit onderdeel van het interview werden door ons geen duidelijke samenhangen geconstateerd.

\section{- PLAATS EN FUNCTIE VAN HET DIAGNOSTISCH CENTRUM}

Het Diagnostisch Centrum werd vrijwel zonder uitzondering door alle huisartsen als uiterst positief ervaren. Wel werd menigmaal betreurd, dat er sedert enige tijd minder nieuwe initiatieven genomen worden. 


\section{Samenvatting:}

Uit de interviewgegevens kwamen slechts enkele factoren naar voren, welke discrimineerden tussen de groep huisartsen met een hoge toepassingsscore en de groep huisartsen met een lage toepassingsscore.

Bij de vergelijking van beide groepen geven de huisartsen met een hoge toepassingsscore vaker redenen vanuit het medisch handelen aan als argument voor hun niet toepassen van de werkafspraken. De huisartsen met een lage toepasingsscore brengen als zodanig vaker artsgebonden redenen naar voren. Ook brengen zij naar voren meer behoefte te hebben aan meer gerichte feedback.

\subsection{DE ANALYSE EN DE SAMENHANGEN VAN DE ALGEMENE GEGEVENS OVER DE HUISARTSEN EN HUN PRAKTIJK MET DE TOEPASSING VAN DE WERK-} AFSPRAKEN.

Voor de bepaling van de toepassingsscore zijn 44 huisartsen geselecteerd. Bij de analyses van bovengenoemde samenhangen zijn, met uitzondering van de relatie met de urbanisatiegraad van de praktijk, slechts 43 huisartsen betrokken. Eén huisarts met een lage toepassingsscore was eerst zeer recent vrij gevestigd en zijn praktijk telde op het moment van het onderzoek minder dan 100 ziekenfondspatiënten. Aangezien dit uiterst lage getal de overige analyses te sterk zou beinvloeden werd door ons besloten de gegevens van deze huisarts te elimineren. Ondat $h i j / z i j$ anderzijds genoeg onderzoeksaanvragen had gedaan was er geen reden deze huisarts aok bij de vorige analyses te elimineren. Onderstaand zullen we achtereenvolgens de samenhangen voor de navolgende algemene variabelen analyseren:

- kenmerken van de praktijk

- grootte van de praktijk

- urbanisatiegraad van de praktijk

- kenmerken van de huisarts (absolute getallen en getallen gecorrigeerd naar praktijkgrootte)

- totale hoeveelheid aanvragen voor diagnostisch onderzoek bij het Diagnostisch Centrum 
- hoeveelheid aanvragen voor ECG bij het Diagnostisch Centrum

- hoeveelheid anvragen voor leverfunctietests bij het Diagnostisch Centrum

- totale hoeveelheid verwijzingen naar de specialist

* hoeveelheid verwijzingen naar cardioloog

- hoeveelheld verwijzingen naar internist.

6.5.1. Kenmerken van de praktijk.

6.5 .1 .1 . Grootte van de praktijk.

De grootte van de ziekenfondspraktijk van de huisartsen is bij het Diagnostisch Centrum bekend. Als richtlijn voor de berekening van de totale praktijkpopulatie vanuit deze ziekenfondsgegevens wordt in het algemeen gesteld, dat gemiddeld $70 \%$ van de huisartspraktijk uit ziekenfondspatiënten bestaat. Er waren geen redenen om in dit onderzoek van deze berekeningsrichtlijn voor de praktijkpopulaties af te wijken. De totale praktijkgrootte, berekend op deze wijze vanuit het antal ziekenfondsverzekerden, van de groepen hujiartsen met een hoge en een lage toepassingsscore wordt weergegeven in tabel 6.11.

TABEL 6,11 .

Gemiddelde grootte van de huisartspraktijk voor twee groepen van de huisartsen.

\begin{tabular}{l|l|l|} 
groepen hulsartsen & $\begin{array}{l}\text { gemiddelde } \\
\text { huktijk grootte }\end{array}$ \\
\hline huisartsen met hoge toepassingsscore & circa 2375 \\
\hline
\end{tabular}

Huisaxtsen met een hoge toepasingsscore bleken een circa 108 kleinere praktijk te hebben dan de huisartsen met een lage toepassingsscore. Er kan geconstateerd worden, dat de praktijkgrootte van de huisartsen met een hoge toepassingsscore goed overeenkomt met heden ten dage door LHV en overheid nagestreefde normpraktijkgrootte van 2350 patienten. 
6.5.1.2. Urbanisatiegraad praktijk.

Huisartsen van Mastricht en omgeving maken gebruik van het Diagnostisch Centrum. In figuux 1.I. wordt getoond, hoe de situering is van de huisartspraktijken over Maastricht en de regio buiten Mastricht. Mastricht is een stad van circa 110.000 inwoners. In de regio Maastricht zijn de praktijken van de overige met het Diagnostisch Centrum samenwerkende huisartsen alle gesitueerd in met elkaar qua grootte vergelijkbare kleine plaatsen. Bij het bepalen van de urbanisatiegraad van de praktijken werd door ons op grond van bovengenoemde situering een tweedeling gehanteerd:

- praktijken gelocaliseerd in Mastricht:

- praktijken gelocaliseerd in de plaatsen rondom Maastri.cht. Met andere woorden: praktijken met hoge urbanisatiegraad zijn praktijken gesitueerd in Mastricht en praktijken met lage urbanisatiegraad zijn praktijken gesitueerd in de plaasten rondom Mastricht.

De verdeling van de huisartspraktijken op grond van dit urbanisatiegraadcriterium wordt in tabel 6.12. getoond.

TABEL 6.12 *

Urbanisatiegraad van huisartspraktijken voor 2 groepen wan de huisartsen. (\%)

\begin{tabular}{l|l|l|l|}
\hline Groepen huisartsen & Maastricht & ongeving \\
\hline huisartsen met hoge toepassingsscore & 85 & 15 \\
\hline huisartsen met lage toepassingsscore & 60 & 40
\end{tabular}

De praktijken van de groep hujsartsen met een hoge toepassingsscore vertonen een beduidend hogere urbanisatiegraad dan de praktijken van de groep huisartsen met een lage toepassingsscore. wanneer we de huisartspraktijken indelen wat urbanisatiegraad betreft en vervolgens de toepassingsscore van alle praktijken analyseren, komt naar voren, dat van de hulisartsen, warvan de praktijk een lage urbanisatiegraad bezit, $60 \%$ een lage toepas 
singsscore heeft, terwijl in vergelijking daarmee van de huisartsen met een praktijk met een hoge urbanisatiegraad, slechts $26 \%$ een lage toepassingsscore heeft. Zie tabel 6.13.

TABEL 6.13 .

Urbanisatiegraad huisartspraktijken en toepassingsscore voor twee groepen van de huisartsen. (8)

hoge urbanisatiegraad $\mid$\begin{tabular}{|c|} 
hoge score | matige score \\
\hline lage urbanisatiegraad
\end{tabular}

De conclusie is, dat huisartsen met een praktijk met een lage urbanisatiegraad gemiddeld de werkafspraken beduidend vaker niet toepassen dan huisartsen met een praktijk met eer hoge urbanisati.egraad.

6.5.2. Kenmerken van de huisarts.

6.5 .2 .1 . Hoeveelheid aanvragen voor diagnostische onderzoeken bij het Diagnostisch Centrum.

Bij het Diagnostisch Centrum kunnen voor diverse diagnostische onderzoeken aanvragen gedaan worden. op het aanvraagformulier (zie bijlage I) worden onderscheiden:

- chemisch bloedonderzoek, haematologie, serologie;

- bacteriologie, faeces onderzoek, urine onderzoek;

- radiodiagnostiek, echografie, endascopie;

- electrocardiografie;

- histologie/cytologie.

Het gemiddelde aantal door de huisartsen aangevraagde diagnostische onderzoeken werd door ons bepaald over een periode van twalf maanden. Deze aanvragenhoeveelheid wordt in tabel 6.14. weergegeven voor de groepen huisartsen met een hoge en met een lage toepassingsscore. In kolom 1 de absolute aantallen en in kollom 2 deze getallen gecorrigeerd voor praktijkgrootte. 
TABEL 6.14 .

Hoeveelheid aanvragen voor diagnostisch onderzoek bij het Diagnostisch Centrum voor twee groepen huisartsen (periode van 12 maanden).

groepen huisartsen

hoeveelheid aanwragen

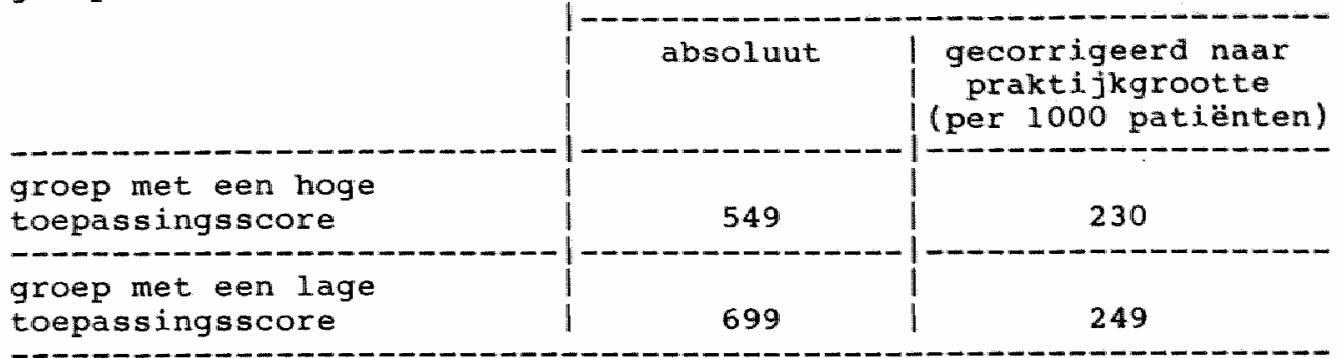

Deze analyse laat zien dat de huisartsen met een lage toepassingsiscore, wat alle diagnostische onderzoeken betreft, gemiddeld circa $8 \%$ meer onderzoeken aanvragen bij het Diagnostisch Centrum dan de huisartsen met een hoge toepassingsscore.

Voor de ECG-aanvragen worden deze hoeveelheden onderzoekaanvragen weergegeven in tabel 6.15. Ook hier is in kolom 2 de correctie naar praktijkgrootte toegepast.

TABEI 6.15 .

Hoeveelheid aanvragen voor ECG voor twee groepen huisartsen (periode van 12 maanden).

groepen huisartsen

aanvragen ECG

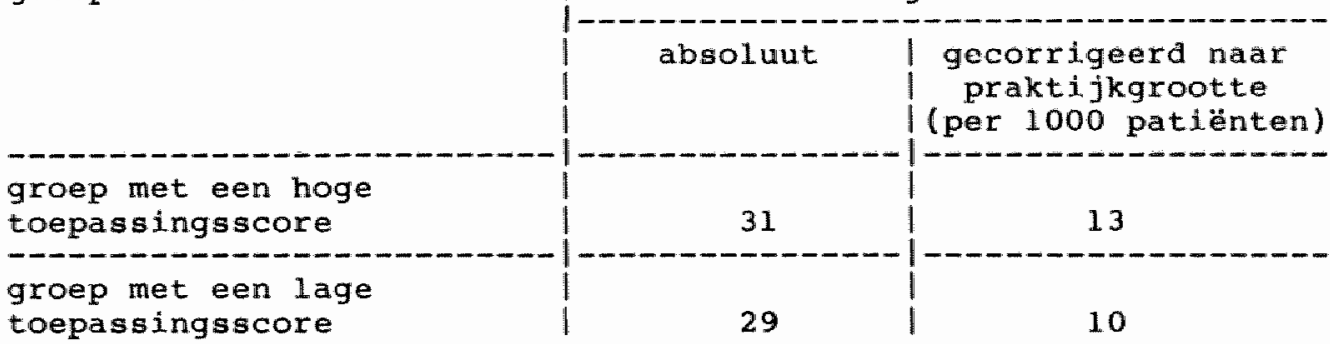

Blj de analyse van de hoeveelheid onderzoekaanvragen voor EcGaanvragen is er een duidelijk lager (circa 25\%) gebruik door de groep huisartsen met een lage toepassingsscore. 
Voor de aanviagen voor leverfunctietests zijn deze aantallen zichtbaar in tabel 6.16. Het betreft alle aanvraagformulieren warop één of meer leverfunctietests werden aangevraagd. Als "Leverfunctietests" worden beschouwd: alkalisch fosfatase,y-GTP, SGOT, SGPT, LDH, bilirubine totaal, bilirubine direct en Paul Bunel1 (Monosticon).

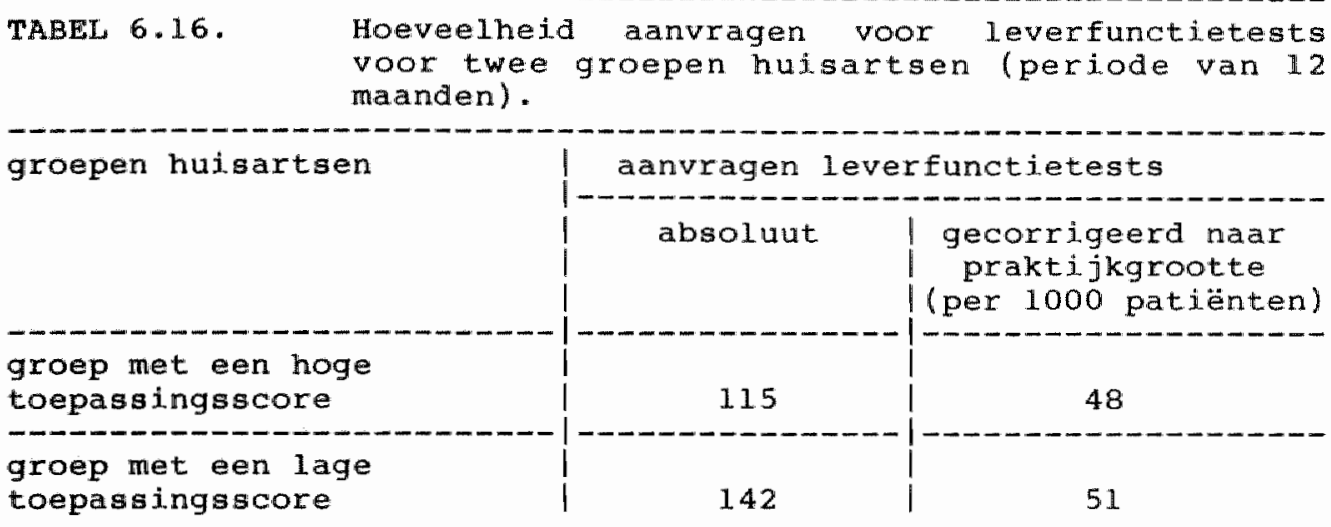

Bij de analyse van de hoeveelheid onderzoekaanvragen voor leverfunctietests is er voor de huisartsen met een lage toepassingsscore een licht verhoogd (circa 68) gebruik.

6.5.2.2. Hoeveelheid verwijzingen naar de specialist.

De hoeveelheid verwijzingen voor ziekenfondspatiënten zijn op jaarbasis berekend per 1000 ziekenfondspatiënten. De totale hoeveelheid verwijzingen betreft verwijzingen naar alle specialismen.

Het gemiddelde totale verwijscijfer op jaarbasis voor de groepen huigartsen met een hoge en een lage toepassingsscore wordt weergegeven in tabel 6.17. In kolom 1 zijn de absolute aantallen weergegeven en in kolom 2 deze getallen gecorrigeerd naar praktijkgrootte. 
TABEL, 6.17

Totaal a antal verwijzingen op jaarbasis voor twee groepen huisartsen.

groepen huisartsen

hoeveelheid verwitgingen

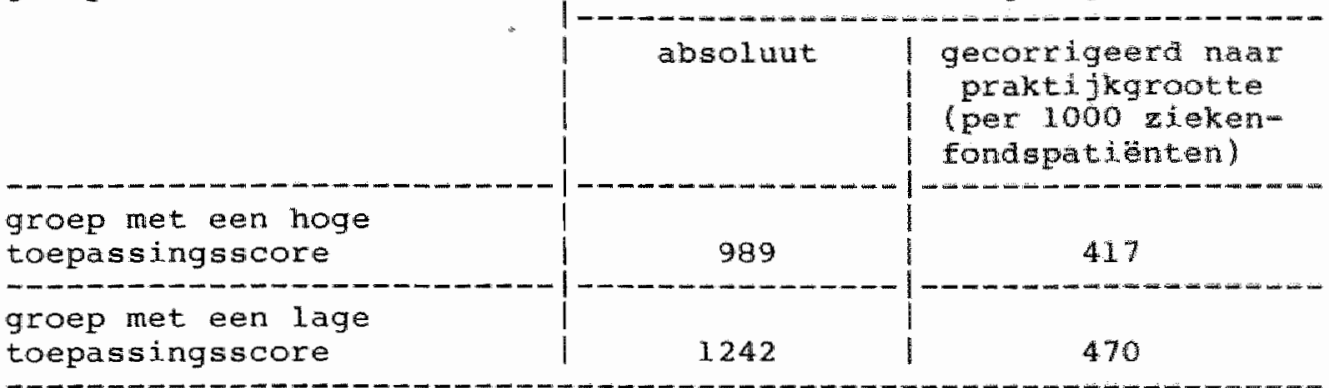

De huisartsen uit de groep met een lage toepassingsscore verwijzen gemiddeld ruim $11 \%$ meer (gecorrigeerd naar praktijkgrootte) dan de huisartsen met een hoge toepassingsscore.

Ondat in het onderzoek de werkafspraken voor ECG en voor leverfunctietests nader werden bezien, is vervolgens door ons het verwijscijfer geanalyseerd naar de afdeling cardiologie en naar de afdeling interne geneeskunde.

De verwijscijfers naar de afdeling cardiologie worden weergegeven in tabel 6.18 .

TABEL 6.18 .

Aantal verwijzingen naar afdeling cardiologie voor twee groepen hus sartsen.

\begin{tabular}{|c|c|c|}
\hline groepen huisartsen & $\mid \begin{array}{r}\text { verwijzinger } \\
\text { absoluut }\end{array}$ & $\begin{array}{l}\text { cardiologie } \\
\text { gecorrigeerd naar } \\
\text { praktijkgrootte } \\
\text { (per } 1000 \text { zieken } \\
\text { fonds patidenten) }\end{array}$ \\
\hline groep met een hoge & & \\
\hline toepassingsscore & 70 & 29 \\
\hline $\begin{array}{l}\text { groep met een lage } \\
\text { toepassingsscore }\end{array}$ & 80 & 30 \\
\hline
\end{tabular}

Bij de analyse van het aantal verwijzingen naar de afdeling cardiologie blijkt vrijwel geen verschil tussen de groep huisartsen met een hoge en een lage toepassingsscore. 
De verwijscijfers nat de afdeling interne geneeskunde zijn zichtbaar in tabel 6.19 .

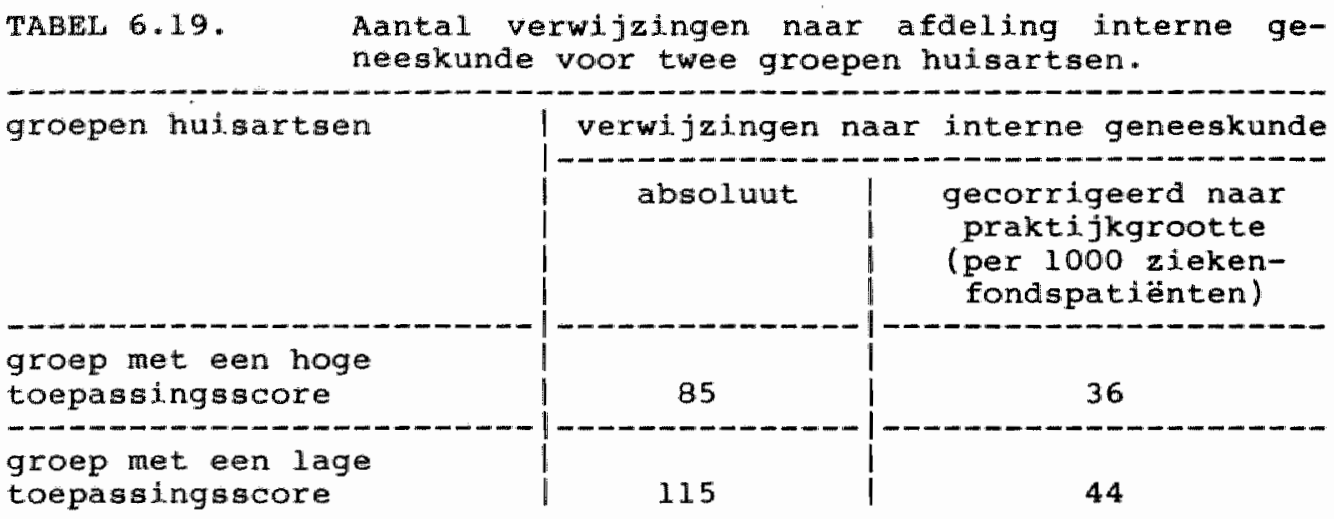

Uit de analyse van de verwijzingen naar de afdeling interne geneeskunde komt nar voren, dat de huisartsen met een lage toepassingsscore circa $22 \%$ meer verwijzen naar de internist dan de huisartsen met een hoge toepassingsscore.

Samenvattend hebben de huisartsen met een hoge toepassirgsscore een beduidend lager totaal verwijscijfer naar de specialist dan de huisartsen met een lage toepassingsscore. Bij de verdere analyse van de verwijzingen naar de afdeling cardiologie en de afdeling interne geneeskunde wordt dit verschil eveneens geconstateerd voor de verwijzingen nar de afdeling interne geneeskunde, mar niet voor het aantal verwijzingen naar de afdeling cardiologie. 
7. DE INDIVIDUELE EEEDBACK AAN DE HUISARTSEN OVER DE TOEPASSING VAN DE WERKAFSPRAKEN.

\subsection{INLEIDING.}

In de paragraaf over de onderzoeksopzet is uiteengezet, dat het idee van het geven van individuele feedback, zoals gepland in de allereerste onderzoeksopzet, door de beleidsgroep van het E.D.C.M. als uiterst wardevol werd beoordeeld en dat in het kader van de evaluatie van het E.D.C.M. het geven van deze individuele feedback werd geanalyseerd.

Door middel van de geoperationaliseerde mogelijkheid om de toepassing van werkafspraken per huisarts te beoordelen kon aan de huisartsen individuele feedback worden gegeven over hun toepassing van de werkafspraken.

De individuele feedback had betrekking op de toepassing van een drietal werkafspraken:

- aanvragen ECG;

- aanvragen leverfunctietests:

- aanvragen röntgenonderzoek lumbosacrale wervelkolom.

De feedback betrof het nakomen van de in de werkafspraak aangegeven onderzoeksindicaties voor wat betreft aanvragen ECG en aanvragen röntgenonderzoek lumbosacrale wervelkolom en de aangegeven onderzoeksbepalingen in relatie tot klinische beelden voor de aanvragen van leverfunctietests.

De feedback gaf aan in welk percentage de aanvragen voor elk van deze drie onderzoekcategorieën niet in overeensteming waren met de in de werkafspraak genoemde onderzoeksindicaties/onderzoeksbepalingen (zie schema 7.1.$)$. 
SCHEMA 7.1 .

Feedback formulier, algemene individuele feedback

Persoonlijke feedback E.D.C. van de mand ........... 1982/1983

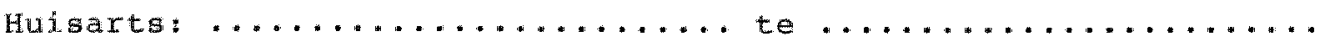
Aantal aanvragen: Rö-X-1umbosacrale wervelkolom ...........

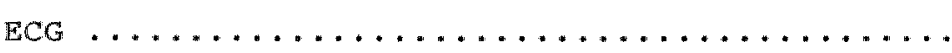

Leverfunctie-onderzoek .................

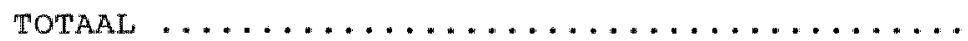

Aantal onderzoeks-aanvragen niet in overeenstemuing met werkafspraken: $\ldots \ldots \ldots \ldots \ldots . \ldots \ldots \ldots$. $\ldots \ldots \ldots$

coördinator E.D.C.

De feedback is gegeven over de onderzoeksaanvragen van de huisartsen over een periode van telkens één maand. Op deze wijze is gedurende vier opeenvolgende maanden aan de huisartsen individuele feedback verstrekt.

Het geven van de feedback is in het Informatiebulletin van het Diagnostisch centrum aangekondigd en nogmaals in een brief van de coördinator van het Diagnostisch centrum toegelicht.

Uit de ontvangen reacties van de huisartsen op de individuele feedback over de eerste mand kwam naar voren, dat meer gerichte feedback, met name ten aanzien van de aanvragen voor leverfunctietests, door de huisartsen op prijs zou worden gesteld. Op dit verzoek is ingegaan en over de resterende drie maanden is voor de werkafspraak voor röntgenonderzoek van de lumbosacralewervelkolom en de werkafspraak voor anvragen ECG algemene individuele feedback en voor de werkafspraak voor aanvragen van leverfunctietests meer gerichte individuele feedback gegeven (zie schema 7.2.). 
SCHEMA 7.2. Feedback formulier voor meer gerichte individuele feedback ten aamien van de werkafspraak voor leverfunctietests.

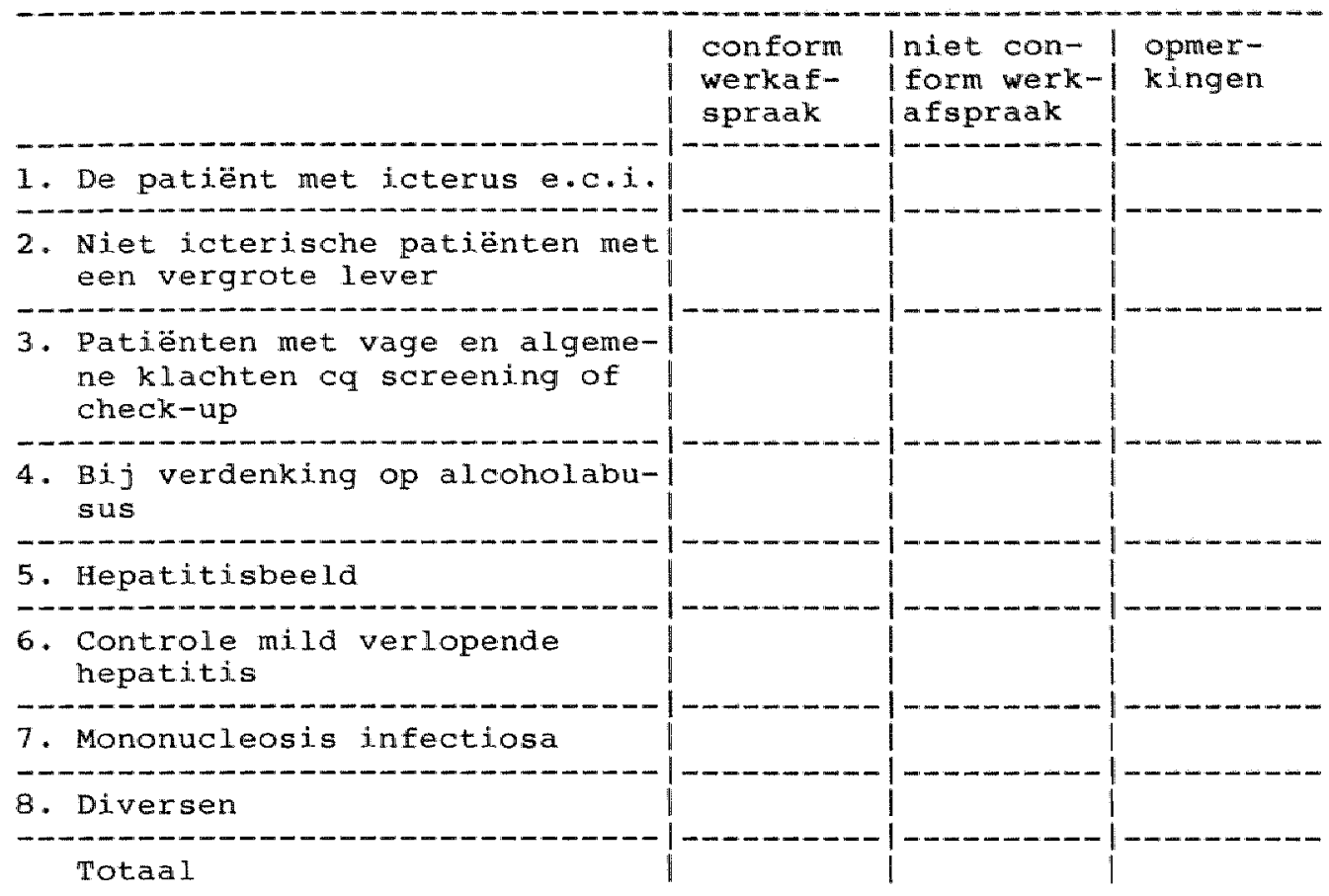

\section{2. MEETRESULTATEN}

De individuele feedback is aan de huisartsen verstrekt over de manden oktober, november, december 1982 en januar 1983 . In tabel 7.1. zijn de scores van de huisartsen weergegeven. Deze scores geven aan de percentages, warin de huisartsen de werkafspraken toepasten. 
TABEL 7.1 .

Hi.stogram van huisartsen nar hun percentages, toepassing in overeensteming met de werkafspraken, over vier feedback perioden (ieder kruisje staat voor één huisarts).

\begin{tabular}{|c|c|c|c|c|c|}
\hline & & OKTOBER 82 & NOVEMBER 82 & DECEMBER 82 & JANUARI 83 \\
\hline 0 & $-5 z$ & $x \times x \times x$ & $x$ & $\mathrm{x}$ & $\mathrm{x}$ \\
\hline 5 & $-10 \%$ & $x \times x$ & $x \times x$ & $x$ & \\
\hline 10 & -158 & $x \times$ & $\mathrm{x}$ & 1 & $x \times x$ \\
\hline 15 & -208 & $x \times x \times x$ & $x \times x$ & $x \times$ & $\mathrm{xx}$ \\
\hline 20 & $-25 \%$ & $x \times \times \times \times x$ & $\mathrm{x}$ & $x \times x \times$ & $\mathrm{x}$ \\
\hline 25 & $-30 z$ & $x x$ & $x \times \times \times \times x$ & 1 & $x x$ \\
\hline 30 & -358 & $x \times \times \times \times x$ & $\times \times \times \times \times x$ & $\mathbf{x} x$ & $x \times \times \times$ \\
\hline 35 & -408 & $x \times \times \times \times \times$ & $\mathrm{x}$ & $\mathrm{x} \times \mathrm{x}$ & $\mathrm{xx}$ \\
\hline 40 & $-45 \%$ & $\mathrm{x} \times \mathrm{x}$ & $\mathrm{xx}$ & $x x$ & $x \times x$ \\
\hline 45 & $-50 \%$ & $x \times x$ & $\mathrm{xxx}$ & $\times \times \times \times \times$ & $x \times$ \\
\hline 50 & -55 & & $\mathrm{xxxx}$ & $\times \times \times \times \times \times \times x$ & $x \times$ \\
\hline 55 & -608 & $x \times$ & $x \times x \times$ & $\mathrm{x}$ & $x \times x$ \\
\hline 60 & -65 & $x$ & $x$ & 1 & $\mathrm{xxx}$ \\
\hline 65 & $-70 \%$ & $\mathrm{x}$ & 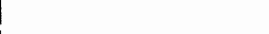 & $\mathrm{x}$ & $x \times x \times$ \\
\hline 70 & -758 & $\mathrm{x}$ & $\mathrm{xx}$ & $\mathrm{xx}$ & $\mathrm{x} \times \mathrm{x}$ \\
\hline 75 & -808 & $\mathrm{x} \times \times \times$ & $\mathrm{x}$ & $x \times x \times$ & $x \times x \times$ \\
\hline 80 & $-85 \%$ & $\mathrm{xx}$ & $\mathrm{xxx}$ & $x \times x \times x$ & $\times \times \times \times \times$ \\
\hline 85 & -908 & $\mathrm{x}$ & $x \times x$ & $\mathrm{x} \times \mathrm{xx}$ & $x \times x \times x$ \\
\hline 90 & -958 & & $\mathrm{x}$ & $\mathbf{x}$ & \\
\hline 95 & -1008 & $\mathrm{x}$ & $\mathrm{x} \times \mathrm{x}$ & $\times \times \times \times x$ & $x \times x$ \\
\hline tot & cal & 54 & 49 & 50 & 52 \\
\hline
\end{tabular}

Van de huisartsen met vijf of minder aanvragen per maand zijn geen toepassingsscores berekend. Een aantal huisartsen zijn op grond van dit criterium geelimineerd. In tabel 7.2. zijn de gemiddelde scores van de huisartsen per mand weergegeven over de periode oktober $1982 \mathrm{t} / \mathrm{m}$ januari 1983 . 
TABEL 7.2 .

De gemiddelden van de percentages, toepassing in overeensteming met de werkafspraken door de huisartsen, over vier feedback perioden.

\begin{tabular}{|c|c|c|}
\hline feedback periode & $\begin{array}{l}\text { aantal huisartsen } \\
\text { (uitvallers) }\end{array}$ & $\begin{array}{l}\text { gemiddelde percentages } \\
\text { toepassing in overeen- } \\
\text { stemming met de werkaf- } \\
\text { spraken (standaardaf- } \\
\text { afwijking) }\end{array}$ \\
\hline oktober 1982 & (11) & $\begin{array}{r}39,2 \\
(26,1)\end{array}$ \\
\hline november 1982 & $\begin{array}{r}49 \\
(17)\end{array}$ & $\begin{array}{r}50,6 \\
(27,2)\end{array}$ \\
\hline december 1982 & $\begin{array}{r}50 \\
(16)\end{array}$ & $\begin{array}{r}61,3 \\
(27,2)\end{array}$ \\
\hline januari 1983 & $\begin{array}{r}52 \\
(16)\end{array}$ & $\begin{array}{r}60,2 \\
(26,5)\end{array}$ \\
\hline
\end{tabular}

De eerste manden stijgen de gemiddelden van de toepassingspercentages van de huisartsen. De latste maand is hierin een stabiLisatie ingetreden.

Hoe zou de toepassing van de werkafspraken door de huisartsen zijn enige maanden na het beëindigen van de individuele feedback? Zouden de huisartsen, zoals aangegeven in de literatuur (Rhyne et al., 1979; Dombal et al., 1974), wederom tot hun vorige toepassingsgedrag terugkeren? In het kader van het onderzoek is de toepassing van de werkafspraken gemeten over de maanden maat, april en mei 1983. Op deze wijze was het mogelijk de toepassingsscore van de huisartsen enige maanden na het beeindigen van de individuele feedback nogmaals te berekenen. Op grond van het criterium: bij minder dan vijf aanvragen per maand (15 over drie maanden) geen berekening van de toepassingsscore, zijn 17 huisartsen geelimineerd van de 56 huisartsen, door wie de enquête werd ingevuld. De resultaten van de scores van de resterende huisartsen $z i j n$ in tabel 7.3 . weergegeven. 
TABEL 7.3 .

Histogram van huisartsen naar hun percentages toepassing in overeensteming met de werkafspraken over de periode matr, april en mei 1983 en over de periode oktober, november en december 1984 (ieder kruisje staat voor één huisarts)

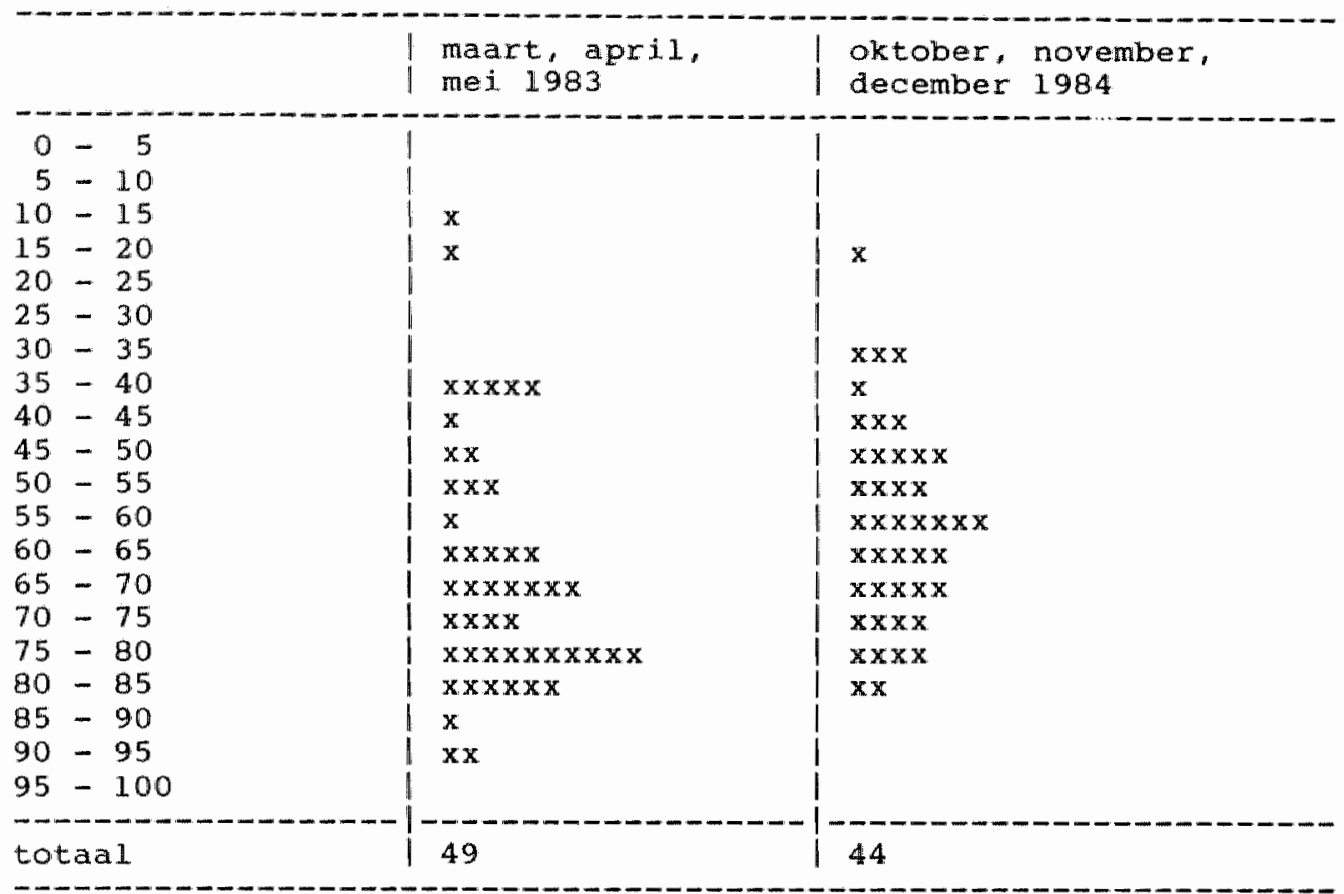

De gemiddelde score toepassing-overeenkomstig-de-werkafspraken over de maanden maart, april en mei 1983 bedroeg $71 \%$. Ten opzichte van de laatstgemeten toepassingsscore over de maand januari 1983 is er een toename van circa 108 opgetreden in de gemiddelde score van de huisartsen, waarin zij de werkafspraken toepassen.

Om te bezien of er inderdaad een bIjjvende verandering in toepassingsgedrag heeft plaatsgevonden, is na een periode van anderhalf jaar, ter follow-up meting, nog een derde meting verricht naar de toepasing van de werkafspraken. Dit geschiedde over de maanden oktober. november en december 1984. Op grond van het eerder gehanteerde criterium, bij minder dan vijftien aanvragen over drie maanden geen berekening van de toepassingsscore, resteerden 44. huisartsen van wie de toepassingspercentages zijn gescoord (zi.e eveneens tabel 7.3. ). 
De gemiddelde score toepassing overeenkomstig de werkafspraken over de perioden oktober $1984 \mathrm{t} / \mathrm{m}$ december 1984 bearoeg 598 en is daarmee vrijwel gelijk aan het over januari 1983, op het eind van de gegeven individuele feedback, geconstateerde gemiddelde toepassingspercentage (zie figuur 7.1. ).

FIGUUR 7.1

De gemiddelde percentages toepassing in overeenstemming met de werkafspraken door de huisartsen over de beoordelingsperioden.

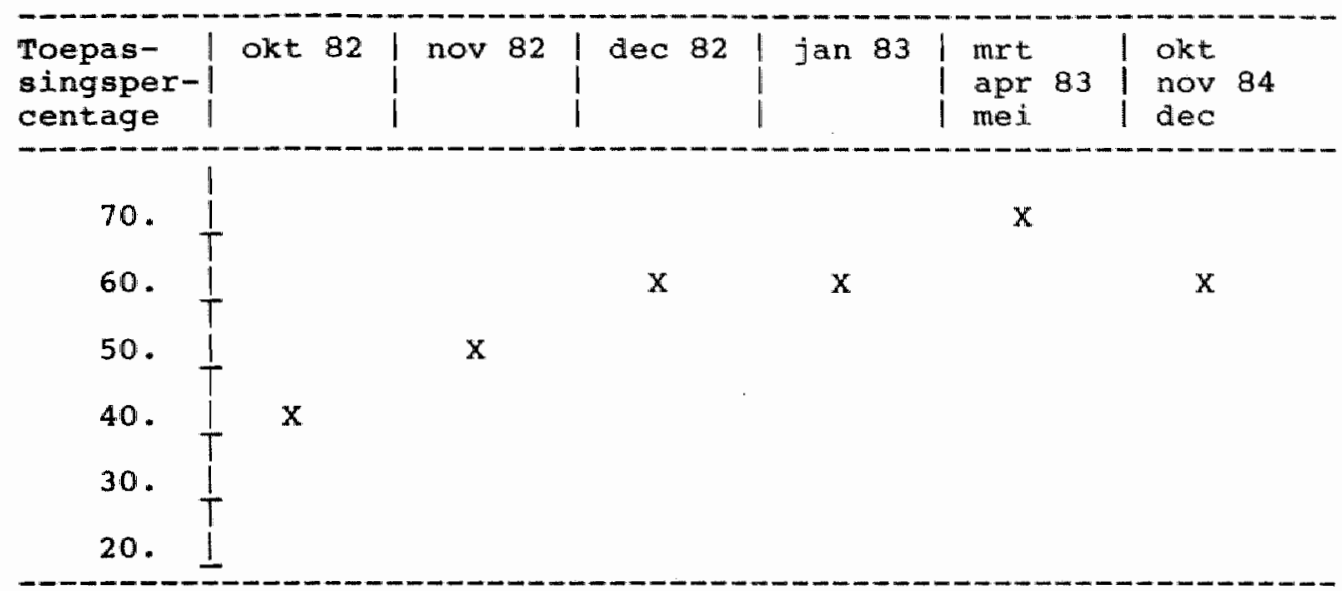

Samenvattend kont uit de analyse van de meetresultaten met betrekking tot de gegeven feedback naar voren:

- In de periode dat de individuele feedback am de huisartsen is gegeven vond er een duidelijke verbetering plaats van de toepassing van de werkafspraken. Het gemiddelde percentage toepassing in overeensteming met een drietal werkafspraken steeg over de periode van vier maanden van circa 40 tot circa 60 \&.

- Het percentage toepassing overeenkomstig de werkafspraken gemeten; een viertal maander na het beëindigen van de feedback, over een periode van dri.e maanden, lat een nog verdere stijging van 10 zien.

- Een meting van het toepassingspercentage circa anderhalf jaar na het beëindigen van de feedback, toont dat het toepassingspercentage nog gelijk is an dat ten tijde van de beeindiging van de individuele feedback. Dit in tegenstelling met de literatuurgegevens, warin van een daling wordt melding gemaakt. 
7.3. DE ENQUETE- EN DE INTERVIEWGEGEVENS VAN DE HUISARTSEN OVER HET GEVEN VAN EEEDBACK.

In de enquête is de huisartsen gevraagd naar hun appreciatie van de gegeven feedback. In de interviews werd eveneens ingegaan op de gegeven of mogelijk gewenste feedback.

\section{- Enquetegegevens over feedback.}

Vanaf het begin van het E.D.C. werden de evaluatiegegevens gepresenteerd via het Informatiebulletin en op de klinische agora bí.jeenkomsten *

Rujm 60\% van de huisartsen gaf te kennen de evaluatie-gegevens bj.j voorkeur zowel via het informatiebulletin als op de klinische agora bijeenkomsten te willen ontvangen. Voor $30 \%$ van de huisartsen zou de informatie-verstrekking over de evaluatie-gegevens alleen maar via het bulletin hoeven te gebeuren.

Verwonderlijk is, dat geen erkele huisarts alleen maar voorkeur voor feedback via de klinische agora aangeeft, terwijl toch door de meerderheid een voorkeur wordt aangegeven voor een combinatie van informatiebulletin plus klinische agora!

Het Informatiebulletin van het Diagnostisch Centrum is in deze duidelijk van groter belang dan de klinische agora bijeenkomsten.

Aanvankelijk werd, zoals vermeld, aan de huisartsen globale individuele feedback gegeven over het al dan niet toepassen van de werkafspraken (zi.e schema 7.1. ).

De mate warin de huisartsen deze globale feedback warderen is in tabe 1 7.4, weergegeven.

TABEL 7.4 .

Waardering door geenqueteerde huisartsen van globale individuele feedback over toepassing van werkafspraken $(8)$

warardevol

61

van geringe waarde

19

van geen waarde

niet ingevuld

11 
In hun toelichting van bovengenoemale antwoorden gaven een negental huisartsen aan de feedback juist te waarderen vanwege het bevorderen van een kritische houding ten opzichte van eigen werk en vanwege de stimulering welke uitgaat van de feedback.

Daarentegen vonden acht huisartsen de feedback te getalsmatig. gebaseerd op te weinig materiaal of te globaal. (bv. algemeen wel wardevol, alleen jammer dat je niet weet in welke gevallen je je niet aan de werkafspraken hebt gehouden).

Voor de aanvragen voor leverfunctietests werd zoals aangegeven meer gerichte individuele feedback aan de huisartsen verstrekt (zie schema 7.2.$)$.

Tabel 7.5. laat zien in welke mate deze meer gerichte individuele feedback door de huisartsen is gewardeerd.

TABEL 7.5 .

Waadering door huisartsen van meer gerichte individuele feedback zoals aangegeven, voor aanvragen leverfunctietests (z)

waardevol

68

van geringe warde

22

van geen waarde

niet ingevuld

totaal

100

Opvallend is dat een groot aantal huisartsen meer gerichte feedback wardevollex vindt an globale feedback. In hun verklaring van bovengenoemde antwoorden werd door vijf huisartsen naar voren gebracht, dat zij juist graag willen weten waar de fout $z i t$ in de aanvraag *

Drie huisartsen vonden deze meer gerichte feedback van geen warae: te eenzijdig, te getalsmatig en te lncidenteel.

Door het Diagnostisch Centrum werd er rekening mee gehouden, dat de meer gerichte individuele feedback door een antal huisartsen vervelend zou worden gevonden. Door slechts enkele huisartsen wordt dit inderdaad bevestigd. Ruim 858 evenwel wond de wijze, warop tot nu toe de meer gerichte individuele feedback, zoals gegeven voor de aanvragen leverfunctietests werd gegeven, voor henzelf niet vervelend. 
Ongeveer $30 \%$ van de huisartsen gaf tensiotte te kennen, dat zij de feedback graag op een andere wiljze zouden willen ontvangen. ult de opmerkingen kwam naar voren, dat een groot aantal huisartben het op prijs zou stellen, indien gerichte individuele feedback gekoppeld zou worden aan de onderzoekaanvragen, zo mogelijk gerelateerd aan het patiënten probleem. De feedback dient concreet van aard te zijn, aan te geven waar niet volgens de afspraak is gehandeld of war het fout is gegaan, niet alleen te attenderen war het gedrag afwijkend is, mar tevens erbij te vermelden hoe het wel moet en met alternatieven aan te geven hoe de handelwijze veranderd/verbeterd kan worden. Er is eveneens behoefte aan relatering van eigen aanvraaggedrag aan dat van andere hui sartsen.

De mogelijkheid tot mondelinge toelichting wordt op prijs gesteld. Een alternatief hiervoor zou kunnen zijn bespreking in kleine groepen.

Het is zinvol hier, in dit verband, naar voren te brengen, dat vanaf medio 1985, vanuit het Diagnostisch Centrum, wederom individuele feedback aan de huisartsen wordt verstrekt. Deze feedback verstrekking. gegeven door de coördinator van het Diagnostisch Centrum, komt in grote lijnen tegemoet aan bovenvermelde wensen. In concreto wordt de navolgende handelwijze gevolgd: op toerbeurt wordt aan iedere huisarts schriftelijk feedback gegeven over zijn onderzoekaanvragen van één maand.

In deze feedback aan de huisarts komen de volgende onderwerpen an de orde:

- Het aantal onderzoekaanvragen van de huisarts in de besproken maand; een vergelijking van dit aantal aanvragen met dat van een eventuele voorgaande rapportage en met het gemiddelde van de huisartsen uit deze periode.

- Een beoordeling van de mate en kwaliteit van verstrekking van gegevens op het DC-formulier.

- Een bespreking van de aangevraagde diagnostiek in het algemeen en ten aanzien van individuele patiënten in het bijzonder.

Betreffende de diagnostiek in het algemeen kunnen opmerkingen gemakt worden en kanttekeningen worden geplaatst bij de volgende zaken: 
- opvallend frequente, danwel zeer incidentele aanvragen van bepaalde soorten onderzoek;

- over-diagnostiek of niet correcte diagnostiek bij bepalde symptomen en ziektebeelden;

- de diagnostiek van vage klachten bij jonge patiënten, waarbij lichamelijk onderzoek geen afwijkingen oplevert;

- omschreven onderzoek van nierfunctie, levertests, schildklierfunctie, röntgenonderzoek versus endoscopie e.d.;

- onnodig onderzoek wanneer de resultaten van aangevraagde diagnostiek niet leiden tot verandering in het beleid van de huisarts;

- kosten van onderzoek bij over-diagnostiek e.d.

Ten aanzien van de aangevraagde diagnostiek van de individuele patiënten wordt de diagnostiek van een aantal patiënten besproken, waarbij onder andere aan de orde kan worden gesteld:

- de relatie klachten/bevindingen bij lichamelijk onderzoek/diagnose/aangevraagde diagnostiek;

- een andere diagnostische benadering van het probleem;

- advies voor aanvullende diagnostiek;

- items zoals vermeld onder bespreking van de diagnostiek in het algemeen.

- De rapportage wordt vervolgd met enkele vragen naar het beleid van de huisarts na ontvangst van al dan niet afwijkend laboratorium-, röntgenonderzoek e.d.

- Aan de huisarts wordt tenslotte gevraagd te willen reageren met commentar op deze rapportage van zijn diagnostisch handelen. De reacties zijn in het algemeen zeer positief geweest.

\section{- Interviewgegevens over de feedback.}

In de enquête is door een aantal huisartsen naar voren gebracht, dat zij nogal kritisch staan ten opzichte van de gegeven feedback en de feedback liever op een andere wijze zouden ontvangen. Ui.t de interviews kont een vrijwel identiek beeld naar voren (zie tabe1 7.6.$)$. 
TABEL 7.6 .

Wardering feedback door 47 geinterviewde huisartsen. (g)

\begin{tabular}{ll|} 
zeer positief & \\
positief & \\
noch positief, noch negatief & \\
\hline negatief &
\end{tabular}

Als aanvullende bemerkingen over de feedback komen uit de intervilews naar voren:

- De feedback dient primair voor de huisartsen zin te hebben en niet voor het Diagnostisch Centrum.

- Indien de feedback maar gedurende bepaalde tijd gegeven wordt, areigt spoedig verwatering.

- Meer behoefte aan inhoudelijke feedback.

- Feedback heeft op zichzelf al een stimulerende functie. Je gaat in ieder geval een tijdje bewuster handelen. Houdt het systeem in leven. Werkt verfisisend. Je wordt alert voor je fouten.

- De feedback geeft stimulans om werkafspraken weer eens na te gaan kijken.

- Voor een aantal huisartsen is de feedback minder relevant, omdat ze al goed scoren.

- Procentueel gegeven feedback kan aanleiding geven om zo te gaan handelen, dat de score beter wordt.

- De feedback is voor sommige huisartsen niet zo zinvol, ondat er altijd wel een reden is om van de werkafsprak af te wijken.

Samenvattend komen uit de enquête- en de interviewgegevens, ten aanzien van het geven van individuele feedback aan huisartsen over de toepassing van de werkafspraken, met name de navolgende zaken naar voren:

- Bij de presentatie van de evaluatiegegevens van het Diagnostisch centrum wordt door de huisartsen een grotere plats toebedacht aan het Informatie bulletin dan aan de klinische agora bijeenkomsten. 
- Zowel uit de enquêtegegevens als uit de interviewgegevens komt naar voren, dat door bijna $70 \%$ van de huisartsen het krijgen van individuele feedback op prijs wordt gesteld.

- Door nog geen $10 \%$ van de huisartsen wordt het krijgen van individuele feedback als vervelend ervaren.

- Door een aantal huisartsen worden concrete adviezen aangereikt om het effect van het geven van individuele feedback te verbeteren. 
8. SAMENVATTING EN AANBEVELINGEN.

\subsection{SAMENVATTLNG.}

- De context en de vraagstelling van het onderzoek.

Het onderzoek is opgezet met het doel een bijarage te leveren aan de versterking van de eerste lijn. In vele discussies het medisch handelen betreffende wordt het gebruik van werkafspraken in de geneeskunde bepleit. Het onderzoek heeft betrekking op de samenwerking van de huisarts met de specialist bij de totstandkoming en de toepasing door huisartsen van werkafspraken ten anzien van het gebruik van diagnostische faciliteiten van een Diagnostisch Centrum. In de werkafspraken kan aan de samenwerking van de huisarts met de specialist meer vorm en inhoud gegeven worden. wil de huisarts binnen de eerste lijn zijn centrale plaats kunnen vervulien, dan zal hij intensief dienen samen te werken met specialisten van het tweede echelon.

Vanuit zowel de huisartsen als de specialisten is er de latste jaren een toenemende roep om verbetering van de onderlinge samenwerking. Aan samenwerkingsdoelen tussen ziekenhuis en eerste lijn, evenals aan concrete samenwerkingsvormen tussen huisarts en specialist, kan op diverse wijzen vorm en inhoud gegeven worden. Naast positieve geluiden omtrent exvaringen in deze samenwerking, worden ook kritische bemerkingen gehoord.

Ter verbetering van de samenwerking huisarts - specialist, zijn dan ook experimenten met samenwerkingsvormen wenselijk. Van overheidswege werd gedacht an experimenten met Diagnostische Centra. In het Experiment Diagnostisch Centrum Maastricht is een aantal nieuwe samenwerkingsvormen tussen huisarts en specialist opgezet. Een van de doelsteliingen van het E.D.C.M. is: een meer doeltreffend en doelmatig gebruik van diagnostische faciliteiten voor de huisarts in het ziekenhuis te bevorderen, met gezamenlijk door huisarts en specialist opgestelde werkafspraken.

Tussentijdse evaluatiegegevens brachten naar voren, dat de werkafspraken slechts in beperkte mate worden toegepast. Meer kennis 
van de factoren, welke de toepassing van werkafspraken beworderen leek nodig.

Literatuur oriëntatie verschaft wel informatie ontrent het gebruik van diagnostische ziekenhuis-faciliteiten door (huis)artsen, mar vrijwel geen gegevens omtrent factoren welke van invloed zijn op de toepassing van werkafspraken voor diagnostische onderzoeken. Als methoden, die het medisch handelen van artsen kunnen beinvloeden, worden vermeld: de hantering van richtlijnen, de beoordeling van het practische handelen en het geven van feedback.

Als vraagstelling van het onderzoek is gekozen voor een explorerend onderzoek naar de factoren, welke van invloed $z i j n$ op de toepassing van werkafspraken betreffende het gebruik van diagnostische faciliteiten van het ziekenhuis door muisartsen.

Aangezien uit de literatuurstudie weinig informatie over toepassingspatronen van werkafspraken door huisartsen naar voren kwam, was oriëntatie over andere gedragspatronen in het medisch handelen van huisartsen en factoren, welke hierop van invloed zijn, wenselijk.

Vanuit een drietal invalshoeken zijn factoren geinventariseerd:

- Het verwijzen van de huisarts naar de specialist.

- Het voorschrijfgedrag van (huis)artsen.

- Ervaringen van de huisartsen met de toepassing van werkafspraken vanuit het Diagnostisch Centrum.

Uiteindelijk konden de aldus geinventariseerde factoren in een negental categorieën samengevat en gegroepeerd worden.

\section{- De onderzoeksopzet.}

Vanuit het Diagnostisch Centrum is een achttal werkafspraken bij de huisartsen geintroduceerd. Op grond van een aantal argumenten is voor het onderzoek gekozen voor de bestudering van twee van de acht werkafspraken: afspraken aanvragen ECG en aanvragen leverfunctietests.

Met behulp van de D.C.-aanvraagformulieren was het mogelijk de toepassing van de werkafspraken door de hulsartsen te beoordelen. 
De betreffende 44 huisartsen zijn ingedeeld in arie groepen, respectievelijk met een hoog, matig en een laag toepassingspercentage. Vanuit deze groepsindeling van de huisartsen is vervolgens geëxploreerd, welke factoren de groepen huisartsen onderscheiden.

Bij de verzameling van gegevens betreffende de factoren van invloed op de toepassing van de werkfspraken is een drietal meetinstrumenten gehanteerd: de enquête, het interview en bronnen over algemene gegevens over de huisartsen en hun praktijk.

Als referentie voor de huisartsgeneeskundige beoordeling van de inhoud van de werkafspraken door de met het Diagnostisch Centrum samenwerkende huisartsen, zijn de wragen van de enquête die hierop betrekking hadden, eveneens voorgelegd aan 40 geselecteerde huisartsen, verspreid over heel Nederland.

Met het interview was het mogelijk informatie te verkrijgen ontrent de vraag warom de huisartsen in concrete situaties de werkafspraken niet of onvolledig toepassen. Het interview kon tevens een soort "sleepnetfunctie" vervullen ten opzichte van de middels de enquête verkregen informatie.

De algemene gegevens over de huisartsen en hun praktijk waren beschikbaar in het gegevensbestand van het Diagnostisch Centrum.

- De resultaten van het onderzoek.

De enguête is an de 67 van het Diagnostisch Centrum gebruik makende huisartsen aangeboden. Van 56 huisartsen werd de enquête ingevula terugontvangen.

De gegevens van de enquête geven derhalve de mening weer van ongeveer 83\% van de van het Diagnostisch Centrum gebruikmakende huisartsen. Zowel de grote respons op de enquête, als de wijze warop de enquêteformulieren zijn ingevuld, weexspiegelt de grote betrokkenheid van de huisartsen met het Diagnostisch Centrum. De navolgende specifieke bevindingen $z i j n$ vermeldenswaard: 
- Van de huisartsen vindt 858, dat de centrale coôrdinatie van alle diagnostische aanvragen zowel voor hen telf als voor de patiënt alleen maar voordelen heeft; $25 \%$ van de huisartsen zou nog verdergaande doelstellingen aan het Diagnostisch Centrum toegevoegd willen zien, gericht op de versterking van de eerste lijn en op de verbetering van de communicatie van de eerste en tweede lijn.

- Van de huisartsen wenst $75{ }^{\circ}$ uitbreiding van de diagnostische mogelijkheden van het Diagnostisch Centrum. Met name geldt dit voor inspannings-ECG, allergietesten, audiometrie en in lets mindere mate voor longfunctieonderzoek.

- Toetsing middels de werkafspraken van eigen handelen, als ook bevordering van de taakafsteming van huisarts en specialist, vindt bijna $90 \%$ van de huisartsen gewenst. Het Diagnostisch Centrum wordt bij uitstek in staat geacht zowel huisartsen als specialisten bij het gebruik en de toepassing van de werkafspraken te betrekken. Voorts vindt ongeveer 85 van de huisartsen, dat het Diagnostisch Centrum zorg kan aragen voor een goede evaluatie van de toepassing van de werkafspraken. Ruim $60 \%$ vindt de gegeven globale individuele feedback waardevol. Van de overige $40 \%$ zou het merendeel nog meer gerichte feedback willen ontvangen.

- Voorts geeft ruim 808 van de huisartsen aan, dat de werkafspraken ertoe geleid hebben, dat zij een meer doeltreffend en doelmatig gebruik maken van de diagnostische voorzieningen bij hum practisch handelen en dat het Diagnostisch Centrum ertoe heeft bijgedragen, dat zij meer dan voorheen zicht hebben gekregen op het gebruik van diagnostische onderzoeken. Bijna 80\% geeft aan, dat zij ten aanzien van de diagnostiek en de contrôle, patiënten langer "in eigen hand" kunnen houden. Volgens 60 zijn de verwijzingen nar de specialist afgenomen doot de toepassing van de werkafspraken. Voor zover zij alsmog verwijzen, vindt ongeveer $90 \%$ van de hulsartsen, dat dit dan gebeurt vanuit meer gerichte vraagstellingen. 
In de interviews wordt door de huisartsen een groot antal redenen nat voren gebracht, warom zij in concrete situaties de werkafsprken toch niet volledig toepassen. Hierbij worden door hen in een groot aantal gevallen (circa 478) artsgebonden factoren naar voren gebracht, zoals: vergeten van de werkafspraak, siorig invullen wan de aanvragformulieren tijasdruk en routine. Vervolgens blijken patiěntgebonden factoren (circa 198) en factoren het Diagnostisch Centrum betreffende (circa 18\%) een rol te spejer.

\section{- Samenhang van de onderzoeksvariabelen.}

Uit de analyse van de samenhangen tussen de enquêtegegevens en de toepassing van de werkafspraken komt naar voren, dat de enquête door de huisartsen op vrijwel alle onderdelen statistisch matig tot goed betrouwbar is ingevuld. Dit geldt eveneens yoor de invulling van de enquête door de referentiegroep van Nederlandse huisartsen.

Op grond hiervan was het mogelijk het anvankelijk grote aantal variabelen van de enquête door middel van somscores te reduceren tot 15 somvariabelen.

Bij de analyse van samenhangen tussen deze nieuwe somvariabelen en de groepen van huisartsen, ingedeeld nar toepassingspercentage, zijn allereerst de overschrijdingskans-berekeningen volgens de Kruskall-Wallis-toets en de Mann-Whitney-toets uitgevoerd. Hierna zijn discriminantanalyses uitgevoerd. Eveneens zijn discriminantanalyses uitgevoerd op grond van een F-toets (toelatingacriterium) en met uitsluiting var de meest dominerende variabelen.

Uit deze analyses kwam naar voren dat, in volgorde van onderscheidend vermogen, de navolgende variabelen de groepen huisartsen, met een hoog en een laag toepassingspercentage, goed onderscheiden.

Een hoog toepassingspercentages gat gepaard met: 
- positieve appreciatie organisatie Diagnostisch Centrum

- accordatie werkafsprak leverfunctietests

- werken met afspraakspreekuur

- positieve appreciatie feedback.

Daarnaast heeft zowel de groep hullsartsen met een hoog toepassingspercentage, als de groep huisartsen met een laag toepassingspercentage een kleinere praktijk dan de groep huisartsen met een matig toepassingspercentage (controlegroep).

Bij de onderscheiding van de drie groepen huisartsen bleken eveneens alle bovengenoemde variabelen, met uitzondering van de variabele afspraakspreekuur, van belang. Daarnaast kwam hierbij naar voren, dat een hoog toepassingspercentage gepard gaat met een negatieve appreciatie van protocollen in het algemeen en met een positieve appreciatie van de totstandkoming van werkafspraken vanuit het Diagnostisch Centrum.

Om te bezien in hoeverre de resultaten van de discriminantanalyses in staat waren de huisartsen te classificeren, zijn de discriminantanalyses nog geevalueerd met behulp van een tweetal classificatie matrices. Hieruit bleek, dat met name de variabelen uit de discriminantanalyse van de 2 groepen huisartsen met een hoog en een laag toepassingspercentage goed in stat zijn, de huisartsen naar toepassingspercentage van de werkafspraken te onderscheiden.

Uit de analyse van de samenhangen tussen de enquêtegegevens van de huisartsen, die gebruik maken van het Diagnostisch centrum en de enquêtegegevens van de referentiegroep van huisartsen, kwam naar voren, dat tussen beide groepen vrijwel geen verschil aantoonbaar is ten anzien van de appreciatie van protocollen en werkafspraken in het algemeen.

Wel zijn er verschilien betreffende de accordatie, op inhoudelijke huisartsgeneeskundige gronder, van de beide werkafspraken. Voor de werkafspraak voor ECG-aanvragen zijn deze verschillen vaor een groot deel verklaarbaar uit een andere interpretatie van een onderdeel van de werkafspraak. De geconstateerde grote ver- 
schilen ten aanzien van aanvagen leverfunctietests, zijn verklaarbaar, doordat de invoering en het gebruik van de werkafspraak ertoe heeft geleid, dat de huisartsen, die samenwerken met het Dilagnostisch Centrum, op dit diagnostisch onderzoek meer zicht hebben gekregen dan de huisartsen van de referentiegroep.

Uit de analyse van de samenhangen tussen de interviewgegevens met. de toepassing van de werkafspraken kwam weinig eenduidïge informatie nat voren.

Door de huisartsen met een hoge toepassingsscore worden vaker factoren vanuit het medisch handelen als reden genoemd voor het niet toepassen van de werkafspraken dan door de huisartsen uit de groep met een laag toepassingspercentage, bijvoorbeela: multipele pathólogie, patiënt die je niet vaak ziet, vage klachten, ernstige pathologie, bepallde ziektebeelden en bij controles. De huisartien met een lage toepassingsscore brengen vaker artsgebonden factoren als vergeetachtigheid, slordigheid, routine en tijasdruk als reden naar voren.

De huisartsen met een laag toepassingspercentage geven ook vaker aan de werkafspraken slechts als een richtiljn te willen zien.

De huisartsen met een hoog toepassingspercentage brengen vaker naar voren, dat ze de werkafspraken nog regelmatig opnieuw bekijken.

Tenslotte wordt door de huisartsen met een lage score in een groter aantal gevalien de wens te kennen gegeven om meer gerichte feedback te krijgen.

Bij de analyse van de samenhangen tussen de algemene gegevens over de huisartsen en hun praktijk en de toepassing van de werkafspraken worden de volgende verschillen vastgesteld:

- hulsartsen met een hoog toepasingspercentage hadden een circa $10 \%$ kleinere praktijkgrootte dan huisartsen met een laag toepassingspercentage:

- de praktijken van de huisartsen met een hoog toepassingspercentage hadden een bedulidend hogere urbanisatiegraad dan de praktijken wan de huisartsen met een laag toepassingspercentage; 
- huisartsen met een hoog toepassingspercentage vroegen circa 80 minder onderzoeken in het geheel a an bij het biagnostisch Centrum dan huisartsen met een laag toepassingspercentage;

- huisartsen met een hoog toepassingspercentage hadden een circa I2: lager totaal verwijsciffer dan huisartsen met een lag toepassingspercentage:

- huisartsen met een hoog toepassingspercentage hadden een ruim 20\% lager verwijscijfer nar een van de twee specialismen. warop één van de 2 werkafspraken betrekking had, respectievelijk afdeling interne geneeskunde en werkafspraak voor leverfunctietests.

\subsection{AANBEVELINGEN.}

Een van de hoofddoelstelingen van het Experiment Diagnostisch Centrum luidt: "Meer doeltreffend en doelmatig gebruik te realiseren wan de diagnostische voorzieningen door de huisartsen".

Het E.D.C.M. tracht dit te realiseren met vanuit gezamenlijk overleg tussen huisartsen en specialisten samengestelde werkafspraken. De literatuurgegevens over de toepassing van werkafspraken en protocollen betreffen vijwel uitsluitend meninger en visies zonder de nodige wetenschappelijke onderbouwing. Zo was er tot nu toe nog geen studie naar de vraagstelling van dit onderzoek: welke factoren zijn van invloed op de toepassing door huisartsen van werkafspraken huisarts - specialist woor diagnostisch onderzoek?

Mede op grond van de resultaten van dit onderzoek kom ik ten anzien van de toepassing door huisartsen van werkafspraken tussen huisarts en specialist tot de volgende aanbevelingen:

1. Toepassing van werkafspraken voor diagnostische onderzoeken leidt tot een meer doeltreffend en doelmatig gebruik van diagnostische voorzieningen door de huisarts. Bovendien zijn er aanwijzingen dat de toepasing van de werkafspraken door de huisarts gepaard gaat met een laag en meer doeltreffend verwijzingspatroon van de huisarts. De hantering van de werkafspraken 
versterkt op deze wjze adeguat het huisartsgeneeskundig handeyen.

De toepasing wan werkafspraken dient gestimuleerd te worden.

2. Een "institurt", dat de toepassing van werkafspraken wil implementeren zal de grootste aandacht dienen te schenken aan een de doelgroep convenierende organisatorische opzet. Vanaf de startfase van een dergelijk "instituut" dienen de huisartsen zelf ten nauwse betrokken te worden bij het bepalen van organisatorische zaken, als vorm van aanvaagformulieren, wijze van gegevensverzameling, vorm van informatieverstrekking, enz. Hiemee kan de eigen verantwordelijkheid van de huisartsen voor de hantering van werkafspraken extra gewicht krijgen. De gekozen opzet zal regelmatig gezamenlijk op doelmatigheid geëvalueerd dienen te worden. Eveneens is het van groot belang er zorg voor te dragen dat in de opzet van een dergelijk "instituut" een zekere kleinschaligheid wordt gehanteerd in die zin, dat de afstand tot de localisaties van de praktijken van de deelnemende huisartsen tot het instituut niet te groot is.

3. Het is bovendien werselijk bij de samenstelling van de toe te passen werkatspraken te stxeven naar een zo groot mogelijke accordatie door de huisartsen van de werkafspraken inhoudelijk vakmatig. Aan consensusverwerving en informatieverstreking dienangande, dient grote zorg besteed te worden. Eij de evaLutie van de handelwijze van de huisarts tot dan toe en bij het vaststelien van de gewenste handelwijze zulien huisartsgeneeskundige argumenten een cruciale rol dienen te spelen. Het is van belang, dat specialistische deskundigheid en epidemiologische gegevens darin een complementaire rol vervulien.

Bij de uiteindelijke opsteling van de werkafspraken is het zinvol eveneens grote aandacht te schenken aan met name de mavolgende aspecten: de werkafspraak dient beknopt en overzichtelijk te zijn en de aanbevolen werkwijze dient door de huisartsen als practisch halbaar te worden ervaren. 
4. Gezien het feit, dat bij de toepassing van de werkafspraken, individuele feedback wordt gemist, is het wenselijk hieraan aandacht te besteden bij de effectuering van de werkafspraken. Gegevens over de aan de huisartsen verstrekte individuele Eeedback, doen verwachten, at het mogelijk is met individueel gerichte feedback het toepassingspatroon van huisartsen van werkafspraken blijvend te verbeteren.

5. In werkafspraken wordt aan de samenwerking tussen huisarts en specialist vorm en inhoud gegeven. Een samenwerking welke de mogelijkheid biedt tot een op elkaar aansluitende zorg van huis arts en specialist. Werkafspraken zijn op vele terreinen van de geneeskunde toe te passen; ten aanzien van het anamnestisch handelen, het diagnostisch handelen, het therapeutisch handelen, de begeleiding door de arts en combinaties hiervan. Op basis van werkafspraken kan duidelijkheid ontstaan over ieders rol en verantwoordelijkheid. Vanuit de samenwerking ten anzien van werkafspraken kunnen meerdere samenwerkingsvormen tussen huisartsen en specialisten in gang gezet worden, zoals gestructureerde telefonische consultatie, gezamenlijke consult huisarts-patientspecialist in de huisartspraktijk, specialistisch consult aan huis voor bepalde patiëntengroepen, multidisciplinair consult van de geriatrische patiënt, huisartsgeneeskundig consult in het ziekenhuis, verwijzing voor éenmalig specialistisch consult, structurering informatie verstrekking huisarts - specialist, eto.

6. Voor de realisering van bovengenoemde aambevelingen is en centrale coördinatie vanuit een "instituut" onontbeerlijk. Een "instituut" als beleidsvoorbereidend en -uitvoerend organ. Doelstellingen zullen ontwikkeld dienen te worden en hieruit voortvloeiend moeten actieplannen in gang gezet worden. Hiervoor zijn financiele middelen en mankracht onontbeerlijk. Centrale registratie zal immers dienen plaats te vinden. Eerst dan kunnen de nodige gegevens verzameld, verwerkt en zo rogelijk gearialyseerd worden. Op basis hiervan is evaluatie mogelijk. Evaluatiegegevens welke als feedback aan de deelnemende huisurtsen en 
apecilisten verstrekt kunnen worden. Met behulp van de hierop volgende respons van de participanten kunnen de doelstellingen. de gekozen opzet en actieplannen zonodig bijgesteld of vernieuwd worden.

Een Diagnostisch Coördinerend Centrum is bijuitstek in stat als centraal instituut te functioneren. Een Diagnostisch Coordinerend centruk gelocaliseerd ahaerent aan een ziekenhuis als een transmural instituut, zowel ten dienste van de extramurale als van de intramurale gezondheidszorg. Een Diagnostisch Centrum kan van daruit zowel huisartsen als specialisten bij de algehele opzet. en uitwerking betrekken.

7. De oprichting van Diagnostische Centra dient daadwerkelijk gestimuleerd te worden. Dit is een zak van huisartsen en specialisten, van de ziekenhuizen en van de overheid. Met werkafspraken en andere samenwerkingsvormen tussen huisartsen en specialisten kan erwoor zorg gedragen worden, dat de ongewenste, de laatste decennia eerder toe-" dan afnemende afstand tussen de huisartsgeneeskundige en de specialistische gezondheidszorg, niet nog verder toeneemt. Noch de overheid, noch de beroepsgroepen en allerminst de patiënten zijn gebaat bij een niet op elkaar afgestemde, mogelijk zelfs wedijverende zorgverlening van huisarts en specialist. Werkafspraken tussen huisartsen en specialisten middels Diagnostische Centra opgesteld in gezamenlijk overleg. kunnen de basis vormen van een complementaire gezondheidszorg verlening. 
SLMMARY AND RECOMMENDATIONS.

Sumary.

- The context and the hypothesis of the research.

The objective of this research is to contrjbute to the strenghtening of the primary health care. In numerous discussions on the medical practice, the utilization of professional procedure agreenents in the medical science is advocated. The research is concerned with the cooperation of the general practjtioner wjth the specialist in the implementation and application of professional procedure agreements by general practitioners. These profesgional procedure agreements are related to the utilization of diagnostic faclilities at a Diagnostic Centre. Professional procedure agreements can contribute both to the form and the contents of the cooperation of the general practitioner with the specialist. If the general practitioner wants to be able to fullfill his central role in the primary health care, he is required to cooperate intensively with the specialists of the hospital care.

The last couple of years, both general practitioners and specialists have placed an increasing demand for an improvement of their cooperation. There are several ways to achieve the cooperation objectives between the hospittal and the primary health care, as well as to realize concrete cooperation activities between the general practitioner and the speciallist. "These cooperation activities have been experienced both positively and negativeIy. Thus, jin order to improve the cooperation between the general practitioner and the specialist, experiments with cooperation activities are desirable. The Dutch government proposed experiments with Diagnostic Centres. A number of new cooperation activities between general practitioners and specialjists have been developed in the Diagnostic Centre of Mastricht Experiment (E.D.C.M.). One of the objectives of the E.D.C.M. is to promote a more efficient use of djagnostic facjlities in the hospital for the general practitioner, by the implementation of professional procedure agreements by both general practitioner and specialist. Interim evaluation findings reported that the professional procedure agreenents are only applied to a limited extent. More knowledge seemed to be necessary of the factors which stimulate the application of the professional procedure agrements. Information on the utilization of diagnostic hospltal facilitjes by physicjans / general practitioners can be found in the literature, but there are virtually no data on the factors which influence the application of professional procedure agreenents for diagnostic researches. Factors which can influence the medical performance of physicians are mentioned as follows: using guidelines, assessing the medical practice and supplying feedback. This research note presents an exploring research into the factors wich influence the application of professional procedure agreenents related to the utilization of diagnostic hospital facilities by general practitioners.

As the literature research did not present much information about the application patterns of professional procedure agreenents by general practitioners, it was desirable to identify other behaviour patterns in the medical performance of general practitioners and their major factors. The factors which have been collected are related to the following three points: 
* The referral by the general practitioner to the specialist.

* The prescribing behaviour of the physician / general practitioner.

* The general practitioner"s experiences with the application of the professional procedure agreenents from the Diagnostic Centre.

gventually, the ljsted factors could be sumarized and ranked into nine categories.

\section{- The research model.}

The Dilagnostic Centre has introduced ejght professional procedure agreements to the general practitioners. For a number of reasons, the research deals with the exarination of the following two of the eight professional procedure agreentents:

* agrements on applications for ECG;

* agreenents on applications for lever function tests.

The Diagnosti.c Centre appli.cation forms were used to assess the application of the professional procedure agreements by the general practitioners. The 44 general practitioners in question are divided into three groups: respectively with a high, a moderate and a low application percentage. This divj.sion of groups fonned a base for the analysis of the factors which distinguish the groups of general practitioners.

In order to collect the findjings concerning the factors which influence the application of the professional procedure agreements, the following measure techniques have been employed:

* the survey

* the interview

* sources of general data on the general practitioners and their practice.

In order to assess the representativeness of the professional procedure agreements (a cooperation between the general practitioners and the Diagnostic Centre of Masitricht), the relevant questions of the survey have also been subnitted to a referance group of 40 selected general practjtioners, distributed all over the Netherlands.

The interviews made jit possible to identify the reasons why the general practitioners did not use or inadequatly used the professional procedure agrements in concrete situations. The interview was also very useful in collecting infonnation which was not obtained by means of the survey.

The general data or the general practitioners and their practice were avallable from the data base of the Diagnostic Centre.

- The results of the research.

The survey questionnaires have been offered to the 67 general practitioners, who make use of the Diagnostic Centre, 56 of which were completed and returned. The data of the survey consequently represent the opinion of approximately 838 of the general practitioners who make use of the Diagnostic Centre. The considerable response to the survey, as well as the way in which the survey questionnaires have been completed, reflects the great participation of the general practitioners into the Diagnostic Centre. The following specific findings are worth mentioning: 
* 85\% of the general practitioners finds that the central planning of all diagnostic requests only has advantages for the patients as well as for themselves: $25 \%$ of the general practitioners would like to see more exploring objectives assigned to the Diagnostic Centre, focused upon the strenghtening of the primary health care and upon the iniprovement of the communication between the primary health care and the hospital care.

* 758 wishes the increase of the diagnostic possibilities of the Diagnostic Centre. More specificly: diagnostic facilities for exertion BCG, allergY tests, audionetry and to a lesser extent for lung function research.

* Almost $90 \%$ of the general practitioners desires a quality assessment of their own perfomance by means of the professilonal procedure agreement as well as a stimulation of the task division between general practitioner and specialist. The Diagnostic Centre is in particulair considered to be suitable to involve both the general practitioners and the specialists into the application of the professional procedure agreements. In addition, approxinately $85 \%$ of the general practitioners finds that the Diagnostic Centre can attend to a good evaluation of the application of the professional procedure agreements. Approximately 60 s finds the global personal feedback valuable. The majority of the other 40 s would like to have an even more specific feedback.

* In addition, largely $80 \%$ of the general practitioners concludes that the professional procedure agrements allowed them to make more efficiently use of the diagnostic facilitjes in thejr medicall practice and that the Diagnostic Centre contributed to a better view on the application of the diagnostic researches. Almost 308 notes that in the case of diagnostic procedures and medical control, they can keep thejr patients in "thej.r ow hands". According to 60\%, referrals to the specialists have been reduced by the application of the professional procedure agreements. In case the general practitioners still refer to specialists, 90 of them

finds that it is realized by asking more specific questions.

In the interviews, the general practitioners give a great number of reasons Why they do not adequatly use professional procedure agreements in concrete situations. In a great number of cases (approximately 478) factors are mentioned which are related to the physician, as for example: having forgotten the procedure agreenent, having carelessly completed the application forms, having time preessure and routine. Other factors which play a role are those related to the patjent (approximately 198) and factors which are related to the Diagnostic Centre (approximately 188).

- Coherence of the research variables.

From the analysis of the coherences between the survey findings and the application of the professional procedure agreements, it can be concluded that virtually all items of the survey questionnajre have been completed by the general practitioners and that the outcome is statistically from moderately to adequatly representative. This can also be stated for the gurvey questionnaire completed by the reference group of Dutch general practitioners. On this basj.s j.t was possible to reduce the jnitial great number of survey variables to 15 sum variables by means of sum scores. Initially, the p-value according to the Kruskall-Wallis test and the Mann-Whitney test has been applied in the analyses of the coherences between the new sum variables and the categorjes of general practitioners ranked according to their application percentage. In addition, discriminant analysises have been applied as well as discrininant analysises based on a F-test (admission criteri.a) exluding the most dominant variables. 
The application of the analysises resulted in the following variables wich adequatly distinguish the categories of general practitioners (factors ranked in sequence of their power).

A high application percentage is irvolved with:

* positive appreciation organilsation Diagnostic Centre

- umderstanding professional procedure agreement lever fumtion test

* consultation by appointment

* positive appreciation feedback.

In addition, the category of general practitioners with a high application percentage and the category of general practitioners with a low application percentage both have a maller practice than the category of general practitioners with a moderate application percentage (verification group).

All above mentioned variables (excluding the variable * consultation by" appointment) turned out to be of importance in distinguishing the three categories of general practitioners. Moreover, a high application percentage turned out to involve a negative appreciation of protocolls in general and a positive appreciation of the implementation of professional procedure agreanents at the Dlagnostic Centre.

In analysing the extent to which the results of the discriminant analysises were suitable to classify the general practitioners, the discriminant analyses have also been evaluated bij means of two classification maicrices. Consequently, especially the variables of the discriminant analysis of the two categorles of general practitioners with a high and a low application percentage, turned out to be adequatly appropriate to distinguish the general practitioners according to the application percentage of the professional procedure agrements.

Fram the analysis of the coherences between the survey findings on the general practitioners who make use of the Diagnostic Centre, and the survey findings on the reference group of general practitioners, it can be concluded that there is virtually no indicated difference between both groups as to the appreciation of protocols and professional procedure agreements in general. The differences which have been found are related to the understanding of both professional procedure agreements based on factors related to the primary health care.

As to the professional procedure agreement for ECG applications, these differences can for the greater part be explained by a different interpretation of an iten of the professional procedure agreenent. The great differences which are related to the lever function tests can be clarified by the fact that the general practitioners who cooperate with the Diagnositic Centre have a better view on this diagnostic procedure than the general. practitioners of the reference group, as a result of the introduction and the utilization of the professional procedure agreements.

The analysis of the coherences between the interview findings on the application of the professional procedure agreements presented little unequivocal information. General practitioners with a high application percentage more often mentioned factors related to their medical performance as a reason to refrain from applying the professional procedure agreenent, than general practitioners with a low application percentage. Examples of these factors are:multiple pathology, patient with no regular consultations, vague complaints, serious pathology, certain diseases and at medical controls. 
The general practitioners with a low application score more frequently mention factors related to the physician himself as for example: being oblivious, careless, having routine and time pressure.

The general practitioners with a low application percentage also state more often that they wish to consider the professional procedure agreements merely as a guideline. Finally general practitioners with a low score remark in a greater number of cases that they wish to receive more specific feediback.

In the analysis of the coherences between the generall findings on the general practitioners and their practice and the application of the professional procedure agreements, the following differences have been identified:

- general pratitioners with a high application percentage had an approximately 108 smaller practice than general practitioners with a low application percentage;

- the practices of general practitioners with a high appli.cation percentage had a remarkably higher urbanisation degree than the practices of general practitioners with a low application percentage;

- general practitioners with a high application percentage applied for approximately $8 \%$ less researches at the Di.agnostic Centre on the whole, than general practitioners with a low application percentage;

- general practitioners with a high application percentage had an approximately 128 lower referral rate than general practitioners with a low applizcation percentage;

- general practitioners with a high application percentage had a largely $20 \%$ lower total referral rate to one of the two specialisms to which one of the two professional procedure agreements were related, respectivvely the internal medecine department and the professional procedure agreement for lever function tests.

\section{Recommendations.}

One of the major objectives of the Diagnostic Centre Experiment is "to realize a more efficient utilization of the diagnostic facilities by the general practitioners".

The Diagnostic Centre of Mastricht Experiment endeavours to realize thig objective by a mutual agreement between general practitioners and specialists, the so-called professional procedure agreenent. The literature findings on the application of application percentages and protocols vilutually only present opinions and viewpoints, without the necessary scientific support. Thus, untilli now no study has been carried out on the hypothesis of this research: "which factors influence the application (by the general practitioners) of the professional procedure agreements (between professional procedure agreement and specialjist) for diagnostic research?" Based, anongst others, on the results of this research, I can give the following recammendations on the application (by general practitioners) of professional procedure agreements between general practitioners and specialists:

1. The application of professional procedure agreenents for diagnostic researches leads to a more efficient utilization of diagnostic facilities by the general practitioners. Besides, there are Indications that the application of these professional procedure agreements by the general practitioners involves a low and more efficient referring pattern of 
the general practitioners. Thus, the utilization and application of the professional procedure agreenents positively stimulates the primary health care. The application of professional procedure agreenents has to be promoted.

2. An "institute" that wants to implement the application of professional procedure agreements, will have to pay the greatest attention to an organisational model that complies wi.th the desires of the target group. Bught from the start of such an institute, the general practitioners have to participate intensely in making organisational decisions like the design of the application forms, the procedure of collecting and distributing data etc. This will give the general practitioners even more regponsabjilities in the application of the professional procedure agreements. The efficiency of the chosen model will have to be frequently evaluated by both the "institute" and the general practitioner. It is also very important that the "institute" in question is established on such a scale that the distance between the geographic situations of the participating general practitioners' practices and the Diagnostic Centre is not to large.

3. In developing the professional procedure agreements, it is also desirable to reach a large possible understanding by the general practitioner of the professional representativeness of the professional procedure agreements. One has to pay a lot of attention to reaching the relevant consensus and distributing the data in question. In the evaluation of the procedure of the general practitjoner so far, and in the determination of the desired procedure, arguments related to the primary health care, shall have to play a crucial role. It is of importance thet specialist expertise and epidemiological data, in addition, play a complementary role. In the final construction of the professional procadure agreements, it is sjinificant to attach the same importance to particularly the following aspects: the professional procedure agreement has to be concise and well-structured and the general practitioners have to experience the recomended procedure as practically realizable.

4. Given the fact that there is a lack of personal feedback in the application of the professional procedure agreements, it is desirable to give itt attention in the realization of the professional procedure agree ments. Findings on the personal feedback offered to the general practitioners let us expect that it is possible to continually improve the application pattern of the general practitioners as to the professional procedure agreements, by means of specific personal feedback.

5. The professional procedure agreements allow the general practitioner and the specialist to cooperate with each other. A cooperation which offers the possibility of a complementary health care of both generall practitioner and speci.ali.st. Professional procedure agreements can be applied to a great many fields of the medical science. For example to anamnestics, diagnostics, therapeutics the physicians guidance and combinations. Professional procedure agreements can offer clarity about each other role and responsability. Professional procedure agreenents, characterized by the cooperation between the general practitioner and the specia1i.st, can give rise to more cooperation activities as structured consultation by telephone, cocperate consultation in the primary health care 
by both general practitioner and specialist, specialistic home-to-home consultation for certain patient groups, multidisciplinary consultation of the geriatric patient, primary health care consultation in the hospital care, referral for one specialistic consultation, structuring distribution information between general practitioner and specialist etc.

6. A centrally coondinated "institute" is indispensable to realize the above mentioned recommendations. An "institute" that prepares and executes its policies. It will have to develop its objectives and acconding1y, to jmplement its plans. This will require the financial means and the man power, because central registration will be necessary. Not untill then, can the necessary data be collected, processed and, if possible, be analysed. This will make evaluation possible. Evaluation findings can be very useful in offering feedback to the general practitioners and specialists who participate. The objectives, the chosen model and the plans can be adjusted, if necessary, or be renewed by means of the participants" reactions upon the feedback. A Diagnostic Coordinating Centre is in partjcular suitable to function as a central institute. A Diagmostic Coordinating Centre that 1 s located attached to an hospital as a transmural institute, is of service to both the extramural health care and the intramural health care. Consequently, a Diagnostic Centre can involve both general practitioners and specialists into the entire model and elaboration.

7. The establishment of Diagnostic Centres has to be actively stimulated. This is a matter of the general practitioners and the specialists, of the hospitals and the Dutch Government. The gap between the primary health care and the hospital care has increased rather than decreased. the last decades. Professional procedure agreements and other cooperation activities between general practitioner and specialist will allow us to stop this undesirable gap from increasing. Neither the Dutch Government nor the medical professional groups and at the least the patients are served by a incoherent, possibly even a competitive health care of general practitioners and specialists. Professional procedure agreements between general practitioner and specialist, framed by mutual consent at Diagnostic Centres can be the basis for a complementary health care service. 


\section{LITERATUURLIJST}

Achong, M.R., Wood, J., Thea 1, H.K., Goldberg, R., Thompson, D.A. Changes in hospital antibiotic therapy after a qualityof-use study. Lancet, 1977; i1: 1118-1122.

Alting von Geusau, W.; Lieshout, V. van; Tielens, V. Huisarts en persoonlijkheid. Medisch Contact 1984; $51: 1663$.

Anerican College of Physicians. Policy Statement, Philadelphia, PA 1978 .

Barnet, G.O., Winickoff, R., Dorsey, J.L., Morgan, M.M., Lurie, R.S. Quality assurance through automated monitoring and concurrent feedback using a computer based medical information system. Medical Care 1978; 16: 962-970.

Becker, M.H., Stolley, P.D. Lasagna, L., McEvilla, J.D., Sloane, L.M. Differential education concerning therapeutics and resultant physicjan prescribing patterns. Journal of Medical Education 1972; 47: 118.

Beek, M.; Eijk, J. van; Rutten, G. Huisarts en specialist over hun onderlinge taakafbakening. Medisch Contact 1984; 39: 1247 .

Beek, M. et al. Verschuiving van eerste naar tweede lijn? Medisch Contact $1985 ; 10: 299$.

Benzodiazepines: use, overuse, misuse, abuse? Lancet 1973; 1 : 1101 .

Beus, C.H. de. Electrocardiografie in een huisartspraktijk. Nijmegen, Katholieke Universiteit $\mathrm{Nijmegen,} 1969$.

Beusmans, G.H.M.I. et al. Medische Facultejt Maastricht en eerste 1.j.j. Medisch Contact 1981; $15: 437$.

Boelen, J.L.A. Kwalitejt medisch handelen. Medisch Contact 1983; 38: 991 .

Bol, F. Diagnostisch Centrum. Medisch Contact 1982; 8: 203 .

Boot, H. Leverfunctie en leverfunctieproef. The Practitioner $1983 ;$ juli: 709 .

Boots, J.: Zutphen, W. van. Taakopvatting van de huisarts. Medisch Contact 1981; $3: 65$.

Boots, J.M.J. Het werk van de huisarts. Maastricht, R.I.: Meerstad 1983 .

Böttiger, L.E., Westerholm, B. Drug-induced blood dyscrasias in Sweden. British Medical. Journal 1973; 3: 339.

Braak, ten, Werf, van der. Medisch Contact 1984.

Brand, H.J. Huilartsen en specjalisten in gesprek over samenwerking. Huisarts en Specialist XIV, discugsie. Medisch Contact 1974; $29: 1035$.

Bremer, G.J.; Westreenen, E. van. De werkzaamheden in de huisartsenpraktijk nu en in de toekomst. Huisarts en Wetenschap $1964 ; 7: 2-17$.

Bremer, G.J. Huisarts en diagnose: Voordracht op het 27 e wetenschappelijke congres van het NHG 1982.

Bremer, G.J. Hulsarts en het verwijzen. Nieuw Kompas voor de Huisarts december 1983; II; 12-1: 9 .

Bremer, G.J. Geneesmiddelen voorschrijven in de huisartsprakti.jk. Medisch Contact $1983 ; 38: 73$.

Brons, R. et al. Diagnostische hulp voor de huisarts bij ischemische hartziekten; Medisch Contact 1981; 26: 793. 
Brook, R.H., Appel, F.A. Quality of care assessment: choosing a method for peer review. New England Journal of Medicine $1973 ; 288: 1323-1329$.

Brouwer, W.: Romme, M.A.J. Faculteit en eerste lijn. Utrecht; Bohn, Scheltema en Holhema 1981 .

Brouwer, W. Diagnostische faciliteiten voor de huisarts. Medisch Contact 1984; 12:359

Brown jr., C.R., Uhl, H.S.M. Mandatory continuing education: sense or nonsense. Journal of the American Medical Association $1970 ; 213: 1660-1668$.

Bruins, C.P. Ondergrondse communicatieproblemen. Huisarts en Specialist XI, discussie. Medisch Contact 1974; 29:937.

Bruins, C.P. Diagnostische Centra. Medisch Contact 1974; $29:$ 1458 .

Buma, J.I. et al. Huisartsgeneeskunde voor en na 1984. Nijmegen; Nijmeegs Unjversitair Huisartsen Instituut 1984.

Burkens, J.C.J. Consultatie in beide richtingen. Huisarts en Specialist IV, discussie. Medisch Contact 1974; 29:705.

Caspari., A.F. Bereiken van een consensus in de geneeskunde (commentaarl. Nederlands Tijdschrift voor Geneeskunde 1983; $127 ; \mathrm{nr} .40: 1816$.

Caspari, A.F. Gestructureerde samenwerking. Medisch Contact 1985; 4: 97 .

Centrale Raad voor de Volksgezondheid. Dlagnostische Centra. nr. 21 uit. de verslagen, adviezen en rapporten 1974 . Ministerie van Volksgezondheid en Milieuhygiene 1974.

Centrale Raad voor de Volksgezondheid. Advies inzake experiment Diagnostisch Centrum. Rijswijk, 15 juni 1975.

Childs, A.W. Hunter, D. Non-medical factors influencing use of diagnostic $x$-ray by physiclans. Medical Care 1972; 10 : 323.

Cronbach, L.J. Coefficient alpha and the internal structure of tests. Psychometrika 1951; 16:297-334.

Daniels, M; Schroeder, S.A. Variation among physicians in use of laboratory tests. Relation to clinical productivity and outcomes of care. Medical Care 1977; $15: 482$.

Demmers, $W$. et al. Een Diagnostisch Centrum bij een algemeen ziekenhuis. Medisch contact 1984; 12:365.

Diagnostisch Centrum Mastricht. Einareportage september 1983.

Discussie "Hoe verwacht een huisarts dat een specialist hem ziet" en vice-versa. Discussie in Medisch Contact. Medisch Contact $1974 ; 13: 1401-1403$.

Dixon, W.J. (et al.). B.M.D.P. Statistical software. University of California, Berkeley, 1981.

Does, E. van der. Samenwerking huisarts-specialist met betrekking tot de patientenzorg in de thans bestaande structuur der gezondheidszorg. Huisarts en Specialist $X$, dicussie. Medisch Contact 1974; $28: 914-915$.

Dombal, F.T. de, Leaper, D.J., Horrocks, J.C., Stanjland, J.R., McCann, A.P. Human and computer-aided diagnosis of abdominal pain: further report with emphasis on performance of clinicians. British Medical Journal 1974; $1: 376-380$.

Donabedian, A. Evaluating the quality of medical care. Milbank Mem. Fund Quarterly $1966 ; 44: 166$. 
Donabedian, A. Using decision analyse to formulate process criteria for quality assessment. Inquiry 1981; 18: 102-119.

Dool, C.W.A. van der. Pro-protocol. Huisarts en wetenschap 1984; $27: 37$.

Dopheide, J.P.; Zee, J. van der. Verwijscijfers en diagnostische Eaciliteiten voor de huisarts. Medisch Contact 1980; 35: 679 .

Dopheide, J.P. Verwijzingen door de huisarts. Gezondheiden Samenleving $1982 ; 3: 141-15$.

Draaisma, A.A.; Mellink, J.E. Overwegingen rond rapport Diagnostische Centra. Unie 1974; 9: 152-154.

Dunne1, K., Cartwright, A. Medicine takers, prescribers and hoarders. Routiedge \& Kegan Paul, London 1972.

Dunning, A.J. Het medisch handelen als proces, "medische besliskunde". Medisch Contact 1984; 9: 269.

Duuren, R.; Hupkens, L.A.J. Verschillen in verwijsgedrag door samenwerkingsverband. Medisch Contact 1981; $36: 1933-1936$.

Duursma, S.A. Huisarts en specialist. Medisch Contact 1981; 7: $183-185$.

Duursma, S.A. Huisarts en specialist. Discussie: meer dan één model voor samenwerking. Medisch Contact 1981; 26: $795-796$.

E.D.C.M. Informatie Bulletin. Discussie over ECG-werkafspraak $1981 ; 4: 28$.

E.D.C.M. Informatie Bulletin. Werkafspraak ECG 1981; $4: 29$.

E.D.C.M. Informatie Bulletin. Werkafspraak leverfunctietests $1982 ; 3: 7-8$.

Eijk, J.Th.M.; Gubbels, J.W. Wetenschappelijk onderzoek in de huisartsgeneeskunde. Commissie Wetenschappelijk onderzoek N.H.G.: Utrecht 1983 .

Eisenberg, J.M.; Goldfarb, S. Clinical usefullness of measuring Prothrombin time as a routine admission test. Clinical Chem. 1976; $22: 1644$.

Eisenberg, J.M., Williams, S.V., Garner, L., Viale, R., Smits, H. Computer-based audit to detect and correct overutilisation of laboratory tests. Medical Care 1977; 15: 915-921.

Eisenberg, J.M. An educational program to modify laboratory use by house staff. Journal of Medical Education 1977; 52 : 578.

Eisenberg. J.M. Use of diagnostic services by physicians in community practice. Medical Care 1981-vol.XIX; 3: 297-309.

Es, J.C. van. Faculteit en eerste lijn. Medisch Contact 1981; 7 : 179.

Ea, J.C. van; Melker, R.A. de; Goosmann, F.C.L. Kenmerken van de huisarts II. Utrecht; Bohn, Scheltema en Holkema 1983.

Es, J.C. van. Protocollaire geneeskunde. Nieuw kompas voor de Huisarts juli. 1984; II; 4-1: 15 .

Es, J.C. van. Medische besliskunde. Medisch Contact 1984; 9: 263.

Es, J.C. van. Het Diagnostisch Centrum. Medisch Contact 1984; 12: 359.

Bs, J.C. van. Samenwerking huisartsen-specialisten. Medisch Contact $1985 ; 4: 87$.

Es, J.C. van. Rekenaars en protocollen. Medisch Contact 1985; 14: 411. 
Es, J.C. van. Huisarts, specialist en taken. Medisen Contact 1985: 15: 443 .

Es, J.C. van. Verwijzen. Medisch Contact 1985; 40: 1259.

Es, J.C. van. Het ziekenhuis geen middelpunt maar ook geen knelpunt van de zorg. Medisch Contact 1986; 1: 20-25.

Everwijn, S.E.M.; Melker, R.A. de. De werkwijze van huisarts en specialist. Huisarts en Wetenschap 1985; $9: 302$.

Experiment Diagnostisch Centrum Mastricht. Raamplan 1978.

Federspiel, C.F. Medical records a valid data source. Medical Care 1976-vol.XIV; 2:

Fernow, L.C., Mackie, C.. McColl, I., Rendall, M. The effect of problem-orientated medical records and clinical management controlled for patient risks. Medical Care 1978; 16: $476-487$.

Fowkes, F.G.R., Roberts, C.J. Introducing guidelines into clinical practice. Effective Health Care 1984; 6: 313-321.

Freeborn, D.K.; Baer, D.; Greenlich, M.R. et al. Determinants of medical care utilization. Physicians'use of laboratory services. Am. J. Public Health 1972; $62: 846$.

Gerritsma, J.G.M.; Smal, J.A. De werkwijze van huisarts en internist. Utrecht - Bunge 1982 .

Ghisel1i, E.E., Campbel1, J.L., Zedeck, S. Measurement theory for the behavioral sciences. San Francisco - Freeman 1981.

Gill, K. Protocollaire huisartsgeneeskunde; schijn van zekerheid? Huisarts en Wetenschap 1984; $27: 32$.

Goedhart, W.J.A., Knook, D.L. Geneesmiddelen en ouder worden. Alphen aan de Rijn: Stafleu 1980.

Greve, W. Samenwerking tussen ziekenhuis en eerste 1ijn. Medisch Contact 1982-juli; 28: 868-870.

Grimm, R.H., Shimonil, K., Harban, W.R., Estes, E.H. Evaluation of patient care protocol use by various providers. New England Jourmal of Medicine 1975; 292: 507-511.

Grinten, R. van de. Communicatje huisarts-specialjst. Medisch Contact $1981 ; 36: 777$.

Haan, M.C. den. Hulisarts en ziekenhuis. Huisarts en specialist III, discussi.e. Medisch Contact 1974; 29:675.

Hageman, H.J.; Giffen, H. van: Meyboom, W.A. Verslaglegging van specialist aan huisarts. Medjsch contact $1984 ; 16 ; 513$.

Hart, 0 . van der. Overgang en bestendiging; over het ontwerpen en voorschrijven van rituelen in de psychotherapie. Academisch proefschrift, Leiden 1978 .

Hartgerink, M.J. Diagnostische Centra. Medisch Contact 1974; 29 : 738 .

Heckman, J. De huisarts als spil in de gezondheidszorg. Huisarts en specialist IX, discussie. Medisch Contact 1974; 29: $880-882$.

Helm, H.J. van der; Hische, E.A.H. De evaluatie van aiagnostische technologieën. Medisch Contact 1986; 9: 273-276.

Hemminki, E. Review of literature on the factors afferting arug prescribing. Soc. Sci \& Med.; vol 9: 111-115.

Herschel, J.G.; Peters, J.H. "Hospital audit", een halibaar mode1. Medisch Contact 1978; 33: 1567.

Heyden, M.N. van der. De besluitboom in de heelkunde. Medisch Contact 1983; 21: 621. 
Hofmans, A.: Straten, W.S.J. Wan de; Bürkenhäger, W.H. Opsporing 1. schaemische hartziekten door middel van een electrocardiografische djenst voor huisartsen. Huisarts en wetenschap $1973 ; 16: 465$.

Hollenbeek-Brouwer, H. et al. Samenwerken moet je leren. 's-Graventiage 1981; Vuga.

Horikx, M.J. Takyerdeling le en 2 e echelon. Medisch Contact $1979 ; 769-772$.

Horst, $F$. van der. Konsultanalyse; structuur van en initilatieven in huisarts-patient gesprekken. Rapport in voorbereiding. Rj.jksuniversiteit Limburg.

Hull, C.H.; Nie, N.H. SPSS-update 7-9. McGraw Hill, New York 1981 .

Huygen, F.J.A.; Melker, R.A. de: Over het verwijzen door de huj.sarts. Medisch Contact 1973; 28: 1229-1302.

Huygen, F.J.A.; Melker, R.A. de; over het verwijzen door de hudisarts. Medisch Contact 1973; 28: 1299.

Huygen, F.J.A. Een visie op de gezondheidszorg vanuit de eerste 1.jn. Mossel DAA (red). Waarheen met onze gezondheidszorg. Amboboeken Baarn 1977.

Jacobs, H.M.; Touw-otten, mevr. F.W.M.M.; Melker, R.A. de. Taakopvatting en ziekerhuisbezoek. Huisarts en Wetenschap 1979: $22: 226-234$.

Jacobs, H.M.; Melker, R.A. de; Touw-Otten, mevr. F.W.M.M. Samenwerking tussen hujsarts en specialist. Medisch Contact $1983 ; 51: 1599$.

Jones, S.R., Barks, J., Bratton,T., McCree, E., Pannel, J., Yanchick, V.A., Browne, R., Smith, J.W., The effect of an educational program upon hospital antibiotic use. American Journal of Medical Science 1977; 273:79-85.

Jongerius, J.A.C. Samenwerking tussen huisarts en specialist. Medisch Contact 1985; 16: 491.

Joyce, D. What was prescribed. In: Treatment or diagnosis. A study of repeat prescriptions in general practice. Tavistock Publications Londion, 1970: 63.

Kastelein. A. Kiezen of delen, over de bruikbararheid van diagnostiek. Medisch Contact 1983; 24:721.

Keljsers, L.L.J.M., Konj.ng Gans, H.J. de. Communicatie tussen huisarts en specialist. Medisch Contact 1983: 29: 902-903.

Klecka, W.R. Diseriminant analysis. Sage University Paper 15, Beverly Hills 1980 .

Kolkman, H.H.E.: Voort, P.C.H, van der. Samenwerking huisarts specialjst. Medisch Contact 1985; 35: 1065 .

Kolkman, H.H.E.; Vissers, J. De lijnen bujten spel, structurering van de samenwerking tussen le en $2 e$ lijn. Medisch Contact $1986 ; 1: 11$.

Koning Gans, H.J.; Keljsers, L.L.J.M. Communilcatie tussen huisarts en specialist. Medisch Contact 1983; 38: 902 .

Koperberg, I.Ph.L. Voorschrijven. Medisch Contact 1980; 35; 454 .

Knottnerus, J.A. Principes van besliskunde. Uit: Nieuw Kompas voor de Huisarts 1984, juli; II/4-1/15.

Lamberts, H.; Wolgast, N.L. Huisarts en voorschrijfgedrag - een onderzoek naar het voorschrijven van geneesmiddelen. Huisarts en Wetenschap 1975; 18: 321 . 
Lamberts, H. Hoe beInvloedbaar is de huisarts? Huisarts en Wetenschap 1981; 10: 371 .

Lamberts, H. Redactioneel commentar: protocollen, normen en warden. Huisarts en wetenschap $1983 ; 26: 122$.

Lamberts, H. Het huis van de huisarts nu en straks. Amsterdam Heierman \& co. 1985.

Leerling, R.J. Een alternatieve "eigen bijdrage" discussie. Medisch Contact 1979; 34: 531 .

Leerling, R.J. Hoe stat het eigenlijk met de alternatieve ejgen bijdrage. Medisch Contact 1979: 34 : 548 .

Leijnse, B. Economische overwegingen bij de toepassing van medische technologieèn. Medisch Contact 1986; 4: 101-105.

L.H.V. Blauwdrukbeleid landelijke huisartsenvereniging 1975

L.H.V. De taken van de huisarts, rapport van de Commissie Takenpakket der Landelijke Huisartsen Vereniging. Medisch Contact $1977 ; 32: 765-789$.

L.H.V. Nieuwe blauwdruk. Medisch Contact 1977; 32: 973-977.

L.H.V. Functieomschrijving van de huisarts. Medisch Contact 1981; 36 : 1474-1476.

L.H.V. Samenwerking, een inventarisatje. Nora 1982 .

Loon, P.C.J. van. Wat wringt er in de erstelijns gezondheidszorg? Medisch Contact 1982; 16:473.

Lord, F.M., Novick, M.R. Statistical theories of mental test scores. Addison-Wesley, reading Massachusettes, 1.968.

Mansvelt, J. van. Suggesties ten aanzien van samenwerking tussen huisarts en specialist. Hulsarts en Specialist $V$, discussie. Medisch Contact 1974; 29: 734.

Mansvelt, J. van. Betekenj.s Diagnostisch Centrum voor de planningsfunctie van het college van ziekemhisvoorzieningen. Medisch Contact 1979; 41: 14-17.

Marinker, M. The doctor's role in prescribing. J. R. Coll. Gen. Practit. 1973; 23: 22 .

Martin, A.R., Woll, M.A., Thibodeau, L.A., Dzau, V., Braunwald, E. A trial of two strategies to modify the test ordering behaviour of medical residents. New England Journal of Medicine 1980; $303: 1330-1336$.

Melker, R.A. de. Knelpunten in de samenwerking hulisarts-specialist. Medisch Contact 1974; 35: 631.

Melker, R.A. de. Beterschap door beter beleid. Dekker en v/d Vegt, Nijmegen 1975 .

Melker, R.A. de. Het Diagnostisch Centrum: brug tussen ziekenhuiszorg en thuiszorg. Rede bij opening DCO, 15-05-1979. Medisch Contact 1979; 41: 23-26.

Melker, R.A. de. Gebruik van aiagnostische faciliteiten door de huisarts. Medisch Contact 1980; 35: 699."

Melker, R.A. de. Wat wringt er in de eerstelijns gezondheidszorg? Medisch Contact 1982; 25: 731 .

Melker, R.A. de. Diagnostische faciliteiten voor de huisarts: wie wordt er beter van? Huisarts en wetenschap $1983 ; 26: 184$.

Melville, A. Job satisfaction in general practice: implications for prescribing. Soc. Sci \& Med.; vol. 14A:495-499.

Metz, W. De relatie specialist-huisarts. Medisch Contact 1974; 29: 709 .

Meyboom, W.A. et al. Het voorschrijven van geneesmiddelen a ar kleine kinderen. Huisarts en Wetenschap 1984: 27:300-302. 
Meyboom, W.A. et al. Het voorschrijven van geneesmiddelen aan Kleine kinderen. Huisarts en wetenschap 1984:27: 303-305.

Mejjler, $F \cdot L$. Zekerheden en onzekerheden in de geneeskunde. Medisch Contact 1982; 7: 189.

Miler, R.R. Prescribing habits of physicians: a review of studies on prescribing of drugs parts IV-VI. Drug Intell. clin. Pharm. 1979; 13; 158.

Mintz, P.D., Nordine, R.B., Henry, J.B., Webb, W.R. Expected haemotherapy in elective surgery. New York State Journal of Medicine $1976 ; 76: 532-537$.

Nelson, A.R. Orphan data and the enclosed loop: a dilemma in PSRo and medical audj.t. New England Journal of Medicine 1976: $295: 617-619$.

MHG Hoe helpt de dokter? Utrecht, 1975.

NHI Holland naar de horizon. Utrecht 1979.

MHI/NZI Eindrapport Djagnostisch Centrum Oudenrijn.

NHI/NZI Huisarts en Diagnostisch Centrum. Mej 1982.

NHI Samenwerking in Hoogeveen. Utrecht 1982.

NHI Onderlinge toetsing in de huisartsgeneeskunde - tussentijase reportage - februari 1982 - februari 1983. Utrecht 1983 .

Nj.c, N.H.; Hul., C.H.; jenkjns, J.J.; Steinbrenner, K.; Bent, D.K. SPSS, second edition. MCGraw Hill, New York 1975.

Noether, G.E. Introduction to statistics. Houghton Mifflin, Boston 1976.

Noren, J.M.D. et al. Ambulatory medical care; a comparjson of juternists and family-general practitioners. New England Journal of Medicine 1980; vol $302 \mathrm{nr}$. 1: 11-16.

Nutting, P.: Shorr, G.; Burkhalter, B. Assessing the performance of medical care systems: a method and its application. Medical Care 1981-March-vol.XIX; 3: $281-296$.

Nijhuis, H.J. De relatie huisarts-specialist. Medisch Contact $1981 ; 52: 1617$.

Onderzoeksvoorstel Evaluatie Diagnostisch Centrum Ouderijn, definitieve versie. Nederlands Huisartseninstituut: Nationaal Ziekenhuisinstituut, Utrecht mart 1981 .

oosterhuis, W.W. De conmunicatieve watrde van correspondentie tussen de huisarts en de specialist. Huisarts en SpeciaL.s. XII, discussie. Medisch Contact 1974; 963-964.

Parish, p.A. Sociology of prescribing. Br. Medical Bul1. 1974; 214 .

Patterson, H.R., Fraser, R.C., Peacock, E. Djagnostic procedures and the general practitioner. J. Roy. Coll. Gen. Practit. $1974 ; 24: 237$.

Pel, J.Z.S. Over de invloed van de huisarts op het verwijspercentage. Medisch Contact 1975; 32: 988-990.

Peters, J.H.; Bree, J.H.M. van. Project samenwerking eerste en tweede lijn van het ziekenhuis ouderijn te utrecht. Medisch contact 1977; $17: 537$.

Peters, J.H. Samenwerking eerste en tweede lijn. Medisch Contact $1982 ; 22: 655-659$.

Peters, J.H. Samenwerking eerste en tweedelijnsgezondheidszorg. Bohn, Scheltema, Holkema, Utrecht 1982.

pineault, $R$. The effect of medical training factors on physician utilization behavior. Medical Care 1977; 15: 51. 
Pop, P. Consultatie eerste - tweede 1ijn. Medisch Contact 1982; 34: 1019-1023.

Pop, P. Endoscopisch onderzoek door de huisarts. Drie jaar Diagnostisch Centrum Maastricht. Medisch Contact 1982; 37: 1125 .

Pop, P.: Kerkhof, P.D. Diagnostisch Centrum Maastricht (eindevaluatie van een experiment). Medisch Contact 1984; 24: 749 .

Pop, P.; Keijsers, L.L.J.M. Communicatie tussen huisarts en specialist. Medisch Contact 1985; 7: 203.

Post, D. Verwijzen. Medisch Contact 1983; 46: 1453-1456.

Post, D. Verwijzen in de perceptie. Medisch Contact 1984; $1 ; 19$.

Post, D. Verschuiving van tweede naar eerste lijn. Medisch Contact $1985 ; 13 ; 387$.

Prins, A. Drempelverlaging tot gebruik van laboratoriumfaciliteiten door de huisarts. Huisarts en Wetenschap 1976; $252-254$.

puijlaert, F.W.J. Versterking van de eerste lijn door raadplegen van de diagnost. Medisch Contact 1978; 33: 1134 .

puijlaert, F.W.J. Versterking van de eerste 1 ijn door raadplegen van de diagnost II. Medisch Contact 1978; 33: 1176.

Pujjlaert, F.W.J. "Taakverdeling le en 2 e echelon. Raadplegen van de diagnost in méér dan ziekenhuisfaciliteiten voor de huisarts. Medisch Contact 1979; $997-998$.

Pujjlaert, F.W.J.; Diederj.ck, M.C.I.M. Het raadplegen van de diagnost. Huisarts en Wetenschap 1979; $22: 192$.

Raat, H.; Gondriaan, G. Kwaliteitssysteem en professionele autonomie. Medisch Contact 1985; 27: 806.

Ramsay, J. Participants in noncompliance research: compliant or noncompliant? Medical Care 1982-vol.XX; 6: 611-622.

Raupp, J.L.M. Over werkwijzen van huisartsen. Dissertatie Nijmegen 1971 .

Ray, W.A. Prescribing of tetracycline to children less than 8 years old. JAMA 1977; 237: 2069-2074.

Rhyne, R.L., Gehlbach, S.H. Effects of an educational feedback strategy on physician utilisation of thyrojid function panels. Journal of Family Practice 1979; 8: 1003-1007.

Ris, B.G.M.; Diederiks, J.P.M. Een kritische analyse van interdisciplinaire samenwerking in de hulpverlening. Nederlands Tijdschrift voor Preventieve Geneegkunde TNO 1973-sept.

Ris, B.G.M.; Diederiks, J.P.M. Een kritische analyse van interdisciplinaire samenwerking in de hulpverlening. Tijaschrj.ft Sociale Geneeskunde 1974; $52: 553$.

Roberts, C.J., Evaluation of diagnostic services. In: Holland WW. Evaluation of Health Care. Oxford/New York/Toronto: Oxford University Press 1983.

Rop, H.J.; Lamberts, H.; Weel, C. van. Huisarts en verwijsgedrag. Huisarts en Wetenschap 1979; 22:306.

Rose, H.; Abel-Smith, B. Doctors, patients and pathology. Occasional papers on Social Adminjstration No.49. Bell and Sons, London 1972 .

Ruhe, H.A.M. Over de verwijzingsgewoonten in de huisartspraktijk. Huisarts en Wetenschap 1967; 10: $281-287$. 
Rutten, G.: Eijk, J. van; Beek, M. Huisartsen en gynaecologen over takafbakening en zelfzorg. Medisch Contact 1985; 14: 432.

Sang-o-Rhee, Ph. D. Influence of dient/collegue dependence on physiofar performance in patient care. Medical care 1980-WOL.XVIII; 8 :

Sanzaro, P.J. Medical audit. Experience in the U.S.A. British Medjoal. Journal 1974; $1: 271-274$.

Sanzaro, P.J., Worth, R.M. , Concurrent quality assurance in hospltal care. New England Journal of Medjcine 1978; 298: $1171-1177$.

Schets van de Eexstelijingezondheidszorg, Staatssecretaris van VOMIL. Staatsuitgeverij, 's Gravenhage 1980.

Schilperoort, J. De toepasbaarheid van electrocardjografische diagnostjek in de hujsartspraktjjk. Rjjksunjversjtejt Utrecht, Utrecht 1979 .

Sehipper, G.A. De diagnostische mogelijkheden van de huisarts. Medisch Contact $1973 ; 26-28$.

Schroeder, S." Showstack, J. Financial incentives to perform medjcal procedures and laboratory tests. Medjcal care 1978-Vol.XVI; $4: 289-298$.

Sjps, A.J.B.I. Protocollen voor de hui.arts. Medisch Contact 1986; 9: $277-279$.

Sisson,J.C., Schoomaker, E.B." Ross, J.C. Clinical decision analysis: The hazard of using additional data. Jama 1976; $236: 1259-1263$.

Snellen, H.A. Practische cardiollogje voor de hujsarts. Amsterdam: De Erven Bohn b.v. 1974 .

Soeren, F. Van. Help, de patient verzuipt.... (D.C. ziekenhuis Oudenrijn ambivalent experjment). Medisch Contact 1979; 38: 1212 .

staveren, G. van. Taakopvatting en werkwijze bij huisartsen. Ansterdam: VU-uj.tgeverj.j 1984.

stolte, J.B. Hujsarts en specialist in de samenleving. Hujsarts en specialist VII, discussie. Medisch Contact 1974; $812-814$

Structurnota Gezonaheidszorg, Staatssecretaris van VoMIL. Statsuj.tgeverj.j." s Gravenhage 1974 .

Sturmans, F. Arkel, W.G. van. Epidemiologie en planning van gezondhejaszorgvoorzieningen. Medisch Contact 1982; 20: 610, 22: 670, 38: 1200. artikelenreeks.

Sturmans, F. Is de gezondhejdszorg beheersbar? Medisch Contact $1985 ; 14: 417$.

Swinkels, M.A.A.: Dophejde, J.P. Samenwerking tussen eerste en tweede 1.jns gezondheidszorg te Hoogeveen. N.H.I., Utrecht 1982 .

Swinkels, M.A.A.; Lodewj.ck, L. Samenwerking huisartsen en specia1.isten. Medisch Contact 1985; 41: 1283 .

Symposium Werkverdeling tussen le en 2 e echelon. Symposium van Rotterdamse huisartsen en specialisten. Medisch Contact $1979 ; 742$.

Symposjum Huisarts en specialjst op éen lijn! Verslag sjnt Gregarius Ziekenhuis te Brunssum 1984 .

Tabachnick, B.J.; Fidell, L.S. Using multivarjable statjstücs. Harper and Row, New York 1983. 
Thiadens, A.J.H. Arts en patient; collega. Huisarts en Specialist VII, discussie. Medisch Contact 1974; $26: 861-864$.

Tielens, V.C.L. Hujsarts en specialist in dienst van de patient. Huisarts en Specialist $I$, discussie. Medisch Contact 1974 19: $589-591$.

Tukey, J.W. Exploratory data analysis. Addison-Wesley, Reading Massachusetts 1977 .

Velden, H.G.M. van der. Diagnose of prognose, de betekenis van epidemiologie voor het handelen van de huisarts. Hujsarts en Wetenschap 1983; 26: 125 .

Vissers, T.C.G.M. Strategjeën om een ongebrejdelde groej van medische technologië̈n te voorkomen. Medisch Contact 1986 : 4: $105-110$.

Volksgezondhejasnota, Ministerie van Socjale Zaken en Volksgezondheid. Staatsuitgeverij 's Gravenhage 1966.

Vorst, F"A. Eerstelijnszorg en structuur. Medjsch Contact 1985: 45: 1393 .

Wagner, E.H., Greenberg, R.A., Imrey, P.B., Williams, C.A., Wolfe, S.H. Ibrahim, M.A. Influence of trainjing and experience on selecting criteria to evaluate medical care. New England Journal of Medicine 1976; 294: 871-876.

Wjliamson, J.W., Alexander, M., Miller, G.E. Continuing education and patient care research. Physician response to screening test results. Journal of the American Medical Association $1967: 201$ : $938-942$.

Wolff, S. The social responsibility of the physician in prescribing mjnd-affecting drugs. In: Social aspects of the medical use of psychotropic drugs. Addition research Foundation of Ontario, Toranto 1974 .

woude, G.J. van der. Het zinloze ECG of: hoe gaan we om met overwaardering van medisch handelen. Nederlands Tijdschrift voor Geneeskunde 1980; 30 .

Wulff, H.R. Princjpes van kljnj.sch denken en handelen. Bohn, Scheltema, Holkema, Utrecht 1980.

Wijkel, D.; Grijn, D. van de. Huisarts en Diagnostisch Centrum. NZI/NHI, Utrecht 1982 .

Wijkel, D.; Grijn, D. van de. Diagnostisch onderzoek door huisartsen in ziekenhuizen. Medisch Contact 1983; $38: 373$.

Young, D.W. An aid to reducing unnecessary investigations. British Medical Journal 1980; 281: 1610-1611.

Zee, J. van der. De vraag naar diensten van de huisarts. Rotterdam: HOI-studio b.v. 1982 .

Zilnio, $R$. The interaction among the criteria physicians use when prescribing medical care. Medical Care 1982-vol. Xx; 3.

Zutphen, W.M. van. De taken van de hujsarts. Maastricht: RLdruk-reprografie 1984 . 


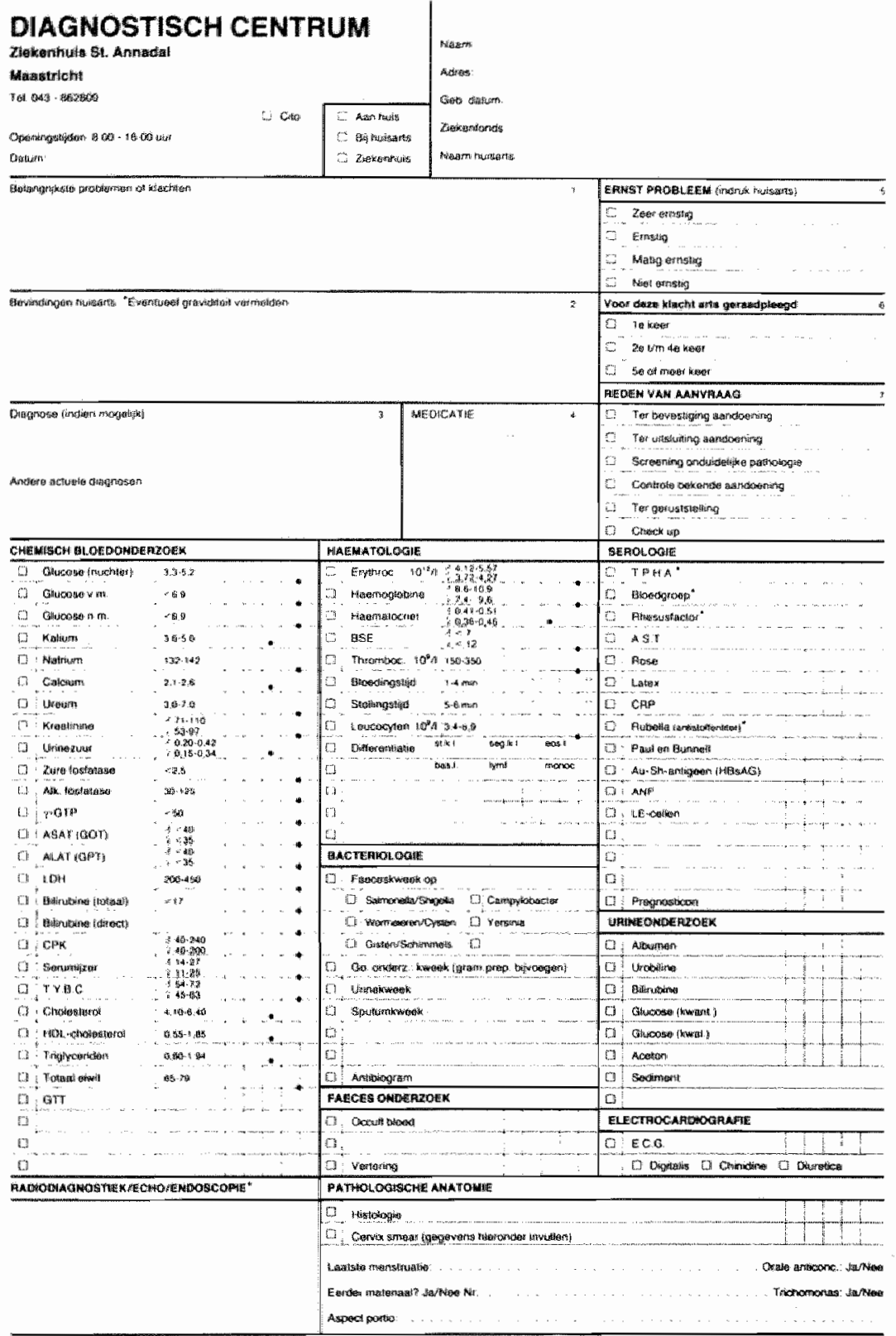




\section{DIAGNOSTISCH CENTRUM}

MAASTRICHT, 9 MEI 1983.

Zielkenhuis St. Annadal

Marastricht

Tel. $043 \cdot 862800$

U treft hierbij een wragenlijst aan waarin Uw mening wordt gevraagd over het Diagnostisch Centrum Maastricht en een aantal zaken dat daarmee verband houdt.

Een eindrapportage over het Experiment Diagnostisch Centrum Maastricht zou onvolledig zijn als de ervaring, die U als huisarts - gebruiker gedurende 4 jaar hebt opgedaan met deze voorziening, er niet in verwerkt was.

Aangezien het de bedoeling is het Diagnostisch Centrum voort te zetten en wit te breiden tot een coördinerend Centrum eerste - tweede lijn, hebben we bij het samenstellen van deze enquête aok naar de toekonst gekeken. Een aantal vragen is daarom cericht op analyse wan faktoren welke van invloed zijn op toepassing van een aantal werkafspraken.

Deze uitbreiding van de evaluatie wordt uitgevoerd door een medewerker van de capaciteitsgroep Huisartsgeneeskunde.

In verband daamee is de omvang van deze enquete zodanig dat met het invullen ongeveer drie kwartier gemoeid zal zijn. Wij raden $U$ aan halverwege, bijvoorbeeld na bladzijde 14 , in eerste instantie te stoppen om op een later tijdstip weer met meer positief gerichte aandacht door te kunnen gaan.

We stellen het bijzonder op prijs als U binnen 2 weken (vöör 28 mei a.s.) de enquête zou beantwoorden en terug sturen in de bijgevoegde envelop.

Bij voorbat dank voor Uw te memen moeite,
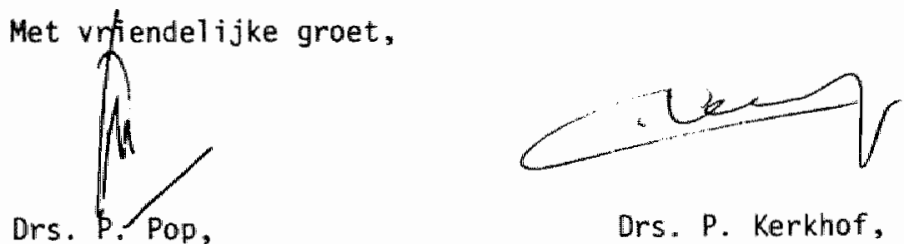

Drs. P. Kerkhof, 


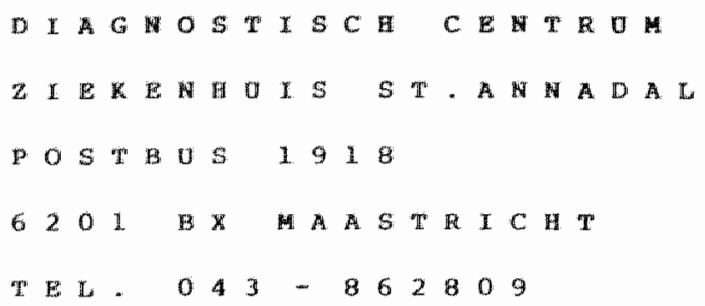

MADSTRICHT, APRIL 1984

Geachte collega,

Medio 1983 werd v vanut het

Diagnostisch Centrum een vragenlijst toegezonden, waran uw mening werd gevragd over het Diagnostisch Centrumastricht. in de eindrapportage over het experiment plagnostisch centrum. Mastricht werden deze enquete-gegevens werwerkt. Aangezien gepland werd het Diagrostisch centrum voort te zetten, werd bij het samenstellen van bovengenoemde wragenlijst ook naar de toekonst gekeker. Een antal vragen was in verband hiermee gericht op analyse van factoren die van invioed zijn op de toepassing van een aantal werkafspraken. Ten behoeve van deze ewaluatie is het noodzakelijk nog enige aanvullende informatie van 0 te verkrijgen. Een kort interview van +10 minuten zal. hierwor voldoende zijn. De Heer M. de Jong, onderzok-medewerker. zal zich in de eerste helft van de maand mei telefonisch tot o wenden on een afspratu te maken.

Wij stellen het bijzonder op prijs indien $U$, evenalls an de beantwoording wan bovengenoemde enquête, aan dit interview Uw medewerking zoudt willen verlenen.

Met vriendelijke groet.

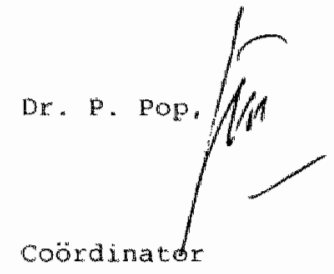

Diagnostisch centrum.

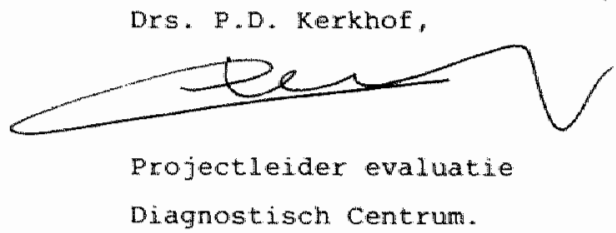


REDENEN OM DE WERKAFSPRAKEN IN COACRETE SITUATIES NIET TOE TE

PASSEN VAN TWAALF HUISARTSEN MET EHN HOGE TOEPASSINGSSCORE.

1: - vergeten

- druk patient

- druk controlerende instantie (GAK)

- privacy van de patient (Go, alcohol)

- bij patient die je weinig ziet vraag je meer aan

- er moet een werkafspraak voor check-up konen.

2: - vergeten

- andere eveneens gemaakte werkafspraken interfererend met deze werkafspraak (bv " binnen gezondheidscentrum)

- tijdsdruk

- ten gevolge van onvolledig invullen

3: - vergeten

- tijdsgebrek

- beperkt invullen tekst formulier

- druk patient

- behcefte aan werkafspraak voor cheque-up

4: - druk van de patient

- werkafspraak niet bij de hand (ken hem niet uit het hoofd)

- bij onbekende patjent wordt meer gewikt

- rond "kern' zaak meer aanvragen

5: - tijosdruk

- slordigheid

6: $\quad$ - tijdsdruk

- onwetendheid

7: - tijdsdruk

- geruststelling patient

- druk patient

- ernstige pathologie heeft ten gevolge dat je meer aanvraagt

- niet alles past in werkafspraak

- feedback op werkafspraak gewenst

8: - onwetendheid

- tijdsaruk

- oude routine

9: - geheimhouding voor de patient

- bij combinaties van het aanvragen

- bij controle van ẽên zaak iets anders even mee aanvragen

10: - druk patient

- op verzoek van bv. een sportarts (ECG)

11: - tijdsdruk

- geruststelling patient

- druk van de patient

- bij ernstjige pathologie vaak meer aanvragen

- geen controle op werkafispraak nakcmen

12: - multipele pathologie, werkafspraak moeilijk op te volgen

- tijdsaruk

- vage ziektebeelden

- privacy

- ziektebeelden die niet onder de werkafspraak vallen 
1: - ongeduld

- teveel werkafspraken waardoor ze moeilijk te hanteren zijn

- werkafspradk is slechts richtlijn!

2: - onbekendheid met de werkafspraak

- druk van de patient (met name bij EOG)

- routinematig handelen (bij alat altjjd asat)

3: - druk van patient

- privacy patient (alcohol)

- vroegere gewoonte om afwijkende bevinding nog eens te checken

4: - moet nog wennen aan de werkafspraak

- onwetendheid

- tj.jdsanuk

5: - slordigheid

- ECG ter geruststelling

- niet alles in werkafspraak te vangen

6: - slordigheia

- ti.jasgebrek

- oude patronen (alat bij asat)

7: - vergjissen

- tj.jasdruk

- routine (bij leverfuncties vaak teveel)

- werkafspraak met andere instantie (bv CAD)

8: - vergeten

- bj.j onduj.deli.jke pathologie wordt meer aangevraagd

- vermeld alcohol vaak niet op formulier

9: - privacy van die patient

- op verzoek van de patient

- vergeten

- voor leverfunctietesten vast rijtje, vaste routine

10: - vage klachten (daar is het Diagnostisch Centrum juist voor)

- past niet in allie hokjes (werkafspraak is beperkt)

- privacy (alcohol)

11: - geruststelling patient

- tijasaruk.

12: - onbekendheid met de werkafspraak

- tijdsdruk

13: - creatief vrjij denken moet mogelj.jk $\mathrm{zij}$.jn

- niet alles is in de werkafspraak te vangen

- druk vanuit de patient

- bij systeemziekte wil je meer aanvragen 
Dankbetuiging.

Dit onderzoek heeft plaatsgevonden onder de huisartsen van Maastricht en omgeving, die samenwerken met het Diagnostisch Centrum en een referentiegroep van Nederlandse huisartsen. De gegevensverzameling geschiedde vanuit dit Centrum "waarvoor ik de coörajnator Dr.P. Pop, de lejder van de projectgroep evaluatie E.D.C.M. Drs. P. Kerkhof en de beheerder van het Centrum $\mathbb{P}$. Reinjers, veel dank verschuldigd ben. Eveneens ben ik zeer erkenteljjk voor de belangeloze medewerking van de hujsartsen, zonder wiens medewerkjng dj.t onderzoek niet mogeli.jk was geweest.

De basale verwerking van de gegevens was mogeljjk met de hulp van R. Henquet, P. Hulshof en J. Nijhof. Dankzij M.L. Coenen-Boers konden de gegevens in de computer worden ingevoerd. De verwerking in eerste instantie geschledde door J. Roos.

Bij de verdere statistische analyse was voor mij de hulp van Dr.R. Does van cruciaal belang. Ditzelfde geldt voor M. de Jong, die als student-assistent mij het grootste deel van het onderzoek behulpzaam was.

In het bjjzonder wil ik mjjn promotor Prof.Dr.W. Brouwer danken voor zijn continue inspiratie en steun. De krj.tische bemerkjngen van de referenten Prof.Dr.J. Bremer, Prof.Dr.R. de Melker, Prof.Dr.H. Philipsen en Prof.Dr.F. Sturmans hebben mij mede gejnspireerd tot de uj.teindeljjke vormgeving van dit proefschrift.

zeer bjjzonder dank ben ik verschuldjgd aan G. Seegers, die in staat bleek het concept manuscript en alle correcties nauwgezet te verwerken.

Voor de Engelse vertaling van de samenvatting dank ik tenslotte G. Veenstra. 


\section{Currjeulum Vitae.}

De auteur werd op 3 augustus 1944 te Noorbeek geboren. Na zijn middelbare schoolopleiding, deels aan het klein-seminarie Rolduc te Kerkrade en deels aan het Henric van Veldeke College te Maasticht, studeerde hij van 1963 - 1971 geneeskunde an de Katholieke Universitejt te Nijmegen.

In 1971 was hij als huisarts werkzam in de praktijk van Drs.J.Deumens te Posterholt. Van eind 1971 tot begin 1973 volgde hij de oplejding Chirurgie bij Dr.A. Knapen in het Sint Jozef Zlekenhujs te Eindhoven. In 1973 en 1974 was hij tegeljjkertjjd werkzaam als hussarts in de praktjjk van Drs.M.J. Botman te Herkenbosch en als medisch directeur in het verpleegtehuis Sint Camjl1us te Roermond.

Eind 1974 vestigde hij zich als huisarts in Maatricht in associatie met Drs.W. Vierhout. Vanaf 1977 werd de associatie voortgezet in het gezondheidscentrum "De Hofhoek" te Mastricht.

Sinds 1975 is hij als wetenschappeljjk medewerker part-time verbonden aan de capacitejtsgroep Huisartsgeneeskunde (Hoofd Prof.Dr.W. Brouwer) wan de Rijksuniversiteit Limburg te Mastricht. Hij is vooral betrokken bij de opzet van het basiscurriculum en de vormgeving van een nieuw nascholingscurriculum voor hujsartsen. 